\title{
A presença e a ausência dos rios de São Paulo: acumulação primitiva e valorização da água
}

\author{
José Paulo Neves Gouvêa \\ Orientador Angela Maria Rocha
}

Tese apresentada à Faculdade de Arquitetura e Urbanismo da Universidade de São Paulo para a obtenção do título de Doutor em Arquitetura e Urbanismo

Área de Concentração

Tecnologia da Arquitetura

São Paulo, 2016 
AUTORIZO A REPRODUÇÃO E DIVULGAÇÃO TOTAL OU PARCIAL DESTE TRABALHO, POR QUALQUER MEIO CONVENCIONAL OU ELETRÔNICO, PARA FINS DE ESTUDO E PESQUISA, DESDE QUE CITADA A FONTE.

e-mail:paulogou@uol.com.br

Gouvêa, José Paulo Neves

G719p A presença e a ausência dos rios de São Paulo: acumulação primitiva e valorização da água / José Paulo Neves Gouvêa. -São Paulo, 2016.

240 p.:il.

Tese (Doutorado - Área de Concentração: Tecnologia da Arquitetura) - FAUUSP.

Orientadora: Ângela Maria Rocha

1.Produção do espaço 2.Água (Produção) 3.Infraestrutura urbana (Produção) 4.Urbanização (Aspectos sociopolíticos; Aspectos socioeconômicos) 5. Privatização do espaço 6.Rios urbanos I.Título 
A presença e a ausência dos rios de São Paulo: acumulação primitiva e valorização da água

José Paulo Neves Gouvêa

Tese apresentada à Faculdade de Arquitetura e Urbanismo da Universidade de São Paulo para a obtenção do título de Doutor em Arquitetura e Urbanismo

APROVADO EM:

BANCA EXAMINADORA:

PROF. DR.:

INSTITUIÇÃO:

ASSINATURA

PROF. DR.:

INSTITUIÇÃO:

ASSINATURA

PROF. DR.:

INSTITUIÇÃO:

ASSINATURA

PROF. DR.:

INSTITUIÇÃO:

ASSINATURA

PROF. DR.:

INSTITUIÇÃO:

ASSINATURA 

para juntar Lelê e Sebá

que por pouco não se conheceram

pois ela chegou logo depois que ele partiu 

à minha orientadora Angela Rocha pela dedicação desde o mestrado e pelos anos de diálogo atento.

à FAUUSP.

à Marisa Ohashi pelo apoio incondicional em todos os momentos. especialmente à minha mãe Vera por estar sempre presente.

aos meus irmãos João, Bel e Paula.

aos meus sogros Yolanda e Luiz Antonio.

à Jorge Hajime Oseki pela presença na ausência.

à Paulo Cesar Xavier Pereira e Amélia Damiani pela leitura crítica e atenta e por mudar o rumo da pesquisa no momento certo.

aos amigos José Eduardo Baravelli, Guilherme Petrella e Catherine

Otondo, pela ajuda fundamental em momentos importantes e pela opinião sincera.

aos amigos Rafael Urano, Guilherme Pianca e Alexandre Benoit, avante. aos amigos Daniel Trench e Celso Longo, mais uma vez.

aos amigos Roberto Guedes e Maíra Martinez.

aos amigos do escritório Denis Ferri, Marcelo Madalozzo, Maria Wolf

e Luiza Andrade pelo apoio fundamental.

aos amigos, Beatriz Tone, Luciana Ferrara, Renata Moreira e Taís

Tsukumo e Vinícius Spira, Andrea Flores Urushima, João Sodré, Julia-

na Braga, Cícero Ferraz Cruz, Pablo Hereñú, Sebastian Beck, Giovanni Meirelles e Eduardo Ferroni.

à Escola da Cidade, especialmente à Ciro Pirondi, Álvaro Puntoni e Anália Amorim, Anderson Freitas e Fábio Valentim.

aos amigos Jorge Pessoa, Marina Grinover e Luis Antonio Jorge.

aos amigos José Armênio Brito Cruz, Renata Semin, Marcos Aldrighi e

João Paulo Beugger.

aos amigos e professores Antonio Carlos Barossi, Alexandre Delijaicov, Helena Ayoub Silva e Marta Bogéa.

aos professores Zilda Iokoi, Luiz Guilherme Galeão e Sérgio Bairon.

aos funcionários da secretaria e da biblioteca da FAUUSP.

ao Museu Paulista, ao Arquivo Público do Estado de São Paulo, à Fundação Biblioteca Nacional.

à Bilblioteca Vilanova Artigas e à Gráfica Flávio Motta.

à Biblioteca Florestan Fernandes, à Biblioteca Mário de Andrade. 
A presença e a ausência dos rios de São Paulo: acumulação primitiva e valorização da água

A presente tese analisa o processo de apropriação privada dos rios de São Paulo e sua participação na produção do espaço da cidade, aprofundando aspectos relativos ao desenvolvimento social, político e econômico, desde sua fundação no século XVI até o início do século XX. Partindo das obras de canalização dos rios Tamanduateí, Tietê e Pinheiros, a pesquisa realiza um recuo histórico até o momento em que os rios e córregos de São Paulo se constituíam como um bem comum e sua principal característica era o uso de suas águas e terras. As diversas atividades relacionadas aos rios e córregos, nos primeiros séculos da ocupação, caracterizam-se pela convivência entre o consumo imediato, a utilização de mão de obra cativa e a obtenção de renda através do trabalho livre, em um momento em que a economia de São Paulo era tímida e a poluição dos rios já era percebida. Durante o século XIX, a partir da cultura do café e da imigração, estabeleceu-se uma economia baseada no trabalho livre assalariado e na valorização da propriedade fundiária. Na cidade de São Paulo, o crescimento populacional e a insuficiência da distribuição de água e esgotamento, associados ao significado econômico da propriedade e a disponibilidade de mão de obra, passaram a representar a possibilidade de valorização do capital a partir do estabelecimento de condições gerais de produção. Os rios de São Paulo foram então incorporados ao processo de provisão de infraestruturas e redes de serviços urbanos. Esse processo de acumulação de riqueza, baseado na expropriação da terra e da água, transformou os rios de São Paulo em recursos econômicos e engendrou um espaço que se caracteriza pela sobreposição do domínio particular sobre o domínio comum.

PALAVRAS-CHAVE

produção do espaço, água (produção), infraestrutura urbana (produção), urbanização (aspectos sociopolíticos; aspectos socioeconômicos), privatização do espaço, rios urbanos. 

The presence and absence of the rivers in São Paulo: primitive accumulation and water appreciation

The present theses analyses the process of private appropriation of the São Paulo city's rivers, and its role in the production of space, developing the social, political and economical aspects since the early 16th century until the beginning of the zoth. Beginning by the channelling works at the Tamanduateí, Tietê and Pinheiros rivers, this work presents a historical research since the point in time when the city's rivers and streams were considered a common good and its main feature was the use of its water and the riverbanks. The several activities related to the use of rivers and streams, in the early centuries of occupation, are characterized by the coexistence of immediate consumption, the use of slave labor and the work of free man. At that time, the São Paulo economy was weak and the pollution of rivers began to be an issue. During the 19th century, coffee production and immigration enhanced, and an economy based on wage labour and appreciation of land property was settled. In Sao Paulo, the population growth, the insufficient water and sewage supply, associated with the labour supply and the economic value of land property, provided the possibility of capital increase through the establishment of production conditions. The rivers of São Paulo were incorporated in this process of provision of urban infrastructure. This process of wealth accumulation, based on land and water expropriation, turned the rivers into economic resources and generated a space characterized by the predominance of the private over the common domain.

\section{KEYWORDS}

production of space, water (production), urban infrastructure (production), urbanization (social, political and economical aspects), privatization of space, urban rivers. 

ÍNDICE

INTRODUÇÃO - P. 15

PARTE I - USO DA ÁGUA, SUBSISTÊNCIA E TRABALHO - P.45

CAPÍTULO 1 - BEM COMUM, ÁGUA E TRABALHO - P.47

CAPÍTULO 2 - TRABALHO LIVRE, PRIMEIRA REDE E CHAFARIZES: LUTAS PELO CONTROLE E POSSE INDIVIDUAL DA ÁGUA - P.71

CAPÍTULO 3 - SUBSISTÊNCIA PELO RIO: PESCA, AGUADEIROS, LAVADEIRAS E A RENDA DA ÁGUA - P.95

PARTE II - APROPRIAÇÃO DA TERRA, DO HOMEM E DA ÁGUA - P.113

CAPÍTULO 4 - APROPRIAÇÃO DO BEM COMUM - P.115

CAPÍTULO 5 - APROPRIAÇÃO DA ÁGUA - P.159

CONCLUSÃO - O RIO TORNADO ÁGUA - P.211

REFERÊNCIAS BIBLIOGRÁFICAS - P.225

LISTA DE IMAGENS - P.235 

INTRODUÇÃO

As preocupações que fundamentaram a presente pesquisa têm origem na observação da relação dos rios de São Paulo com a ocupação do seu entorno imediato, suas várzeas e planícies aluviais urbanizadas. No caso dos rios Tamanduaté, Tietê e Pinheiros, rios que estruturam a cidade, sua canalização e as rodovias instaladas em suas margens garantem sua ausência e completo isolamento no contexto da cidade sendo notados apenas em momentos críticos como em enchentes e transbordamentos. A maior parte dos córregos da cidade foi tampada, permanecendo ignorada pela maior parte da população. Rios que ocupam uma posição importante na cidade permanecem como canais de esgoto a céu aberto, em absoluto contraste com a ocupação de suas margens.

Essas observações levaram ao questionamento de quais seriam os processos que levaram esses rios a estabelecer tão desprivilegiada condição no contexto urbano de São Paulo, permanecendo, atualmente, presentes como rede de esgotos e drenagem e ausentes como recurso natural.

O estudo do processo de dominação dos rios e córregos de São Paulo permite colocar que, a partir de uma condição de bem comum, quando sua principal característica era o uso de sua águas e suas terras (várzeas), esses recursos foram lentamente incorporados ao processo de obtenção de renda para subsistência e, posteriormente, com o desenvolvimento 
do modo de produção capitalista, valorização do capital. Esse processo fez com que os rios e córregos, de recursos naturais se tornassem recursos econômicos, implicando a estruturação do espaço da cidade e a forma com que foram urbanizadas suas terras e apreendidas suas águas.

Atividades imediatas de subsistência relacionadas aos rios passaram, desde os primeiros anos da colonização, a ser intermediadas por trabalho escravo negro e indígena, passando também a possibilitar a obtenção de renda em dinheiro, transformando a relação entre produtor direto e meios de produção.

A partir da cultura do café e do estabelecimento de uma economia baseada no trabalho livre assalariado e da valorização da propriedade fundiária, os rios de São Paulo foram incorporados ao processo de provisão de infraestruturas e redes de serviços urbanos que visavam o estabelecimento de condições gerais de produção.

No contexto do início da industrialização e intensa imigração, com consequente crescimento da população e da área urbanizada, essas provisões, além de necessárias ao saneamento e à distribuição da água, visavam principalmente a valorização do capital investido nessas obras, não somente através da exploração da mão de obra e venda dos produtos, mas também a partir da valorização da propriedade territorial proporcionada por essas infraestruturas. Esse processo de separação dos rios entre terra e água, isto é, de constituição desses elementos como mercadorias, está vinculado ao processo de acumulação primitiva do capital e baseado na produção do espaço, revelando contradições estruturais da urbanização de São Paulo ao contrapor um recurso essencial à vida a interesses econômicos.

Pensar a produção do espaço implica considerar o espaço como produto social, ou seja, considerar o espaço, assim como o tempo, não mais como fato da "natureza" ou simples fato da "cultura", mas como produto. Entretanto, esse produto-espaço não é um objeto, uma coisa, mas um conjunto de relações. Segundo Jorge Oseki, esse espaço "não é passivo nem vazio, não tem a troca e o consumo como única finalidade e sentido, como se dá com outras mercadorias". Ele não deve ser confundido com as mercadorias comuns, entendido apenas como resultado do trabalho abstrato. Esse espaço não pode ser concebido como tendo

1. OSEKI, Jorge H. O Único e o Homogêneo na Produção do Espaço in MARTINS, José de Souza (org.). Henri Lefebvre e o retorno à dialética, São Paulo: Hucitec, 1996. cit. p. 111. 
apenas o sentido, como outros 'produtos', da troca, do ser consumido, do desaparecer. (OSEKI, 1996, p. 111) O espaço como produto intervém na produção social, na organização do trabalho, no fluxo e no estoque de matérias primas e energia e nas redes de distribuição. É, portanto, produto-produtor. "O produto torna-se produtivo, passando pela extrema abstração" . (LEFEBVRE, 2007, p. 3 ) O espaço participa, portanto, tanto das forças produtivas como das relações de produção e propriedade, da realização e da repartição da mais-valia.

Os rios de São Paulo devem ser entendidos como um produto social, resultado da produção do espaço, mas também agente dessa produção. Os rios são entendidos, portanto, não mais como somente um objeto da natureza e da sociedade, mas sim como um elemento gerador de usos e trocas, de sociabilidades e disputas; de construção e destruição de espaços; de conflitos e de satisfação das necessidades do corpo; e, sobretudo, inserido no contexto da urbanização, gerador de valor.

Nesse sentido, o começo do século XX foi decisivo para a urbanização dos rios de São Paulo, pois o Tamanduaté́, o Tietê e o Pinheiros foram canalizados, suas margens foram urbanizadas e incorporadas ao tecido urbano e suas águas passaram a integrar as redes de esgoto e drenagem. Grandes planos urbanísticos norteavam a produção do espaço da cidade sendo responsáveis por reafirmar a necessidade de ocupação das várzeas com a promoção de loteamentos e a implantação de avenidas ${ }^{3}$, configurando uma fase de intervenções físicas nos rios de São Paulo. A mudança de foco da economia da cafeicultura para a indústria urbana, no final dos anos 1920, e a consolidação do sistema ferroviário estimularam a tendência de se ocupar as planícies que circundavam a cidade e as várzeas dos rios com instalações industriais. Esse processo consolidou a supressão das várzeas e a impermeabilização do entorno direto dos rios e, assim, intensificou o número e o volume de enchentes em São Paulo.

Esse processo foi marcado pela maciça presença de companhias de urbanização, que se instalavam no Estado de São Paulo e começavam

2. LEFEBVRE, Henri. A Produção do Espaço. prefácio da edição francesa de 1974, tradução de Jorge Hajime Oseki, mimeo, 2007, p3.

3. Segundo Jorge Oseki a construção das avenidas de fundo de vale configurou uma transformação dramática na espacialidade da cidade, já que uniam loteamentos antes separados por córregos e propiciavam um grande fluxo de pessoas e transporte pelos antigos rincões dos rios paulistanos. (OSEKI, ESTEVAM, 2006) 
a fornecer serviços urbanos. Empresas como a Companhia. Cantareira $\mathcal{E}$ Exgottos, a Companhia Água e Luz, Pucci \& Minelli, a City of São Paulo Improvements and Freehold Land Company Ltd, a Cia de Viação Paulista e a São Paulo Tramway Light $\&$ Power Co Ltd, entre outras, introduziram novos componentes de ordenação do espaço, sempre visando a reprodução do capital. Cada um dos serviços de água, luz, esgoto, telefone e transporte, foi então produzido por uma empresa seguindo seus próprios interesses, impossibilitando qualquer hipótese de ação conjunta. ${ }^{4}$

\section{A CANALIZAÇÃO DO TAMANDUATEÍ, TIETÊ E PINHEIROS}

Com a intenção de melhorar as condições de saneamento das várzeas do Tamanduateí, conhecidas como várzea do Carmo, a primeira intervenção nesse rio aconteceu em 1841 a partir da construção de um canal que modificava parte do seu curso ${ }^{5}$ - ver mapa das páginas 142-143. Com a mesma intenção, em 1848, o trecho do rio conhecido como sete voltas foi retificado a partir de uma encomenda do Governo Provincial. Essas obras, além de não surtirem o efeito desejado, inviabilizaram a prática secular da navegação nesse rio. Em 1872 e anos posteriores, foi canalizado o trecho do rio entre o Ipiranga e a Ponte Pequena - ver mapa das páginas 34 e 35. Nessa mesma intervenção foi realizado o aterramento de parte da várzea do Carmo onde foi instalado um jardim conhecido como "ilha dos amores". Entretanto, as inundações e transbordamentos do Tamanduateí continuaram. (MATTES, 2001)

A partir do final do século XIX e começo do século XX, o interesse das elites e do poder público era equipar a cidade, transformando-a em um centro moderno e civilizado, em oposição ao rural como imagem do atraso e do arcaico. Utilizando a legislação como instrumento, foram expulsas do centro populações indesejadas como negros, prostitutas, "vagabundos" e "desocupados". Isso se aliava aos interesses dos agentes imobiliários interessados nas imensas áreas livres da várzea do Carmo. O crescimento populacional agravava a condição do rio e epidemias se tornaram frequentes. Nesse momento, o conhecimento científico se esta-

\footnotetext{
4. OSEKI, Jorge H. e MAUTNER, Yvonne M. M., "O espaço das redes de serviços em São Paulo" p.13-20, in Sinopses 20, FAUUSP, São Paulo 1993.

5. Essa obra foi coordenada pelo engenheiro alemão Karl Abrahan Bresser, sendo que não há registros da mão de obra utilizada nessa construção.
} 
belecia como o responsável pela solução dos problemas de saúde pública. Apesar do avanço nas descobertas da microbiologia, a utilização da ideia de salubridade teve grande utilidade nas intervenções realizadas nas várzeas dos rios paulistanos. Esse discurso, tornado uma ideologia, foi muito bem explorado ${ }^{6}$ pelo mercado imobiliário.?

Diante da continuidade dos problemas de salubridade nas margens do Tamanduateí, foi criada a Companhia Parque da Várzea do Carmo, financiada pelo Banco Português do Brasil, com o objetivo de sanear as várzeas. $O$ contrato de concessão determinava que a Companhia receberia como pagamento pelas obras uma parcela dos terrenos localizados em sua redondeza, já devidamente saneados.(SANTOS, 2011) A obra foi inaugurada em 1922 dando origem ao parque D. Pedro II e, mesmo sem atingir os objetivos do projeto, as propriedades da região passaram por intensa valorização. Mesmo antes da conclusão das obras, a Companhia tratou de parcelar a região, colocando-a à disposição do mercado. No fim do empreendimento, a Companhia havia obtido enorme capitalização de mais $300 \%{ }^{8}$.

O rio Tamanduateí já não comportava mais a navegação e a pesca encontrava-se prejudicada nesse rio desde meados do século XIX devido à poluição de suas águas. Da mesma forma, atividades como de lavadeiras, extração de areias, pedregulhos e argilas para a construção,

6. "Varíola, cólera, febre amarela e tifoide e tuberculose eram moléstias comumente encontradas nos bairros próximos às ferrovias, nos centrais de Santa Ifigênia e Bela Vista, e nos médios como Santa Cecília, Vila Buarque e Consolação. Os relatórios do Serviço Sanitário deixam claro que o Estado e o Município procuravam redistribuir o espaço da cidade mediante sua divisão em zonas funcionais, valendo-se da topografia acidentada e do grau de salubridade que os terrenos proporcionavam. Médicos e engenheiros forneceram o diagnóstico." (SANTOS, 2011, p.132)

7. SANTOS, Fábio Alexandre dos. Domando Águas, Salubridade e ocupação do espaço na cidade de São Paulo, 1875 - 1930. São Paulo: Alameda, 2011 e ROLNIK, Raquel. A Cidade e a Lei: legislação, política urbana e territórios na cidade de São Paulo, São Paulo: Studio Nobel: Fapesp, 2003.

8. Segundo Fábio Alexandre dos Santos, "os lotes eram vendidos com prazo de 10 anos para o pagamento, sendo essencialmente direcionado ao comércio. Até 19 de janeiro de 1928, quando a Companhia publicou os valores alcançados com a comercialização dos imóveis, a empresa havia totalizado 7.536:329\$000 em vendas. Vale atentar para este resultado, mesmo que parcial e bruto, em contraposição ao orçamento inicial da obra do parque do Carmo, de 2.276:70 $\$ 386$, a partir do qual é permissível supor que o empreendimento resultou num lucro bruto Cia. Parque da Várzea do Carmo na ordem de 5.259:623\$614 (5 mil duzentos e cinquenta e nove contos de réis)". (SANTOS, 2011, p.166) 
praticadas desde séculos anteriores, sofreram grande diminuição com a contaminação, proibição e controle do usos das águas e com a posterior privatização da várzea do Carmo.

A urbanização de São Paulo passava a se relacionar mais com o processo de produção e circulação de mercadorias e com a industrialização. A retificação dos rios passou a ser uma necessidade histórica relacionada ao processo de desenvolvimento econômico e social de caráter modernizador e progressista. ${ }^{9}$ A atuação do poder público buscou prover a cidade com as condições necessárias ao desenvolvimento industrial.

O projeto de retificação dos rios Tietê e Pinheiros foi empreendido pela Prefeitura Municipal e pela companhia canadense Light $\mathcal{E}$ Power, respectivamente, abrindo uma enorme possibilidade de valorização, não somente das áreas diretamente envolvidas e das áreas adjacentes, mas também da valorização da cidade como um todo.

O debate que aconteceu no âmbito público e privado, no momento da implantação dessas obras, envolveu, basicamente, questões relacionadas à apropriação privada de investimentos públicos, ou seja, como e de que forma acontece a incorporação da valorização imobiliária gerada pela provisão pública de infraestruturas. (SEABRA, 1994)

No Tietê, os planos de intervenção no rio aconteceram no âmbito da Comissão de Saneamento do Estado de São Paulo, ao estudar o regime dos rios da bacia do Tietê. A partir da extinção dessa comissão em 1898 e diante da ameaça de crises epidêmicas, diversas obras pontuais foram realizadas no rio visando a resolução de problemas de insalubridade e obstrução do curso do rio, como a supressão de ilhas fluviais e alguns meandros a partir da construção de canais fragmentados no Anastácio e em $\mathrm{Osasco}^{10}$ - ver mapa das páginas 34-35 $5^{11}$.

Durante a vigência da Comissão de Saneamento da Capital, já havia a preocupação de como a municipalidade seria ressarcida pelos investi-

9. SEABRA, Odette C. De L., Os Meandros dos Rios nos Meandros do Poder: Tietê e Pinheiros - valorização das várzeas de São Paulo. Tese de doutoramento, FFLCH-DG/USP, São Paulo, 1994.

10. Nessa intervenção a ilha de Inhaumas foi removida a partir da abertura de um canal de 1.220 metros. O canal do Anastácio tinha 1.260 metros e o de Osasco, 620. Também foi realizada a desobstrução de uma curva do rio próxima a Estrada de Ferro Sorocabana. (MATTES, 2001)

11. Esse mapa de 1926, realizado pelo Serviço Geográfico Militar, não mostra o projeto de retificação que foi executado no rio Tietê. Entretanto, o projeto que foi executado é muito similar ao que esse mapa apresenta. 
mentos públicos realizados em melhorias e produção de infraestruturas, propondo para isso a cobrança de taxas dos proprietários de terrenos beneficiados. Na vigência da Comissão de Melhoramentos do rio Tietêt ${ }^{12}$, sob a coordenação do engenheiro Francisco Saturnino de Brito, foi proposta uma tributação específica chamada Contribuição de Melhoria, como forma de se cobrar proporcionalmente pela valorização fundiária criada pelo investimento público. Saturnino de Brito propôs um projeto para o Tietê que, em tese, resolvia a questão das cheias e drenagem nesse rio, além do tratamento de água para fornecimento ${ }^{13}$. No entanto essas discussões não evoluíram e os projetos das comissões foram engavetados. (SEABRA, 1994)

O projeto que foi colocado em prática no Tietê não resolvia por completo os problemas de vazão do rio e drenagem das várzeas, ainda que as propostas de Saturnino de Brito indicassem que havia conhecimento técnico para isso. A prefeitura realizou a maior parte dos trabalhos, desapropriando apenas as terras necessárias para o reposicionamento do canal e, seguindo o Código de Águas de 1934, tornou-se proprietária somente das terras referentes ao antigo leito do Tietê, ou seja, terras fragmentadas de meandros abandonados. Esse processo resultou na não aplicação de cobranças referentes à valorização de terras pelas obras, ficando a municipalidade sem qualquer ressarcimento pelos investimentos realizados. (SEABRA, 1994)

As várzeas drenadas do Tietê implicaram novas formas de uso da terra e limitaram os usos da água. Esse espaço foi incorporado ao tecido da cidade a partir da sua apropriação por proprietários de terras das várzeas, gerando ganhos derivados de investimentos públicos (SEABRA, 1994).

Conclui-se que, no fenômeno urbano, a forma com que as condições gerais de produção são implementadas inclui a socialização dos custos para sua construção, ainda que as valorizações provenientes desse investimento sejam apropriadas privadamente. ${ }^{14}$

12. A Comissão de Melhoramentos do Rio Tietê foi criada em 1924.

13. Os trabalhos da Comissão de Melhoramentos, coordenada pelo engenheiro Francisco Saturnino de Brito, reconhecidamente, representou uma substancial avanço no conhecimento científico dos rios (especialmente o Tietê) e das várzeas, realizando diversas medições e prospecções, calculando inclusive a quantidade de metros quadrados beneficiados pelas obras de retificação para a cobrança da contribuição. (SEABRA, 1994)

14. "Na cidade capitalista moderna criam-se condições gerais sociais de produção, 
O caso mais emblemático de intervenção em rios de São Paulo talvez seja o do rio Pinheiros. Contando cada vez mais com a presença do capital estrangeiro, através de empresas de serviços públicos, a cidade foi equipada com infraestruturas como as redes de distribuição de energia elétrica, água, esgoto, gás e transporte por bonde entre outras.

A The São Paulo Tramway Light and Power Co Ltd, companhia de serviços urbanos de capital inglês com sede no Canadá, começou a operar no Brasil no momento em que a energia elétrica e o transporte de mercadorias e trabalhadores se tornavam essenciais para a produção industrial. A necessidade de fornecimento de eletricidade no processo de industrialização fazia com que fosse necessário produzir água ${ }^{15}$, ampliando a necessidade de apropriação e controle sobre os rios. Além da crescente demanda da cidade por esses serviços, essas atividades representavam uma excelente oportunidade para a Companhia aumentar a capacidade de produção e venda de energia elétrica e transporte. Dessa forma, o sistema da Companhia contava, já no início do século XX, com algumas usinas $^{16}$. (SEABRA, 1994)

Em 1907, o rio Guarapiranga, formador do rio Pinheiros, foi represado, formando a represa do Guarapiranga. $O$ intuito era regularizar o fornecimento de água para garantir o volume necessário ao funcionamento das usinas do sistema nos meses de estiagem. A partir daí, a Light começa os estudos para viabilizar a produção de energia utilizando as águas do rio Tietê para acionar uma usina em Cubatão, futura usina de

o que equivale dizer que a cidade tem que ser funcional à reprodução capitalista da riqueza. Nela, nenhum capitalista individual construirá a sua própria estrada. A administração pública assumiu historicamente esses encargos de produção e de gestão da cidade, os quais aparecem ao nível do fluxo total da riqueza como uma racionalidade necessária do processo de reprodução social. Subtrair dos habitantes da cidade o rio e as várzeas, pela canalização e drenagem, para usá-los como capital social, com as obras de infraestrutura viária que se sucederam, era o caminho da socialização. Uma socialização que se dá pelo lado da produção material da riqueza que integra o rio e as várzeas aos circuitos produtivos do capital geral, essencialmente, capital privado. $O$ rio vai ser apropriado com vistas à produção de energia e as várzeas como espaço de circulação de mercadorias." (SEABRA, 1994, p.150)

15. VICTORINO, Valério Igor. Luz e poder na dramática conquista do meio natural: A privatização dos rios paulistanos e a reflexividade sócio-ambiental. São Paulo: Tese de Doutoramento, FFLCH USP, 2002-a.

16. O sistema de produção de energia da Light contava com a usina de Parnaíba, que já funcionava desde 1901, além das usinas de Porto Góis, Rasgão e Itupararanga. (SEABRA, 1994) 
Henri Borden, aproveitando-se do desnível da Serra do Mar. Para isso, o rio Grande, atual Jurubatuba, outro formador do rio Pinheiros, foi represado, formando a represa Billings. Seu curso foi desviado até o rio das Pedras para que daí suas águas fossem lançadas na Serra do Mar até Cubatão. As águas do rio Tietê, maior rio em volume da região, deveriam ser conduzidas pelo canal do rio Pinheiros, agora com seu sentido invertido, garantindo assim o volume de água na usina de Cubatão. (SEABRA, 1994)

A ENCHENTE DE 1929

A formalização da concessão para a exploração desse sistema pela Companhia Light aconteceu em um momento em que as leis que regulavam a utilização dos recursos hídricos na cidade ainda eram muito imprecisos. Aproveitando uma brecha no contrato de concessão e exercendo forte influência no poder público, a Companhia obteve o direito de promover as obras necessárias para colocar em prática o seu projeto. Essas obras contavam com a canalização, alargamento, retificação e aprofundamento dos leitos dos rios Pinheiros, Grande e Guarapiranga, além da drenagem, saneamento e beneficiamento dos terrenos sujeitos a inundações. Em contrapartida, a empresa, além de contar com o monopólio da produção, distribuição e venda de energia elétrica e transporte por bonde, obteve o direito de desapropriar todos os terrenos que gozassem das melhorias empreendidas por ela, ou seja, os terrenos sujeitos a inundações, as várzeas. Assim, a empresa podia cobrar o custo do benefício e participar da valorização dos terrenos promovida pelas obras que empreenderia, feito que o Governo Municipal não conseguiu implementar no momento da retificação do Tietê. A questão é que essa valorização era muito maior que o custo integral do investimento que a Companhia realizaria. (SEABRA, 1994)

A brecha na lei de concessão estava justamente no fato de não haver qualquer menção sobre quais seriam as zonas inundáveis, ficando indefinidas até que esse perímetro fosse, posteriormente, identificado como sendo a linha da máxima enchente. (SEABRA, 1994)

Segundo a geógrafa Odette Seabra (1994), a enchente de 1929 foi uma ação estratégica de valorização realizada pela Light. A partir de dados pluviométricos e de depoimentos e matérias de jornais da época, 
Seabra provou que a enchente de 1929 foi produzida pela Light a partir da abertura das comportas de suas represas com a intenção de aumentar o perímetro das terras a que teria o direito de desapropriação, causando incalculáveis danos à população ribeirinha ${ }^{17}$. Dessa forma, percebese que esse evento não foi precisamente uma enchente, mas sim, uma inundação. (SEABRA, 1994)

Os mapas das páginas 40-41 e 42-43 foram produzidos através da sobreposição do arruamento, do curso original dos principais rios de São Paulo e da cota $724^{18}$, cota da máxima enchente registrada em fevereiro de 1929. Essa imagem nos mostra como os rios realmente "desapareceram" após sua canalização, sendo suas várzeas incorporadas ao tecido da cidade. Apesar de a representação da cota 724 não necessariamente corresponder com precisão ao perímetro da enchente de $1929^{19}$, essa imagem revela a brutalidade do processo de apropriação da terra e da água em São Paulo.

É possível notar nesses mapas que a urbanização das cotas inferiores e superiores à cota de inundação apresentam algumas diferenças, principalmente quanto ao arruamento, loteamento e tamanho dos lotes. Ainda que isso seja perceptível, praticamente não há vestígios do espaço antes dominado pelos rios e meandros em suas cheias periódicas, espaços que, no início da ocupação de São Paulo, eram considerados espaços de apropriação comum, de uso comum, e onde atualmente não se percebe qualquer permanência desse sentido nos espaços resultantes dessa urbanização - ver folha do Sara Brasil, páginas 38 e 39.

17. No dia 19 de fevereiro de 1929, dia em que o rio Pinheiros atingiu seu maior nível registrado, cota 724, representantes da Companhia Light, da Prefeitura e engenheiros da Escola Politécnica, trataram de medir e registrar oficialmente essa cota, determinando assim, o perímetro da enchente. (SEABRA, 1994)

18. Para a confecção desse mapa, o arruamento da cidade foi obtido no GEOLOG, disponível no CESAD da FAUUSP, e o curso "original"dos rios, no Mapa das Chácaras de São Paulo, parte do acervo do Museu Paulista da USP. Somente os rios Pinheiros e Tietê aparecem em seu estado original e o Tamanduateí já apresenta algumas retificações. A cota 724 não aparece no GEOLOG e assim foi obtida no Mapa Digital da Cidade - MDC, disponível no site da Prefeitura Municipal de São Paulo.

19. Isso acontece devido a modificações e obras de aterramento que transformam o perímetro da cota, como por exemplo o aterro do Parque Villa Lobos, na zona oeste, que não existia na ocasião da enchente. A cota da enchente foi obtida com referência no nível do mar sendo que nessa época os equipamentos de medição já eram bastante precisos, o que garante que a cota 724 aferida em 1929 é praticamente a mesma do MDC. 
A partir da enchente, iniciou-se uma batalha pelo direito de propriedade das várzeas do Pinheiros, com disputas judiciais que durariam décadas e terminariam com a totalidade dos terrenos sob a propriedade da Light. Nem mesmo outras grandes empresas de serviços urbanos, que operavam em São Paulo no mesmo período, foram capazes de parar a Companhia. Mesmo a municipalidade que, em diversas ocasiões, questionou a validade da concessão, não obteve sucesso, sendo, inclusive, processada pela Companhia pelo custo do benefício que as obras no Pinheiros ocasionaram em terras de propriedade municipal.

Já na metade do século, a cidade sofria com o abastecimento de energia deficitário, sendo necessária a adoção de medidas de racionamento na rede da Light. Após a entrega do canal para a administração pública na década de 1960, terrenos da Light no vale do Pinheiros começaram a ser desapropriados ${ }^{20}$ para a instalação do sistema viário de avenidas, alças e pontes hoje existente. Esses projetos começaram a ser executados com recursos do Banco Mundial.

Após a conclusão dos trabalhos de retificação dos rios Tietê e Pinheiros e o aumento da área urbanizada nas suas bacias, a cidade passou a enfrentar frequentes inundações, passando a ser esse o foco das atenções nas atuações do poder público. Diversas obras e projetos foram postos em prática nas décadas seguintes, muitas delas financiados por bancos internacionais com a presença de técnicos estrangeiros, revelando que a cidade e a produção da cidade já integravam uma esfera internacional de investimento, produção e reprodução do capital financeiro, já totalmente descoladas da realidade dos rios. (SEABRA, 1994)

As obras realizadas nos rios Tamanduaté, Tietê e Pinheiros foram responsáveis por suprimir esses rios da cidade, estruturando seus es$\operatorname{paços}^{21}$ e transformando a relação da população da cidade com esses recursos.

O processo de canalização dos rios de São Paulo mostra a impo-

20. Para Seabra, "a investida do poder público sobre as propriedades da Light, e as sua resposta quase que automática de se desfazer das propriedades, ocorreu com uma rapidez assustadora e isso se explicaria, ao que parece, porque nesse período foi notória a ascensão econômica e política de empresas construtoras as quais impuseram sua lógica ao processo." (SEABRA, 1994, p.254)

21. FRANCO, Fernando de Mello. A Construção do Caminho: A estruturação da metrópole pela conformação técnica das várzeas e planícies da Bacia de São Paulo. São Paulo: Tese de Doutoramento, FAUUSP, 2005. 
sição de uma lógica que não só buscava a reprodução das empresas capitalistas, mas também buscava capitalização através de expropriação. "A formação de capital só se realiza pela expropriação de condições de produção, pela extorsão de trabalho social "à margem" das leis de reprodução."(SEABRA, 1994, p.259)

"Não tem volta. Assim como o trabalho foi socializado, produziu-se uma dimensão social do espaço que lhe é consentânea. O espaço da sociedade moderna do capitalismo sintetiza um tempo histórico no qual há absoluto domínio do geral sobre o particular do abstrato sobre o corpóreo". (SEABRA, 1994, p.268)

Conclui-se que as obras nos rios de São Paulo somente puderam ser realizadas no momento em que a propriedade da terra e da água adquiriram uma forma econômica definida sem a qual não poderiam ser inseridos no processo de valorização do espaço através da obtenção de renda.

Entretanto, a história da canalização dos rios Tamanduaté, Tietê e Pinheiros e a supressão das suas várzeas não explicita o processo que transformou os rios de São Paulo de recursos naturais em recursos econômicos. Essas obras aconteceram em um momento em que os rios, suas terras e suas águas já estavam dominados privadamente. O uso dos rios estavam comprometidos e praticamente não existiam mais formas de subsistência pelos rios ${ }^{22}$. A água para ingestão era vendida através do serviço de distribuição encanado, pago em mensalidades, e já não era mais possível encontrar água gratuita em chafarizes nem ingerir as águas poluídas dos rios e córregos da cidade. Ainda que as várzeas não estivessem ocupadas, esses espaços já possuíam proprietários legalmente estabelecidos. Dessa forma, na ocasião da realização das obras de retificação e canalização dos rios Tamanduaté, Tietê e Pinheiros, terra e água já estavam incorporadas aos processos produtivos e de urbanização. Já eram, portanto, mercadorias.

22. Ainda que se saiba que durante boa parte do século XX existiram atividades como a pesca, a dragagem de areia e pedregulho para construções e o futebol de várzea, elas tenderam a acabar com a urbanização dessas áreas. SEABRA, Odette C. De L., Os Meandros dos Rios nos Meandros do Poder: Tietê e Pinheiros valorização das várzeas de São Paulo. Tese de doutoramento, FFLCH-DG/USP, São Paulo, 1994. SEABRA, Odette C. de L.. Urbanização: bairro e vida de bairro, in Travessia São Paulo n. 38 p. 11-17, 2000. 
Para explicitar o processo de incorporação dos rios de São Paulo ao processo de reprodução capitalista, esta pesquisa se estrutura nas seguintes partes e capítulos:

A primeira parte, que contém os três primeiros capítulos, caracteriza a condição dos rios de São Paulo desde a sua fundação no século XVI até o início do século XIX, enfatizando a transformação das atividades relativas aos rios, às águas e às várzeas e a sua relação com o estado da economia de São Paulo e as condições impostas pelo processo de colonização.

O primeiro capítulo apresenta a origem do que se caracterizou como bem comum e sua relação com o desenvolvimento social e econômico de São Paulo, envolvendo a apropriação privada dos então espaços de uso comum. Os rios e a água, contidos nas datas de terra, se caracterizavam como parte desse patrimônio comum, sendo, num primeiro momento, usufruídos como riqueza e que depois passaram a ser incorporados aos processos produtivos. A principal característica dos rios e da água nesse momento é o uso, que passa a ser intermediado por trabalho cativo e submetido à terra pela ausência de qualquer regra para sua utilização. No momento em que a economia paulista era pouco desenvolvida, os rios e córregos de São Paulo eram recursos relevantes para a subsistência da povoação, sendo apropriados e transformados.

O segundo capítulo caracteriza a sobrevivência do trabalho livre de artesãos na sociedade escravocrata paulista, com a baixa especialização de atividades urbanas. A transformação desse cenário acontece a partir da descoberta de ouro em Minas Gerais, Goiás e Mato Grosso, quando São Paulo apresenta algum incremento populacional e comercial, favorecendo a permanência de construtores na vila e um leve incremento na atividade da construção. Nesse contexto foi instalada a primeira rede de condutos de água de São Paulo, um sistema extremamente precário e insuficiente, baseado na instalação de chafarizes e bicas. O texto busca caracterizar os materiais e a mão de obra utilizada nesse primeiro sistema e compreender o seu significado dentro da economia e do contexto onde as formas de apropriação do trabalho se transformavam a partir do avanço na divisão do trabalho. Os despejos de dejetos no rio Tamanduateí proporcionavam os primeiros sinais de poluição desse rio, e a precariedade e insuficiência do sistema de distribuição fazia com que a água não chegasse nos seus destinos, gerando uma infinidade de conflitos entre moradores e as instituições municipais e eclesiásticas. A 
inexistência de regras claras sobre o uso dos rios e da água possibilitava a livre interpretação das formas de sua apropriação, como um reflexo das regras para a apropriação da terra. Essas lutas pelo controle e posse individual da água marcaram o final do século XVIII e o começo do XIX em um momento em que a municipalidade se organizava. A posição da Câmara diante desses conflitos oscilou diante da defesa do bem comum e a sujeição a interesses particulares. A presença de engenheiros envolvidos em obras de infraestrutura em meados da primeira metade do século XIX representou o início da hegemonia dessa disciplina em obras públicas ainda que, nesse momento, a produção de condições gerais não se viabilizassem.

No terceiro capítulo são caracterizadas as atividades relativas aos rios de São Paulo como a pesca, a caça e a lavagem de roupas, e de pequenos comerciantes e a distribuição de água pelos aguadeiros. Aprofundou-se a relação dessas atividades com transformações nas formas de apropriação dos rios e das águas através do trabalho. As atividades que envolviam os rios e que se caracterizavam pela extração direta e utilização sem mediações da água e dos frutos do rio determinavam o uso como a principal característica dos rios. Essas atividades passaram a comportar a troca, possibilitando a obtenção de renda para subsistência. Em algumas dessas atividades, a simples troca de víveres por víveres passou a ser intermediada por dinheiro, ainda que a finalidade última dessa troca seja a subsistência e não a geração de mais dinheiro. Nesses casos, os meios de produção, isto é, terra e água, ainda pertenciam ao produtor direto, diferente do trabalho cativo onde o produtor direto era alienado dos meios de produção. Ainda que essas transformações não implicassem grandes transformações sociais e econômicas, elas conferiram à água a condição de produto do trabalho, ou seja, mercadoria. Isso acontece no momento em que a cidade passava por problemas de abastecimento de água e despejos nos rios, comprometendo diversas dessas atividades.

A segunda parte, apresentada em dois capítulos, caracteriza a relação entre as transformações sociais e econômicas ocorridas durante o século XIX com o processo de urbanização e a sua relação com a produção do espaço a partir da valorização fundiária obtida através da provisão de infraestruturas urbanas, modificando profundamente a relação da cidade e de seus habitantes com os rios e as águas de São Paulo.

O quarto capítulo é dedicado ao aprofundamento das transfor- 
mações sociais e econômicas decorrentes da cultura do café, a partir da proibição do tráfico de escravos, início da imigração e da Lei de Terras. Essas transformações mudaram o significado da aplicação de capital no escravo, implicando a capitalização da propriedade territorial. A maciça importação de mão de obra europeia para trabalhar nas lavouras de café foi precedida da formalização da propriedade fundiária que, a partir disso, não tinha mais qualquer relação com a efetiva posse e ocupação da terra. Isso fez com que o produtor direto, previamente expropriado na Europa, continuasse expropriado dos meios de produção, mantendo, de outra forma, as relações do período escravocrata. Na cidade de São Paulo essas mudanças implicaram a alienação das terras de uso comum, privatizadas a partir de interesses e favorecimentos políticos pelos poderes municipal e provincial. As terras de uso comum, que continham os rios, foram privatizadas ou transformadas em propriedade municipal, passando, terra e água, a ser consideradas mercadorias. Entretanto, a água dos rios, mesmo que sem terra, continuavam a ser consideradas um bem comum. Da inexistência de qualquer menção à água, as leis passam a controlar os rios e espaços da água limitando, impedindo e inviabilizando o seu uso. A ausência de representações cartográficas que registrassem a alienação do patrimônio comum, reforça essa argumentação a partir do redesenho do Mapa das Chácaras.

O quinto e último capítulo aprofunda as transformações físicas e espaciais da cidade de São Paulo, principalmente os aspectos relacionados à água e aos rios, a partir dos desdobramentos da cultura do café no interior da província. No momento em que a cidade recebia enormes massas de trabalhadores europeus e a área urbanizada aumentava, ensaiavam-se novas formas de apropriação do trabalho, a partir da abolição da escravatura e do estabelecimento do trabalho assalariado. A aplicação na terra, cada vez mais considerada um negócio seguro, passava a propiciar a obtenção de renda em dinheiro, implicando o crescimento do mercado de produção de moradia para aluguel.

A poluição dos rios e a precariedade das redes de água e esgotos culminaram no fim da subsistência pelos rios, fato que, nesse momento, auxiliava o processo sujeição do trabalho livre ao capital. A fixação do capital cafeeiro na cidade fez São Paulo florescer. As chácaras ao redor da cidade eram loteadas e o centro recebeu diversas melhorias e embelezamentos. As deficiências no abastecimento de água e esgoto passavam a ameaçar o trabalhador a partir de epidemias. Se a função da cidade pas- 
sava ser a reprodução de capital, seria necessário resolver o problema da água em São Paulo. A produção de infraestruturas urbanas passava a ser um empreendimento rentável. Nesse contexto surge a Companhia Cantareira de Águas e Esgotos, responsável pelo estabelecimento das redes de água e esgoto de São Paulo a partir da captação das águas da serra da Cantareira. Muito pouco foi registrado sobre a mão de obra utilizada nas obras de captação das águas da Cantareira. Entretanto, esses trabalhos tiveram a participação direta de engenheiros ingleses, bem como a utilização de materiais importados da Inglaterra. Com o fim da Companhia e sua encampação, foi criada a estatal Repartição de Águas e Esgotos. A atuação dessas duas empresas foi responsável pelo fim da oferta de água gratuita na cidade de São Paulo.

As redes de água e esgoto de São Paulo foram concluídas em 1883, simultaneamente a diversas outras cidades do mundo, o que revela que a produção de condições gerais foi um fenômeno que aconteceu ao mesmo tempo em todo o mundo. Isso mostra que a valorização fundiária através da provisão de infraestruturas urbanas se mundializava, já estando, portanto, sua produção, muito distante da realidade dos rios. 



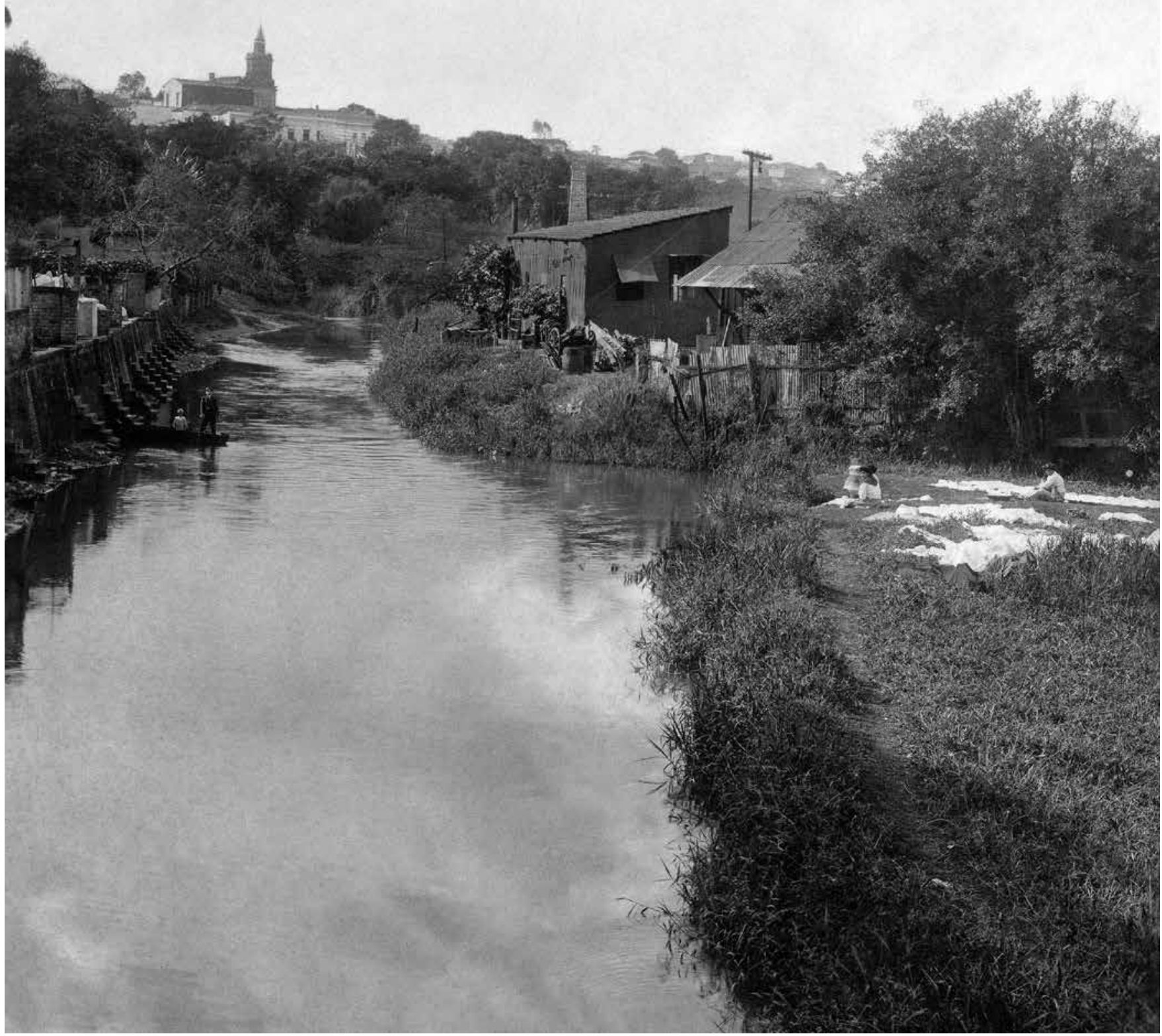




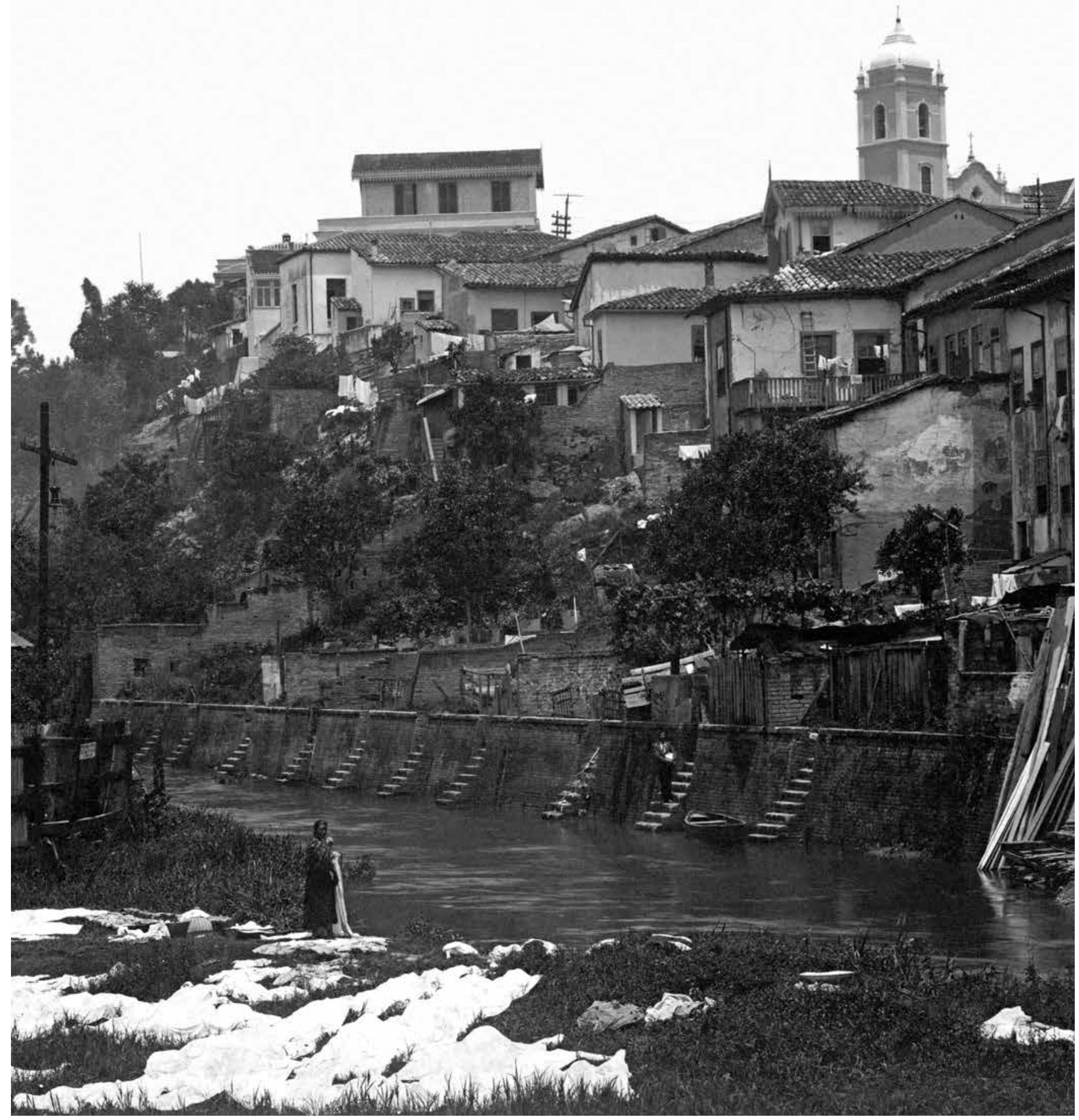


COMMISÃO DE SANEAMENTO DO ESTADO DE SÃO PAULO SECÇÃO DO TAMANDUATEHY PLANTA E PERFIL

DO CANAL DO TAMANDUATEHY

1893

Comissão de Saneamento

Escala Gráfica

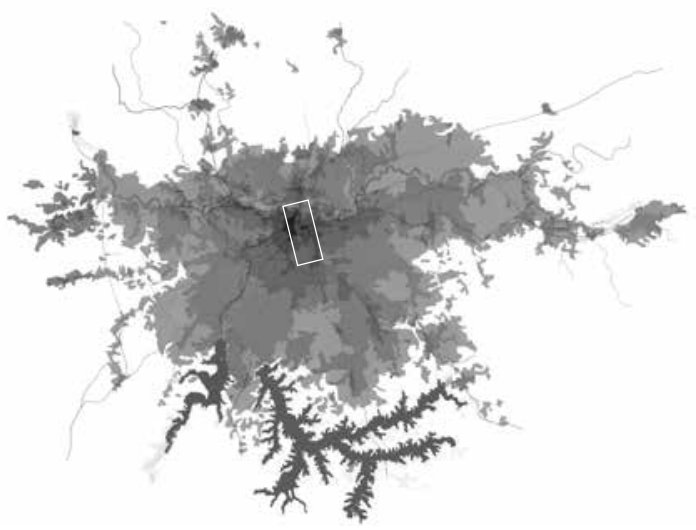

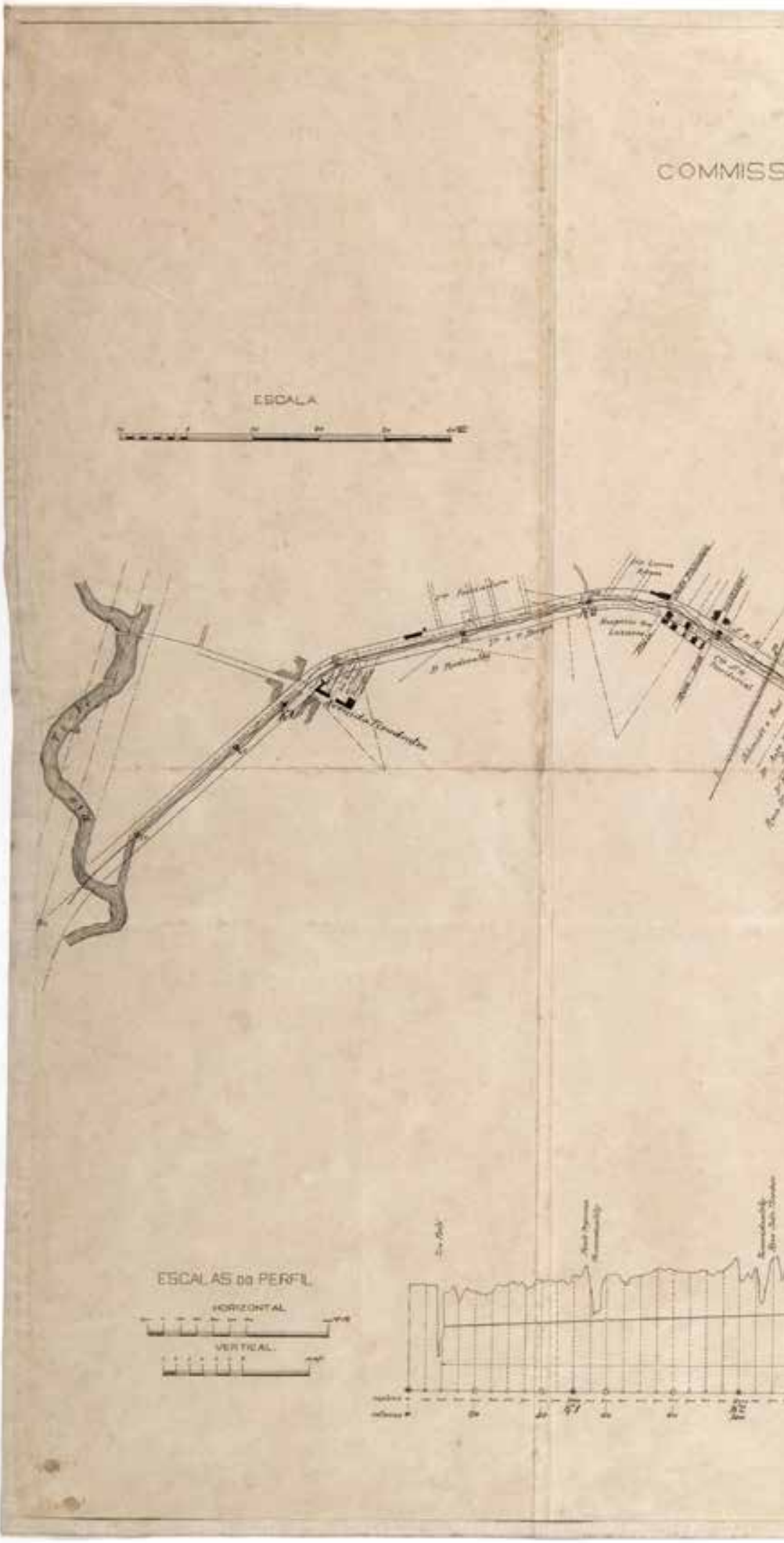


ÄO DE SANEAMENTO DO ESTADO DE SAO PAULO

\section{SECC̣ĀOnT TAMANDUATEHY}

PLANTA E PERFIL

DO CANAL OI TAMANDUATEHY

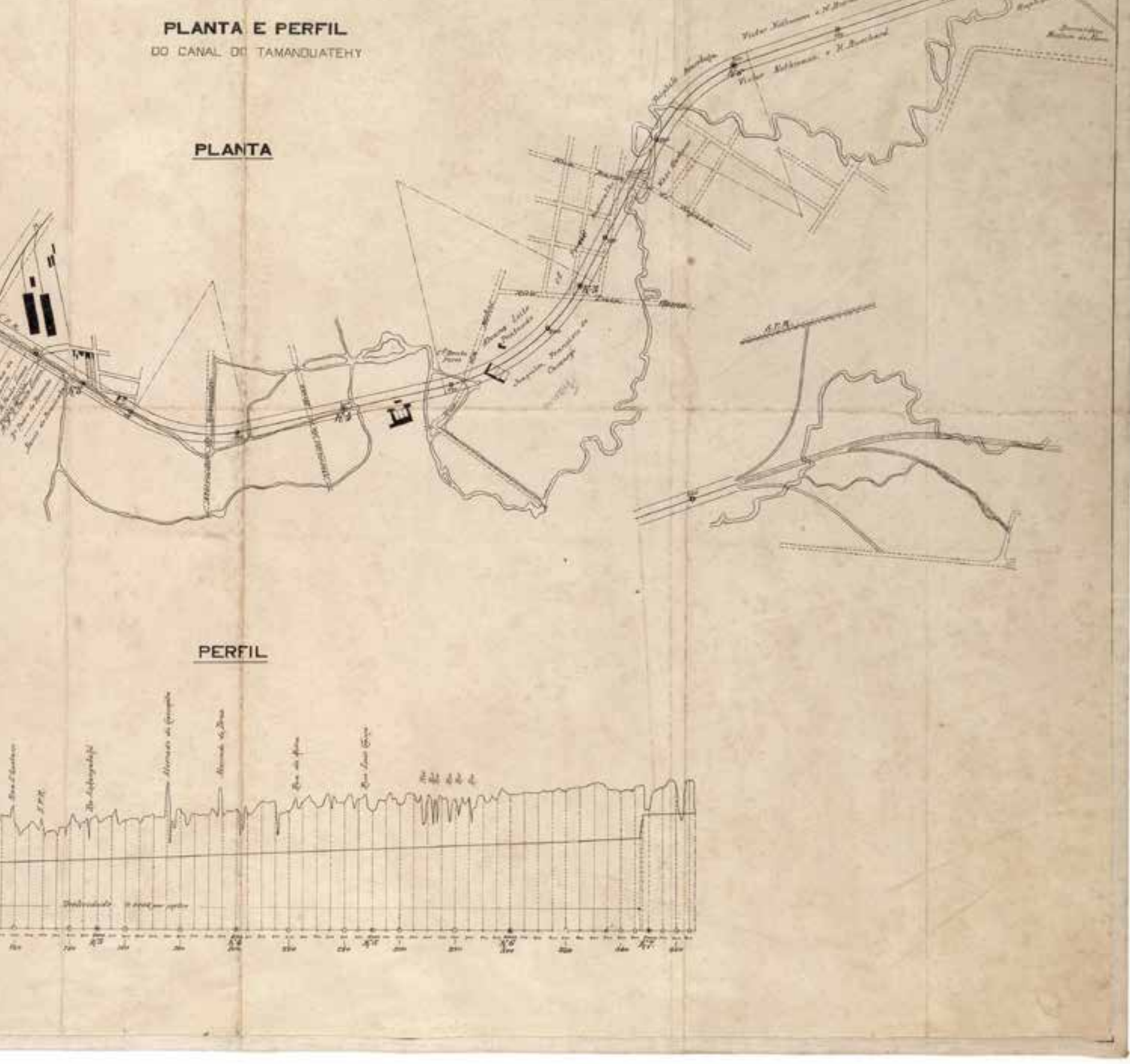




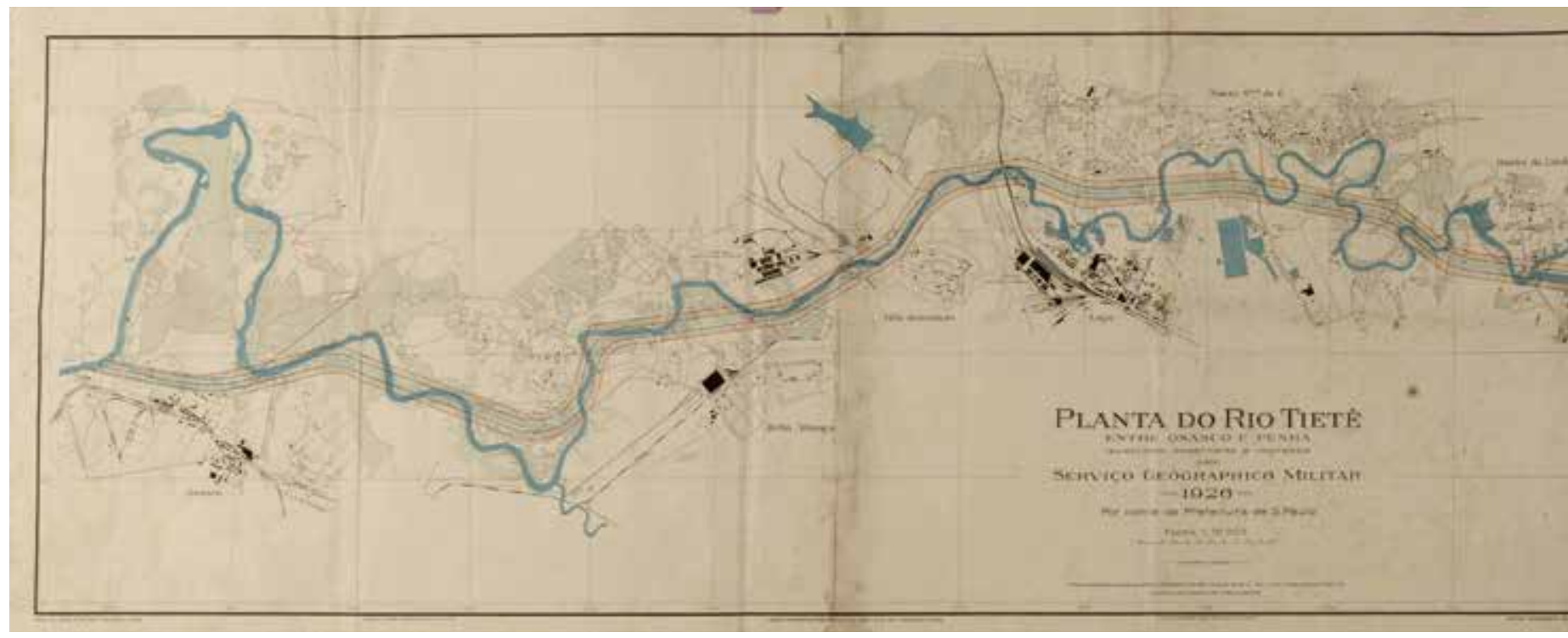

PLANTA DO RIO TIETÉ

ENTRE OSASCO E PENHA

levandada, desenhada e impressa

pelo

SERVIÇO GEOGRAPHICO MILITAR

1926

Por conta da Prefeitura de S. Paulo

ESCALA 1:10.000

1926

Serviço Geográfico Militar

$1: 10.000$

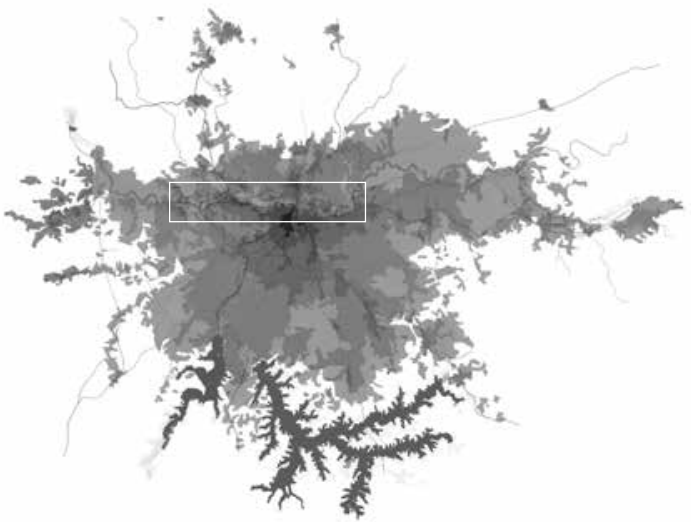



MAPPA TOPOGRAPHICO DO MUNICÍPIO DE SÃO PAULO

Executado pela empreza SARA BRASIL S/A, pelo método Nistri de aerophotogrammetria, de accordo com o contracto lavrado em virtude da Lei No 3208 de 1928, quando Prefeito o

SNR. DR. JOSÉ PIRES DO RIO.

sendo Director de Obras o engenheiro ARTHUR SABOYA.

1930

ESCALA 1:5.000 FOLHA 37

1930

São Paulo - Município - Sara Brasil S/A

1:5.000

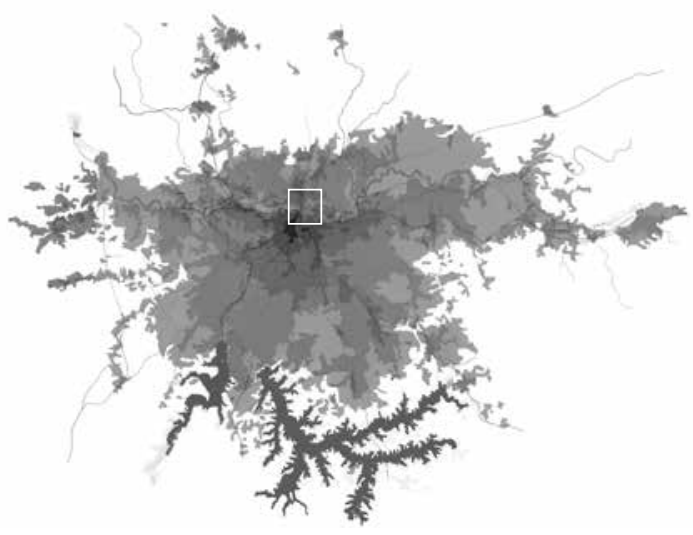




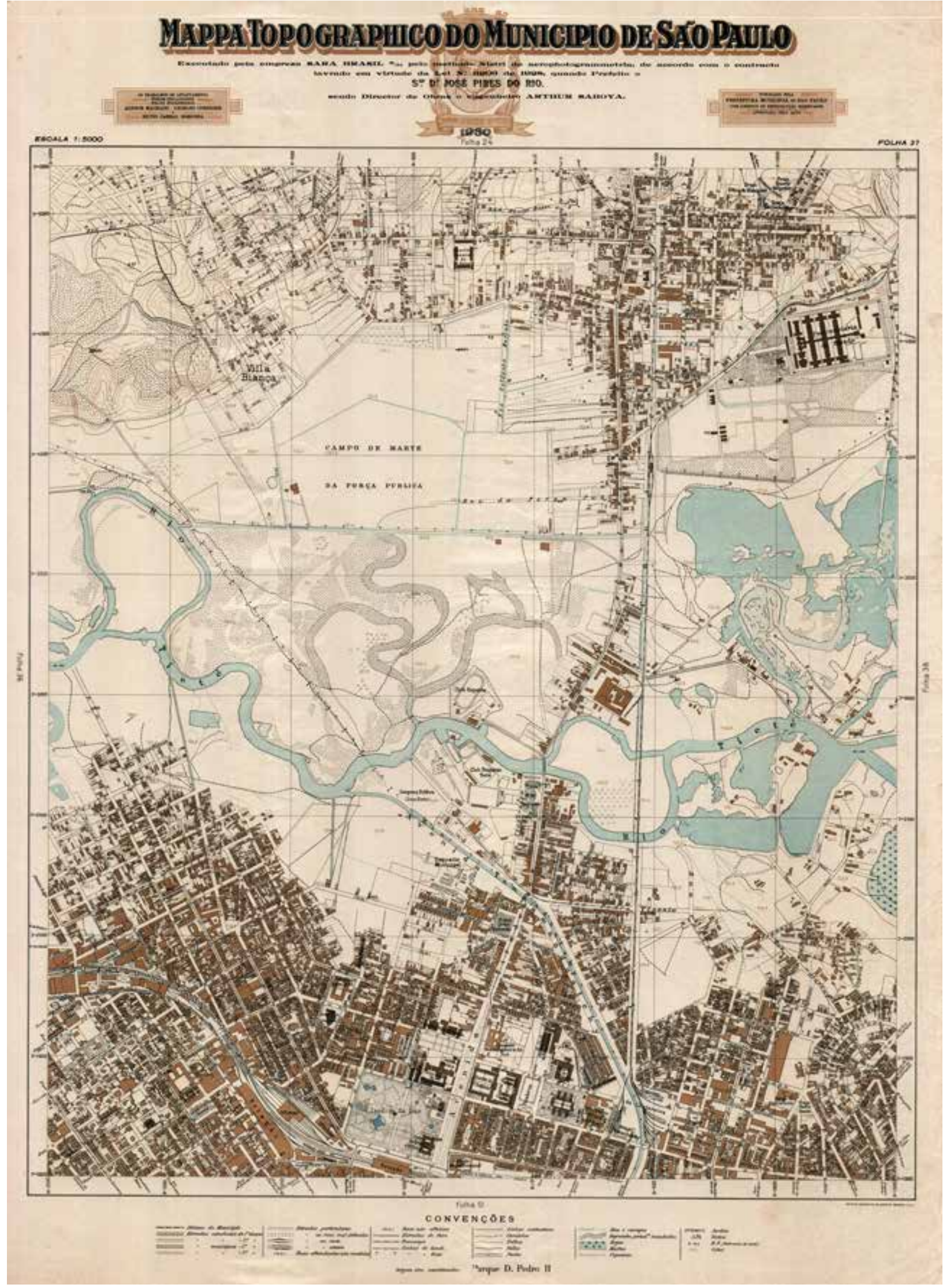


PLANTA DA CIDADE DE SÃO PAULO

representação do nível máximo da enchente de 1929 (cota 724) sobre a estrutura urbana da cidade de 2014

2016

Gouvêa, José Paulo

Escala Gráfica

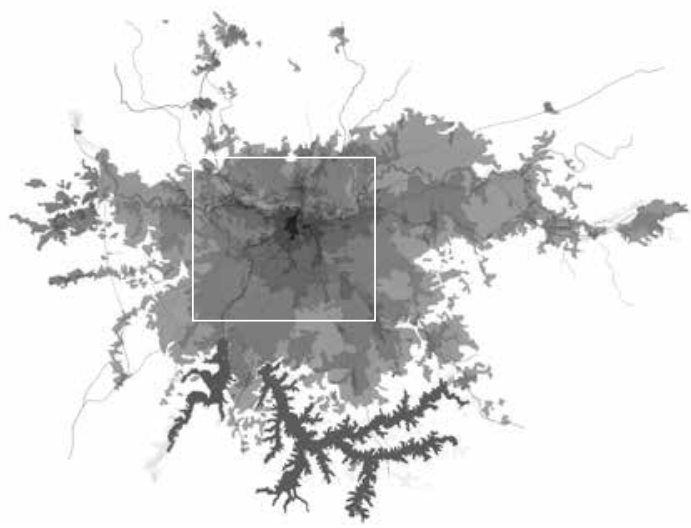




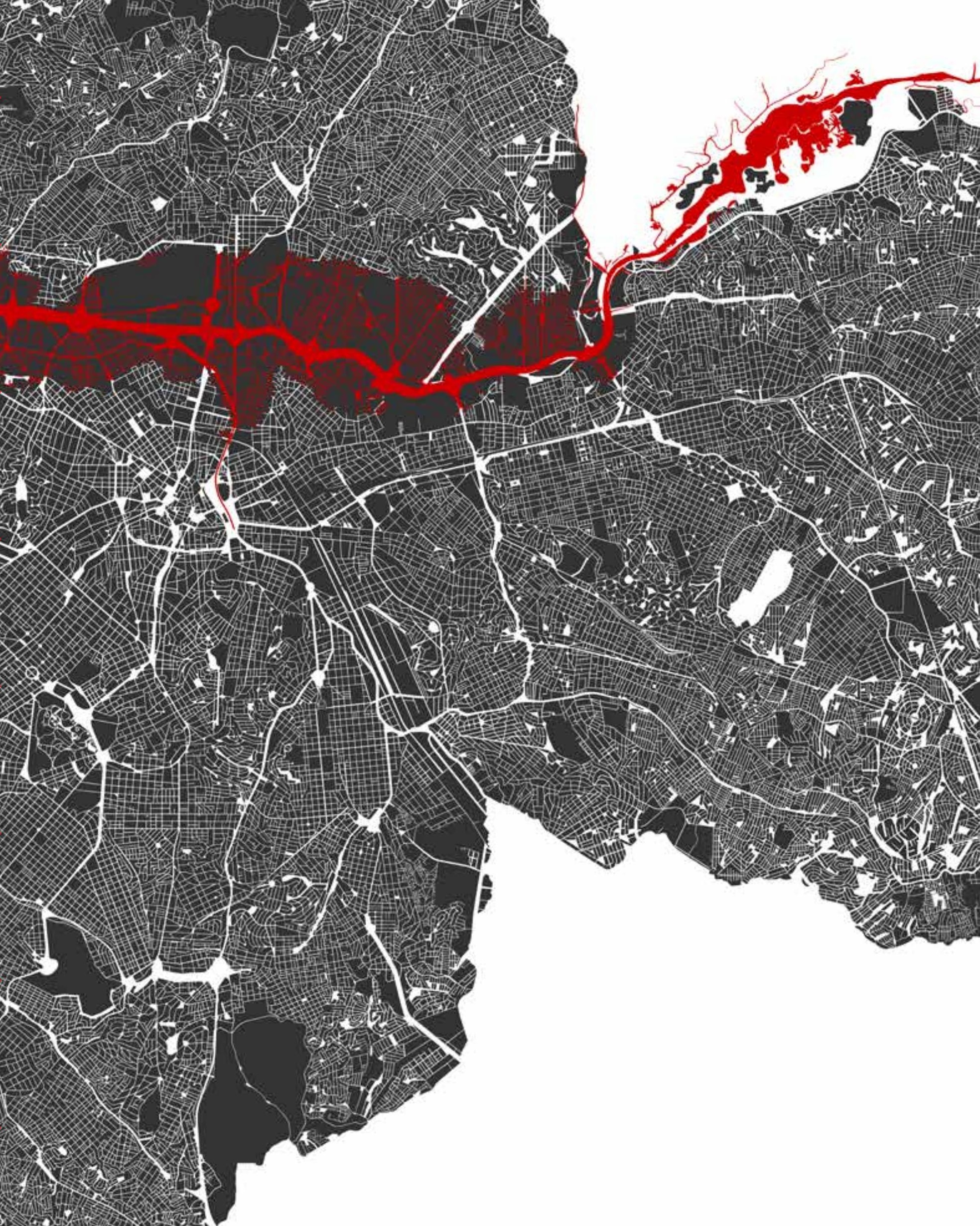


PLANTA DA CIDADE DE SÃO PAULO

representação do nível máximo da enchente de 1929 ( $\operatorname{cota} 724$ ) sobre a topografia e estrutura urbana da cidade de 2014

2016

Gouvêa, José Paulo

Escala Gráfica

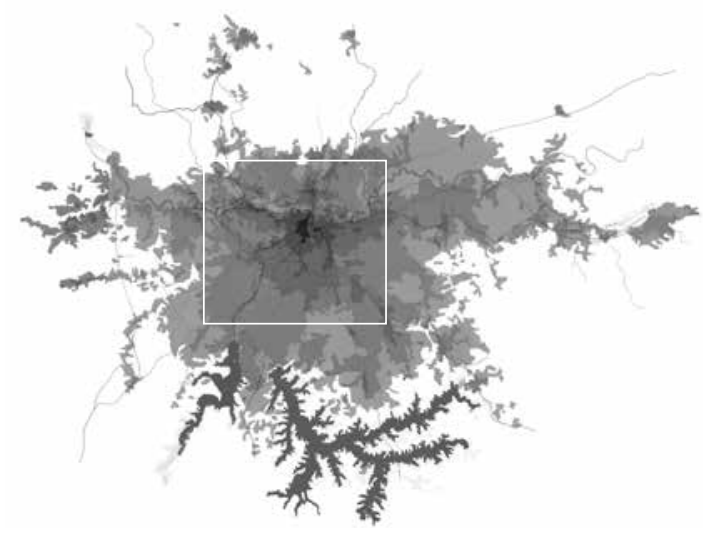




PARTE I - USO DA ÁGUA, SUBSISTÊNCIA E TRABALHO 

O processo em que foi constituído o povoamento que deu origem à cidade de São Paulo, nas descrições e documentos históricos, revela certa despreocupação quanto à definição de espaços que hoje entendemos como públicos. De fato, a designação de espaços como terras realengas, áreas de uso comum, patrimônio do Conselho, termo e rocio, parecem não fazer qualquer sentido atualmente. Essa indefinição parece estar relacionada ao fato de que, quando se trata da apropriação e domínio do espaço, são as terras cuja apropriação é privada que importam, independentemente do caráter jurídico que as legitime. Essa desconsideração quanto à definição de um espaço comum, público e, paralelamente a isso, a clara necessidade de se instituir o domínio privado, acabaram por engendrar um espaço em que se vê claramente o desenvolvimento de um processo de sobreposição do domínio particular sobre o domínio comum.

Ao definir o que são os domínios privados, o que aparece como pretensa necessidade comum é o acesso e a comunicação entre esses domínios, instituindo-se assim, o traçado de caminhos e ruas. Dessa forma, a descrição da propriedade, expressa na definição dos limites do lote, bastava para garantir, de certa forma, a organização do povoamento. ${ }^{23}$

23. ROCHA, Angela Maria. Espaço público e apropriação do espaço: notas sobre a evolução histórica de São Paulo. São Paulo,:Mimeo, 1995. 
Pode-se dizer que esse processo de apropriação se manifesta também no caráter do relacionamento que se estabelece entre os indivíduos, através da mediação de acessos e de caminhos, e não de um espaço em que se possa exercer o sentido público, espaço da manifestação das aspirações comuns, que vai muito além da manifestação das necessidades comuns.

Os debates sobre questões de interesse do conjunto dos moradores aconteciam, geralmente, à saída da missa, em frente à igreja, fundindo o espaço de domínio religioso com o espaço dos assuntos políticos e administrativos. Nos primeiros anos, não se contava com um lugar adequado para que se reunissem os membros do Conselho. A casa onde a Câmara se reunia era precária. Mesmo a forca, considerada um elemento simbólico do domínio da coroa, não era mantida adequadamente. Para a manutenção de caminhos e pontes, solicitava-se o auxílio dos moradores, que cediam escravos para a execução de trabalhos. (ROCHA, 1995)

Mesmo os serviços destinados ao conjunto da população pareciam estar relacionados apenas ao atendimento das necessidades das propriedades individuais, no caso, caminhos, pontes e vias de acesso aos domínios privados.

Nos primeiros cem anos da vila, a própria manutenção e ordenação do conjunto edificado e a edificar aparecem como decorrência da topografia da vila e dos muros que a cercavam, denotando a prevalência do sentido de defesa sobre os de organização social e espacial. Era comum que moradores se aproveitassem dos muros para compor sua própria moradia, não havendo qualquer questionamento sobre sua implantação. (ROCHA, 1995)

É dessa forma que se entendia e era praticado aquilo que, na época, se designava como bem comum, e que se aproxima, mas não se confunde com o que hoje conhecemos como público. Em São Paulo, a ideia da existência de um bem, um patrimônio que é comum, isto é, de todos, é um conceito que existiu mas que parece ter desaparecido junto com esses espaços. Essas áreas "deveriam permanecer livres da apropriação priva$\mathrm{da}$, para serem usadas por qualquer um que delas necessitassem, abertas a todos e a ninguém em especial" 24

Em contraposição a essa forma de tratar os espaços, a colonização

24. BRITO, Mônica Silveira. Modernização e tradição: urbanização, propriedade da terra e crédito hipotecário em São Paulo na segunda metade do século XIX. 2007. Tese de Doutorado apresentada ao Departamento de Geografia da FFLCH-USP, 2007, p.57. 
castelhana, por exemplo, fundada nos preceitos definidos pelas leis das Índias quanto ao traçado urbano, compreendia, por sua própria existência, a consideração de um poder que transcendia o indivíduo na constituição dos espaços, capaz de delimitar os interesses particulares, ainda que em favor de interesses outros, não necessariamente os comuns, ou públicos. (ROCHA, 1995)

Os espaços destinados ao uso comum tinham importância na imediaticidade da vida cotidiana da povoação. Sua denominação variou conforme os períodos históricos: rocio, terras realengas, patrimônio do Conselho, entre outros. Esses espaços de domínio comum incluem terra e água, além de todos os meios de subsistência neles encontrados.

Os apelos do Conselho ${ }^{25}$, futuras Câmaras Municipais, quanto às demandas de interesse pretensamente comum parecem não ter encontrado grande respaldo entre os moradores. Visto que não se percebe, nessas condições, a existência de espaços comunais, sejam eles campos de pastagem, matas, rios ou várzeas, que possam ter evoluído para espaços onde se manifesta essa condição de bem comum, ou seja, de espaços que pertencem, ao mesmo tempo que servem, a todo o conjunto de moradores onde o sentido dominante é o do uso desses espaços e dos recursos neles existentes. O que prevaleceu, aparentemente, é um sentido de individualismo que transformou a natureza e se espacializou no que entendemos como um processo que, de partida, se mostrou extremamente contraditório.

Esse processo, que corresponde à apropriação privada dos espaços de domínio comum, ou seja, sua expropriação, inclui a própria deterioração desses bens.

ORIGENS DO ROCIO E DA ORGANIZAÇÃO MUNICIPAL

A parcela de terras que se submetia à administração da Câmara teve, historicamente, um tratamento diferenciado se comparada ao tratamento

25. Segundo Lúcia Simoni, a designação Conselho, "com o tempo, passou a de Câmara ou Senado da Câmara e, mais tarde, Câmara municipal" (SIMONI, Lúcia Noemia. $\mathrm{O}$ arruamento de terras e o processo de formação do espaço urbano no Município de São Paulo: 1840-1930. São Paulo, Tese de Doutorado FAUUSP, 2002) 
dado às terras rurai ${ }^{26}$. Desde a legislação colonial, essas terras ganharam, no decorrer dos séculos, um caráter difuso, de forma que "expressões como bens do Conselho, rocio, termo e área de uso comum não tiveram seus conteúdos claramente estabelecidos" (GLEZER, 1992). No Brasil, no período colonial, era comum atribuir às vilas e cidades uma porção de terras denominada termo. Sobre essa área a Câmara exercia sua jurisdição, isto é, essa área equivaleria ao que atualmente chamamos de "limite de município". Além do termo, as cidades e vilas contavam com o rocio ${ }^{27}$. A origem da expressão rocio, se refere à

“[...] área destinada ao uso comum, e só podia ser doada para moradia ou aforada, pois era parte integrante dos bens do Concelho. No decorrer dos séculos, de 'terras de uso comum', rossio se transformou na área de controle direto da Câmara, como se fosse o termo, como aparece nos textos dos anos seiscentos [...]" (GLEZER, 1992, p.136)

A forma de obtenção de terras para propriedade rural (as sesmarias) e para a propriedade urbana (as datas de terra) era distinta. As sesmarias poderiam ser obtidas para exploração por um ato do rei, feito diretamente por ele ou por um donatário, mediante alguns requisitos do solicitante, como situação social e financeira. Já as datas de terra eram cedidas pela Câmara, instância de poder local que podia conceder terras para moradia e exploração. Essa concessão poderia acontecer gratuitamente ou através do foro, que significava um pagamento através de parte de seus rendimentos. Os critérios para a concessão de datas de terra era baseada na necessidade e na pobreza do solicitante, no fato deste morar na vila ou na troca de favores com a Câmara, entre outros. Os chãos de terra, como também eram conhecidas as datas, eram cedidas a quem as solicitasse (GLEZER, 1992). Estando submetidas ao poder local, as datas de terra também estiveram sob o domínio dos interesses locais, servindo como

26. GLEZER, Raquel. Chão de terra: um estudo sobre São Paulo colonial. São Paulo: Livre Docência, FFLCH-USP, 1992.

27. Segundo Mônica Silveira Brito "é importante ressaltar que o rocio de uma vila ou cidade não deve ser confundido com o termo, em geral com 6 léguas de raio (cerca de $40 \mathrm{~km}$ ), que era a área de jurisdição do Conselho. O termo incluía, além do rocio, propriedades particulares (terras já doadas em sesmarias) e terras desocupadas ou devolutas, que legalmente se constituíam em propriedade do Governo Central ou Provincial". MARX, Murillo. Cidade no Brasil: Terra de quem? São Paulo, Edusp/Nobel, 1991 apud. BRITO, 2007, p58. 
um eficiente instrumento de negociação política e influenciando diretamente a forma pela qual as áreas de uso comum eram percebidas e utilizadas.

Dessa forma, é possível entender que as datas de terra eram porções de terra urbana que faziam parte do patrimônio do Conselho, ou seja, as terras de uso comum, o rocio. No caso da cidade de São Paulo, as expressões que designavam esses espaços foram se tornando indistintas e quase sinônimas. Não somente as expressões foram se fundindo mas também esses espaços foram se confundindo com o termo.

Com relação a esse patrimônio, no que se refere aos padrões que foram adotados no Brasil, podemos entender suas atribuições através da carta de concessão e demarcação do rocio de São Paulo, de 1598:

“[... para rossio desta ditta vila para cazas e para gado e para tudo aquillo que o povo tiver necessidade das quais terras elles ditos officiaes as darão de sua mão para o que bem lhes parecer [...]". (GLEZER, 1992)

O rocio, portanto, destinava-se ao atendimento das necessidades dos moradores, sendo elas de ordem urbana ou rural, servindo para construção de casas, abertura de chácaras, pastagens, criação de animais, plantações, pomares e também, fundamentalmente, para obtenção de água, para pesca, caça, coleta e demais usos relacionados à terra e à água.

A organização municipal no Brasil, como unidade administrativa, teve sua origem na organização do Estado português, no início do século XVII, através das Ordenações Filipinas, aplicadas na metrópole e em suas colônias. Essa ordenação vigorou, de fato, no Brasil, até meados da primeira metade do século XIX.

De acordo com Murillo Marx, as Ordenações Filipinas ${ }^{28}$ diziam que a elevação de uma povoação à categoria de vila ou cidade

“[...] significava atribuir à mesma uma jurisdição, que se estendia por um território denominado termo, além de direitos e distinções, sempre de acordo com o especificado no foral,

28. Segundo Afonso de Taunay, o Código Filipino era "o livro básico por onde se regia a sociedade paulistana quinhentista. Era em obediência às suas determinações que a edilidade da Vila de Piratininga compreendia um juiz ordinário, dois vereadores e um procurador de Concelho, assistidos de almotacel e alcaide." (TAUNAY, 2003, p.32) 
regulamento régio que determinava a criação/elevação de uma vila ou cidade e regulava todos os assuntos concernentes a sua administração, assim como aos direitos e obrigações de seus moradores". (MARX, 1991)

A administração desses núcleos, segundo Mônica Silveira Brito, era responsabilidade do Conselho, que acumulava funções legislativas, judiciárias, militares e tributárias, e era, em sua maioria, "composta por cidadãos eleitos entre e pelos chamados "homens bons"." (BRITO, 2007, p.56)

O Conselho tinha um patrimônio que correspondia a uma extensão territorial, o rocio, que era geralmente determinado por uma área de raio de meia-légua, ou 3.300 metros $^{29}$, em torno da área central da povoação. Essas terras deveriam atender, basicamente, a três funções.

A primeira é que elas deveriam ser concedidas aos moradores através das cartas de data. Através desse instrumento eram distribuídas, mediante solicitação dos interessados e a critério dos oficiais do Conselho, extensões territoriais do rocio, de dimensões variadas, de acordo com os usos e finalidades apresentados pelos solicitantes. (BRITO, 2007) Em São Paulo, em geral, as datas para edificação de casa e quintal tinham dimensões menores e eram concedidas gratuitamente. Já as terras destinadas à lavoura e criação eram maiores e geralmente eram concedidas ${ }^{30}$ mediante o pagamento de foros ou laudêmios ${ }^{31}$.

A segunda forma de concessão era

"[...] a de oferecer áreas que deveriam servir como logradouros públicos, isto é, campos de uso comum dos moradores, que os utilizavam para pastagem, retirada de madeira, abastecimento de água junto a nascentes; serviam também, quando à margem de rios

29. Até a adoção do sistema métrico, Brasil e Portugal utilizavam a légua como unidade de medida. Entretanto essa medida não era a mesma nos dois países sendo a légua portuguesa igual a 6.179,74m enquanto a légua Brasileira mede $6.600 \mathrm{~m}$. Assim, segundo Iraci del Nero da Costa, no Brasil, 1 légua $=3000$ braças $=6.000$ varas $=30.000$ palmos $=240.000$ polegadas $=660.000$ centímetros $=6.600$ metros. (fonte: FEA-USP)

30. Segundo Mônica Silveira Brito, "a validação das concessões dependia do cumprimento de certas obrigações em prazo predeterminado, como a de se dar o alinhamento e construir ou de se estabelecer cultura ou criação, ficando sujeitas à pena de comisso quando não cumpridas as cláusulas impostas no contrato de concessão."(BRITO, 2007, p.57)

31. O laudêmio é uma taxa que incide sobre transações com escritura definitiva de compra e venda de terrenos. 
ou ribeirões, para bebedouro de animais, lavagem de roupa, retirada de barro e areia para edificações; além disso, eram também considerados logradouros públicos as estradas, caminhos e passagens. Todas essas áreas deveriam permanecer livres da apropriação privada, para serem usadas por qualquer um que delas necessitassem, abertas a todos e a ninguém em especial" (BRITO, 2007, p.57).

Portanto, essas áreas não correspondiam exatamente ao conceito de espaço público que existe atualmente. Eram espaços de uso comum. Entretanto, a perenidade e garantia de uso dessas terras como áreas de uso comum eram estabelecidas pela frequência e intensidade de sua utilização, o que acabava por conferir a essas terras a condição jurídica de servidão. Como geralmente áreas destinadas à servidão não eram respeitadas, tornou-se comum que essas terras fossem cercadas passando, dessa forma, ao domínio privado. (BRITO, 2007)

A terceira é que o Conselho deveria garantir que nessas terras existissem locais destinados à construção de edifícios públicos ${ }^{32} \operatorname{como}$ forma de garantir o estabelecimento da povoação.

É importante perceber que essas formas de concessão particular se referiam unicamente à terra, permanecendo a água destinada exclusivamente ao uso comum sem possibilidade de concessão particular ainda que fosse possível cercar uma fonte que estivesse dentro de uma data de terra. Não havia menção oficial sobre como as águas dos córregos, fontes e rios da vila deveriam ser tratadas, restando para isso a interpretação individual das regras que determinavam a concessão de terras. A água estava, portanto, submetida à terra. Havia apenas uma consciência comum que determinava que as águas deveriam estar sempre livres e desimpedidas para servir os moradores da vila.

As áreas de uso comum tinham um importante significado econômico para o Conselho, já que a concessão do seu uso contribuía para

32. Como matadouros, hospitais, cemitérios e outros (BRITO, 2007, p.57). Ainda conforme Mônica Silveira Brito "muitas vezes as municipalidades não reservavam uma parcela de seu patrimônio para tais usos, precisando comprar terras de terceiros para realização de obras de interesse público, [...] alguns casos ocorridos na cidade de São Paulo: o teatro provincial, o seminário de educandos e o matadouro, cujos terrenos para sua construção precisaram ser desapropriados ou adquiridos por compra pela administração pública [...]. (BRITO, 2007, p.57) 
o incremento das rendas municipais por meio da cobrança de foros e laudêmios. $\mathrm{O}$ arrendamento de terras do rocio também era responsável por contribuir com o aumento da arrecadação. No período colonial, em que a economia paulista não se viabilizava, essa arrecadação, e portanto, a prática da concessão das áreas de uso comum, era considerada fundamental para a sobrevivência da organização municipal. Dessa forma o domínio particular se sobrepunha ao domínio comum.

É importante considerar que as áreas de uso comum eram responsáveis por manter, mesmo em uma sociedade escravagista, como era o caso de São Paulo, a relação de propriedade entre trabalho e os meios de produção, isto é, essas terras garantiam a manutenção da relação entre trabalho e a propriedade da terra e da água como meio de trabalho. Terra e água eram responsáveis pela subsistência dos moradores, ainda que sua economia estivesse inserida numa lógica de produção distinta, o mercantilismo colonial.

\section{A CONDIÇÃO DA ECONOMIA PAULISTA E A PRESENÇA DOS RIOS}

No fim do século XVI, São Paulo era um povoado com aproximadamente 750 habitantes e 150 casas. Do ponto de vista da economia, as atividades do núcleo se limitavam à existência de algum comércio baseado em importações e uma incipiente produção para exportação. A produção interna era restrita aos produtos que não eram importados da metrópole e acabava por se basear na produção para subsistência a partir da troca de gêneros com outros núcleos e na exploração das condições naturais locais.

No período colonial, a participação de São Paulo na vida econômica da metrópole era considerada secundária devido à predominância da produção de açúcar no nordeste baseada no sistema de plantações a partir de grandes propriedades e trabalho escravo negro. ${ }^{33} \mathrm{O}$ processo de colonização introduziu um sistema em que a produção colonial visava, predominantemente, a exportação como forma de incrementar a acumulação primitiva de capital na metrópole $e^{34}$.

33. PEREIRA, Paulo Cesar Xavier. Espaço, técnica e construção. São Paulo: Nobel, 1988.

34. Segundo Paulo Cesar Xavier Pereira, "a organização da economia colonial viabilizava o desenvolvimento do capitalismo industrial europeu e embotava a 
São Paulo sofria com piores condições de localização e competitividade, estando mais distante dos destinos finais dos produtos coloniais. Mesmo as condições de fertilidade do solo não eram as ideais. Além disso, a própria Serra do Mar aparecia como um obstáculo considerável para o acesso à vila e para o escoamento de produtos. Dessa forma a economia de São Paulo se caracterizava por condições de produção tecnicamente inferiores, e, por essa razão, praticamente desprezíveis. Mesmo do ponto de vista da absorção de produtos vindos da metrópole pelo mercado local, as condições não eram melhores. O pequeno número de habitantes em uma sociedade senhorial e escravagista com alta concentração de renda representava um mercado insignificante. (PEREIRA, 1988)

Em São Paulo, esse cenário também determinava as formas de apropriação do trabalho. A comercialização do escravo negro nessas condições também não fazia sentido. Para os padrões locais paulistas, o custo do negro africano era considerado muito elevado fazendo com que predominasse a utilização da mão de obra indígena. (PEREIRA, 1988)

São Paulo penava com a falta de estímulos e as atividades comerciais eram restritas a um mercado interno que apenas garantia a sobrevivência dos moradores da vila ${ }^{35}$. Nesse contexto de estagnação e inércia econômica, a povoação de São Paulo mal servia para garantir a ocupação do território.

Esse isolamento de São Paulo em relação ao movimento capitalista colonial determinou a forma que se deu o desenvolvimento das suas instituições sociais e políticas e também condicionou a sua economia

divisão do trabalho na Colônia ao permitir aqui uma acumulação de riquezas mas não de capital. Ela tornava possível o incremento do montante de capitaldinheiro sem que isso significasse uma alteração na forma básica da produção colonial fundada no trabalho escravo. Nos centros metropolitanos, do ponto de vista do capital mercantil em expansão, o controle monopolista da produção colonial identificava-se com o processo de separação do trabalho e da propriedade que lá estava ocorrendo, ambos voltados para a acumulação primitiva de capital." (PEREIRA, 1988, p.18-19)

35. "Desse processo de colonização depreende-se que a formação das instituições sociais, políticas e econômicas se dá enquanto expressão do desenvolvimento do capitalismo mercantil, manifestando-se aqui sobre a forma de grandes propriedades monocultoras baseadas no trabalho escravo. Por esse motivo é que o enquadramento paulista na ordem capitalista mundial tem raízes profundas na divisão internacional do trabalho e na estruturação regional da produção. A exploração colonial exigia um setor de exportação com grandes unidades produtivas à base do trabalho escravo dirigidas para o mercado europeu. (PEREIRA, 1988,p.18) 


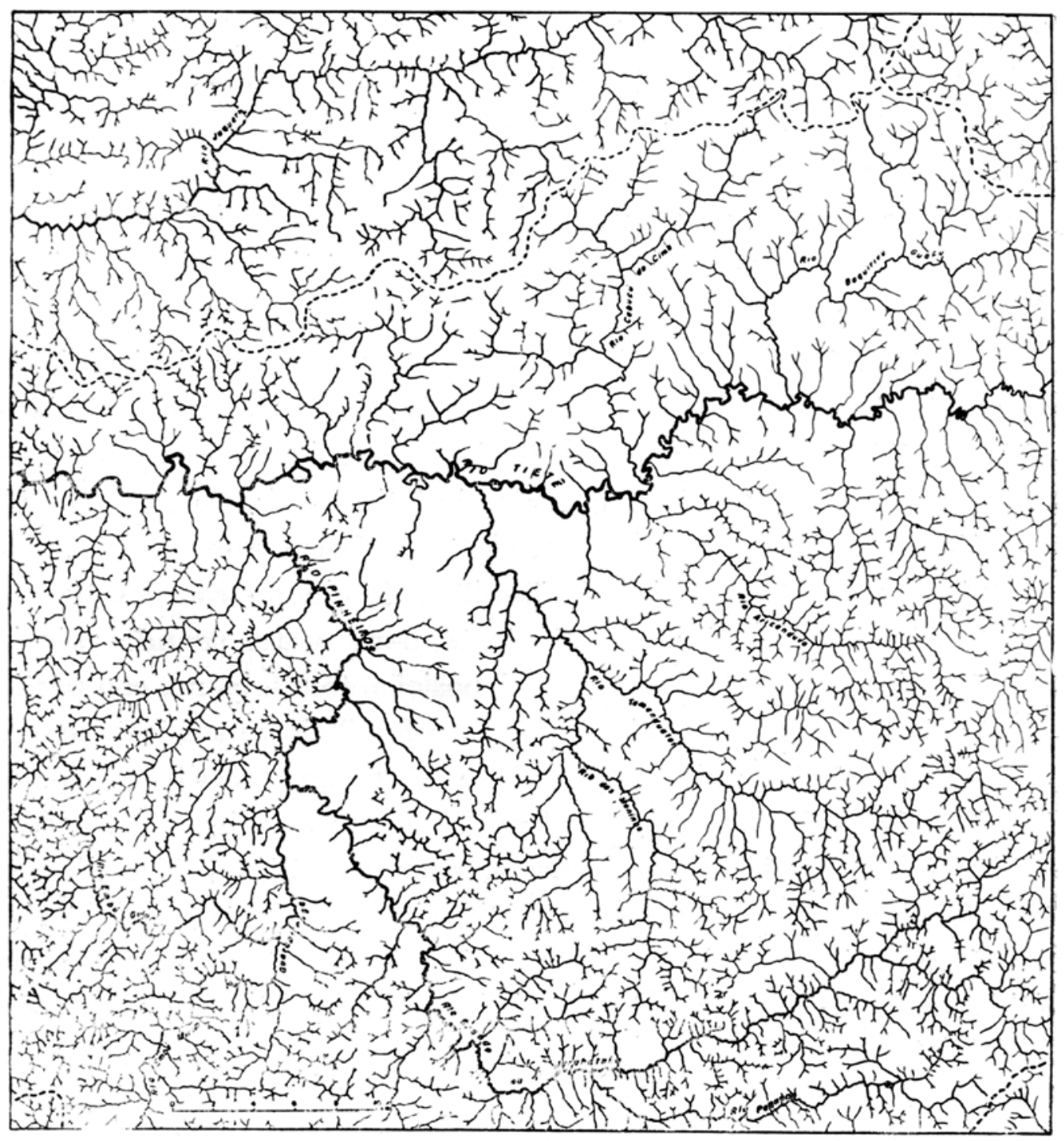


Rede de drenagem da região de São Paulo (baseada na Folha do Município da Capital - Comissão Geográfica e Geológica de São Paulo, s/d) a uma produção local, voltada, principalmente, para a manutenção da ocupação, ainda que se tenha buscado, em todo o período colonial, a inserção da economia paulista na lógica da reprodução do capital que se mundializava.

É nesse contexto que as condições físicas do sítio e os recursos naturais disponíveis, particularmente os seus rios, tem relevância. Dessa forma, cabe relacionar a escolha do local de fundação de São Paulo à existência de uma estrutura hídrica aqui existente e que deve caracterizar o uso dos rios e da água nesse período.

O local de implantação do colégio que fundou a vila de São Paulo, aponta para a importância dos rios Tamanduateí e Tietê. Esse local está posicionado em uma colina relativamente alta, na confluência do rio Tamanduateí e o seu afluente Anhangabaú. Elevada cerca de 25 metros das planícies inferiores, a colina é justamente o divisor de águas desses dois rios, oferecendo uma defesa natural por escarpas íngremes e várzeas largas, além de uma visão privilegiada da região. Um pouco mais ao sul da colina, estavam dois afluentes do Anhangabaú, o Saracura e o Bexiga. A presença de diversos corpos d'água ofereciam ao colonizador terras relativamente mais férteis ${ }^{36}$, além da pesca e navegação.

A escolha do sítio se deveu, principalmente, ao Tietê, rio mais importante da região, acessível pelo Tamanduateí, que era navegável por pequenas embarcações ${ }^{37}$. A escolha do sítio próximo ao Tietê se justifica-

36. A fertilidade das planícies aluviais que cercavam a vila era relativa já que o solo da região como um todo era pobre. "Explica-se a escolha pela existência aí de uma imensa clareira natural na floresta que revestia o território paulista: são os Campos de Piratininga. A falta de arborização neste sítio explica-se pela formação do terreno, constituído de depósitos flúvio-lacustres terciários argilosos que dão um solo pobre. Não se desenvolveu nele por isso nenhum tipo vegetativo de porte e denso, e a floresta natural que cobria os terrenos graníticos e cristalinos que se sucedem desde a Serra do Mar interrompe-se aí para dar lugar a um vasto descampado." PRADO JÚNIOR, Caio, A cidade de São Paulo: geografia e história / Caio Prado Jr. Coleção: Tudo é História. São Paulo: Brasiliense, 1998, p.13. Já Affonso de Taunay, citando Simão de Vasconcelos afirma que "os campos da região piratiningana eram bastante férteis em searas de trigo e grandes vinhas. [...] De algodoais, de culturas de fumo e apesar do clima até canaviais". (TAUNAY, 1953, p.185)

37. Mesmo a navegabilidade dos rios de São Paulo pode ser discutida já que "embora não se trate de rios muito favoráveis à navegação, ainda assim eles representam a melhor e mais utilizada via de comunicação. Não só para as grandes expedições de reconhecimento e exploração do interior, as entradas e bandeiras, mas também, e é isto o principal, para o intercâmbio das populações que se es- 
va devido à sua extensão dentro da Capitania de São Paulo e pelo fato de suas águas correrem para dentro do continente, conectando o planalto ao interior e, eventualmente, aos rios Paraná e Prata. O Tietê era o eixo natural de circulação do sistema hidrográfico do planalto. Por essa característica, o rio Tietê contribuiu para a origem de vários outros núcleos na região. Partindo de São Paulo, a ocupação do planalto segue o sentido do rio, onde nas suas margens logo apareceram as primeiras povoações ${ }^{38}$.

No fim do século XVI, Teodoro Sampaio anota que, "embarcados em sua canoa, o padre, o negociante, o fazendeiro, o simples homem do povo podiam atingir qualquer ponto dentro da zona povoada em torno de São Paulo." 39 Ainda segundo Teodoro Sampaio,

“[...] navegava-se bem sobretudo pelo Tamanduateí, podendose por ele alcançar a Borda do Campo, como descer ao Tietê, ao "pôrto", e daí, rio acima ou rio abaixo, chegar aos bairros ou aos sítios, quase todos acessíveis por água." (BRUNO, 1991, p.211)

O Tietê, portanto, foi o responsável pela escolha do local de fundação da vila devido ao interesse do colonizador no seu significado econômico. A presença abundante de água dentro e próximo da vila, além do sentido de defesa e transporte, representava a possibilidade de se exercer a pesca, a caça, a coleta, além da ingestão da água, atividades que caracterizavam o uso dos rios. Essas características do sítio puderam ser melhor exploradas com o estabelecimento da povoação.

A evolução da ocupação do planalto paulista, tendeu a favorecer São Paulo como seu centro, o que pode ser explicado pelos caminhos e estradas que se consolidaram, no século XVIII, como rotas comerciais que passavam pelo núcleo colonial. A estrutura geográfica combina rede

tabelecem no planalto. E é para gozar das vantagens destes caminhos naturais e de fácil acesso que o povoamento procura no início, de preferência e quase exclusivamente, a margem dos rios." (PRADO JR, 1983, p.21)

38. Povoações como Nossa Senhora da Expectação do Ó (hoje Freguesia do Ó) e Parnaíba a jusante e Guarulhos, Itaquaquecetuba, São Miguel, Mogi das Cruzes a montante. Indiretamente, pelo rio Pinheiros, seu afluente a jusante do núcleo de São Paulo, essa característica se mantém, abrigando aldeias indígenas e povoações jesuíticas como Pinheiros, Itapecerica, Ibirapuera (atual Santo Amaro). Também em afluentes do Pinheiros, como o Jeribatiba (atual rio Grande), Mbói-Mirin e Cotia. (PRADO JR, 1983)

39. BRUNO, Ernani Silva. História e Tradições da cidade de São Paulo: vol.ı Arraial de Sertanistas (1554-1828). São Paulo: Hucitec, 1991, p.209.

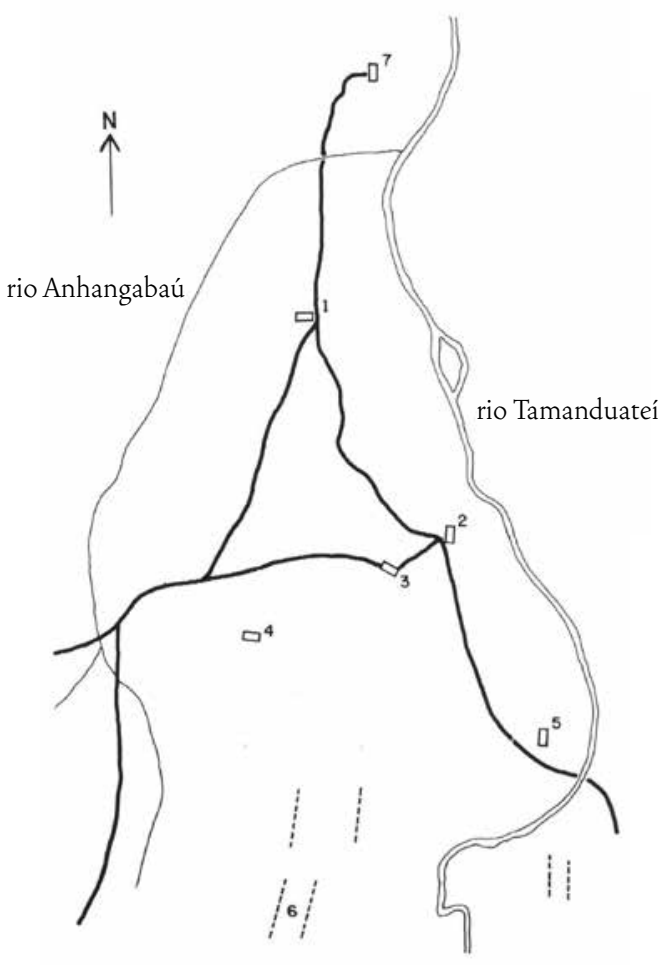


São Paulo de Pitatininga em 1560

(fonte: Affonso de Freitas)

1. Residência de Tebiriça (atual largo de São Bento)

2. Igreja do Colégio (atual pátio do Colégio)

3. Igreja Matriz (atual praça da Sé)

4. Casa do Senado (atual largo São Francisco)

5. Residência de Caauby (morro cujo arrastamento terminou em 1874)

6. Morro da Forca (atula largo da Liberdade) 7. Primitiva Aldeia de Tebiriça (Posteriormente morro dos Lázaros) hidrográfica e relevo, conferindo a São Paulo a condição de centro do povoamento do planalto, dando sentido a esses caminhos e estradas ${ }^{40}$.

O mapa da página 56 mostra a condição original dos rios de São Paulo, marcada pela abundância de córregos e rios, ainda que o volume da água disponível variasse com os períodos do ano, intercalando cheias e estiagens.

Utilizando uma estrutura de caminhos e trilhas e, considerando a presença dos rios e da água, edificaram, jesuítas e indígenas, as primeiras construções do núcleo com extrema simplicidade material, dando maior relevância à sua implantação em relação à colina e à organização interna da ocupação. Esses caminhos, que ligavam diversos núcleos da região se refletiam na própria estruturação da vila que, limitada às escarpas da colina e circundado pelo Anhangabaú e Tamanduateí, formou o chamado triângulo ${ }^{41}$. A estrutura do triângulo pode ser observada no mapa da página 58. Os caminhos e estradas se refletiam na própria estruturação do núcleo e se conectavam ao arruamento da vila marcado pelo triângulo. ${ }^{42}$

40. Para sudoeste, a estrada que leva a Sorocaba, Itapetininga e Guarapuava. Para oeste, a estrada do vale do rio Tietê, na direção de Mato Grosso, com Parnaíba, Itu, Porto Feliz, Tietê, Piracicaba e Araraquara. Para o norte, o Caminho dos Guaiases, que por Jundiaí, Mogi Guaçu e Mogi Mirim, se chega nas minas de Goiás e Triangulo Mineiro. Também para o norte, o caminho para o sul de Minas, por Atibaia e Bragança. Para nordeste, a estrada que leva ao vale do rio Paraíba do Sul por Mogi das Cruzes, São José dos Campos, Taubaté, Pindamonhangaba, Lorena, na direção do Rio de Janeiro. De todas essas estradas, a de Santos, o Caminho do Mar, sempre foi a mais importante mesmo com a Serra do Mar erguendo-se entre o planalto e o litoral. (PRADO JR, 1983, p.26-27)

41. Para Núcleo central formado pelas ruas Direita de Santo Antônio (hoje Direita), do Rosário (alterada para Imperatriz e com a República para 15 de Novembro)e Direita de São Bento (atual São Bento). O triangulo também é organizado por seus vértices, onde estão situados os edifícios dos conventos de São Francisco, São Bento e Carmo (TOLEDO, 2004, p.9).

42. Pelas ruas Brigadeiro Tobias e Florêncio de Abreu chegava-se aos caminhos no norte, cruzando o Anhangabaú e mais adiante o rio Tietê. Para leste, cruzando o Tamanduateí, a estrada que levava aos núcleos do Vale do Paraíba. Para o sul, três caminhos. Pelo eixo do divisor de águas do Anhangabaú e Tamanduaté, apareceria a rua da Liberdade e sua continuação, rua Vergueiro. Outra, a partir do fundo do vale do Anhangabaú, no ponto onde encontrava seu afluente, Saracura, surgiria o caminho que hoje é a rua Santo Amaro e sua continuação, avenida Brigadeiro Luís Antônio. Ainda outra para o sul, cruzando o ribeirão Anhangabaú, a atual rua da Consolação, por onde se acessava os núcleos de Pinheiros, Embu, Itapecerica e Santo Amaro além de Parnaíba, Porto Feliz e Sorocaba mais adiante. (PRADO JR, 1983, p.65-67) 
A existência de inúmeras tribos indígenas nessa região ${ }^{43}$ certamente concorreu para a determinação do local de fundação. Em São Paulo, o emprego do escravo africano não foi significativo como em outros centros da colônia, sendo mais utilizado o trabalho do indígena.

Dessa forma, as primeiras construções de São Paulo se caracterizaram pelo emprego da mão de obra indígena e determinaram o aspecto da vila nos primeiros anos da ocupação. O emprego do trabalho indígena cobria todos os aspectos do cotidiano de São Paulo, sendo eles responsáveis pela coleta de água nos rios e fontes e também na atividade de construção. Já nas primeiras edificações, o trabalho indígena estava presente, assim como descreveu José de Anchieta:

"Desde janeiro até o presente, estivemos às vezes mais de vinte numa casa pobrezinha, feita de barro e paus, e coberta de palha, de 14 passos de comprimento e 10 de largura, que é ao mesmo tempo escola, enfermaria, dormitório, refeitório, cozinha e despensa... Esta casa construíram-na os próprios índios para nosso uso, mas agora preparamo-nos para fazer outra um pouco maior, de que nós seremos operários com suor de nosso rosto e auxílio dos índios." 44

Segundo Affonso de Taunay, no final do século XVI, o abastecimento de água de São Paulo se baseava em "poços quintaleiros" e "para fins de bebida, de nascentes brotando no recinto da vila." (TAUNAY, 1953, p.18) Teodoro Sampaio ${ }^{45}$ descreveu a presença da água na São Paulo seiscentista como "abundante e salutífera". Segundo esse autor,

43. "Concorre outra circunstância, esta de natureza econômica, que impulsiona o povoamento do planalto. São as numerosas tribos indígenas aí estabelecidas e que apresentam aos colonos um farto abastecedouro de mão-de-obra. Como se sabe, é em larga escala ao braço do índio, antes da introdução do negro africano - e em São Vicente por muito tempo ainda - que recorre inicialmente a colonização. (PRADO JR, 1983, p.10)

44. Em carta dirigida ao Pe. Inácio de Loyola em $1^{\circ}$ de setembro de 1554, citada por Paulo Cesar Xavier Pereira (LEITE, Serafim. Cartas dos primeiros jesuítas no Brasil. Comissão do IV Centenário de São Paulo, São Paulo, 1956, v.2 apud PEREIRA, 1988, p.17).

45. SAMPAIO, Teodoro. São Paulo no tempo de Anchieta, p.34 apud BRUNO, 1991, p. 278 . 
"[...] fontes numerosas, na encosta dos morros e nos desbarrancados para onde davam os quintais, forneciam o suficiente para as obras e os gastos domésticos. [...] O acesso para as águas dos ribeiros no perímetro da cidade nascente era difícil. Mas bem se escusavam águas do rio descendo encostas íngremes ou talhadas em degraus onde tão abundantes eram os olhos e as minas de água." (TAUNAY, 1953, p.18)

Ernani Silva Bruno alerta para o fato de que os documentos "quinhentistas e seiscentistas" que registram o abastecimento de água da vila nesse período não dão a ideia de que esses olhos d'água fossem tão numerosos quanto na descrição acima. Entretanto, afirma que os habitantes da vila se abasteciam em algumas fontes e em um "ribeiro". (BRUNO, 1991, p.279)

Ainda segundo Affonso de E. Taunay, as Atas da Câmara registram que as fontes que brotavam na vila, numerosas ou não, eram muito utilizadas pelos moradores sendo responsáveis pelo abastecimento e subsistência do povoado. Sobre as fontes,

“[...] uma corria para o Tamanduateí, sendo a outra de localização difícil, pois sabe-se apenas que nascia "detrás das casas de Joanne Annes". Como todos os moradores recorriam a elas, formavam-se em seus locais ajuntamentos enormes de índios e índias, carregando vasilhame de tôda espécie." (TAUNAY, 1953, p.18)

Além de indicar a ampla utilização das águas de nascentes, essa observação de Taunay evidencia a presença do indígena nas atividades relacionadas à água e ao abastecimento da vila. É possível supor que, se todos os moradores se utilizavam dessas fontes e as aglomerações eram de índios e índias, a mão de obra dos chamados "negros da terra" era muito usada para esses fins.

Segundo Laima Mesgravis ${ }^{46}$, o conteúdo das Atas de Câmara desse período deve ser relevado, principalmente no que diz respeito ao trabalho indígena, já que era importante para a Câmara

46. MESGRAVIS, Laima. Afonso de Escragnolle de Taunay, o historiador de São Paulo in TAUNAY, Afonso de Escragnolle. São Paulo nos primeiros anos: 15541601. São Paulo no século XVI. São Paulo: Paz e Terra, 2007. 
“[...] ocultar das autoridades o caráter ilegal e violento de muitas atividades dos bandeirantes. Daí as inúmeras sessões abertas e encerradas sob a alegação de que nada havia para decidir; as referências críticas à ausência de vereadores às sessões mensais obrigatórias, a pretexto de que estavam "no sertão buscando remédio para sua pobreza". Era uma forma de ocultar o apresamento dos índios, proibido a partir de 1570 a menos que fosse para fazer "guerra justa", o que exigia a comprovação de ataque injustificado aos brancos através de consulta às autoridades superiores da Capitania ou da Colônia." (MESGRAVIS, 2003, p.5)

Em outra descrição, Taunay afirma que uma dessas fontes presentes na vila funcionava "provavelmente por meio de algum aqueduto tôsco ou quiçá de um rêgo aberto no solo" onde se juntavam escravos carregadores. "Esses locais eram "centros de aglomeração de gente de toda espécie - mas sobretudo de escravos e de escravas [...]". (BRUNO, 1991, p.279280)

Essa observação de Taunay nos permite afirmar que há também a utilização de mão de obra escrava negra nas atividades de abastecimento de água em São Paulo nesse período.

Dentro da economia colonial, a utilização do trabalho do negro africano tinha alguns significados. No caso de São Paulo, esses significados distinguem da utilização da mão de obra indígena da negra africana.

A imposição do trabalho escravo africano dizia respeito à produção das principais mercadorias coloniais. $O$ trabalho compulsório era uma imposição do sistema como forma de evitar que o produtor direto simplesmente se apropriasse de uma porção de terra despovoada e se tornasse um produtor independente dos mecanismos coloniais. Da mesma forma, o trabalho livre poderia representar assalariamento e obtenção de renda que também significaria diminuição da lucratividade do empreendimento colonial. "Numa terra livre, impunha-se o trabalho cativo [...]". (PEREIRA, 1988, p.25).

Para o comprador, o preço do escravo era definido pelo retorno futuro do investimento de capital que ele fazia na compra. Era um cálculo antecipado com vistas a um ganho futuro. Para o traficante, o preço era formado pelos custos do aprisionamento e do transporte, sobre os quais era acrescido um lucro. $O$ traficante sempre buscava localidades da colônia onde havia uma maior articulação com o mercado, possibilitando 
assim a obtenção de maior lucro na venda.

"O investimento na compra do escravo significa um custo fixo para seu proprietário. Por outro lado, trabalhasse ou não, os custos de sua manutenção tinham que ser despendidos. Por isso, no intervalo das atividades produtivas ligadas diretamente à exportação, o trabalho do escravo era utilizado em outras atividades, tais como na abertura de novas terras para exploração, nas obras de construções e em diversos melhoramentos na propriedade. Esse trabalho acumulado à margem do trabalho produtivo para economia agroexportadora, embora significasse um aumento da riqueza do senhor, não constituía um fluxo de renda monetária."(PEREIRA, 1988, p.27)

A partir das observações de TAUNAY (1953) e PEREIRA (1988) e, compreendendo o contexto e a inserção da vila de São Paulo no sistema colonial, podemos incluir nas atividades descritas acima, atividades como a coleta de água em rios, fontes e bicas, assim como os despejos de águas servidas nos rios, como atividades realizadas por escravos.

Segundo José de Souza Martins,

"[...] a escravidão colonial definia-se [...] como uma modalidade de exploração da força de trabalho baseada direta e previamente na sujeição do trabalho, através do trabalhador, ao capital comercial. [...] o proprietário espera extrair do seu escravo um rendimento econômico que é medido pelo lucro médio, que deve ao menos equivaler ao rendimento que seu dinheiro lhe daria se fosse aplicado em outro negócio. A exploração do escravo no processo produtivo já está, pois, precedida de parâmetros e relações comerciais que a determinam. Essa exploração não abrange apenas o lucro médio, mas também a conversão de capital em renda capitalizada, a parcela do excedente que o escravo pode produzir e que é antecipadamente paga ao mercador de escravos." 47

Dessa forma, tanto o valor do investimento feito na compra do escravo como o valor aplicado na sua manutenção, "assumem uma aparência

47. MARTINS, José de Souza. O cativeiro da terra, São Paulo: Livraria Editora Ciências Humanas, 1981. 
que permite identificá-los como capital" (PEREIRA, 1988, p.28), já que podem ser confundidos com capital fixo e variável, assim como no custo de aquisição e manutenção de uma máquina, por exemplo. Entretanto, o dinheiro aplicado na compra do escravo não funciona como capital e o custo de manutenção são apenas gastos necessários à "sobrevivência" do capital-dinheiro investido na sua compra. (PEREIRA, 1988)

Mesmo em um setor da produção considerado marginal, é importante estabelecer o significado econômico e social do emprego de mão de obra nas atividades que envolviam os rios e as águas de São Paulo ${ }^{48}$. Trata-se de determinar como a água e os rios passaram a integrar os processos de produção de valor a partir do trabalho.

Já nos primeiros anos da ocupação, essas atividades eram intermediadas por trabalho cativo, ainda que a água estivesse presente e plenamente acessível na vila, podendo ser usada livremente por qualquer pessoa, escrava ou livre. A água dos rios era responsável pela subsistência de todos que viviam na povoação.

Ainda sobre a notação de Taunay a respeito da precariedade dos locais onde se conseguia água, nos interessa pontuar que, ainda que se tivesse, por parte do colonizador, a nítida noção da importância da água para a manutenção da povoação, essa falta de zelo pela água e pelos espaços da água parece estar envolvida com a característica fundante em São Paulo de favorecer a sobreposição e a priorização do domínio particular sobre o comum. O desprezo pelas atividades e estruturas que envolvem os domínios comuns em geral, e as infraestruturas urbanas e a água em particular, se inicia a partir desse momento e marcará toda a história de São Paulo.

As descrições de Taunay apontam ainda para a convivência simultânea da utilização da mão de obra livre, escrava negra e indígena. Nesse sentido, segundo Xavier Pereira:

48. "Antes de tudo, o trabalho é, fundamentalmente, um processo entre homem e Natureza. A ação do homem é uma mediação da sua relação com a Natureza. Ele se apropria da matéria natural colocando em movimento suas próprias forças naturais pertencentes à sua corporalidade. $\mathrm{O}$ homem desperta as potências adormecidas da Natureza sujeitando-a ao seu domínio. O produto dessa ação é uma matéria natural adaptada às necessidades humanas mediante modificação da forma. Portanto, o trabalho funde-se ao objeto de trabalho. A terra é o meio universal de trabalho, ela é o lugar onde o homem fica, onde ele está, ela oferece as matérias naturais e simultaneamente é o seu campo de ação." (MARX, 1985a, p.149) 
"A verdade é que o índio, oscilando entre a condição de "administrado" e a de liberto, era colocado numa situação que possibilitava maiores ganhos aos que se apropriassem de seu trabalho. [...] O índio podia ser um trabalhador liberto, mas nunca um homem livre. O trabalho do homem livre convivia, necessariamente, com o trabalho escravo. $O$ funcionamento da economia colonial assentada na escravidão não dispensava o trabalho livre. As singularidades dessas duas categorias de trabalho tornaram-se mais claras quando as exigências impostas pelo desenvolvimento da divisão do trabalho expandiu as atividades livres, sem significar, contudo, incompatibilidade com a manutenção da ordem escravocrata." (PEREIRA, 1988, p.39-40)

Portanto, as atividades relacionadas ao abastecimento da vila eram marcados pela presença tanto do escravo negro quanto do índio, assim como de trabalho livre, sem haver incompatibilidade. As particularidades do emprego de cada uma dessas categorias ficariam mais claras com o avanço e desenvolvimento da divisão do trabalho.

Embora tanto a mão de obra escrava quanto a indígena estivessem sujeitas ao colonizador, a sua integração aconteceu de forma distinta:

"Enquanto os ganhos com o apresamento dos indígenas ficavam na Colônia, os referentes ao tráfico dos negros constituíam-se num importante setor do comércio colonial, apontando a integração diferenciada do comércio colonial e a diferença fundamental entre utilização do trabalho compulsório do índio e do negro. Esta diferença particulariza a região paulista no contexto da Colônia."(PEREIRA, 1988, p.19)

O apresamento do indígena, portanto, se configurava como um negócio da colônia, fazendo com que os rendimentos obtidos com a sua utilização permanecessem na colônia, por assim dizer, no bolso do colono em São Paulo. Por outro lado, os rendimentos obtidos com a comercialização do negro africano eram destinados à metrópole.

Em São Paulo, assim como foi observado, não havia dificuldades para se apropriar de terras. Para isso era apenas necessário pagamento de foro à Câmara. Como a terra sem trabalhador nada significava, a maior dificuldade estava em conseguir o trabalhador. É por isso que, em São Paulo, "o indígena administrado significava mais que a propriedade 
imóvel". (PEREIRA, 1988, p.23)

Portanto, é a partir da apropriação da terra, simultaneamente à apropriação do trabalho, que o sentido da exploração colonial se impunha aos moradores de São Paulo. Essa é a lógica que leva o colonizador à submeter o indígena e se apropriar de suas terras.

"É através desta disputa pela propriedade do trabalho que o morador de São Paulo, como agente colonizador, submete o índio e toma suas terras. O sentido da exploração colonial impunha a simultaneidade da apropriação da terra e a utilização do trabalho cativo. [...] Esta imposição na economia paulista caracterizava-se pela importância primordial que assumia a apropriação do trabalho indígena em relação à apropriação da terra. [...] Essas terras, para terem algum significado, tinham que, além se ser férteis, estar numa localização favorável à comercialização dos seus produtos e, principalmente, ser trabalhadas. A propriedade da terra como propriedade imóvel, ou seja, como condição prévia de produção, não tinha significado econômico [...]" (PEREIRA, 1988, p.26)

A terra sem trabalhadores, sejam índios ou escravos, não tinha qualquer significado econômico. Em São Paulo, essa condição da economia garantia, de certa forma, a preservação do patrimônio do Conselho e as terras de uso comum.

Dessa forma, as atividades de coleta e despejo configuravam formas de apropriação dos rios e das águas em São Paulo. A intermediação do trabalho nessas atividades conferia a esses recursos um valor de uso e não somente o uso. Ainda que a água não tivesse propriamente um valor de troca, pois era abundante, é a lógica da exploração econômica das coisas que passava a se sobrepor ao uso dos recursos, da água e do rio, motivando a apropriação privada desses recursos e a ampliação dos domínios particulares. A água extraída da fonte, transportada e distribuída pelo trabalho do indígena ou do negro, transformava-se em meio de trabalho. Segundo Karl Marx,

“[...] a terra (que do ponto de vista econômico inclui também a água), como fonte original de víveres e meios já prontos de subsistência para o homem, é encontrada sem contribuição dele, como objeto geral do trabalho humano. Todas as coisas 
que o trabalho só desprende de sua conexão direta com o conjunto da terra, são objetos de trabalho preexistentes por natureza. Assim o peixe que se pesca ao separá-lo de seu elemento de vida, a água, a madeira que se abate na floresta virgem, o minério que é arrancado de seu filão. Se, ao contrário, o próprio objeto de trabalho já é, por assim dizer, filtrado por meio de trabalho anterior, denominamo-lo matéria-prima. Por exemplo, o minério já arrancado que agora vai ser lavado. Toda matéria -prima é objeto de trabalho, mas nem todo objeto de trabalho é matéria-prima. O objeto de trabalho apenas é matéria-prima depois de já ter experimentado uma modificação mediada por trabalho." ${ }^{49}$

Ainda que a característica do uso da água e dos rios continuasse predominante, a condição desse recurso lentamente se transformava, submetida à terra e a partir da intermediação do trabalho. A água dos rios como um bem comum passava a integrar os domínios de apropriação privada.

A opção pela utilização das nascentes e fontes pela maior parte dos moradores da vila também acontecia pela sua proximidade, o que garantia um considerável conforto aos moradores. Essas águas vertiam dentro da própria colina, não sendo necessário se deslocar até os rios, nas cotas mais baixas, para a obtenção de água. Assim, desde muito cedo, esses locais se tornaram pontos de aglomeração e, segundo Ernani Silva Bruno, "logo se tornaram locais imundos" (BRUNO, 1991, p.278).

Isso fez com que a municipalidade passasse a olhar as fontes e bicas, como locais passíveis de aplicação de regras e controle, colaborando para determinar a forma de atuação das instituições municipais, determinando como esses espaços eram percebidos. A forma de resolver a questão da imundície, física e moral, nas fontes era a proibição de acesso.

Logo em 1576 a Câmara aplicava medidas contra qualquer "rapaz" que estivesse na fonte "pegando em alguma negra"50. Em 1590 seria multada "qualquer pessoa, branco ou negro, macho, encontrada nas fontes ou lavadouros" ou "qualquer pessoa que fosse à fonte não tendo lá o que fazer" ${ }^{11}$ e em 1613 a Câmara determinava que "nenhum homem nem

49. MARX, Karl. O Capital: Crítica da Economia Política, vol.. Livro Primeiro: O Processo de Produção do Capital, Tomo 1. São Paulo: Abril Cultural, 1985a, p.150.

50. Atas da Câmara da Vila de São Paulo, I, p.95 apud BRUNO, 1919, p.280.

51. TAUNAY, Afonso de E. São Paulo nos Primeiros Anos, p. 116 apud BRUNO, 
mancebo, de quinze anos para cima, fosse às aguadas e fontes da vila" ${ }^{2}$.

Além de revelar a preocupação em manter livres de sujeira e contaminação as águas que serviam os moradores, essas determinações da Câmara também revelam a necessidade de controlar esses espaços, onde a "imoralidade" se manifestava. Assim como o rocio, uma área de uso comum, se tornava uma área de controle direto da Câmara, o mesmo acontecia com os rios, com a água e os espaços da água.

Os dejetos coletados nas casas eram despejados diretamente nas margens dos rios Anhangabaú e Tamanduateí, atividade realizada pelos próprios moradores, por escravos negros e índios ${ }^{53}$. Desde muito cedo também, foi registrado a presença de dejetos que se acumulavam nas margens desses rios, principalmente nas do Tamanduateí, o que representava um nível pequeno, porém perceptível de poluição.

Dessa forma, nos primeiros séculos da povoação, as atividades relacionadas à água, seja abastecimento ou despejo, estavam caracterizadas pelo emprego de mão de obra cativa, predominantemente negra e indígena.

Portanto, a partir da sua condição de bem comum, onde o uso da água era a sua principal característica, os rios de São Paulo passaram a comportar a intermediação de trabalho em atividades de subsistência, contribuindo para a transformação do significado desses recursos.

1919, p.280.

52. TAUNAY, Afonso de E. História Seiscentista da Vila de São Paulo, IV, p.198 apud BRUNO, 1919, p.280.

53. Segundo Sant'Anna, a coleta de água e o despejo das águas servidas nos rios era uma tarefa desempenhada por escravos, trabalhadores pobres e crianças. Por essa razão eram personagens comuns em rios, reservatórios, bicas e chafarizes. (SANT'ANNA, 2007, p.71) 


CAPÍTULO 2 - TRABALHO LIVRE, PRIMEIRA REDE DE ÁGUA E CHAFARIZES: LUTAS PELO CONTROLE E POSSE INDIVIDUAL DA ÁGUA

No final do século XVI, na ocasião da outorga do rocio à vila, o Governador Geral, D. Luiz de Sousa transferiu-se para São Paulo acompanhado de uma equipe de profissionais - dois mineradores, um cirurgião e um ou dois engenheiros florentinos - para colocar em prática um projeto político e econômico que visava a melhoria das condições econômicas dessa região da colônia a partir da mineração, incentivando a população do sertão à busca do ouro.

Nesse momento, São Paulo contava com apenas 300 habitantes distribuídos em cerca de 4 hectares. Uma vila modesta e pouco densa se comparada aos 5 hectares construídos de Salvador, ocupados por uma população de 2.000 habitantes. Os muros que cercavam a vila acabavam de ser ampliados, e confinavam o núcleo arruado dentro de uma pequena porção da colina $a^{54}, \mathrm{o}$ triângulo, fazendo com que a área dentro do raio de 3.300 metros do rocio se configurasse como uma vasta porção de terras em torno da povoação. (BRITO, 2007)

54. Segundo Mônica Silveira Brito, "a área murada corresponderia aproximadamente àquela circunscrita ao perímetro criado pelas atuais ruas do Tesouro, XV de Novembro, Álvares Penteado, Largo da Misericórdia, Direita, Quintino Bocaiúva, cruzando a José Bonifácio, seguindo pelo eixo da rua Direita de trás da Sé com a de Santa Teresa, até o Pátio do Colégio." (BRITO, 2007, p.75, nota 25) 
Durante quase todo o período colonial, os arredores da vila edificada de São Paulo abrigavam as propriedades rurais que não ocupavam um perímetro muito extenso. Eram compostos por pequenas e médias propriedades formadas a partir de concessões reais ou aforamentos. Os limites das propriedades em São Paulo ficaram indefinidos durante quase todo esse período, quando era possível se apropriar de terras a qualquer momento. Essa situação se devia, basicamente, ao fato de a vila não se envolver com a grande produção colonial. Assim, suas terras permaneciam com pouco valor e sendo distribuídas a quem as solicitasse à Câmara.

A estrutura social e econômica da colônia se organizava visando a manutenção da relação de dominação colonial. As grandes inversões exigidas pela colonização só encontravam uma efetiva rentabilidade na organização de grandes empresas produtoras. Essa produção se fundamentava em grandes propriedades monocultoras baseadas em trabalho escravo, visando a exportação para o mercado europeu. ${ }^{55}$

O fato de o trabalho escravo dominar a estrutura produtiva da colônia não foi um impedimento para que o trabalho corporativo trazido da metrópole se organizasse. Essas formas de trabalho puderam conviver simultaneamente, ainda que as organizações de ofícios tivessem seu desenvolvimento constantemente impedido pela predominância do trabalho escravo. Em São Paulo, esse quadro se agravava devido ao seu isolamento da estrutura produtiva colonial. Isso significa que o trabalho livre, ainda que muito incipiente, estava presente no esquema produtivo, ligado a pequenas estruturas na geração de renda para subsistência. $O$ preço do escravo impedia o uso do trabalho do cativo na estrutura de produção paulista, quadro que somente seria modificado, no século XIX, com o ingresso do cultivo do café como forma de produção de riqueza. Dessa forma, o estado da economia de São Paulo não permitia que o colonizador abrisse mão do emprego do trabalho indígena, que predominava. Esse quadro não se alterou nos séculos XVI e XVII, até meados do século XVIII. (PEREIRA, 1988)

A Câmara Municipal tentava regulamentar alguns ofícios para garantir a sobrevivência da ocupação. Entretanto, os esforços para regular preços e garantir a qualidade do trabalho não foram suficientes para o desenvolvimento de organizações artesanais de trabalho que permaneceram extremamente modestas durante todo o período colonial, nos

55. PEREIRA, Paulo Cesar Xavier. Espaço, técnica e construção. São Paulo: Nobel, 1988. 
primeiros séculos de existência da vila. (PEREIRA, 1988)

Os dados estatísticos dos primeiros séculos de São Paulo, apesar de muito restritos, permitem descrever a vila no século XVI com pouquíssima atividade comercial ligada à atividade de artesãos: carpintaria, sapataria, ferraria, alfaiataria, olaria e tecelagem. Nesse momento essas atividades, pouco desenvolvidas, eram exercidas de forma irregular, sendo que esses artesãos, provavelmente exerciam outras atividades concomitantemente. A divisão do trabalho, ainda pouco desenvolvida, acarretava em uma baixa especialização das atividades que também se refletia nos próprios locais de trabalho que coincidiam com os locais de moradia. (PEREIRA, 1988)

Os resultados da implementação da política de incentivo à atividade mineradora tornaram-se perceptíveis a partir da descoberta de ouro em Minas Gerais em 1693. A vila de São Paulo foi elevada à condição de sede do Governo da Capitania em 1765, sendo que, um pouco antes disso, em 1711, fora elevada à condição de cidade. Esse fatos, além das descobertas de ouro em Goiás, em 1725, e no Mato Grosso, em 1734, implicaram certo crescimento populacional da cidade. ${ }^{56}$

A busca pelo enriquecimento através da mineração impôs dificuldades ao desenvolvimento da produção local, que dificilmente passava da produção para subsistência. A atividade mineradora em Minas estimulou, em São Paulo, a atividade de fornecimento de muares para o serviço de transporte nas regiões mineradoras.

No início do século XVIII a população chegava a 1.000 habitantes que ocupava cerca de 210 edifícios. Esse modesto incremento da população e a maior movimentação da economia devido ao início do ciclo do ouro possibilitaram um incremento, ainda que mínimo, no número de artesãos e uma maior diversidade de atividades na cidade.

Foi nesse período que, a partir da iniciativa do Governo Provincial, a atividade agrícola paulista passou a receber algum estímulo, ainda que modesto, desenvolvendo com maior eficácia o cultivo da cana-de-açúcar no interior.

Dessa forma, a partir da metade do século XVIII, São Paulo ganha relativa autonomia e importância dentro da colônia. Isso coincide com

56. BRITO, Mônica Silveira. Modernização e tradição: urbanização, propriedade da terra e crédito hipotecário em São Paulo na segunda metade do século XIX. 2007. Tese de Doutorado apresentada ao Departamento de Geografia da FFLCH-USP, 2007 , p.76. 
o momento em que se passa a investir na construção de edificações como forma de fortalecer a imagem da cidade ${ }^{57}$. As construções faziam presente o Governo Metropolitano e justificavam a cobrança de forais, rendimento que tinha importância no contexto da colonização. Através de regulações para edificações e manutenção de vias e pontes, o núcleo edificado de São Paulo auxiliava a constituição da "ordem". (PEREIRA, 1988) Isso favoreceu o desenvolvimento da mão de obra voltada para a construção, fazendo com que se estabelecessem na cidade alguns mestres de obra, pedreiros, carpinteiros, entre outras profissões relacionadas à construção.

A Câmara procurava estabelecer critérios para a construção de moradias e formação de arruamentos, assim como para a incorporação das terras de uso comum. $O$ rocio continuava a ter importância para os moradores e especialmente para a Câmara pois neles era possível, por exemplo, promover a engorda do gado, atividade passível de fiscalização e taxação, representando uma importante fonte de renda para a organização municipal.

O aumento da população registrado nos censos que seriam realizados a partir de 1765, aliado ao incremento na divisão do trabalho, representou alguma mudança na fisionomia das construções da vila. Apesar disso, ainda que fosse possível se encontrar tijolos em algumas olarias na vila, a técnica construtiva que predominava - e que continuaria predominando em São Paulo - era a taipa de pilão, havendo apenas algumas construções em tijolo ou pedra. Geralmente os edifícios construídos com esses materiais mais duráveis eram os "mais sumptuosos e melhores" da cidade: os edifícios religiosos.

O desenvolvimento de atividades relacionadas à construção e ao avanço das técnicas construtivas, que passava da taipa ao tijolo, ainda que muito lentamente, incluía cada vez mais os rios de São Paulo, sobretudo o Tamanduateí, devido à extração de areias, cascalhos e argilas das margens e várzeas. A taipa de pilão, que era feita basicamente com recursos da terra, dava espaço a técnicas construtivas que exploravam mais as condições do rio.

57. São Paulo foi elevada à condição de cidade em 1711. 
Em 1775, o núcleo urbano de São Paulo abrigava 1.722 habitantes, que ocupavam $460 \operatorname{casas}^{58}$. Apesar de esses números não considerarem os escravos, que não eram recenseados, eles apontam para um crescimento considerável no número de habitantes da cidade.

A maior preocupação continuava sendo a sobrevivência da vila, que resistia com os recursos que tinha. Esses recursos se dividiam entre produtos importados, de acesso limitado devido aos altos preços de transporte; produtos manufaturados na própria vila ou em localidades próximas; e recursos naturais, os "bens da terra", originários, também, das terras de domínio comum, incluindo os rios.

A cidade continuava a ser abastecida pelas águas dos rios e córregos próximos, além das fontes de dentro da vila, enquanto os dejetos eram despejados diretamente nesses mesmos rios e córregos. No que diz respeito ao abastecimento de água, a situação da vila parece não ter se alterado até meados do século XVIII quando foram instalados os primeiros dutos de derivação de água para abastecimento de São Paulo, sendo que o primitivo sistema de abastecimento de água em fontes, que já vinha sendo usado por cerca de 200 anos, continuaria fornecendo água para a vila.

Foi nesse contexto, ou seja, a partir da maior diversificação das atividades urbanas, impulsionadas pela atividade da construção e consequente maior disponibilidade de mão de obra como artesãos e construtores, e do aumento populacional, que foi instalado em São Paulo o seu primeiro sistema de distribuição de água ${ }^{59}$.

Esses primeiros condutos ainda não eram suficientes para servir todos os moradores da cidade. Ao contrário, grande parte da população

58. PORTA, Paula. História da Cidade de São Paulo, vol.ı: A cidade Colonial. São Paulo: Paz e Terra, 2004.

59. Para Marx, segundo Jorge Oseki, no modo de produção asiático, a união pelo Estado das comunidades camponesas, se dá através da rede hidráulica. "O Estado se encarrega dos problemas colocados pelo domínio sobre a água: diques, drenagens, irrigações [...] Esta execução de uma rede hidráulica é acompanhada construção de estradas, colocando em relação as unidades produtivas, estradas de uso civil, militar e religioso". Ainda segundo Oseki, em países asiáticos, como Índia e China, e nessa região, a água tem maior importância que a terra, onde a renda é extraída da água e do uso da água, mais do que do solo. LEFEBVRE, Henri. De l'Etat, tomo II, 10/18 - Union Génerale d'Éditions, 1976, p.226-227 apud OSEKI, 1992, p.114. 
ainda se abastecia nos rios ou em fontes naturais, onde foram edificadas bicas e chafarizes, ou em córregos e nos rios Tamanduateí e Anhangabaú. Em qualquer desses casos, a água já parecia impura, uma vez que os despejos de águas servidas continuavam a acontecer nos mesmos rios que abasteciam a cidade. Esse fato não impediu que diversas fontes fossem abastecidas com água do Tamanduateí e outros córregos cujas águas eram consideradas impróprias.

A respeito de quando teria se iniciado o processo de poluição do rio Tamanduateí, é muito difícil determinar uma data, já que a preocupação com esse rio só passou a ser manifestada quando a sujeira apareceu visualmente ou através do seu cheiro. $O$ fato é que desde muito cedo esse rio recebeu despejos. O seu leito favorecia a estagnação das águas formando brejos e atoleiros. Sua inclinação é mínima e o solo é sedimentar e argiloso, dificultando a drenagem, principalmente nos messes de cheia. Segundo Maria Vicentina do Amaral Dick ${ }^{60}$, o nome Tamanduateí na língua tupi significa rio dos tamanduás verdadeiros, aparentemente, devido à presença desse animal nas margens desse rio, interessados nas formigas que se acumulavam sobre peixes que eram ali deixados apodrecendo após os períodos de cheia. Pode-se supor que esses peixes podres já representassem alguma poluição mesmo antes da presença do colonizador, ainda que não existam registros nesse sentido. Entretanto, como se verá mais adiante, era costume indígena a prática da pesca com venenos muito fortes, mostrando que a depredação da natureza não era uma característica somente do colonizador.

A estrutura do primeiro sistema de distribuição de água de São Paulo era precária: uma rede de valas abertas diretamente na terra, por onde a água corria pelas ruas a céu aberto, estando muito suscetível a contaminações, desvios e apropriações indevidas. Era comum que algum proprietário de terra, motivado pela grande comodidade que a água trazia, se apropriasse da água, fazendo para isso desvios no curso para dentro de sua propriedade.

A precariedade do sistema e essas apropriações faziam com que a água frequentemente não chegasse até as fontes e chafarizes da cidade, causando enorme transtorno já que a maior parte da população se abastecia dessas águas. Evidentemente, isso não acontecia sem conflitos e protestos pois, ainda que não existisse uma regra clara que garantisse

6o. DICK, Maria Vicentina de Paula do Amaral, A Dinâmica dos Nomes na Cidade de São Paulo 1554 - 1897 . São Paulo, Annablume, 1996. 
o livre acesso a esse recurso, sabia-se, como vimos no capítulo anterior, que não se podia negar acesso às águas e terras de uso comum.
“[...] para que a água chegasse aos chafarizes, era preciso per- correr um trajeto diversificado a céu aberto: em geral, a água corria por meio de regos; esses, por sua vez, atravessavam be- cos, ruas e, às vezes, quintais de alguns moradores. Nada ga- rantia, portanto, que a água chegasse aos chafarizes sem ter sido, pelo caminho, utilizada por várias pessoas e desviada por famílias poderosas." ${ }^{61}$

Ainda que existisse uma forma oficial de se apropriar da terra, a apropriação da água permanecia sendo feita como um reflexo das apropriações de terra. A indefinição das regras de apropriação da água dava espaço para diferentes interpretações e concepções sobre o seu uso.

A situação das bicas e chafarizes onde se consumia e coletava água também não era a ideal. Ernani Silva Bruno, sobre uma bica que existia no ribeirão Acu, relata que mesmo com algumas melhorias,
“[...] ela continuou [...] recebendo ciscos e estercos, através da umidade dos quintais de alguns moradores de suas vizinhan- ças. Cheiravam mal as suas águas e tinham sabor horrendo, di- zia uma ata da Câmara. Não eram melhores porém as águas do Tamanduateí e do Anhangabaú, em que se servia "a maior parte dos povos" escrevia-se no ano de 1787." (BRUNO, 1991, p.284)

Essa rede abasteceu, em 1744, o convento do largo de São Francisco que passou a contar com fornecimento de água potável canalizada captada no rio Anhangabaú. ${ }^{62}$ Nos anos seguintes os conventos de Santa Teresa e da Luz também contariam com esse fornecimento a partir de canalizações dos rios Anhangabaú e Saracura respectivamente.

Uma breve comparação entre o fornecimento de água das cidades do Rio de Janeiro e São Paulo nesse período é reveladora. No Rio, as ten-

\footnotetext{
61. SANT'ANNA, Denise Bernuzzi. Cidade das Águas: usos de rios, córregos, bicas e chafarizes em São Paulo (1822-1901). São Paulo: Editora Senac, 2007, p.91.

62. FREITAS, Afonso A. de. Dicionário Histórico, Topográfico, Etnográfico, Ilustrado do Município de São Paulo, I, p.72 apud BRUNO, Ernani Silva. História e Tradições da cidade de São Paulo: vol.1 Arraial de Sertanistas (1554-1828). São Paulo: Hucitec, 1991, p.282.
} 
tativas governamentais de solucionar o problema do abastecimento de água datam de $1561^{63}$. Em 1673, foi iniciada a obra do primeiro aqueduto do país, que, inaugurado em 1723, transportava as águas do rio Carioca em direção ao centro da cidade, onde eram distribuídas em chafarizes. Atualmente conhecido como "arcos da Lapa", o aqueduto da Carioca é uma estrutura de cerca de 270 metros de comprimento e 17 metros de altura, construída em pedra assentada com argamassa. Para a construção do aqueduto foi utilizada a mão de obra escrava, indígena e negra africana, já sob a coordenação da engenharia carioca. Essa diferença nas redes de abastecimento, dos materiais aplicados e dos profissionais envolvidos, no mesmo período da história das duas cidades, reflete a sua inserção no contexto da produção colonial e o desenvolvimento desigual pelo qual passava a colônia.

Sobre a mão de obra e os materiais utilizados na primeira rede em São Paulo, pouco foi registrado. Entretanto, sabe-se que sua principal característica era a precariedade e vulnerabilidade a contaminações, o que nos faz pensar que os materiais aplicados não eram os mais apropriados. Os documentos existentes não registraram a mão de obra utilizada na execução das valas da rede. Como vimos, escravos negros não entravam nem mesmo nos censos realizados no período, e o trabalho indígena, proibido desde o século XVI, continuava sendo omitido dos registros oficiais. Entretanto, é possível supor que essas obras tenham sido realizadas por essas duas modalidades de trabalho.

Sabe-se ainda que, para a construção das fontes de pedra do largo São Francisco, foi contratado um mestre pedreiro chamado Cipriano Funtan, sendo executadas em pedra de cantaria e canos de bronze, contando com duas bicas e duas pias ${ }^{64}$.

Apesar de ainda poucos, alguns mestres construtores se faziam presentes em São Paulo, entre brancos, escravos negros e negros forros, o que representava certa diversidade na disponibilidade de trabalhadores, ainda que as Atas da Câmara registrem com frequência a falta de mão de obra qualificada para construção (PEREIRA, 1988). A notação que segue, de Carlos Gutierrez Cerqueira, confirma essa informação. Segundo esse autor, na cidade de São Paulo em 1765, havia

\footnotetext{
63. O primeiro indício de saneamento no Brasil é de 1561, quando Estácio de Sá realizou a escavação de um poço para abastecer a cidade do Rio de Janeiro.

64. CERQUEIRA, Carlos Gutierrez. Tebas - Vida e Atuação na São Paulo Colonial. IPHAN/SP, 2011.
} 
“[...] apenas três Pedreiros: Antonio do Rozario (preto forro, casado, 45 anos de idade, com renda de 100 mil réis anuais); Estevão da Silva (branco, casado, 54 anos, renda não mencionada) e o Bento de Oliveira Lima (branco, casado, 56 anos e com renda de 500 mil réis). Esse Bento era Senhor de quatro escravos Oficiais de Pedreiro e, entre eles, o pardo Tebas. (CERQUEIRA, 2011)

Isto evidencia o contexto das atividades de construção desse período. Além da atividade individual independente de um branco e um negro forro, existe nesse momento um proprietário de escravos, uma espécie de empreiteiro, que mantinha uma equipe de oficiais de pedreiro composta por escravos negros.

A obra do chafariz do largo da Misericórdia, uma das mais utilizadas e duradouras fontes da cidade, foi construída em 1792, graças a contribuições da população e doações de algumas famílias ${ }^{65}$. Realizado com "pedras da região de Santo Amaro transportadas em canôas e desembarcadas no pôrto da Tabatingüera" (BRUNO, 1991, p.285), possuía quatro torneiras de bronze e era abastecido com as águas do Anhangabaú, captadas nas proximidades do antigo Tanque Municipal.

Esse chafariz foi construído por Joaquim Pinto de Oliveira, conhecido como Tebas. Escravo nascido em Santos, esse construtor se tornou notório pela qualidade do seu trabalho e pela frequência com que foi contratado em obras importantes da cidade. A maior parte das obras realizadas por Tebas aconteceram quando ele ainda era escravo, propriedade de Bento de Oliveira Lima ${ }^{66}$. Mesmo depois do falecimento do seu

65. Segundo Ernani Silva Bruno, "a sua construção parece ter exigido esforço enorme das autoridades, pois desde 1784 recebia a Câmara recursos para sua edificação e esbarrava com dificuldades inclusive para a escolha das águas com que devia ser abastecido". (BRUNO, 1991, p.285)

66. Segundo Carlos Gutierrez Cerqueira, Bento de Oliveira Lima "desfrutava de uma condição bastante razoável para os padrões vigentes à época em S. Paulo. Seu patrimônio consistia em uma pequena casa, de lanço e meio de taipa de pilão, localizada no largo do Colégio; num sítio no bairro do Caaguaçú, onde tinha 40 cabeças de gado e algumas plantações, e outros bens que totalizavam, juntamente com os dez escravos que possuía, 1:572 $\$ 880$ réis. Dentre os escravos, um era Oficial de Sapateiro e outros quatro Oficiais de Pedreiro, figurando aí o mulato Joaquim, com idade de 36 anos pouco mais ou menos que foi avaliado em 400 mil réis - quantia aliás muito superior aos demais Oficiais Pedreiros, por quanto os outros três, juntos alcançavam apenas 319 mil réis. $O$ valor indicado pelos avaliadores ao escravo Joaquim, no inventário que então 
proprietário, continuou trabalhando como propriedade da viúva, dona Antônia Maria Pinta, sendo responsável por parte significativa dos rendimentos desta última. Tebas gozava de certa autonomia, podendo ele mesmo assinar os contratos das obras e construções, mesmo estando sob a condição de cativo. Ao passar a ser propriedade do cônego Matheus Lourenço de Carvalho, obteve a sua alforria, por volta do final da década de 1770 , mediante a conclusão da obra do frontispício da Igreja da Sé, passando, depois disso, a empreender obras de maneira independente. Esse foi o caso da obra do chafariz da Misericórdia, construída no largo em frente à igreja de mesmo nome $e^{67}$.

Segundo Affonso A. de Freitas, Tebas também foi o responsável pela reconstrução da antiga catedral de São Paulo em meados do século XVIII e também da torre do convento de Santa Teresa. (FREITAS, 1985) Ainda segundo Freitas,

"Fez-se ainda Tebas engenheiro hidráulico assumindo e realizando o encargo de estabelecer o primeiro abastecimento público regular de água à Paulicéia, com a construção, em pedra de cantaria, do antigo chafariz do largo da Misericórdia e derivação canalizada para este, das águas do Anhangabaú." (FREITAS, 1985, p.63)

Ainda que não seja possível determinar qual foi a mão de obra utilizada para a realização dos condutos de água dessa primeira rede de São Paulo, é possível observar que o trabalho que envolve as atividades relacionadas à água ganham certa diversidade em meados do século XVIII. Essa diversificação representa certo desenvolvimento na divisão do trabalho, o que é confirmado pela existência simultânea do trabalho cativo, in-

se fez dá a medida da importância que teria Tebas na execução dos trabalhos contratados por Mestre Bento de Oliveira Lima. Dispunha este, portanto, de capital e mão-de-obra qualificada suficientes para empresariar qualquer obra de construção na cidade, assim como de algumas propriedades que podia recorrer para "afiançar" as obras que arrematava". (CERQUEIRA, 2011)

67. Conforme explica Denise Bernuzzi de Sant'Anna, esse local era "bastante procurado pelas vendedoras de quitutes, habituadas a se acomodar a se acomodar junto a seus tabuleiros sobre a escadaria de pedra de cantaria da igreja. Vendiam cuzcuz de bagre e de camarão de água doce, biscoitos de polvilho, bolos de milho socado ou de mandioca puva, pinhão quente, amendoim torrado, empadas de piquira ou lambari, pé-de-moleque, entre outros salgados e doces. O local do chafariz era procurado por vendedores de todo tipo, além de pedintes e diversos curiosos". (SANT'ANNA, 2007, p.97) 
dígena e negro, e pelo trabalho livre. A existência dessas categorias de trabalho, de um empreiteiro que liderava uma equipe de escravos, e a própria atividade de Tebas, de trabalhador cativo a homem livre, revela a complexidade das transformações que aconteciam em São Paulo.

Assim como foi visto, dentro da economia colonial, o preço do escravo era definido pelo retorno futuro do investimento de capital que se fazia na compra. Esse investimento significava um custo fixo para o proprietário independentemente se o escravo estivesse trabalhando ou não. A busca pela redução dos custos de manutenção do escravo fazia com que o trabalho cativo fosse aplicado nos intervalos das atividades produtivas ligadas à atividade colonial de exportação. Ainda que esse rendimento, acumulado à margem do mercado agroexportador, significasse algum aumento da riqueza do proprietário, ele não se constituía como um fluxo de renda monetária. (PEREIRA, 1988)

No caso citado de Bento Oliveira de Lima e sua equipe de oficiais cativos, a sua atividade já aparece aqui como um avanço na divisão do trabalho aplicado à atividade da construção. As descrições acima nos permitem afirmar que os trabalhos de construção realizados pelos escravos de Bento eram a sua principal atividade, não estando atrelada à qualquer produção voltada ao mercado externo à cidade. O preço do escravo, pago por Bento para adquiri-lo, continuava a ser definido pelo retorno futuro do investimento de capital realizado na sua compra. Entretanto, os rendimentos obtidos na realização das empreitadas, agenciadas pelo proprietário, já se configuravam como um fluxo de renda monetária. Isto é, o proprietário, assim como no caso da produção agroexportadora, aparece como a pessoa que se apropria em primeira mão do trabalho excedente dos produtos diretos.

\section{LUTAS PELO CONTROLE E POSSE INDIVIDUAL DA ÁGUA}

O comportamento da Câmara Municipal com relação às terras municipais oscilava, ora defendendo os moradores e os espaços de domínio, ora parecendo mais preocupada em defender questões particulares. A organização municipal ocupava-se mais com a defesa da vila e a fiscalização do transporte de produtos do que com a regulamentação da distribuição de terras.

Alguns casos relatados nas Atas da Câmara esboçam tentativas de 
patrimonialização da água, paralelamente ao processo de patrimonialização das terras de uso comum. Esses registros revelam casos em que proprietários de terra onde se localizavam nascentes, fontes ou por onde passava um curso d'água, tentavam se apossar da água e impedir o seu uso cercando, impedindo o acesso, desviando o seu curso ou usando de violência.

Era comum em São Paulo, no período colonial, que proprietários de terras cercassem suas propriedades como forma de evitar o acesso de outras pessoas a rios, tanques e bicas (SANT'ANNA, 2007). Assim como foi dito, não havia regra que normatizasse o uso da água, tornando-se comum que diversos conflitos envolvendo a água da cidade fossem registrados nas Atas da Câmara da Vila. Isso acontecia apesar de haver uma noção de que a água era um importante recurso e que não se podia coibir ou impedir o seu uso. Essa apropriação se dava como uma decorrência quase intuitiva das regras sobre uso e posse da terra, que eram mais claras, o que nem sempre resultava em concordância, já que a água, fisicamente, se comporta de uma forma muito diferente da terra.

Como não havia uma determinação de como a água deveria ser tratada e regulada, a posse da terra dava a entender para o proprietário que a água que passa por suas terras também era sua propriedade, sendo que os não-proprietários viam essa mesma situação de uma forma distinta.

Cabe ressaltar que, inicialmente, as primeiras canalizações aconteceram sem qualquer planejamento, mas, aos poucos, essas atividades começaram a contar com a presença de técnicos e engenheiros.

Os casos citados a seguir são exemplares pois caracterizam o papel da água nesse momento em São Paulo. A água aparece como um objeto de interesse ainda ambíguo, variando entre a condição de bem comum e de um possível gerador de renda. Esses casos também revelam a posição oscilante da Câmara, que se organizava a partir de novas relações políticas e econômicas. As indefinições sobre o uso da água pareciam pairar inclusive sobre a municipalidade que, preocupada com questões de outra ordem, deixava essas questões indefinidas, entre a defesa de interesses comuns e particulares.

Apenas algumas famílias e instituições possuíam fontes dentro de suas propriedades para consumo privado, o que representava um conforto considerável para o período. Esse era o caso dos frades do Largo São 
Francisco que possuíam, desde 1744, uma fonte dentro do claustro ${ }^{68}$.

Devido a esse sistema, os franciscanos dispunham de um fornecimento de água abundante, e por esse motivo pretendiam encaminhar as sobras dessa água para uso público. Para isso, foi projetado um sistema com duas saídas de água, uma "dentro da cerca" do convento, destinada ao uso exclusivo dessa comunidade, e outra que despejava para fora as sobras dessa água para uso do restante dos moradores ${ }^{69}$.

A Câmara pressionava os frades para que destinassem parte dessa água, que abundava, para a população (GASPAR, 1970). Pela ausência de legislação que regulasse o uso da água na vila, pode-se entender que trata-se aqui de um caso de apropriação privada desse bem comum, mas que, devido à importância política dessa instituição, esse fato se transformava em um ato de caridade.

A obra foi orçada em $400 \$ 000$. Os franciscanos solicitaram auxílio de $300 \$ 000$ à Câmara que, posteriormente, se comprometeu a colaborar cedendo a exploração do açougue municipal aos frades até que esses levantassem a quantia necessária à realização do sistema. As obras, que demoraram a se iniciar ${ }^{70}$, foram concluídas e os dois chafarizes foram postos em funcionamento. As águas que sobravam do chafariz "de fora" constituíram o primeiro chafariz para abastecimento público de São Paulo. Entretanto, esse chafariz teve curta duração, sendo desmantelado logo no início do século XIX, após diversas paralisações para reparos. (GASPAR, 1970 e BRUNO, 1991)

68. Segundo Denise Bernuzzi de Sant'Anna essa fonte de pedra foi construída pelo mestre de obras chamado Cipriano Funtan (SANT'ANNA, 2007, p.98).

69. GASPAR, Byron. Fontes e Chafarizes de São Paulo. São Paulo: Conselho Estadual de Cultura, 1970, p.21.

70. Segundo Byron Gaspar a Câmara utilizou um artifício gentil para fazer uma "suave advertência" aos frades: a Câmara contratou o mesmo mestre que construiria a obra original, Cipriano Funtan, para a construção "na paragem chamada Inhangavahu, aterrado o sítio em capacidade de ficar vistosa a fonte, que terá doze palmos em quadra de chão lajeado, duas pias boas, de pedra, e mais capaz com frontispício de doze palmos em quadra, com sua cimalha bem feita, com pirâmide e cruz, tudo de cantaria, de boa pedra, e tôda a obra à satisfação" (Revista do Arquivo Municipal de São Paulo, Ano II, XIV, 165 apud GASPAR, 1970, p.22) "Essa obra, porém, não foi feita "por falta de água", conforme se vê de uma nota de 2 de dezembro do mesmo ano. Entretanto - informa Afonso A. de Freitas -, água havia, não só a que poderia ser captada no alto Anhangabaú, como a do Mandiocal, cabeceira do Saracura, ambas aduzíveis por gravidade para o projetado chafariz" (GASPAR, 1970, p.21-22). Aparentemente, esse artifício funcionou já que os frades iniciaram as obras logo depois. 
Em 1829 as Atas da Câmara registravam um debate sobre uma solicitação para tornar o uso das águas do chafariz "de dentro da cerca" de uso público. Essa solicitação demorou muito a ser enviada, já que se sabia que os frades se opunham à remoção da cerca que delimitava a sua propriedade.

A fundação da Academia de Direito no próprio Largo São Francisco fez com que a população do centro da cidade tivesse um aumento considerável, já que "os estudantes chegavam acompanhados de suas famílias e escravos, como também pela fixação contínua de toda sorte de comerciantes" e a Câmara se via pressionada a tomar uma posição. (GASPAR, 1970, p.22-23)

O fornecimento de água para essa porção da vila continuou prejudicada até que uma resolução da Câmara pôs fim à questão tomando as

“[...] providências necessárias a prol do bem público, êste reclamando por maior número de fontes e espaço para o tráfico dos condutores e seus animais, mandando aproveitar todo terreno contíguo ao centro da cidade, e abrir ruas e edifícios e casas de morada para habitação dos povoadores e dos acadêmicos, e, achando-se nessas circunstâncias o terreno exterior ao edifício do Curso Jurídico, a Câmara fêz derrubar os muros da frente e pôs em servidão pública a água que dantes servia aos religiosos de São Francisco"71.

Após diversas paralisações para reformas, desmantelamentos e reconstruções, a água foi extinta no Largo São Francisco em 1876 com a demolição dos chafarizes. (GASPAR, 1970, p.25-26)

Um dos pequenos córregos, afluentes do Anhangabaú, de que se servia a população da vila era o Yacuba, ou $\mathrm{Acu}^{72}$, cuja cabeceira se formava no

71. Atas da Câmara Municipal, XXIV, p.450 apud GASPAR, 1970, p.23.

72. Segundo Byron Gaspar a denominação Yacuba vem do tupi-guarani onde Y seria água e acuba, venenosa. "Com o correr do tempo, o vocábulo Yacuba foi-se contraindo em Yacu, Guacu e Acu, para depois da segunda metade do século XVIII fixar-se definitivamente em Acu, estendendo-se pelos arredores até o início da atual Avenida São João e denominando, também, a ponte sobre o Anhangabaú, naquele ponto. Desaparecido o córrego, a palavra Acu restringiu-se à bica" (GASPAR, 1970, p. 27). Apesar da fama de envenenadas, as águas do Yacuba eram muito utilizadas pela população da vila (GASPAR, 1970, p.28). Segundo Affonso A. de Freitas, o Tanque do Zúniga era o local de uma das principais 
Tanque do Zúniga ${ }^{73}$ e em seu trajeto abastecia a bica do Acu antes de encontrar o Anhangabaú, próximo da rua Miguel Carlos, atual Florêncio de Abreu. Sabe-se que essas águas, apesar de não serem as mais limpas da vila, eram muito utilizadas pelos moradores da região para ingestão e para lavagem de roupas. (GASPAR, 1970, p.28)

O local onde se encontrava o tanque e abrigava as nascentes do Yacuba era propriedade do sargento Manuel Caetano Zúniga, que também possuía outras terras em São Paulo (SANT'ANNA, 2007). Affonso A. de Freitas calcula que esse tanque produzia cerca de 10 polegadas de água, que escoavam por um leito escavado no chão (FREITAS, 1985) e, portanto, pelas referências da época e segundo esse autor, não se tratava de um volume de água desprezível.

Em 1780, o sargento tentou impedir o acesso à água do ribeirão Yacuba, já que havia conseguido junto ao ouvidor da cidade que parte do córrego fosse desviado para o seu quintal, impedindo, portanto, que outras pessoas utilizassem a água. Sempre que uma pessoa era flagrada utilizando essa água era expulsa do local pelos escravos do sargento, que estavam autorizados, inclusive, a distribuir pancadas (SANT'ANNA, 2007, p.89). O sargento foi, diversas vezes, acusado de usar de violência para remover lavadeiras do local, como foi registrado no trecho que segue:

“[... ] sobre uma água que o sargento-mor Manuel Caetano Zúniga quer impedir que o povo e moradores do Acu se não sirvam dela [..] representamos a Vossa Excelência as violências que experimenta o povo do bairro da ponte do Anhangabaú [...] com o sargento-mor Manuel Caetano Zúniga a respeito deste lhe impedir lavar a pobreza roupas em um tanque de água que a maior parte do povo se serve dela para lavarem suas roupas e outros misteres pelo retiro em que está, e não haver outra naquela paragem, com o pretexto de lhe chamar sua por provisão [...] em virtude da qual fez entrar a correnteza da dita água em um quintal que este tem no dito bairro e por este poder não deve o dito sargento-mor tapar o

nascentes do riacho Iacuba, tributário do Anhangabaú, e que em seu trajeto alimentava a bica do Acu. (FREITAS, 1985, p.190).

73. Segundo Denise Bernuzzi de Sant'Anna a grafia desse nome variou com o tempo “Zúniga, Zunega, Zunicas, Zuniças e Zuniga.” Ainda segundo essa autora o local do tanque também era conhecido como praça das Alagoas devido a existência de diversos lagos na região. (SANT’ANNA, 2007) 
dito tanque, nem impedir ao povo que aí vá lavar como fez no dia quinze do presente mes, e em outros que achando-se duas mulheres brancas, casadas de boa nota, as descompôs de palavras injuriosas, è̀s pretas the tirou as roupas pelas matas querendo-lhes dar, e mandando pelos seus negros em outros dias correr com elas, e rebaixar por eles o dito tanque a fim de que não junte água para se lavar roupas nem poderem tomar suas casas [...]." (FREITAS, 1985, p.190-191)

Vemos por esse registro nas Atas da Câmara da Vila de São Paulo que o sargento também tentou impedir o acesso às águas do tanque rebaixando o nível desse reservatório além de desviar o curso do rio. Esse registro, além de deixar claro que não havia clareza sobre as regras do uso da água, revela que já nesse período os corpos d'água da cidade sofriam intervenções drásticas, como essa drenagem e desvio de curso mostram. No século XIX o tanque foi secado, a bica desfeita e o córrego tampado ${ }^{74}$.

No ano de 1814 o Governo Provisório da Província de São Paulo incumbiu o engenheiro militar Daniel Pedro Müller ${ }^{75}$ da construção da estrada do piques, que ligava São Paulo a Sorocaba, com a intenção de facilitar a integração com o interior da capitania. As obras consistiam: na formação do Largo da Memória; no alargamento e embelezamento das ladeiras do Piques e Sete de Abril; no levantamento de um paredão de arrimo na atual rua Xavier de Toledo; na edificação de um chafariz no ponto de

74. Em 1855 o Tanque do Zúniga foi secado e terraplanado, dando lugar ao atual Largo do Paissandu, em uma obra coordenada pelo engenheiro Carlos Rath atendendo a um pedido do presidente da província dr. Antônio Roberto de Almeida. As águas das nascentes que alimentavam o tanque foram então conduzidas por tubulações de ferro até o início da atual travessa do Paissandu onde foram instalados chafariz e lavadouro. (FREITAS, 1985, p.190) Finalmente, o córrego Yacuba foi canalizado pela Repartição de Águas e Esgotos em 1898, mesma época em que a bica do Acu desapareceu. (GASPAR, 1970, p.27)

75. Segundo Ernani Silva Bruno, "o Marechal Daniel Pedro Müller, filho de alemães que se fixaram em Portugal, nasceu no mar quando sua família viajava para Lisboa, e veio para o Brasil como ajudante-de-ordens do governador Franca e Horta (1802-1811). Era engenheiro militar, e além da pirâmide e do chafariz do Piques dirigiu a construção da antiga ponte do Carmo. (BRUNO, 1984, p.1444) Segundo Denise Bernuzzi de Sant'Anna, "autor de pontes e estradas importantes, Müller foi também o responsável pela construção da famosa Estrada da Maioridade (nome dado em homenagem à maioridade de D. Pedro II). A estrada ficou pronta em 1844, ligando São Paulo a Santos, em substituição à antiga calçada do Lorena". (SANT'ANNA, 2007, p.100) 
confluência das ladeiras; e, como complemento, na ereção de um obelisco à memória do "zêlo do bem público" demonstrado pelo governo. (GASPAR, 1970, p.39)

Os trabalhos foram concluídos em 1815. As águas do chafariz ${ }^{76}$, que eram as águas do Tanque Reúno ${ }^{77}$, foram interceptadas de um curso d'água que saía do tanque, se dirigia ao morro do Chá e que, passando pelo bairro de Santa Ifigênia, finalmente chegava ao Jardim Botânico para alimentar o lago central do atual Jardim da Luz. (GASPAR, 1970). Dada a extensão do curso, vários moradores se serviam dessa água, que foi objeto de disputa em diversas ocasiões, implicando a intervenção da organização municipal.

Por volta de 1822, já durante o Império, o brigadeiro Joaquim José Pinto de Moraes Leme foi acusado de monopolizar o curso d'água. $\mathrm{O}$ brigadeiro foi intimado pela Câmara a tapar um desvio do curso que cortava partes da vila formando um sulco profundo no chão e que poderia causar acidentes. Além disso, o desvio servia exclusivamente a propriedade do brigadeiro, o que gerou diversos conflitos com outros moradores e com um convento localizado nas proximidades: o recolhimento da Luz, que, teoricamente, teria o mesmo direito de usar a água.

O brigadeiro respondeu a intimação alegando que a adequação do canal deveria ser paga por todos que residiam nos locais por onde a água passava (SANT'ANNA, 2007). Ele acusava um vizinho, Joaquim Floriano de Godói, de também usufruir da água do desvio. Entretanto, mais tarde, alegou que as obras realizadas na construção da pirâmide do Piques, coordenadas pelo engenheiro Daniel Pedro Müller,

\section{“[...] perverteu a direção direta do rego de nossa servidão para introduzir a passagem da nossa água em um tanque, que, sen- do mal construído, logo se danificou pela causa de ter o dito engenheiro invertido o nível do rego antigo".$^{8}$}

\footnotetext{
76. O chafariz do Piques era um ponto de descanso para tropeiros e viajantes que chegavam à vila, portanto, um equipamento importante no cotidiano da cidade. Segundo Byron Gaspar, "o encanamento da bacia da pirâmide ao chafariz era descoberto, feito de telhões unidos com betume". (GASPAR, 1970, p.39 nota 1)

77. Segundo Denise Bernuzzi de Santana, o Tanque do Reúno "era formado pelo ribeirão Saracura, no cruzamento da atual avenida Nove de Julho com o viaduto Martinho Prado". (SANT'ANNA, 2007, p.93).

78. Departamento de Cultura, São Paulo, Registro geral, 18, 329, 7 de outubro de 1825 apud SANT'ANNA, Denise Bernuzzi de. Cidade das Águas: usos de rios, córregos, bicas e chafarizes em São Paulo (1822-1901). Editora Senac, São Pau-
} 
Após diversas trocas de ofícios, a Câmara decidiu que os custos da obra de regularização seriam cobertos pelo brigadeiro e pelo seu vizinho. (SANT'ANNA, 2007)

Em 1826, um outro caso envolveu o brigadeiro Joaquim José Pinto de Morais Leme. Ele foi acusado de obstruir um acesso ao rio Tamanduateí que se dava por um beco contíguo à sua propriedade.

Além desse acesso, havia ainda outras formas de acessar o rio Tamanduaté, através das ladeiras do Porto Geral na região de São Bento, do Carmo, próximo ao convento e do Fonseca na região da Tabatinguera. Por essas ladeiras era comum a presença de pessoas que transitavam em função da obtenção de água, como escravas equilibrando potes na cabeça. (BRUNO, 1991) A passagem próxima à propriedade do brigadeiro acontecia pelo beco do Colégio e era muito utilizada como conexão rápida entre a parte alta da cidade e o rio Tamanduateí. A passagem era especialmente muito utilizada por "lavadeiras, pescadores e carregadores de água" quando precisavam acessar as águas dos rio (SANT'ANNA, 2007, p.93).

$\mathrm{Na}$ ocasião, o brigadeiro construiu dois $\operatorname{muros}^{79}$ que impediam a passagem de pessoas, animais e carroças pelo beco e dificultavam o acesso ao rio. Após uma vistoria da Câmara e algum debate, o brigadeiro foi obrigado a remover os muros e liberar a passagem. (SANT'ANNA, 2007, p.93)

Em 1828 aconteceu uma disputa que envolvia as águas do Chafariz do Piques e do Tanque Reúno. Os atritos se deram entre o inspetor e diretor do Jardim Botânico, Antônio Maria Quartim, e o cônego Melchior Fernandes Nunes. Quartim acusou a Câmara de negligência ao desviar as águas destinadas ao lago do Jardim e usá-las no Chafariz do Piques onde, segundo a acusação, "não houve cuidado em betumar as costuras

\section{0, 2007.}

79. Segundo Denise Bernuzzi de Santana, "a moradia do brigadeiro era vizinha à residência do padre João José Vieira Ramalho quando, então, ele resolveu abocanhar um pedaço do beco, construindo um baldrame de pedra e outro de taipa, ambos pouco discretos: o primeiro media cerca de cinco palmos (1,10 metro). Segundo uma vistoria da Câmara, essas construções invadiam cerca de uma braça (2,20 metros) o quintal daquele padre e, como se não bastasse isso, elas impediam a passagem de animais, carroças e mesmo de pessoas pelo conhecido beco (SANT'ANNA, 2007, p.93). 
da cantaria da dta. pirâmide" ${ }^{80}$ acarretando perda de água e dificuldades em obtê-la nesse chafariz. Quartim também acusou de desvio o cônego que, segundo ele,

"[...] possui defronte o dito chafariz uma morada de casas, em cujo quintal quer por todos os meios e modos ter água permanente, seja ou não seja com deteriorações, ou diminuições das duas águas, da pirâmide e chafariz". ${ }^{81}$

A defesa do cônego alegava que a água que ele desviava era uma água suja que não serviria a ninguém:

"Acresce demais a mais ser caluniosa a imputação que faz o mesmo Inspetor ao cônego Melchior, cidadão benemérito, virtuoso e incapaz dos procedimentos de que é argüido: é constante no arquivo desta Câmara num termo assinado pelo mencionado cônego em que se obriga a calçar e verificar uma boa porção de calçada concedendo-lhe a Câmara desse tempo encanar para seu quintal a água já inunda". ${ }^{82}$

Segundo o cônego, o responsável pela falta d'água no piques era Quartim que teria desviado a água do Piques para o Jardim Botânico e não o contrário. Além disso o cônego alegava que

“[...] uma considerável porção de vizinhos daquele lugar, a maior parte gente pobre e que fica reduzida a precisão de ir demandar água muito longe, ao mesmo passo que esta insignificante parte de água que foi desviada para a dita fonte nenhuma falta pode fazer ao Jardim Botânico por ser sobra a que iria ter até lá." ${ }^{3}$

80. Arquivo do Estado de São Paulo, Obras Públicas, caixa 1, ordem 5.674, Jardim Público, Junta Comercial, Engenhos Centrais, Companhia Telefônica, 9 de janeiro de 1828 apud SANT'ANNA, 2007, p.94.

81. Arquivo do Estado de São Paulo, Obras Públicas, caixa 1, ordem 5.674, Jardim Público, Junta Comercial, Engenhos Centrais, Companhia Telefônica, 9 de janeiro de 1828 apud SANT'ANNA, 2007, p.94.

82. Arquivo do Estado de São Paulo, Obras Públicas, caixa 1, ordem 5.674, Jardim Público, Junta Comercial, Engenhos Centrais, Companhia Telefônica, 9 de janeiro de 1828 apud SANT'ANNA, 2007, p.95.

83. Arquivo do Estado de São Paulo, Obras Públicas, caixa 1, ordem 5.674, Jardim Público, Junta Comercial, Engenhos Centrais, Companhia Telefônica, 9 de ja- 
Em 1829, um ofício do vice-presidente da província deu razão a Quartim e ordenou que a Câmara restituísse a água do Piques ${ }^{84}$ ao Hospital Militar e ao Jardim Botânico. Os custos desse reparo foram arcados pela Câmara. Segundo Denise Bernuzzi de Sant'anna a Câmara acabou arcando com os custos de diversas obras de reparo e correção de cursos, principalmente quando as disputas envolviam figuras influentes da vila. (SANT'ANNA, 2007, p.96)

Ainda sobre o chafariz do Piques, sabe-se que essa obra foi executada pelo pedreiro Vicente Gomes Pereira, o "Mestre Vicentinho", e contava com condutos de telhas de barro betumado. Segundo Ernani Silva Bruno esse chafariz fora construído "com as sobras do material com que Daniel Pedro Müller realizara as obras de canalização do tanque do Bexiga". (BRUNO, 1991, p.288)

Dessa forma, percebe-se que a rede de condutos construída para abastecer o chafariz, continuava a aparentar certa precariedade, já que as "telhas betumadas", já nesse período, eram consideradas impróprias para esse fim pois permitiam que parte da água fosse perdida no curso e também por correr a céu aberto. O fato de essa obra ter sido construída com sobras de material de outra obra não parece aqui ser um sinal de precariedade, mas sim de economia de recursos.

As obras de maior importância em São Paulo, como pontes e estradas, já costumavam contar com a participação de engenheiros ${ }^{85}$. Entretanto era raro a participação desses profissionais nas obras relacionadas à provisão de água. Normalmente, nesse período, os engenheiros

neiro de 1828 apud SANT'ANNA, 2007, p.95.

84. Sobre o chafariz do Piques, sabe-se que passou por duas grandes reformulações em seu encanamento e estrutura entre os anos de 1867 e 1873 . A última notícia que se tem data é de 1876, provável data de sua demolição. (GASPAR, 1970, p.41) Segundo Afonso de Taunay, "a singela pirâmide do Piques, ainda hoje existente, levantada por ordem do capitão-general sob a direção e plano do tenentecoronel de engenheiros Daniel Pedro Müller rústico e moderníssimo padrão destinado a embelezar o local onde se construíra um chafariz". (TAUNAY, 2007, p. 172)

85. Sobre Cláudio Arasawa, "para as necessidades internas da maioria dos centros urbanos paulistas, até meados do oitocentos, bastava a existência de alguns mestres-de-obras ou mesmo de taipeiros, comuns ainda na entrada do novecentos. [...] A eles [aos engenheiros] opunham-se naturalmente os praticantes de ofícios manuais, dentre os quais os carpinteiros, mestres-de-obras, taipeiros, pedreiros e serralheiros que pareciam responsabilizar-se pela maioria das demandas referentes às atividades construtivas."(ARASAWA, 2008, p.39) 
existentes ocupavam cargos políticos nos governos provinciais e eram poucos os que se dedicavam a trabalhos nas cidades. Lentamente, esses trabalhos passaram a fazer parte desse campo do conhecimento, principalmente em atividades relacionadas a obras de provisão de infraestruturas urbanas e melhoramentos, tais como drenagem, esgotamento e abastecimento de água.

A maior participação de técnicos e profissionais da engenharia nessas obras pode ser explicada pelas transformações de ordem política e econômica por que passava a colônia no final do século XVIII. Com a restauração da capitania, sob a administração pombalina, as questões urbanas passaram a representar uma forma de afirmação do poder português, fazendo que se investisse mais no desenvolvimento material da cidade (ARASAWA, 2008). O caráter simbólico da cidade e da monumentalidade das edificações passava a ser mais valorizado. Isso acontece paralelamente ao declínio da mineração e ao aumento, em São Paulo, do desenvolvimento da produção rural e da maior presença do negro africano na produção. Na cidade de São Paulo isso significou o incremento da aplicação de recursos em melhorias materiais e maior investimento em caminhos de ligação por terra com o interior e com o litoral.

Ainda que nesse momento a participação desses profissionais seja muito pequena, é importante notar que a sua presença em projetos e obras na província e, especialmente, na cidade de São Paulo, passaria a ser frequente. Os problemas relacionados aos rios e às águas, como contaminações e surtos de doenças, passariam a integrar o campo dos conhecimentos técnico-científicos que, a partir desse momento seria muito valorizado. Esse fato é importante pois marca o momento em que, baseados na confiança nesses saberes e em uma imagem de modernidade, o Estado e a sociedade vão passar a reconhecer como verdadeiros os enunciados proferidos pelos profissionais da ciência, ainda que, em muitos casos, estivessem vinculados aos interesses dos grupos dominantes. A participação da ciência nos temas que envolvem os rios e as águas de São Paulo, no decorrer do século XIX, passaria a ser uma obrigatoriedade, não somente para resolver tecnicamente os problemas, mas também para legitimar as ações do Estado e empresas, cada vez mais envolvidos com a reprodução do capital comercial e industrial.

A presença desses técnicos na cidade também é uma evidência da necessidade crescente de controle sobre o espaço urbano que se intensifica com a transferência da côrte portuguesa para o Rio de Janeiro em 
1808. Essas atividades, inicialmente, tem um caráter regulatório personificado na figura do engenheiro militar e dos engenheiros fiscais, responsáveis por vistoriar e acompanhar obras públicas e particulares e por zelar pelo erário público. (ARASAWA, 2008)

Mesmo com a presença de alguns engenheiros e o avanço na diversificação das atividades comerciais urbanas observadas nesse período, a precariedade da distribuição de água de São Paulo persistia. O abastecimento de água, apesar dos avanços, permanecia insatisfatório em quantidade e qualidade. $\mathrm{O}$ esgotamento permanecia praticamente sem qualquer modificação desde o século XVI.

Isso acontecia, basicamente, pelo fato de São Paulo permanecer isolada da grande economia colonial.

No contexto de isolamento de São Paulo dentro da economia colonial, apesar dos avanços na divisão do trabalho e na diversificação de atividades, a materialização das condições gerais de produção não se viabilizava, isto é, a produção do espaço urbano como um produto coletivo necessário à socialização de produção de mercadorias e à apropriação do valor não acontecia. Isso porque, não somente a terra, mas tudo o que a constitui, ainda não aparecem como mercadoria. Dessa forma, assim como o espaço não se constitui em um produto, a divisão técnica e social do trabalho, pouco desenvolvida, inviabilizava a socialização da produção e consumo de mercadorias, o que refletia na provisão das infraestruturas. As infraestruturas eram, de maneira geral, consideradas apenas elementos estruturantes do espaço, não havendo, portanto, qualquer sentido nesses elementos que possam identificá-los como agentes de valorização das propriedades territoriais. A economia da cidade permanecia, portanto, visando apenas a produção para subsistência e manutenção da ocupação. 


CAPÍTULO 3 - SUBSISTÊNCIA PELO RIO: PESCA, AGUADEIROS, LAVADEIRAS E A RENDA DA ÁGUA

Paralelamente ao leve incremento na divisão do trabalho, à maior diversidade de atividades urbanas e ao pequeno aumento populacional, a rede de distribuição de água lentamente se ampliava. A instalação do primeiro sistema de abastecimento, além de precário e insuficiente, não implicou qualquer mudança na forma como os despejos eram realizados. Isso, inclusive, continuava acontecendo diretamente nas águas dos rios da cidade, principalmente às margens do Tamanduateí e do Anhangabaú. Essa atividade era executada por moradores, escravos negros e indígenas.

Além da ingestão, a contaminação das águas passava a dificultar e impedir outros usos dos rios.

A alimentação do morador de São Paulo certamente foi mais variada que a da população de outras cidades do Brasil no período colonial. A predominância da monocultura baseada na produção do açúcar afetava a produção de outros gêneros nos centros produtores, o que limitava muito a diversificação de gêneros alimentícios. Mesmo assim,

“[... apesar da fertilidade dos campos de Piratininga - com clima e terras que podiam condicionar o crescimento das lavouras e dos rebanhos de criação, como notaram alguns Jesuítas na era quinhentista - e a despeito dos esforços do poder municipal, 
de então por diante, revelados a todo momento através de uma porção de medidas que ficaram registradas nas Atas da Câmara, o abastecimento de carne, por exemplo, já no seiscentismo, se mostrou em geral bastante irregular, não só do ponto de vista da quantidade como da qualidade da mercadoria fornecida à população da vila." ${ }^{\prime 8}$

Dessa forma, a baixa diversificação de atividades e comércio, que resultava em um mercado atrofiado, tinha consequências em todos os aspectos da vida cotidiana dos moradores da vila. Mesmo assim, apesar da pobreza e da escassez de gêneros, era possível encontrar em São Paulo uma boa alimentação. Segundo Pe. Manuel da Fonseca, fazia-se um prato utilizando a canjica:

“[...] um guizado especial de São Paulo e mui próprio de penitentes", acrescentando: "consta de milho grosso de tal sorte quebrado em um plilão que tirando-lhe a casca e o ôlho fique o mais quase inteiro. É manjar tão puro e simples que, além da água, em que se coze, nem sal se lhe mistura. Finalmente, é sustento próprio de pobres, pois só a pobreza dos índios e a falta de sal por aquelas partes podiam ser os inventores de tão saboroso manjar." ${ }^{87}$

A pobreza de recursos e a falta de sal fizeram com que a canjica e o angu se tornassem a "base da alimentação nos primeiros tempos" aliados à caça e à pesca (BRUNO, 1991).

"Importância considerável na alimentação do morador de São Paulo durante os primeiros séculos devem ter tido os produtos da caça e da pesca. Nos tempos primitivos, principalmente os da pesca. Nos rios que corriam pela povoação e suas vizinhanças pescou-se desde os primeiros tempos [...]." ${ }^{\prime 8}$

86. BRUNO, Ernani Silva. História e Tradições da cidade de São Paulo: vol.ı Arraial de Sertanistas (1554-1828). São Paulo: Hucitec, 1991, p.253-254.

87. FONSECA, Manuel da. Vida do Venerável Padre Belchior de Pontes. p.55 apud BRUNO, 1991, p.259.

88. Essa notação de Silva Bruno (1991, p.197) indica que a pesca foi uma das principais fontes de subsistência dos moradores de São Paulo nos seus primeiros séculos. É importante notar também que junto à pesca, esse autor coloca a caça, como fonte de sustento. Cabe ressaltar que a prática da caça acontecia também 
A pesca, entretanto, sempre esteve, de certa forma, ameaçada devido ao costume indígena, que foi incorporado pelo colonizador, de utilizar venenos para matar os peixes. $O$ uso de materiais peçonhentos nas pescarias vinha de costumes antigos e de tradições indígenas. Essas práticas permaneceram ao longo dos anos, embora tivesse vindo dos portugueses o hábito de utilizar o anzol metálico. (SANT'ANNA, 2007)Essa prática ancestral utilizava o tingui ou timbó, um veneno" tão forte que nos rios onde se botava não ficava peixe vivo. As águas chegavam a ficar escuras. Doze mil peixes de uma vez contou Anchieta que viu matar assim." (BRUNO, 1991, p.258)

A Câmara se esforçava para preservar o sentido comum dos rios e garantir o uso das águas. Em 1591, a Câmara estabelecia que no Tamanduateí "ninguém mandasse nem desse tingui, com pena de quinhentos réis" 89 . É muito provável que essa técnica fosse mais aplicada no rio Tamanduateí já que as águas desse rio, sempre descritas como lentas e quase paradas, provavelmente permitiam que a coleta dos peixes mortos fosse mais efetiva que em outros rios.

Outra técnica primitiva muito utilizada para a pesca era conhecida por pari, cerca, tapume de taquara ou cipó, onde o rio era atravessado de margem a margem por uma cerca capturando os peixes que ali se prendiam. (BRUNO, 1991) Entretanto, essa técnica não parece ser menos ofensiva para o rio e sua manutenção, por comprometer a reprodução dos peixes. Nesse sentido, em 1626, registrava-se "que nenhuma pessoa use timbó nem ponha tresmalho em tempo que o peixe sai a desovar"90.

A preocupação com o período de desova dos peixes mostra que havia nítida consciência por parte da organização municipal, e certamente dos moradores, de que a contaminação das águas dos rios representava um problema para todos os moradores da vila de São Paulo.

A depredação dos rios também acontecia a partir da lavagem de roupas e de despejos realizados com frequência nos córregos, no Anhangabaú e Tamanduateí, causando doenças principalmente pela ingestão de água contaminada.

"Tudo parece indicar que a água e certos alimentos utilizados pelos moradores da cidade no setecentismo devam ter sido

em terras de domínio comum, ou seja, nas áreas que cercavam a vila, no rocio.

89. Atas da Câmara da Vila de São Paulo, I, p.425 apud BRUNO, 1991, p.258.

90. Atas da Câmara da Vila de São Paulo, III, p.231 apud BRUNO, 1991, p.258. 
pelo menos fatôres que concorreram para o aparecimento freqüente de enfermidades e sobretudo para sua propagação. [...] E as águas do Tamanduateí e do Anhangabaú, de que se servia a maior parte da população, [...] envolvia imundícies procedentes das lavagens de roupa e dos detritos que conduziam em suas inundações, com as quais "se podiam fazer pestíferas, em prejuízo da saúde dos povos"”91. (BRUNO, 1991, p.342)

Mesmo com os despejos e a ameaça do envenenamento das águas é importante assinalar que a pesca foi e continuou sendo por muito tempo ${ }^{92}$ fundamental para a subsistência dos moradores de São Paulo, "bem ou mal, havia peixe fresco de rio para o consumo da vila" (BRUNO, 1991, p.258). Segundo Afonso de Taunay,

“[...] nos livros da mordomia do mosteiro de São Bento [...] há referências preciosas a respeito, mostrando que os monges contavam freqüentemente com suprimento abundante de traíras, trairões, lambaris e outros peixes do Tietê e de seus tributários." ${ }^{93}$

Ainda segundo esse autor, "os rios das vizinhanças da cidade eram em meados do século dezoito mais volumosos do que hoje e podiam fornecer peixe com certa fartura" (TAUNAY, 2007, p.159).

As práticas da pesca nos rios de São Paulo permaneceram nos séculos XVIII e XIX, assim como as medidas tomadas pelo governo na tentativa de frear atividades predatórias. Em 1738, uma Ordem Régia

“[...] visando assegurar a abundância de peixe durante o ano todo, mandava que ninguém matasse peixe nas piracemas, nem botasse tinguijadas nem timbó e nem usasse de zanguizarras nem de rêdes de arrasto ${ }^{94}$. (BRUNO, 1991, p.271)

91. Atas da Câmara Municipal de São Paulo, XVIII, p.379-380 apud BRUNO, 1991, p.242.

92. Mesmo com as águas dos rios sujas, essa atividade durou até as primeiras décadas do século XX, principalmente nos rios Tietê e Pinheiros onde as águas permaneceram limpas por mais tempo.

93. TAUNAY, Afonso de Escragnolle. São Paulo nos primeiros anos: 1554-1601. São Paulo no século XVI. São Paulo: Paz e Terra, 2007, p.159.

94. Ordens Régias, Rev. do Arquivo Municipal LXXVII, p.247-248 apud BRUNO, 1991, p.271. 
O texto da Ordem, originário, portanto, do governo português, defendia a normatização da prática da pesca em São Paulo, já que os métodos utilizados ameaçavam os peixes e a qualidade das águas dos rios. (SANT'ANNA, 2007) Esse edital expunha a preocupação, também do Governo Metropolitano, em preservar os rios como uma fonte de subsistência e, ao mesmo tempo, propunha formas de controle das atividades nos rios. Isso representa uma necessidade crescente de dominação e controle dos rios e águas da cidade.

Em 1808 uma postura determinava a proibição da caça de perdizes e destruição de ninhos no período de procriação num raio de quatro léguas em torno da cidade. "Havia mesmo na época sujeitos que se dedicavam com paixão às caçadas de tôda espécie, não apenas nas vizinhanças da cidade - onde havia campos e matas ainda em abundância - como em locais distantes." (BRUNO, 1991, p.636)

A partir do século XVIII, com a maior diversificação de atividades urbanas, assim como o desenvolvimento da divisão do trabalho, a pesca, fundamental para a subsistência da vila, passou a apresentar a venda de pescados como possibilidade de geração de renda.

Pescadores vendiam peixes em pontos fixos da vila. As ruas do centro eram as que mais abrigavam esse tipo de comércio ${ }^{95}$. Vários desses pontos de venda ficavam próximos aos principais chafarizes e suas aglomerações, onde também eram comercializados outras mercadorias ${ }^{96}$. (SANT'ANNA, 2007, p.85)

Em meados do século XVIII, já existia em São Paulo algum comércio com pequenas lojas e feiras. Por volta da metade do século, a Câmara tomava medidas para a criação de mercados, as chamadas "casinhas". Também nesse período, algumas medidas foram tomadas pelas autoridades municipais restringindo as atividades de comerciantes. Uma vereança de 1749 estabeleceu a venda de peixe fresco na entrada de um

95. Denise Bernuzzi de Sant'Anna, citando Jorge Americano, fala de "um vendedor de peixes chamado Salvador: trazia sobre os ombros um pau roliço de cujas pontas pendiam "dois cestos, a modo dos peixeiros da China: tainha (peixe ordinário), badejo, garoupa, robalo, camarões de graça. Um robalo grande (para o casal e quatro filhos e mais três empregadas) por 1.500 , com camarões de graça, para contrapeso". (AMERICANO, Jorge. São Paulo naquele tempo (18951915), Saraiva, São Paulo, 1957, p.113 apud SANT'ANNA, 2007, p.84)

96. "Aliás, São Paulo do final do século ainda era salpicada por mercadores ambulantes, vendedores de gêneros alimentícios - doces, aves, ovos, verduras, além de salgados preparados com o caldo e a carne dos pescados". (SANT'ANNA, 2007, p.85) 
beco da rua São Bento, "defronte de Manuel de Sousa"97. A seguir, em 1764 , proibiu-se a venda de peixes em estradas, que deveria ser realizada na Lapa e no Carmo. (SANT'ANNA, 2007, p.84)

$\mathrm{Na}$ tentativa de preservar os comerciantes de víveres, a Câmara tentava organizar o comércio evitando a concorrência, como no caso de "negociantes e lojistas de panos e chapéus que vendiam também, nos seus estabelecimentos, açúcar, bebidas e até lombo de porco"98. Até o final do século as "casinhas" passariam a ser pontos importantes de distribuição de gêneros alimentícios. Entretanto, muitos alimentos, como quitutes, pescados e caçados, eram negociados em largos, chafarizes e calçadas de igrejas, onde ambulantes, geralmente negras, vendiam seus produtos em pequenos tabuleiros de madeira.

Na ponte do Acu, no início do século XIX, ficava uma senhora negra chamada Sinhana dos Bolinhos, que vendia bolinhos feitos com peixinhos pescados no Acu.

"Preta velha e esturricada, forra, já há anos, manquitolante como saci-pererê, sempre de pitinho de barro na boca, ficava à tardinha, horas inteiras, naqueles tempos, a atirar pedrinhas nas águas que ali corriam sob a Ponte do Acu. (MARQUES apud SANT'ANNA, 2007, p.47) $)^{99}$

Dessa forma, os rios de São Paulo forneciam sustento, não somente para consumo imediato, ou seja, sem mediadores, mas também possibilitaram a obtenção de alguma renda que não podia ser desprezada, diante do isolamento da vila.

Essa renda, obtida através da coleta direta, e posterior troca de víveres por dinheiro, não configura ainda uma forma desenvolvida de geração de capital. Trata-se de uma renda de subsistência já que é certo que esse dinheiro, conseguido a partir da venda, seria gasto com a compra de outros itens para subsistência ${ }^{100}$. A senhora negra que vende os boli-

97. TAUNAY, Afonso de E. História da cidade de São Paulo no século XVIII (17351765), I, p.161 apud BRUNO, 1991, p.303.

98. TAUnAY, Afonso de E. História da cidade de São Paulo no século XVIII (17351765), I, p.90 apud BRUNO, 1991, p.303.

99. MARQUES, Gabriel. Ruas e Tradições de São Paulo: uma história em cada rua, vol 4 da Coleção História (São Paulo: Conselho Estadual de Cultura, 1966), p. 48 apud SANT'ANNA, 2007 , p.47.

100. No livro terceiro de O Capital, Marx, ao analisar a origem da renda fundiária 
nhos feitos com os peixes do Anhangabaú certamente usaria essa renda para comprar, por exemplo, uma galinha de outro comerciante para consumo próprio, ou ainda um tecido para vestir ou uma vara de pesca. É interessante notar que, diferente dos casos analisados anteriormente, e que envolviam o trabalho escravo negro e indígena, aqui, onde o trabalho não é cativo, a relação do trabalho com a propriedade dos meios de produção ainda é íntegra. O rio e as terras de domínio comum fornecem o sustento necessário à subsistência, ainda que já exista a mediação do dinheiro - o que determina que os "bens da terra" sejam considerados mercadoria - o capital ainda não é a forma dominante.

"Nas formas de sociedade em que ainda não é o capital que executa a função de forçar todo o mais-trabalho e em primeira mão, de apropriar-se ele mesmo de toda a mais-valia, onde portanto, o capital ainda não submeteu a seu controle o trabalho social, ou só o fez esporadicamente, não se pode sequer falar de renda no sentido moderno, da renda como excedente sobre o lucro médio, ou seja, sobre a participação proporcional de cada capital individual na mais-valia produzida pelo capital social global. “101

Aqui, o produtor direto, ou seja, o pescador, dispõe de todo o seu tempo de trabalho para a produção dos seus meios de subsistência. Não existe excedente $^{102}$, no sentido de não existir mais-produção, isto é, produção

capitalista, divide as rendas pré-capitalistas em renda-em-trabalho, renda-em -produto e renda-em-dinheiro (MARX, 1986). Segundo Jorge Oseki, na França sob Luis XIV e Colbert, "tratava-se de modificar a extração e repartição das rendas fundiárias, que eram ainda os recursos principais do Estado e das classes dominantes. Tratava-se de arrancar uma parte dessa renda dos senhores provinciais, bem como dos notáveis burgueses das cidades (mercados agrícolas). As rendas deviam se transformar em renda-em-dinheiro, as rendas-em-trabalho (corvéias) ou renda-em-produto desapareciam, passando para a conta da administração (grandes trabalhos: diques, portos, estradas e canalizações feitos por corvéias)." LEFEBVRE, Henri. De l'Etat, tomo II, 10/18 - Union Génerale d'Éditions, 1976, p.34 apud OSEKI, 1992, p.114.

101. MARX, Karl. O Capital: Crítica da Economia Política, vol.3 Livro Terceiro: O Processo Global da Produção Capitalista, Tomo 2. São Paulo: Abril Cultural, 1986, p.246.

102. "Se os homens não fossem capazes de produzir em um dia de trabalho mais meios de subsistência, portanto, em sentido estrito, mais produtos agrícolas, do que cada trabalhador precisa para sua própria reprodução, se o dispêndio 
acima das necessidades indispensáveis à manutenção do produtor direto.

Dessa forma, o produtor deve ter uma produtividade natural suficientemente grande para que exista a possibilidade de trabalho excedente acima do trabalho necessário "à satisfação de suas necessidades imprescindíveis" (MARX, 1986, p.252). Essa produtividade depende de condições naturais, seja das condições de seus braços, seja das condições do solo e da água.

"Mas a própria possibilidade está presa a condições naturais subjetivas e objetivas. [...] Se a força de trabalho é pequena e as condições naturais de trabalho são precárias, então o maistrabalho será pequeno, mas, por sua vez, também o serão as necessidades dos produtores e, por outro lado, o número relativo de exploradores do mais-trabalho, e, por fim o mais produto em que se materializa esse mais-trabalho pouco rentável para esse número menor de proprietários exploradores." (MARX, 1986, p.252)

Entretanto, essa possibilidade não cria renda de forma espontânea. Isso só ocorre através de coerção e da submissão do produtor direto. $\mathrm{Na}$ economia escravocrata, o escravo trabalha com condições de produção alheias e de forma não autônoma e isso é o que permite que o mais-trabalho seja arrancado dele pelo seu proprietário. Está claro que, diferentemente do escravismo, no caso dos pescadores de São Paulo, o produtor direto ${ }^{103}$ continua a ser o proprietário dos meios de produção e das condições de trabalho para a produção de seus próprios meios de subsistência ${ }^{104}$.

diário de toda a sua força de trabalho apenas desse para produzir os meios de subsistência indispensáveis para suas necessidades individuais, então não se poderia falar de mais-produto ou de mais valia. Uma produtividade do trabalho agrícola que transcenda as necessidades individuais do trabalhador é a base de toda a sociedade e, sobretudo, é a base da produção capitalista, que libera da produção dos meios de subsistência uma parte sempre crescente da sociedade [...]" (MARX, 1986, p.247)

103. "De acordo com os pressupostos, o produtor direto se encontra na posse de seus próprios meios de produção, as condições de trabalho objetivas necessárias à realização de seu trabalho e à geração de seus meios de subsistência; ele exerce de modo autônomo sua agricultura bem como a indústria rural caseira ligada a ela." (MARX, 1986, p.251)

104. "A forma econômica específica em que se suga mais-trabalho não pago dos 
Sob as condições de abundância de terras e fontes de subsistência, como era o caso de São Paulo, o mais-trabalho só poderia ser extraído dos produtores diretos mediante a apropriação da terra e o fim das fontes de subsistência. Tornava-se necessário, portanto, a criação de relações pessoais de dependência, sejam elas quais fossem, seja preso em uma senzala, seja preso à terra como um acessório dela.

Apesar do avanço representado pela estruturação da pequena rede de distribuição, com o passar dos anos, o fornecimento de água em São Paulo continuava extremamente deficitário. A falta de água nas bicas e chafarizes era uma constante. Até o fim do século, outros condutos de derivação foram construídos, complementando o sistema, mas mantendo sempre a insuficiência diante da demanda e a precariedade como principais características. A falta de água fazia com que a municipalidade estudasse a possibilidade de conseguir água em outras localidades e bacias de outros rios, como o Cambuci, já que as águas dos rios e córregos da vila já não apresentavam condições de consumo. Entretanto, as condições econômicas da cidade não permitiam que tais planos se viabilizassem.

Os despejos continuavam acontecendo diretamente nos rios. No Anhangabaú,

“[... nas proximidades do córrego e da ponte do Acu atiravase ainda o lixo da cidade. O mesmo acontecia com a várzea do Carmo, beirando o Tamanduaté́, onde se faziam então os despejos de uma parte da povoação, soltavam-se animais, sujeitos

produtores diretos determina a relação de dominação e servidão, tal como esta surge diretamente da própria produção e, por sua vez, retroage de forma determinante sobre ela. [...] É sempre na relação direta dos proprietários das condições de produção com os produtores diretos - relação da qual cada forma sempre corresponde naturalmente a determinada fase do desenvolvimento dos métodos de trabalho, e portanto a sua força produtiva social - que encontramos o segredo mais íntimo, o fundamento oculto de toda construção social e, por conseguinte, da forma política das relações de soberania e de dependência, em suma, de cada forma específica de Estado. Isso não impede que a mesma base econômica - a mesma quanto às condições principais - possa, devido a inúmeras circunstâncias empíricas distintas, condições naturais, relações raciais, influências históricas externas etc., exibir infinitas variações e graduações em sua manifestação, que só podem ser entendidas mediante análise dessas circunstâncias empiricamente dadas." (MARX, 1986, p.251-252) 
preguiçosos caçavam e as lavadeiras batiam roupa."105 (BRUNO, 1991, p.198)

No início do século XIX, as Atas da Câmara registravam a falta de água para abastecimento dos moradores de São Paulo, onde se conseguia água em apenas um "único chafariz que havia na cidade" (BRUNO, 1991, p.288), provavelmente o da Misericórdia. O provimento de água foi incrementado a partir da construção de uma caixa d'água e de dois condutos, um aberto próximo à ponte do Lorena e outro próximo à ponte do Marechal. Entretanto, o abastecimento continuava deficiente em quantidade e qualidade.

"No centro da parte principal da cidade [...] havia somente o chafariz da Misericórdia, com quatro bicas que nem sempre corriam com abundância. [...] Sua água não valia nada, pois vinha do Tanque Reúno e em seu percurso atravessava um rêgo descoberto, parte do qual passava por um arrabalde sujo chamado rua do Rêgo, cujo ar era empestado [...] e cujo chão era juncado de caveiras de boi, de sabugos de chifres, de ossos e outros resíduos imundos, porque os seus moradores eram qui-

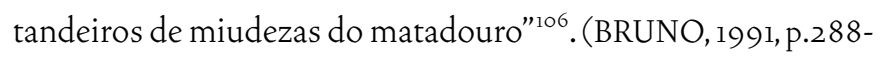
289)

Longe de ser uma característica da região, a escassez de água, um fato relacionado a questões sociais e políticas, acirrava a disputa pela água. Os conflitos eram recorrentes em torno das águas dos rios e chafarizes da vila, motivando atos deliberados de posse e impedimento ao acesso às fontes de água e aos rios.

Próximo do final do século XVIII, a escassez de água aparecia como uma oportunidade de geração de renda pelo transporte e distribuição de água pela vila. Um barril de água podia ser vendido por 40 réis no centro urbanizado (SANT'ANNA, 2007). A população, que se abastecia nas bicas e chafarizes da cidade, passou também a comprar água de vendedores ambulantes conhecidos como aguadeiros. Esses vendedores

“[...] deixavam um barrilzinho debaixo da torneira da carroça

105. SAMPAIO, Teodoro. São Paulo no tempo de Anchieta apud BRUNO, 1991, p.198. 106. BUENO, Francisco de Assis Vieira. A cidade de São Paulo apud BRUNO, 1991, p.288-289 
e, enquanto ele se enchia lentamente, despejavam outro no interior da casa - traçando a carvão na parede, cada dia, um risco por vasilha fornecida para cobrança no final do mês". (BRUNO, 1991, p.1121)

O movimento dos aguadeiros fazia parte do cotidiano da cidade, tendo livre acesso às fontes, chafarizes e residências. Segundo Sant'Anna essa prática envolvia certa sociabilidade já que o controle do consumo era

“[... estabelecido na relação direta entre moradores e aguadeiros dentro das residências e, em alguns casos, a pouca cerimônia desses comerciantes caía na rotina doméstica. Vários deles assumiam a tarefa de despejar o líquido dentro de potes e vasos de barro que ficavam sobre prateleiras situadas nos locais mais frescos da casa: a água mantinha-se, assim, em excelente temperatura." (SANT'ANNA, 2007, p.103)

Já no século XIX, muitos desses comerciantes visavam o domínio do comércio e da distribuição da água na cidade. Além da escassez de água nos chafarizes, o fato de os rios mais próximos encontrarem-se relativamente sujos, como o Anhangabaú e o Tamanduateí, favorecia a venda de água pelos aguadeiros. As Atas da Câmara registram que esses comerciantes buscavam água em "pontos de água" distantes da vila e que serviam uma água de qualidade muito boa. Mesmo assim haviam rumores de que alguns comerciantes vendessem água impura coletada nos rios próximos. (SANT'ANNA, 2007)

Há registros de eventos em que aguadeiros sabotavam o funcionamento de chafarizes ou até mesmo depredavam esses equipamentos como forma de garantir o seu negócio, causando revolta em moradores e cativos. As disputas

“[...] resultavam frequentemente da reação de cativos aos abusos dos aguadeiros. Conhece-se o ofício de um fiscal da cidade em 1864, pedindo providências das autoridades contra esses abusos que se davam em vários chafarizes. Os aguadeiros não apenas praticavam estragos, mas impediam também que os escravos e outras pessoas se servissem de água enquanto não estivessem cheias as pipas deles."(BRUNO, 1991, p.623) 
O fato é que o abastecimento de água de São Paulo não era suficiente para servir toda a população e essa era a principal causa dos conflitos em torno dos rios e chafarizes. Nesse sentido, os aguadeiros tiveram um importante papel na vida da $\operatorname{cidad}^{107}$, complementando o serviço de distribuição e água.

A comparação realizada por viajantes caracterizava a estrutura de distribuição de água de São Paulo como insuficiente. O naturalista Carl Von Martius, em passagem pela vila de São Paulo no primeiro quarto do século XIX, registrou que o abastecimento de água era bastante inferior ao de Vila Rica, por exemplo, que contava com catorze chafarizes. ${ }^{108}$

Bicas, fontes e chafarizes, por onde se distribuía água publicamente, continuavam a oferecer água gratuitamente aos moradores da vila. Esses equipamentos situavam-se em largos e praças, locais que logo se tornaram verdadeiros centros e referência geográfica dentro da vila. Nos lugares onde a água era oferecida aglomeravam-se escravos, índios, viajantes, empregados, pobres, ambulantes, animais e rapidamente tornaram-se o centro da vida social de uma parcela significativa da população, principalmente de escravos (SANTOS, 2011, p.42-43). O cotidiano da cidade era marcado pelo movimento de coleta de água entre as casas e os chafarizes.

Conflitos nessas localidades eram comuns e logo a presença da água passou a representar a desvalorização dos imóveis próximos. Segundo Antonio Egídio Martins, logo depois da inauguração do chafariz da Misericórdia em 1792, uma família que residia no largo se mudou de lá “[...] por não poder suportar as cenas desagradáveis que eram de costume dar-se no lugar do aludido Chafariz entre os carregadores de água, os quais, na sua maioria, eram escravos". (MARTINS, s/d)

Afonso A. de Freitas afirma que alguns desses equipamentos viviam rodeados de gente, dia e noite,

107. Segundo Denise Bernuzzi de Sant'Anna, antes da fundação do Corpo de Bombeiros, "eram os aguadeiros, a Guarda Urbana e os próprios moradores que deviam apagar o fogo e acudir os flagelados. Os sineiros davam o alarme. Uma postura de 1852, sobre os incêndios na cidade, apresentada numa seção da Câmara, prescrevia que "os proprietários ou inquilinos das casas da rua ou largo em que for o incêndio que tiverem poços serão obrigados a franquear a entrada para os mesmos poços a fim de se tirar a água". Arquivo Municipal de São Paulo, Departamento de Cultura, São Paulo, Atas da Câmara Municipal de São Paulo, 6 de fevereiro de 1852, p.35 apud SANT'ANNA, 2007, p.90.

108. MARTIUS, Carl Von. Viagem pelo Brasil, I, p.311 apud BRUNO, 1919, p.287 nota 145 . 
"[...] em geral escravos cujas vozes se ouviam de longe. De noite a concorrência era ainda maior. Em tempo de seca, quando o fornecimento escasseava [...] havia às vezes luta em que se quebrava muito pote de barro [...]". (FREITAS, 1991, p.288)

Os chafarizes promoviam a reunião de diversas pessoas em torno da água, o que fazia desses equipamentos pontos de intensas trocas, e não somente de $\operatorname{conflitos}^{109}$. Por esse motivo se tornaram importantes locais de sociabilidade, despertando diversos interesses e a necessidade, por parte da organização municipal, de intervir nesses espaços.

Como tentativa de controlar esses espaços e, por consequência, controlar a água, a Câmara passou a limitar os horários de uso dos chafarizes que passaram a abrir às 5 h e geralmente estavam fechados às $21 \mathrm{~h}$ ou $22 \mathrm{~h}$, sendo que em muitos desses equipamentos foram instaladas grades de fechamento.

No início do século XIX, a vila contava com diversas bicas e chafarizes, o que não significa que o abastecimento de água fosse suficiente ou regular. A maior parte desses chafarizes passavam longos períodos quebrados ou inoperantes, fazendo com que partes da vila ficassem frequentemente sem água. A população via-se obrigada a se servir das águas dos rios Tamanduateí e Anhangabaú. Apesar de sujos, esses rios continuavam a servir água para a maior parte das pessoas que viviam em São Paulo. Essa contaminação também era resultado da atividade de lavagem de roupas, que acontecia principalmente nas margens do rio Tamanduateí.

"Da Rua Glicério e de toda a encosta da colina central da cidade, desciam lavadeiras de tamancos, trazendo trouxas e tábuas de bater roupa. À beira da água, juntavam a parte traseira à dianteira da saia, por um nó no apanhado da saia, a qual tomava aspecto de bombacha. Sugavam-na pela parte superior, amarravam-na à cintura com barbante, de modo a encurtá-la até os joelhos ou pouco acima, tomando agora o aspecto de calção estofado. Deixavam os tamancos, entravam n'água e debruçavam-se sobre o rio, sem perigo de serem mal vistas pelas costas." (AMERICANO, 1957, p.146-147)

109. Denise Bernuzzi de Sant'Anna lembra que "a imprensa e os documentos de natureza policial tendem a chamar a atenção sobre os chafarizes unicamente nos momentos de brigas e depredação deles". (SANT'ANNA, 2007, p.98). 
A atividade das lavadeiras tinha um significado importante no contexto social de São Paulo. Em uma cidade onde faltava água para beber e para tomar banho, a limpeza era uma qualidade que se ostentava através das roupas que se vestia.

“Daí a importância extraordinária das lavadeiras e engomadeiras: seus ofícios viabilizavam a ostentação pública da limpeza física e moral de seus patrões. Essa tendência se fortaleceu à medida que a cidade cresceu e ampliou seus espaços de distinção social. [...] Dentro das moradias, toalhas e lençóis de algodão, linho ou bretanha, fronhas de cambraia e guardanapos alvejados graças ao uso de água fervida também contribuíam para exibir os níveis de limpeza e boa educação de seus proprietários." (SANT'ANNA, 2007, p.124)

Os registros feitos por memorialistas dão conta de que essas mulheres eram em sua maioria negras forras. Entretanto, é possível supor que essa atividade também tenha sido exercida por escravas, principalmente até o século XVIII. A falta de água também afetava essa atividade, gerando conflitos e a consequente intervenção das autoridades municipais.

“[...] quando da falta da água [...]. Numerosos grupos de mulheres apressadas se dirigiam em direção à Várzea do Carmo. A maioria eram ex-escravas e mamelucas, sendo poucas as mulheres brancas. [...] Acontecia que muito antes de se acomodarem, cada qual em seus lugares, já se iniciava a discussão que era acompanhada de impropérios e palavrões e terminava em brigas - tudo isso para a disputa de melhores lugares. Raro o dia em que a polícia não era chamada a intervir [...]."110 (SANTOS, 2000, p.7)

As várzeas do Tamanduateí foram caracterizadas por Saint-Hilaire ${ }^{111}$, no começo do século XIX, como sendo um local muito pitoresco e animado pela presença de lavadeiras que lavavam roupas próximo às pontes, na beira do rio. As várzeas eram muito pantanosas nas proximidades do Tamanduateí, fazendo com que as sujeiras provenientes de despejos e

\footnotetext{
110. SESSO JR., Geraldo. Retalhos da velha São Paulo, 1983, p.34.

111. SAINT-HILAIRE, Auguste de. Viagem à província de São Paulo. São Paulo: Martins/Edusp, 1972, p.177.
} 
lavagem de roupas se acumulassem e causassem maior transtorno que em outros rios da cidade.

Ernani Silva Bruno alerta para o fato de, durante a primeira viagem de Saint-Hilaire à São Paulo, as várzeas desse rio estarem transformadas devido a intervenções no seu leito ${ }^{112}$. A várzea do Carmo era um lamaçal, gerando diversos protestos e prejuízos à cidade. Isso motivou a Câmara a intervir no curso desse rio, na tentativa de drenar a várzea e fazer com que a água fluísse mais facilmente.

Entre 1841 e 1848, as primeiras obras de retificação foram executadas nessa várzea visando seu enxugamento e "aformoseamento", já que em época de chuvas os rios que cercavam a cidade transbordavam quase transformando a colina em uma ilha. A obra foi uma iniciativa do Presidente da Província, Pires da Motta, e aconteceu sob a direção do engenheiro alemão Karl Abrahan Bresser, que construiu um canal paralelo ao curso original do rio, mais distante do sopé da colina e com maior profundidade para aumentar sua capacidade de vazão ${ }^{113}$. Parte dos resultados dessa intervenção podem ser observados no mapa das páginas 146-147 e 148-149.

Essa obra afastou o problema mas não o resolveu. O problema dos transbordamentos e as águas sujas do Tamanduateí continuaram a molestar a cidade. Além disso, o canal acabou com uma parte do rio que era conhecida com sete voltas, uma série de meandros que podiam ser avistados da colina. A verdade é que as intervenções colaboraram para agravar a situação de insalubridade da várzea já que depois dessas obras registrava-se que, além de terem destruído os passeios públicos que ali existiam,

“[...] são notórias as consequências em prejuízo público da população, na propagação dos insetos que infestam geralmente

112. “[...] sabe-se que essa várzea, na época da viagem do naturalista francês - e segundo dizia um registro geral da Câmara em 1822 - estava reduzida simplesmente a um pântano contínuo, devido a ter se consentido que certas pessoas atendendo apenas às suas conveniências tivessem desviado de seu leito natural as águas do Tamanduateí." (BRUNO, 1991, p.212)

113. Nessa primeira intervenção," [...] abriu-se uma vala que, retificando a curva do rio onde foi depois o largo do Hospício, fazia com que o Tamanduateí marginasse a faixa de terreno onde mais tarde se desenhou a rua da Figueira. Em 1810 fizera-se uma segunda vala pelo centro da várzea, ao mesmo tempo que se construía o atêrro em continuação da ladeira do Carmo". (BRUNO, 1991, p.212213) 
tôda esta cidade, na alagação das margens do rio e vargeados por êle derrigados, cujas águas estagnadas anualmente produzem hálitos pestíferos de ervas curtidas e corpos corruptos, cujos eflúvios, comunicados aos habitantes pela atmosfera motivam as frequêntes epidemias que oprimem a humanidade com indizível estrago [...]." ${ }^{114}$ (BRUNO, 1991, p.350)

Essas obras também afetavam a navegação fluvial ao mudar o curso do rio e sobretudo pela lentidão desses empreendimentos "que deviam ser trabalhos feitos com muita morosidade" (BRUNO, 1991, p.213) Segundo José Geraldo Simões Jr. ${ }^{115}$, já nessas primeiras intervenções no curso do Tamanduateí, a navegação nesse rio tornou-se inviável.

Essa intervenção no Tamanduaté é importante pois marca o momento em que esse rio, a partir de sua poluição e o fim na navegação, passaria a fornecer cada vez menos meios de subsistência para a população da cidade, apesar de muitos moradores ainda subsistirem através de atividades proporcionadas por suas águas.

Ao mesmo tempo em que a navegação fluvial na cidade tinha esse revés, as comunicações por terra foram se ampliando. Os investimentos na agricultura aliados ao desenvolvimento das atividades urbanas e maior atividade comercial na cidade ressignificaram os antigos caminhos quinhentistas que levavam ao centro da vila, agora mais ligados à existência dessas atividades.

114. Registro Geral da Câmara da Cidade de São Paulo, XVII, p.272 apud BRUNO, 1991, p.350.

115. SIMÕES JR, José Geraldo. Anhangabaú: história e urbanismo. São Paulo: Senac/Imprensa Oficial do Estado de São Paulo, 2004. 


PARTE II - APROPRIAÇÃO DA TERRA, DO HOMEM E DA ÁGUA 

Enquanto o trabalho é escravo, a terra é destituída de valor e não equivale ao capital mesmo quando tem um preço. Segundo José de Sousa Martins ${ }^{116}$, tanto no regime de trabalho escravo quanto no regime de trabalho livre, a renda capitalizada é a principal forma do capital. A ocupação da terra era feita pela simples posse por pequenos lavradores ou pelas cartas de sesmaria, que eram a forma legal de obtenção de terras por grandes fazendeiros. Não existindo um mercado imobiliário capaz de garantir retorno, a comercialização de trabalhadores cativos ${ }^{117}$ representava maiores interesses.

"Nesse sentido, o principal capital do fazendeiro estava investido na pessoa do escravo, imobilizado como renda capitaliza$\mathrm{da}$, isto é, tributo antecipado ao traficante de negros com base numa probabilidade de ganho futuro. O fazendeiro comprava a capacidade de o escravo criar riqueza. De fato, a terra sem tra-

116. MARTINS, José de Souza. O cativeiro da terra, São Paulo: Livraria Editora Ciências Humanas, 1981.

117. Sobre o trabalho escravo nas fazendas, explica Martins que "esse trabalho era, como sabemos, trabalho compulsório. Entretanto, o caráter compulsório do trabalho não provinha da escassez absoluta de mão-de-obra, mas do fato de que a oferta desses trabalhadores no mercado era regulada pelo comércio negreiro." (MARTINS, 1981, p.25) 
balhadores nada representava em termos econômicos; enquanto isso, independentemente da terra, o trabalhador era um bem precioso." (MARTINS, 1981, p. 26)

Além disso, o capital imobilizado na pessoa do escravo servia como garantia em empréstimos realizados pelos fazendeiros para a ampliação dos negócios da fazenda. Quase todo o capital envolvido na produção era proveniente das hipotecas lançadas sobre a propriedade dos escravos.

Com a proibição do tráfico em 1850 , o preço dos escravos disparou, aumentando o capital disponível aos fazendeiros. Esse fato também explicaria o avanço do café do Rio de Janeiro para os municípios paulistas próximos ao limite entre as duas províncias, no Vale do Paraíba. Assim,

“[...] a expansão do crédito, que aparentemente, beneficiava a produção, encerrava uma contradição: a elevação do preço do escravo incrementa a base de obtenção de empréstimos hipotecários ao mesmo tempo em que a expansão dos empreendimentos cafeeiros ficava na dependência de uma maior imobilização de capital, sob forma de renda capitalizada na pessoa do cativo. Essa situação, portanto, não beneficiava o fazendeiro, mas sim o traficante, incrementando o tributo que a produção devia pagar ao comércio". (MARTINS, 1981, p. 28)

Em São Paulo, com a crescente demanda por trabalhadores escravos, trazidos de outras províncias, a tendência era aumentar a imobilização dos recursos dos fazendeiros sob a forma de renda capitalizada, enquanto que os tributos pagos aos traficantes aumentavam mais rapidamente que a produtividade do trabalho. A única solução possível seria a abolição da escravatura.

É provável que isso já tenha sido previsto antes da data da proibição do tráfico, em 1850, visto que nesse mesmo ano foi promulgada a lei que incentivou o desenvolvimento de uma política de imigração ${ }^{118}$

118. Segundo Paulo Cesar Xavier Pereira "a política imigratória foi forjada pelos cafeicultores de São Paulo e subvencionada pelos cofres públicos, conseguindo carrear a disponibilidade de trabalho europeu para o complexo cafeeiro" (PEREIRA, 2004, p. 39 nota 1). Segundo Lúcio Kowarick, em "Escravos, Párias e Proletários", a "opção arquitetada pelo grande fazendeiro de café foi a importação em massa da mão-de-obra, que empobrecida na Europa, não tinha outra alternativa senão a de vender, por sinal a preços aviltantes, sua força de trabalho. 
de colonos estrangeiros que respondesse à demanda de trabalhadores livres nas fazendas de café. (MARTINS, 1981)

Entretanto, a ampla disponibilidade de terras devolutas por todas as partes do país poderia constituir um grave problema, já que essas terras estavam, teoricamente, livres para serem apossadas não só por negros libertos mas também por qualquer trabalhador livre, nacional ou imigrante. ${ }^{119}$

O sistema de concessão de sesmarias, que impunha obstáculos à simples ocupação da terra, tinha sido abolida com a independência do Brasil na década de 1820 , ficando as terras devolutas do Império, "desprotegidas" até a promulgação da Lei de Terras, em 1850, quando foi instituído que o acesso à terra não se daria de outra forma que não fosse pela compra, o que, por si só, dificultava consideravelmente o acesso à propriedade da terra. A promulgação da Lei de Terras apenas representou a formalização da propriedade privada da terra no Brasil.

Em 1854, com a regulamentação da Lei de Terras, todas as ocupações e títulos de sesmarias foram validados, e a partir disso, surgiu no Brasil uma indústria de falsificação de títulos de propriedades, "sempre datados de época anterior à data da lei, registrados em cartórios oficiais, geralmente mediante suborno aos escrivães e notários" (MARTINS, 1981, p. 29).

O acesso à propriedade da terra era, quase sempre, impossível ao antigo escravo e ao imigrante, seja por ignorância ou por falta de recursos financeiros para despesas judiciais ou subornar autoridades. Dessa forma, "a impossibilidade de ocupação sem pagamento das terras devolutas, recriava as condições de sujeçção do trabalho que desapareceriam com o fim do trabalho cativo". (MARTINS, 1981, p. 29)

\footnotetext{
[...] Na atividade cafeeira ocorreu a superexploração do trabalhador, porque a abundância da mão-de-obra, predominantemente estrangeira em certas zonas e nacional em outras, possibilitou deteriorar os salários". (KOWARICK apud PEREIRA, 2004, P. 39 nota 1)

119. "Ainda no mesmo ano de 1850 , foram adotados procedimentos legais com vistas à substituição dos trabalhadores cativos. O objetivo sugerido foi o de promover a livre imigração do exterior. Todavia, nesse ponto refletiu-se o fato de que, no Brasil, a escravidão era o principal recurso institucional para garantir aos fazendeiros uma oferta de força de trabalho compatível com a demanda de seus empreendimentos. Se a escravidão cessasse nada poderia prevenir o deslocamento dos antigos e novos trabalhadores para as terras livres da fronteira agrícola, onde poderiam tornar-se trabalhadores autônomos em suas próprias terras." (MARTINS, 1981, p. 122)
} 
A questão do crédito hipotecário, que antes era lastreado no capital investido no escravo, foi solucionada, em 1873, com a expansão do crédito hipotecário a todos os municípios das províncias de São Paulo, Paraná e Santa Catarina, tendo como suporte a própria fazenda, representada sobretudo pelas plantações, por suas instalações e edifícios (MARTINS, 1981, p. 30). Isso permitiu que o escravo fosse substituído não só como trabalhador, mas também como garantia hipotecária.

Faltava resolver a questão do livre acesso às terras devolutas do Império, evitando que o trabalhador livre simplesmente tomasse posse ou comprasse alguma porção de terra, tornando-se, assim, trabalhador autônomo e proprietário, deixando o trabalho nas lavouras de café. Nesse sentido, ocorreram diversos debates entre os grupos interessados sobre a melhor maneira de substituição do trabalho escravo pelo trabalho livre. A solução adotada evitou que o imigrante tivesse acesso à terra de forma imediata, devendo os colonos conquistar a propriedade da terra através do trabalho, de forma que se condicionou o acesso à propriedade, que raramente aconteceu, ao trabalho prévio na fazenda de café. (MARTINS, 1981)

Paulatinamente, o capital antes investido na pessoa do cativo, agora liberado, passaria a ser aplicado na propriedade fundiária.

"Combinava-se de novo, sob outras condições históricas e, portanto, de outra forma, aparentemente invertidos, os elementos de sustentação da economia colonial. A renda capitalizada no escravo transformava-se em renda territorial capitalizada: num regime de terras livres, o trabalho tinha que ser cativo; num regime de trabalho livre, a terra tinha que ser cativa. No Brasil, a renda territorial capitalizada não é essencialmente uma transfigurada herança feudal. Ela é engendrada no bojo da crise do trabalho escravo como meio para garantir a sujeição do trabalho ao capital, como substituto da expropriação territorial do trabalhador e substituto da acumulação primitiva na produção da força de trabatho." (MARTINS, 1981, p. 32)

Havia manifesto interesse, por parte dos produtores de café, em manter afastados da propriedade da terra negros alforriados, assim como trabalhadores nacionais e imigrantes, como forma de sujeição do trabalho ao capital, mediante a implementação do regime de trabalho livre. Tal operação foi fundamental para o sucesso das transformações sociais e 
econômicas então pretendidas, sendo necessário impedir o antigo escravo e o imigrante, já expropriados, ao acesso à propriedade e também a qualquer meio de subsistência.

A cultura do café implicou modificações na base da produção econômica da província, que culminaram com a abolição da escravatura e a imigração europeia, introduzindo transformações na cidade de São Paulo, notadamente nas formas de produção e elaboração material do espaço da cidade. Nesse, assim como nas lavouras, aconteceram transformações na forma de valorização do capital, passando a se concentrar, principalmente, na propriedade imobiliária. Isso também determinou como os rios de São Paulo seriam apropriados pois, como vimos, eles se caracterizavam como o principal meio de subsistência para os moradores da cidade.

\section{TERRA E ÁGUA: DO DOMÍNIO COMUM AO DOMÍNIO PARTICULAR}

Segundo Ernani Silva Bruno ${ }^{120}$, em 1830, São Paulo, apesar de ser a capital da província e desde 1823 detentora do título de Imperial Cidade, não passava de uma pobre povoação, "nem a sua região nem a sua província podiam lhe dar elementos de prosperidade e de destaque dentro dos quadros da economia brasileira da época" (BRUNO, 1991). A aparência $\mathrm{da}$ cidade pouco havia mudado do início a meados da segunda metade do século XIX, permanecendo contida na colina e balizada pelo triângulo apenas ensaiando a ocupação da margem esquerda do Anhangabaú.

De fato, se observarmos os mapas referentes a esse período, é possível constatar que a parcela da cidade efetivamente arruada e ocupada praticamente não se alterou durante todo o século XIX, como pode ser visto nos mapas de 1844/47 e 1881 (páginas 144-145 e 146-147). Entretanto, isso contrasta com a importância dos fatos ocorridos nesse período, pois, enquanto o núcleo urbanizado pouco mudava, acontecimentos sociais, políticos e econômicos definiram as bases da elaboração material da cidade que aconteceria a partir do final do século XIX.

Dentre esses acontecimentos, a Lei de Terras de 1850, as disputas políticas entre os governos Municipal e Provincial, além de transformações introduzidas pelo cultivo do café no estado foram responsáveis por

120. BRUNO, Ernani Silva. História e Tradições da cidade de São Paulo: vol.ı Arraial de Sertanistas (1554-1828). São Paulo: Hucitec, 1991. 
determinar a forma como se daria a produção do espaço da cidade. Esses acontecimentos também determinaram a forma como os espaços de uso comum, especialmente as terras que continham os rios e as águas da cidade, seriam apropriados e controlados.

A lei n. 601 de 18 de setembro de 1850 , instituiu que as terras devolutas do Império, ou aquelas de domínio público, a partir daquela data, medidas e demarcadas, só poderiam ser adquiridas exclusivamente por meio da compra. A Lei de Terras representou a formalização da propriedade capitalista da terra no Brasil e encerrou o antigo sistema de concessões e posses ${ }^{121}$.

Segundo Mônica Silveira Brito ${ }^{122}$, a Lei de Terras se organizava em consonância com o processo de introdução de mudanças nas relações de produção, cujos objetivos incluíam uma adequação das relações entre o regime de propriedade da terra e o processo de substituição de um regime baseado no trabalho escravo por outro baseado no trabalho livre. De forma geral, "era a definição de critérios para a apropriação privada das terras destinadas à produção agrícola, portanto, o que estava entre suas principais preocupações". (BRITO, 2007, p.50)

Sobre as consequências da aplicação dessa lei no Brasil, segundo Raquel Rolnik ${ }^{123}$,

121. A lei, "dispõe sobre as terras devolutas no Império, e acerca das que são possuídas por titulo de sesmaria sem preenchimento das condições legais, bem como por simples titulo de posse mansa e pacifica; e determina que, medidas e demarcadas as primeiras, sejam elas cedidas a titulo oneroso, assim para empresas particulares, como para o estabelecimento de colonias de nacionaes e de extrangeiros, autorizado o Governo a promover a colonisação extrangeira na forma que se declara D. Pedro II[...]: Art. $1^{\circ}$ Ficam prohibidas as acquisições de terras devolutas por outro titulo que não seja o de compra. [...] Art. $3^{\circ}$ São terras devolutas: $§ 1^{\circ}$ As que não se acharem applicadas a algum uso publico nacional, provincial, ou municipal. $\S 2^{\circ}$ As que não se acharem no dominio particular por qualquer titulo legitimo, nem forem havidas por sesmarias e outras concessões do Governo Geral ou Provincial, não incursas em commisso por falta do cumprimento das condições de medição, confirmação e cultura. § $3^{\circ}$ As que não se acharem dadas por sesmarias, ou outras concessões do Governo, que, apezar de incursas em commisso, forem revalidadas por esta Lei. § $4^{\circ}$ As que não se acharem occupadas por posses, que, apezar de não se fundarem em titulo legal, forem legitimadas por esta Lei." Lei n. 601 de 18 de setembro de 1850.

122. BRITO, Mônica Silveira. Modernização e tradição: urbanização, propriedade da terra e crédito hipotecário em São Paulo na segunda metade do século XIX. 2007. Tese de Doutorado apresentada ao Departamento de Geografia da FFLCH-USP, $200 \%$

123. ROLNIK, Raquel. A Cidade e a Lei: legislação, política urbana e territórios na 
"[...] a promulgação da Lei de Terras marca um corte fundamental na forma de apropriação da terra no Brasil, com grandes consequências para o desenvolvimento das cidades. A partir de sua promulgação, a única forma legal de posse da terra passou a ser a compra devidamente registrada. Foram duas as implicações imediatas dessa mudança: [...] o reconhecimento do direito de acesso se desvincula da condição de efetiva ocupação, e sua monetarização, o que significa que a terra passou a adquirir plenamente o estatuto de mercadoria." ${ }^{124}$

Esse novo regime de terras, introduzido pela lei de 1850, foi associado ao projeto de importação de mão de obra de colonos europeus livres para as lavouras de café, o que, segundo José de Souza Martins, exigiu a organização de um movimento de transição. Afinal, como vimos, o acesso à terra, no Brasil, foi livre enquanto o trabalho foi cativo, e no momento em que se implantou o trabalho livre a terra é que passou a ser cativa. (MARTINS, 1981)

É importante notar que essa lei refere-se, principalmente, às terras rurais destinadas à lavoura e criação, e ainda que mencione as terras urbanas e as terras destinadas ao crescimento dos núcleos, isso acontece de maneira muito imprecisa. No caso de São Paulo, as terras de uso comum e por consequência, os rios da cidade, estavam contidos nesses espaços contemplados com uma simples menção na lei.

A lei determinou que as terras urbanas que ainda faziam parte do patrimônio municipal, ou seja, terras de domínio comum, diferente do que foi estabelecido para as terras rurais, eram uma exceção, não estando, portanto, submetidas ao mercado, isto é, à compra e venda. Essas áreas permaneceram, mesmo após 1850 , sendo concedidas da mesma forma como vinha se fazendo antes da lei, ou seja, por meio do arrendamento ou enfiteuse $e^{125}$.

cidade de São Paulo, São Paulo: Studio Nobel: Fapesp, 2003.

124. ROLNIK, Raquel. A Cidade e a Lei: legislação, política urbana e territórios na cidade de São Paulo, São Paulo: Studio Nobel: Fapesp, 2003, p.23.

125. Como explica Mônica Silveira Brito, enfiteuse é "um tipo de aforamento de caráter perpétuo, a partir do qual o proprietário (o Conselho municipal ou a igreja, na grande maioria dos casos), mantendo-se senhorio do domínio direto das terras, transfere ao enfiteuta apenas o domínio útil, mediante o pagamento de um foro anual previamente estabelecido. Além de perpétuo, o direito adquirido pela enfiteuse (isto é, o domínio útil) pode ser vendido, desde que respeitado o direito de preferência do senhorio direto e que pago a este o laudêmio, uma taxa 
Apesar de não ter implicado em uma mudança significativa na forma como se concedia terras nos núcleos, vilas e cidades, a lei de $1850 \mathrm{fez}$ com que, em São Paulo, uma parcela significativa das terras que circundavam o núcleo não fossem consideradas. O texto da lei ignora o patrimônio do Conselho, que eram as áreas de uso comum e que, nesse momento continham parte importante dos rios da cidade.

Essa lei, que visava a regulamentação das formas de apropriação das terras rurais, e já não considerava parte importante das terras do contexto urbano, não menciona os rios e águas, permanecendo esses recursos ignorados e em segundo plano, ainda que tenham sido diretamente afetados.

O texto da lei determinava ainda que se faria exceção, não estando, portanto, submetidas à compra e venda as áreas que estivessem no perímetro de cobrança da décima urbana, lei de 1808, que incidia sobre os edifícios urbanos. A lei que determinava a cobrança da décima urbana definiu que área urbana era aquela que se encontrasse arruada e edificada, área essa que, em São Paulo, era muito reduzida se comparada ao perímetro do rocio. Criou-se assim uma grande área remanescente em volta do núcleo sobre a qual nenhuma dessas leis se referia.

Dessa forma, em São Paulo, no início da segunda metade do século XIX, momento da promulgação da Lei de Terras, os limites territoriais que correspondiam ao rocio certamente não equivaliam ao da área propriamente urbana, ainda que a contivesse. (BRITO, 2007)

O que deve ser dito sobre o raio de meia légua, ou 3.300 metros, do rocio é que ele simplesmente não é notado nos mapas desse período, e muito menos percebido na cidade, onde não se nota qualquer referência ou resíduo na morfologia urbana da cidade. Não se nota a existência desse perímetro, ou mesmo das terras de uso comum. Isso pode ser observado nos mapas das páginas 144-145 e 146-147, de 1844/47 e 1881, que são alguns dos únicos mapas de São Paulo desse período, nos quais esses espaços de uso comum simplesmente não aparecem. É especialmente importante a constatação de que esses domínios comuns não implicaram uma evidência física nem uma diferenciação entre o que eram as terras do patrimônio do Conselho, e as terras destinadas à compra e venda, quando esse tipo de limite costuma aparecer e permanecer no espaço. Além dos termos que denominavam os espaços de uso comum,

pré-estabelecida, de responsabilidade do enfiteuta". (BRITO, 2007, p.50) 
as evidências físicas de sua existência tendiam a desaparecer e a sua ausência nos mapas é uma evidência desse fato.

Ainda sobre esses dois mapas, é possível notar como os rios já aparecem totalmente em segundo plano também nas representações da cidade. O rio Tamanduateí, sempre descrito como um rio que regularmente transbordava, é representado apenas por seu leito menor, evidenciando que as terras das várzeas não eram consideradas parte do rio ou que o estado de transbordamento não era seu estado real. Isso acontece no momento em que as várzeas do Tamanduateí eram objeto de disputa. Mesmo o Tietê, considerado o mais importante da região, aparece apenas parcialmente e incompleto. Quando o tema da representação é a cidade de São Paulo, esses rios estão ausentes.

A Lei de Terras, portanto, não determinou com clareza o que seria feito com a área remanescente, ou seja, essa área que,

“[...] embora pertencesse ao ancestral 'patrimônio do Conselho', não se enquadrava como "urbana" e, portanto, ao menos teoricamente, deveria ter na compra e venda os únicos instrumentos legais para sua alienação. Por outro lado, a própria noção de 'patrimônio do Conselho' não chegou a ser expressamente extinta pelo conjunto de leis que propunham a renovar os termos concernentes à propriedade fundiária no Brasil". (BRITO, 2007, p.51)

Essa foi a imprecisão na lei que fez, no caso de São Paulo, com que as áreas remanescentes do rocio passassem a ser, literalmente, terra de ninguém, estando submetidas ao jogo político e ao clientelismo, que caracterizaram esse período do século XIX na cidade. Dessa forma,

"[...] o poder de conceder parcelas de seu patrimônio, dispondo delas com significativa autonomia e, presumivelmente, valendo-se desse poder para favorecimentos pessoais característico de um sistema político de base clientelista pôde, assim, mesmo após a entrada em vigência da Lei de Terras, ser mantido pelas Câmaras Municipais". Isso teve um reflexo direto no processo de urbanização de São Paulo, uma vez que foram justamente as terras pertencentes a esses patrimônios que deram suporte à expansão da área arruada e à organização do mercado imobiliário urbano, num movimento que se associava ao processo de 
"modernização" ao qual aquela mesma lei se atrelava (BRITO, 2007, p.55).

Essa foi a base legal que permitia a acumulação baseada na expropriação do patrimônio comum e transformava a terra em mercadoria. Ainda que as águas não fossem mencionadas na lei, os rios também seriam afetados pela valorização das terras sob seu domínio.

Esse é o contexto específico da Lei de setembro de 1850 e alguns de seus desdobramentos. A origem das organizações municipais no Brasil, como foi visto, vem do período colonial, de 1603, data das Ordenações Filipinas, legislação que permaneceu em vigor mesmo após a Independência do Brasil.

Em 1828, com a reestruturação político-administrativa decorrente da Independência, o Governo Central realizou uma reforma na legislação que dizia respeito à organização municipal e ao gerenciamento de seu patrimônio territorial ${ }^{126}$. A partir de então, a venda, o aforamento ou a troca das terras pertencentes ao patrimônio do Conselho estavam vinculados à autorização dos presidentes de província, em uma clara tentativa de centralização do poder por parte do Governo Provincial.

Essa tentativa de centralização do poder passava pela obrigatoriedade da execução de um levantamento ou planta para a concessão dos arrendamentos cedidos pelos Conselhos. Planta essa que, no caso de São Paulo, jamais seria realizada, sendo objeto de disputas entre as ins-

126. O Regimento das Câmaras Municipais que se referia ao patrimônio do Conselho dispunha, entre outros, que: "Art. 420. - [As Câmaras Municipais] Não poderão vender, aforar ou trocar bens immóveis do Conselho sem autoridade do Presidente da Província em Conselho, enquanto não se installarem os Conselhos Geraes, e na Corte sem a do Ministro do Império, exprimindo os motivos e vantagens da alienação, aforamento ou troca, com a descripção topographica e avaliação por peritos dos bens que se pretendem alienar, aforar ou trocar. [...] Art. 430. - Obtida a faculdade, as vendas se farão sempre em leilão público e a quem mais der, excluídos os officiaes que servirem então as Câmaras, e aquelles que tiverem feito a proposta, e exigindo-se fianças idôneas, quando se fizerem a pagamentos, por não se poderem realizar logo a dinheiro, pena de responsabilidade pelo prejuízo d'ahi resultante. [...] Art. 440. - Da mesma forma e com as mesmas cautelas e responsabilidades prescritas no artigo antecedente, se farão os arrendamentos dos bens do Conselho; mas estes contractos poderão as Câmaras celebrar por deliberação sua, e serão confirmados pelos presidentes das Províncias em Conselho, e na Corte pelo Ministro do Império." Lei Imperial de 01/10/1828 In: Colleção das Leis do Império do Brasil, 1828, Parte Primeira. 
tâncias de governo, Municipal e Provincial. Sabia-se que, com ela, os favorecimentos pessoais obtidos através das concessões e arrendamentos tenderiam a acabar ${ }^{127}$.

Uma das justificativas da Câmara para a cobrança do foro nas concessões de terras do rocio era o aumento das arrecadações que incrementariam a receita municipal. A Câmara alegava que era necessária a obtenção dessa renda ${ }^{128}$ através de aforamento, e consequente alienação dos espaços de uso comum, para a realização de obras necessárias à cidade. É verdade que a situação econômica de São Paulo pouco mudara desde o fim do século XVIII, permanecendo isolada apesar do leve incremento da atividade comercial. No entanto, essa resposta da Câmara parece tentar esconder o fato de que a áreas remanescentes, que é o que estava em jogo nesse momento, eram muito extensas, não havendo interesse em preservá-las, mas sim, distribuí-las segundo seus interesses políticos e econômicos.

Interessante notar também que, mesmo antes de 1850, ou seja, antes de a terra adquirir legalmente o estatuto de mercadoria com a promulgação da Lei de Terras, os interesses sobre seu domínio já se manifestavam de uma forma muito evidente. A propriedade territorial passou a ter significado econômico antes da lei, do que se depreende que esta foi realmente apenas uma formalização de um processo que se iniciara muito antes. Esse movimento de acumulação a partir da propriedade da terra (e da água) também formava a classe dos proprietários de terra a

127. Para entender a relação da ausência de mapas desse período com a produção do espaço da cidade ver: GOUVÊA, José Paulo Neves. Cidade do Mapa: A Produção do Espaço de São Paulo através de suas Representações Cartográficas. São Paulo: Dissertação de Mestrado, FAUUSP, 2010.

128. Em 1830, o Presidente da província se recusou a submeter ao Conselho Geral da Província, uma proposta da Câmara paulistana que se referia à imposição de cobrança de foro nas concessões de terras do rocio. A Câmara insistia: "O terreno que ella [a Câmara] pede para repartir por meio de aforamento é todo aquelle que está dentro do rocio, não só da cidade como das freguezias do município, e mesmo aquelle, que a todo tempo ella puder reivindicar ou por que tenha cahido em commisso, ou por que seja possuído sem legítimo título. Daqui se infere não ser possível à Camara determinar ao certo a quantidade de terreno que se pretende aforar. [...] Todavia como seus réditos são assás diminutos, e de nenhuma sorte sufficientes para as obras públicas que tanto urgem [...], dirigiu agora uma proposta ao Conselho Geral para obter por esse meio algum algmento nas suas rendas [...]."Ata da Câmara Municipal de São Paulo, Sessão de 24/04/1830, p. 144 e Ofício de 30/04/1830 in: Registro Geral da Câmara da Cidade de São Paulo 1829-1830, p. 367 apud BRITO, 2007, p.83. 
partir da expropriação das terras antes consideradas bem comum.

Ainda em 1830, como o Governo Provincial havia negado a proposta, a Câmara, depois da aprovação da revisão das posturas municipais pelo Conselho Geral da Província, suspendeu a concessão gratuita de datas e solicitou ao fiscal da cidade, acompanhado do arruador, que executasse a demarcação das terras do rocio e elaborasse um plano. (BRITO, 2007, p.84), como se observa:

"Convindo para de futuro se evitarem as tortuosidades, que hoje se observam nas ruas dessa cidade e a falta de praças e de muitas outras servidões públicas, até de fontes e aguadas que se acham encravadas em prédios particulares com grande detrimento público, que antes de se concederem cartas de datas de terrenos no rocio desta cidade se proceda a uma demarcação designando-se ruas, e praças, e demais servidões públicas. [...] Semelhantemente considerando a Câmara que se acha a servidão do rio Tamanduatehy, que borda esta cidade com grande detrimento público; deliberou na dita sessão que Vossa Mercê proponha, fazendo os exames necessários e tentando todos os meios conciliatórios, as convenientes aberturas para a franqueza das precisas servidões. [...]."129

A Câmara tinha pleno conhecimento das necessidades da cidade e, em especial, sobre a condição do abastecimento de água e despejos que se agravaram muito nas primeiras décadas do século XIX, sendo que a falta de água era constante. O Tamanduateí tornara-se insalubre e suas margens, que naturalmente já eram suscetíveis ao aparecimento de lamaçais, tornou-se um local de acúmulo de detritos a partir dos despejos e das obras nele realizadas.

As terras de uso comum foram sendo apropriadas por particulares, a partir da divisão desse patrimônio em datas e favorecimento dos interesses políticos e econômicos da Câmara, da Província e de pessoas influentes desse período. As ações variavam de acordo com quem ocupava os cargos de comando dessas duas instâncias. O fato é que, dada a relação de interesses que se instituía, a delimitação e demarcação das terras de uso comum não interessava nem à Câmara nem ao Conselho Provincial.

129. Ata da Câmara Municipal de São Paulo, Sessão de 16/04/1830, p. 127 e Registro Geral da Câmara da Cidade de São Paulo 1829-1830, p. 259 apud BRITO, 200, p.83. 
Isso pode ser confirmado pela constatação de que simplesmente não havia registro cartográfico da cidade nesse período. Os que existem, mais escondem que revelam o progresso das concessões das terras de domínio comum. No mapa de 1844/47 (ver páginas 144-145), por exemplo, as áreas de uso comum aparecem, como vimos, de forma indiscriminada. Entretanto, esse documento prova que, na época, havia conhecimento técnico suficiente ${ }^{130}$ para a execução de uma planta circunstanciada do patrimônio municipal que discriminasse as terras sob domínio da Câmara daquelas que se pretendiam passar ao domínio privado.

Promulgada a Lei de Terras em 1850 e instituída a dúvida sobre o destino das áreas remanescentes do rocio, os interesses em questão tornam-se mais evidentes e as disputas se acirraram. Os frequentes conflitos entre as instâncias de governo se davam por conta de divergências na base dos governos. Mesmo assim, é possível notar que havia alguma identidade de interesses entre a Câmara Municipal e a Assembleia Legislativa Provincial na distribuição de datas, ainda que representassem interesses locais e provinciais.

Até 1852, depois da promulgação da Lei de Terras, estava proibida a cobrança de foro sobre as concessões realizadas pela Câmara Municipal e suspensas as concessões gratuitas de datas ${ }^{131}$. Assim, a Câmara Municipal de São Paulo enviou à Assembleia Legislativa Provincial uma

130. Esse mapa foi levantado sob a coordenação do engenheiro agrimensor Karl Abrahan Bresser, cuja própria presença em São Paulo nesse momento, é um reflexo de avanço na diversificação das atividades urbanas. Sabe-se que, além de Bresser, haviam outros profissionais agrimensores na cidade. Conforme a informação de Maria Lúcia Perrone Passos e Teresa Emídio (2009) o autor dessa planta, Karl Abrahan Bresser, era engenheiro agrimensor nascido na Prússia e que veio para o Brasil no ano de 1838 para trabalhar na construção de estradas e pontes no Governo da Província de São Paulo. Ainda segundo Passos e Emídio "era proprietário de uma chácara na região da atual rua Bresser, no Brás, e de uma fábrica de licores no Marco da Meia Légua. Autor de mapas de São Paulo, entre os quais o de 1841, é considerado o introdutor das primeiras plantas cadastrais na cidade." Eudes Campos (2008) continua, ainda sobre Bresser: "Assinou contrato por cinco anos com o Governo da Província de São Paulo, representado pelo major Bloem, em Bremen no dia $1^{\circ}$ de agosto de 1838 , e por esse documento percebe-se que, ainda que nele fosse qualificado como agrimensor, com diploma, sua responsabilidade no Brasil seria a de um verdadeiro engenheiro, pois deveria elaborar planos, fazer orçamentos e dirigir as obras da abertura de uma estrada de rodagem entre São Paulo e Santos".

131. SIMONI, Lúcia Noemia. O arruamento de terras e o processo de formação do espaço urbano no Município de São Paulo: 1840-1930. São Paulo, Tese de Doutorado FAUUSP, 2002. 
representação que propunha a venda dos lotes considerados adequados à edificação urbana e ao aforamento dos "terrenos do subúrbio" com a intenção de aumentar os rendimentos municipais. ${ }^{132}$

A proposta foi aprovada pela Assembleia Legislativa Provincial, autorizando a venda de terrenos e o aforamento de chácaras, alterando a cobrança do foro anual de 100 para apenas 1 real por braça (SIMONI, 2002). Imediatamente após esse ato, o Presidente da Província suspendeu a autorização alegando que não haveria tal concessão sem que fossem realizados

“[...] certos trabalhos preparatórios por meio dos quaes fique com clareza averiguado: $-1^{\circ}$ quaes os terrenos pertencentes inquestionavelmente ao rocio da Capital e Freguezias que estão devolutos. $-2^{\circ}$ quaes os que deveriam ser reservados para logradouro público. $-3^{\circ}$ quaes os que cumpre reservar para a abertura de ruas e praças, para cemitérios das povoações, e outras edificações públicas, quer no presente, quer no futuro, ordena aos Snres. Presidente e vereadores da mesma Câmara Municipal q. não [...] aforem antes de apresentarem ao governo um mapa onde se especifiquem as circunstancias acima expos$\operatorname{tas}[\ldots]]^{\prime \prime 33}$

Apesar de esta Portaria suspender os aforamentos das terras comuns, enquanto não fossem realizados os levantamentos e a planta citados, a concessão gratuita de terras do rocio permaneceu autorizada, conforme a lei aprovada pela Assembleia Legislativa Provincial, somente sendo suspensa dois anos mais tarde, quando a regulamentação da Lei de Terras, de 1854, reiterou a obrigatoriedade da realização de um levantamento da

132. "Além disso, na mesma representação, alegava que, em virtude das concessões terem sido limitadas a uma data por indivíduo e do estabelecimento de dimensões máximas bastante reduzidas, de 10 braças de frente, impostas em 1830 , havia se tornado comum a prática de, para a formação de uma chácara, um indivíduo, em nome alheio, proceder a vários pedidos de datas, adquirindo-as posteriormente por compra. Por isto, solicitava também autorização para concessões, por aforamento, de datas de maiores dimensões, com até 100 braças em quadra (c. 48.40om2), limitadas a uma data por indivíduo, pela qual seria pago o foro anual de 100 réis por braça, além de um imposto proporcional à superfície concedida, para as despesas com medição e demarcação do terreno." (BRITO, 2007, p.86)

133. Portaria do Exmo. Govo. Proval. de 29 de outubro de 1852 apud. BRITO, 2007, p.87. 
situação de todas as terras municipais. Isso permitiu que continuasse a alienação do patrimônio municipal sem a prévia realização de sua discriminação, demarcação e reserva das terras, praticamente legalizando o descontrole sobre essas terras.

A Câmara chegou a iniciar o levantamento e as medições do rocio. Entretanto, o engenheiro provincial destacado para essa tarefa não concluiu os trabalhos ${ }^{134}$, já que havia manifestado interesse na manutenção do regime de distribuição de terras.

Em 1859, uma Portaria emitida pelo Presidente da Província revogou a decisão de proibição das concessões, respondendo a uma solicitação da Câmara para "repartir a terra gratuitamente pelo povo", apelando para a Carta de Doação do rocio, de 1598. A Câmara argumentou ainda que a iminente chegada da estrada de ferro certamente provocaria o crescimento da cidade e a posterior demanda por novas edificações. Solicitava-se, então, a autorização para a retomada das concessões gratuitas de terras e a ampliação dos limites do rocio.

A alegação da Câmara, ao reivindicar as terras para "reparti-la com o povo", não é coerente com os fatos. Era evidente que a cidade e sua população aumentariam muito nos anos seguintes, em decorrência do aumento do volume de negócios e imigração. Assim, as elites pressionavam a Câmara para que intensificasse a distribuição de datas. A distribuição de datas era injusta e discriminatória, resultando na concentração da propriedade de datas. Até o fim do Império foram frequentes os casos de apropriação indébita de terras devolutas e de uso comum. Todos previam que a cidade passaria por um acentuado processo de crescimento populacional e urbanização, decorrentes do fim da escravidão e início da

134. A Câmara solicitou ao Governo Provincial um engenheiro para realizar o levantamento sendo que, para isso, foi indicado o engenheiro provincial José Porfírio de Lima. Em 1858, a Câmara alega que o engenheiro "abandonou esse trabalho logo depois de começado" (BRITO, 2007, p.89-90). Nessa época a Câmara já contava com um engenheiro em seus quadros (CAMPOS, 1997) mas os vereadores alegaram que esse profissional estaria impossibilitado de proceder aos levantamentos exigidos já que, para isso, teria que ser afastado de suas atribuições (SIMONI, 2002). Segundo Mônica Silveira Brito, Porfírio pertencia aos grupos interessados em manter o atual regime de distribuição de datas, já "que se tornou vereador na década de 1860 e membro da Comissão Permanente de Datas, esteve intimamente relacionado a diversas outras obras voltadas aos melhoramentos urbanos. Atuava também como fiscal de obras empreitadas pela administração provincial junto a particulares. Nessa função, notabilizou-se pela postura tendenciosa de seus pareceres técnicos, protegendo os interesses dos contratados em detrimento dos públicos." (BRITO, 2007, p.89 nota 45) 
imigração, fazendo com que se configurasse uma intensa especulação fundiária na cidade. Isso pode ser facilmente identificado na documentação escrita do período, mas praticamente inexiste na documentação cartográfica de São Paulo ${ }^{135}$.

Prevaleceram, portanto, direitos estabelecidos no século XVI, em detrimento das normas recém instituídas. $O$ próprio movimento de pretensa modernização, que então se iniciava, mantinha em evidência os arranjos institucionais e as práticas de caráter arcaico estabelecidos séculos antes. (BRITO, 2007)

A Portaria de 1859, que autorizou a retomada das concessões gratuitas de terras do rocio, tornou-se especialmente importante pelo fato de que, logo depois de sua publicação, ocorreu farta distribuição de datas na região do patrimônio do Conselho, sendo considerada um surto de datas. Foram distribuídas, em um ano, cerca de 36\% do total de datas concedidas em quase todo o século. ${ }^{136}$

A indefinição era um fato constituído pelas leis, portarias e avisos. Em 1859, uma circular obrigava a Câmara a informar ao delegado do Diretor Geral de Terras Públicas ${ }^{137}$ o limite do rocio e dos campos de uso comum obtendo como resposta que estas eram "as terras dentro dos limites da meia légua concedidas por Martim Affonso" (BRITO, 2007). À Repartição Geral de Terras Públicas, cabia o controle das terras devolutas situadas fora dos limites dos rocios, devendo autorizar a venda de terras para agricultura e criação. Ironicamente, a Repartição foi informada pela Câmara paulistana que as localidades em questão eram logradouros de uso comum dos moradores, conseguindo, a Câmara, fazer com que todas as solicitações de compra de terras nessa região passassem por sua prévia aprovação. (BRITO, 2007)

"Estava em andamento um processo de apropriação privada dos campos de uso comum, ou logradouros públicos, do Municí-

135. CAMPOS, Eudes. São Paulo Antigo: Plantas da Cidade. Informativo Arquivo Histórico Municipal, 4 (20): set/out. 2008. Sobre a ausência desses mapas ver também GOUVÊA (2010).

136. Segundo Roberto Mônaco, "em 1860 foram distribuídas 476 do total de 1300 datas concedidas em São Paulo entre os anos de 1801 e 1891". MÔNACO, Roberto. As terras devolutas e o crescimento da cidade de São Paulo. Dissertação de Mestrado FAUUSP, São Paulo, 1991.

137. "O Delegado do Diretor Geral de Terras Públicas nessa ocasião era o também vereador Antônio José Barbosa da Veiga que integrava a "Comissão Permanente de Datas" da Câmara"." (BRITO, 2007, p.91 nota 52) 
pio de São Paulo.[...] o conflito em pauta era em torno da forma de aquisição das terras, onerosa ou gratuita, e a quem caberia reparti-las - Câmara ou Província. Estes interesses contrapunham-se diretamente ao direito dos usuários dos logradouros, que efetivamente se utilizavam das terras para subsistência [...]. (SIMONI, 2002, p.59)

Diante dos impasses em torno da distribuição das terras do rocio, mais uma vez, em 1861, a administração provincial solicita à Câmara que encarregue um engenheiro para realizar os tais trabalhos precisos de levantamento. A Câmara não somente se opunha à demarcação das terras do rocio como também não conseguia realizar os registros das terras que indubitavelmente lhe pertenciam, como era o caso das terras situadas fora da área considerada urbana ${ }^{138}$. Havia, portanto, certa incapacidade administrativa, ou mesmo desprezo, sobre as terras de domínio comum. O mesmo se aplicava aos rios da cidade que, inclusos ou não nos limites do rocio, permaneciam sem nenhuma ou poucas referências oficiais. Não por acaso, os rios da cidade não aparecem nos debates sobre a distribuição de datas. Ainda que fosse a falta de água a principal preocupação dos moradores de São Paulo nesse período, era a terra que aparecia como principal interesse nas disputas.

$\mathrm{Na}$ década de 1860 , a cidade continuava a ser abastecida por chafarizes a partir da captação de água, principalmente nas nascentes do Anhangabaú, que, reservada no tanque de Santa Teresa, era aduzida até a caixa d'água da Cruz Preta. A água dos chafarizes da cidade não eram suficientes para abastecer toda a população, sendo necessário retirar água de cisternas abertas nas margens do Tamanduateí e do Lavapés. Continuava a coleta de água diretamente dos rios, além da venda pelos aguadeiros. (FREITAS, 1985)

Nos anos de 1862 e 1863, durante a gestão do Presidente de Província Vicente Pires da Motta, a Repartição Geral de Terras Públicas decidiu realizar, ela mesma, os trabalhos de discriminação dos domínios dessas terras, mas foi impedida diante da recusa da Câmara em autorizar

138. "Lembremos que não foi apenas quanto à talvez complicada tarefa de confecção de uma planta que as autoridades se omitiram, pois nem mesmo o registro dos terrenos indubitavelmente pertencentes ao Conselho e situados para além da área urbana, imposto pelo Aviso de 17/01/1855, que complementava as determinações do artigo 910 do Decreto 1318, chegou a ser efetivado." (BRITO, 2007, p.90 nota 49) 
a utilização dos Livros de Registro de Cartas de Datas, sem as quais o trabalho foi inviabilizado. (BRITO, 2007)

Nos anos de 1866 e 1867, São Paulo passava por "uma das maiores secas de que há memória" (FREITAS, 1985). A falta de chuvas se aliava à precariedade do sistema de distribuição de água. Ainda assim, a Guerra do Paraguai absorvia as atenções do Presidente da Província, mais preocupado com a representação paulista nessa disputa, enquanto a municipalidade se ocupava da distribuição de terras e cessava a distribuição de água. Dessa forma, todos os chafarizes da cidade secaram, ficando os aguadeiros responsáveis pelo abastecimento de água de São Paulo.

Com relação aos trabalhos de discriminação entre domínios de terra municipais e privados, em 1868, a Administração Provincial, através da Repartição Geral de Terras Públicas, realizou o tombamento dos Próprios Nacionaes do município de São Paulo, sem realizar, no entanto, nem medição ou demarcação, nem a discriminação entre domínios particulares e municipais. Foi somente em 1886 que esse trabalho foi parcialmente realizado pelo Governo Provincial (MÔNACO, 1991) ${ }^{139}$.

Em 1875 foi aprovado o Código de Posturas ${ }^{140}$, que vinha sendo redigido desde a década de 1860 . O código de 1875 mantém as Cartas de Data como "contrato perpétuo e passível de transmissão por herança, doação, arrendamento, aforamento e venda". (SIMONI, 2002, p.95) Além disso, esse código representou uma tentativa de ampliar o controle sobre as atividades relativas aos rios e as várzeas, limitando as atividades de subsistência especialmente nas áreas de domínio comum. Dessa forma, o código determinava que era "prohibido lançarem-se materias excrementicias nas ruas, largos, pateos e em logares proximos ás fontes e vertentes, ou conservarem-se cloacas junto às mesmas; sob pena de $10 \$$ de multa." Mantinha-se a secular tentativa de se preservar os rios proibindo "empregar-se na pesca qualquer substancia ou veneno que possa ser prejudicial à saude publica; sob pena de 30 \$ de multa." Também limitava-se a caça ao proibir "caçar com armas de fogo na Cidade e seus arredores, sob pena de $30 \$$ de multa" " "vender, consertar ou emprestar armas offensivas a escravos." Ainda atacava os banhos de rio ao determinar que "ninguem poderá lavar-se de dia nos rios em lugares publicos.

139. Na década de 1920 outro trabalho de tombamento e discriminação do patrimônio municipal foi realizado pelo Governo Estadual (SIMONI, 2002, p.79).

140. Câmara Municipal de São Paulo, Código de Posturas da Câmara Municipal da Imperial Cidade de S. Paulo, 1875. 
O infractor soffrerá a multa de 10 ou 24 horas de prisão. [...] A lavagem em rios só será permitida quando a pessoa estiver vestida, de modo que não offenda a moral publica."

O código ainda determinava que

"[...] toda a pessoa de qualquer sexo ou idade que fôr encontrada sem occupação e em estado de vagabundagem, será mandada apresentar a auctoridade policial competente, para assignar o termo de que trata o Codigo do Processo Criminal. Os menores serão pela primeira vez levados a seus paes ou tutores, e na reincidencia serão conduzidos á presença do Juiz de Orphams, afim de providenciar na fórma da Lei. [...] E' prohibido, sem licença da Camara, tirar-se esmolas no Municipio para qualquer fim. Os infractores soffrerão a multa de 10 \$ e dous dias de prisão. [...] E' prohibido aos escravos valetudinarios ou não, esmolarem para subsistencia sua ou por ordem de alguem. Os que forem encontrados, serão apresentados ao Juizo de Orphams, que providenciará corno fôr de direito."

Essas determinações, presentes no código de 1875, instituíam o controle sobre os rios e o uso dos rios, limitando as atividades da pesca, caça e navegação. $\mathrm{O}$ contexto em que se insere o código, ao reforçar a distribuição de terras através das datas, alinhando-se aos interesses políticos e econômicos das elites, faz com que a limitação dos usos do rio como fonte de subsistência e a punição aos "desocupados", possa ser relacionada às transformações relativas à substituição do trabalho cativo pelo trabalho livre, funcionando também como uma forma de sujeição do trabalho ao capital. Isso acontecia na cidade no momento em que o capital era acumulado a partir da propriedade da terra e o trabalho livre se instituía através da importação de mão de obra. Passava a ser importante controlar os rios e as atividades neles realizadas como também evitar a subsistência a partir desses recursos, ainda que já estivessem bastante sujos.

As décadas de 1870 e 1880 foram marcadas pela distribuição de datas pela Câmara no rocio e na marca das seis léguas ${ }^{141}$, com caracte-

141. "Aliás, segundo SIMONI (2002), a despeito das determinações do Código de Posturas, naquele momento (1875-1878) estavam sendo distribuídas, gratuitamente, terras municipais que se encontravam ainda disponíveis no Morro do Caaguassú, Telégrafo, Brás, Pary, Estrada do Vergueiro, Várzea da Moóca, Cam- 
rísticas muito próximas da venda, mas com uma cláusula de caducidade caso não houvesse indícios de construção após seis meses da concessão (BRITO, 2007, p.97). Isso vinculou a manutenção da data aos proprietários com recursos financeiros, condição que poucos na cidade mantinham. Dessa forma, a acumulação, que acontecia através da propriedade da terra, também passava a acontecer através da instalação de infraestruturas.

"[...] aqueles que, em período imediatamente anterior, tinham sido agraciados com o privilégio de obter terras do patrimônio público, muitas delas por concessão gratuita, puderam extrair, pouco depois, uma renda bastante elevada, uma vez que naquele intervalo a cidade crescia rapidamente, com uma enorme intensificação do mercado imobiliário, lançamento de loteamentos e instalação de infra-estrutura urbana." (BRITO, 2007, p.98)

O processo de dissolução e expropriação desse bem comum, que, como vimos, eram as terras do rocio, aconteceram de diversas formas, quase desaparecendo. O texto do código de 1875, em suas disposições para concessão de datas, já não faze mais menção a expressões coloniais como rocio e bens do Conselho, passando essas terras a serem designadas patrimônio municipal. (BRITO, 2007)

O código de 1875 é o marco institucional da passagem do que vinha sendo entendido como bem comum e que passa, a partir de então, a ser considerado propriedade. É importante salientar que isso acontece no momento em que as terras de domínio comum sofreram um intenso processo de privatização. De bem comum, esses domínios passaram a patrimônio do Conselho e, a partir deste momento, serão considerados um bem municipal. Isso significa que as terras sob essa designação passavam a ser consideradas, então, uma propriedade privada, ainda que uma propriedade privada do município.

Vale pontuar aqui que o Brasil ainda estava sob o Império embora a proclamação da República estivesse próxima. Portanto, todas as terras a que vimos nos referindo estavam sob o domínio do Imperador, sendo por ele concedidas. Não havia ainda, portanto, o conceito do bem público, que seria instituído na República.

Esses momentos foram seguidos pela instalação de um vigoroso

po Redondo, Estrada do Lavapés e Caminho da Penha. (BRITO, 2007, p.98) 
mercado de aluguéis na cidade de São Paulo. Em 1886, 70\% dos imóveis paulistanos chegaram a estar alugados, segundo o Relatório da Comissão Central de Estatística. O início da década de 1880 também foi marcado por uma forte valorização das datas de terra.

Foi também nesse período que, a partir da instalação de infraestruturas urbanas, começaram a ser explorados comercialmente alguns serviços públicos, como esgoto e distribuição de água, empreendido pela Companhia Cantareira de Águas e Esgotos. A infraestrutura urbana, mesmo quando empreendida pelo poder municipal, também passava a ser considerada uma propriedade do município.

Com relação à quase extinção das terras sob o domínio do município, é possível afirmar que a parcela mais significativa do atual patrimônio municipal teria passado a mãos privadas em momento anterior. Os primeiros anos da década de 1850 constituíram momento importante nesse processo, quando a Câmara procedeu o aforamento de muitas chácaras, diversas com até "10o braças em quadra". (BRITO, 2007)

Os últimos anos do Império foram caracterizados por uma forte presença do Governo Provincial, a partir da instituição, em 1886, da Comissão Especial de Colonização, cujo objetivo era propiciar a ampliação dos núcleos coloniais existentes para aumentar o número de imigrantes neles assentados. Com grande parte das terras próximas da capital nas mãos de particulares, essa Comissão promoveu a medição e a demarcação das terras devolutas de São Paulo. ${ }^{142}$ Dessa forma, o Governo Provincial obteve o controle administrativo dessas terras, devendo aplicá-lo à colonização ou venda, previamente medidas e demarcadas. No momento em que se regularizava a situação das concessões e as terras de uso comum passam a ter dono, não haveria mais motivo para que não existissem mapas que representassem todas as terras que circundavam o núcleo urbanizado. Mapas, a partir de então, passariam a ser produzidos com o objetivo de, justamente, legitimar o processo de transferência de terras do antigo patrimônio do Conselho do domínio comum ao particular. Isso pode ser visto no mapa das páginas 150-151, que representa a cidade no primeiro ano do século XX.

142. "Segundo nos informa Roberto Mônaco (1991), esses levantamentos auferiam ao rocio de São Paulo um perímetro de $28.327,20 m$ e uma área de $43.560 .000 \mathrm{~m}^{2}$." Essa área corresponde a um raio de aproximadamente 3.740m. (BRITO, 2007, p.100) 
Com o estabelecimento das primeiras ferrovias de São Paulo ${ }^{143}$, as várzeas próximas à colina sofreram transformações consideráveis, principalmente as várzeas dos rios Tamanduateí e Tietê, que receberam, respectivamente, a Estrada de Ferro Santos a Jundiaí, em 1867, e a Estrada de Ferro Sorocabana, em 1870 . Os vínculos que a cidade tinha com as suas várzeas acabaram por ser alterados pela ferrovia, já que o transporte de pessoas e mercadorias passaram a ser menos utilizados nos rios, como no caso de locais como Barra Funda, Água Branca e Lapa. (SANT'ANNA. 2007, p. 262)

Após a alienação das terras do antigo rocio, já durante a República, a legislação tratava de legitimar as propriedades e proibir atividades nas áreas que agora tinham legítimos proprietários. Note-se que a lei já se refere aqui ao patrimônio municipal como um local público. A lei municipal $n^{\circ} 68$ de 13 de novembro de $1893^{144}$ dizia que

"E' absolutamente prohibida a entrada em terrenos alheios, abertos ou fechados, sem consentimento de seus donos, para exercicio da caça; o infractor incorrerá na multa de 50\$000, e, no caso de reincidencia, a mesma multa de 50\$000, e mais cinco dias de prisão. [...] O exercicio de caça nos logares publicos ou servidões municipais, só terá logar 500 metros distante dos povoados; o infractor incorrerá na multa de 20\$000.[...] Para o exercicio da caça nos logares publicos todo o caçador tirará licença annualmente na Intendencia Municipal, pagando o imposto de $10 \$ 000$, e bem assim os vendedores ambulantes de caça, salvo se houver outro nas tabellas de impostos municipaes, que, nesse caso, é o que ceve prevalecer. $\mathrm{O}$ imfractor que for encontrado sem licença pagará a multa de $30 \$ 000$, pela

143. Também chamada de Estrada de Ferro Santos a Jundiahy, a ferrovia da The São Paulo Railway Company Ltd., "iniciada em 1860 e inaugurada sete anos mais tarde,[...] aproximava-se da Capital pela Várzea do Tamanduateí, a sudeste, atravessava a área habitada, ao norte, invadindo uma parte do Jardim da Luz, e se dirigia a noroeste em direção a Jundiaí" (CAMPOS, 2008). A Estrada de Ferro Sorocabana foi inaugurada em 1870, inicialmente para escoar a produção de algodão do interior paulista e posteriormente estendeu seus serviços à crescente demanda da produção cafeeira. A Estrada de Ferro São Paulo a Rio de Janeiro começou a funcionar na cidade em 1875, com a intenção de escoar a produção de café do Vale do Paraíba e interligar São Paulo e Rio de Janeiro através da Estrada de Ferro D. Pedro II que vinha do Rio e chegava até Cachoeira, atual Cachoeira Paulista.

144. Câmara Municipal de São Paulo, Lei no 68 de 13 de novembro de 1893. 
primeira vez, de $50 \$ 000$ pelas demais, e 5 dias de prisão."

A lei ainda protegia as condições biológicas de reprodução dos animais, como forma de garantir a caça:

“E' absolutamente prohibida a caça de perdizes e codornas, como a destruição de seus ninhos e ovos, de 10 de setembro a 10 de abril, por ser reconhecidamente o tempo de sua procreação, e bem assim fica absolutamente prohibida, a contar de 10 de outubro a 10 de abril, a venda pelas ruas e mercados, de passaros de quaesquer especies, mortos ou caçados, com o fim de negócio. O infracto incorrerá na multa de $30 \$ 000$ pela primeira vez, de mais 50\$000 nas demais, e 5 dias de prisão."

Com a mesma intenção de preservação da pesca, a lei de 1893 ainda determinava que

"Será livremente permitida a pesca nos rios Tieté e outros do Município, porém, as redes de pesca terão as malhas com o tamanho minimo de quarenta milimetros por malha. As que forem encontradas sem este padrão serão aprehendidas, $e$ aquelles que com ellas forem encontrados no exercicio da pesca, serão multados em $10 \$ 000$ da primeira vez, e no dobro nas reincidencias. [...] E' absolutamente prohibido o emprego da dynamite, raiz de timbó e outras drogas venenosas para a pescaria e matança de peixe. $O$ infractor incorrerá na multa de cincoenta mil réis, e cinco dias de prisão, além de outras penas de damno que resultarem a terceiros, da applicação dessas materias nos rios."

Ao mesmo tempo, defendia as propriedades que, nitidamente fizeram parte das antigas terras de domínio comum expropriadas durante o século XIX.

"No exercicio da pesca em rios publicos, não podem os pescadores fazer abicar suas canôas ou embarcações nas margens e nem entrar nos terrenos particulares, fazendo nestes estragos ou damnos. O infractor incorrerá na multa de $30 \$ 000$, e 2 dias de prisão por vez que o fizer, além d'outras penas em que possa incorrer." 
A navegação também foi objeto da lei, sendo regulamentada ${ }^{145}$.

"As lanchas, botes e canôas que se empregarem no trabalho de carregação de areia, lenha, tijolos, telhas e outros misteres de negocios, serão numeradas por placas, pagando de cada uma $6 \$ 000$ as lanchas e botes, e $3 \$ 000$ as canôas. Os que forem encontrados sem numeração, serão aprehendidos até o pagamento do imposto e com a multa de $20 \$ 000$ de cada um."

Pelo texto da lei é possível entender que os rios e as águas continuavam a ser considerados um bem comum ainda que esse bem não se manifestasse mais como um patrimônio comum. As águas do rio permaneciam públicas, enquanto as terras do rio eram privatizadas.

É clara a intenção da lei de proteger as áreas de caça e os rios como uma fonte de subsistência. Isso se observa nos casos de preservação das perdizes e codornas nos períodos de reprodução, na proibição da utilização de redes nos rios bem como o uso de venenos e explosivos, preservando, assim, a reprodução e futuro desenvolvimento dos animais. Por outro lado, a própria regulação e controle do acesso às áreas de caça e aos rios, além da cobrança de tributos e impostos, é uma forma de controlar o acesso de uma parcela dos moradores a esses bens, agora praticamente limitado ao canal dos rios. Considerando que muitas áreas de domínio comum, nesse momento, após distribuição de muitas datas, estavam sob domínio particular, é possível acreditar que as determinações dessa lei tinham a intenção de assegurar e reforçar a validade dessas propriedades.

145. Nesse mesmo período, por volta de 1880, a legislação tratava de atacar os banhos de rio por considerá-los uma prática inconveniente aos "bons modos". Segundo Affonso A. de Freitas a "proibição por se tratar de hábitos ancestrais, legados dos antepassados guaianás, carijós e murumimis, avoengos em duas quintas partes do povo paulistano? Por uma simples questão de tecnologia talvez?... Verdadeiramente deselegante, chato, vulgar, de mau gosto poderia parecer dizer-se - Nadar, tomar banho, jogar peteca, petequear como se dizia, em vez de se recorrer à erudição cosmopolita dos - sports, rowing, foot qualquer cousa inegavelmente menos rebarbativa... Foi no tempo dos urbanos, espécie de guarda cívica, então comandados por um veterano do Paraguai, major Manoel Vieira, por antonomásia o Manequinho alfaiate. A proibição era concretizada em formidáveis pegas á saparia por aqueles mantenedores da ordem que, incutindo a desordem entre os banhistas, cercavam as duas margens do Tamanduateí, no trecho da rua Glicério, ao tempo do Conde d'Eu." (FREITAS, 1985, p.67) 
A planta conhecida como "Mapa das Chácaras" de São Paulo ${ }^{146}$ - ver páginas 152-153 - representa, como o seu título indica, as propriedades de terra referentes a "chácaras, sítios e fazendas ao redor do centro", "desaparecidas com o crescer da cidade". Esse mapa mostra os limites das propriedades dessas chácaras e o nome do proprietário. Ele foi confeccionado com base em documentos cartoriais que informam que em um ano específico, determinadas terras pertenciam a um certo proprietário. Dessa forma, esse mapa não mostra os anos em que essas terras foram alienadas, apenas garante que naquele ano grafado aquele era o proprietário. Além dos limites de propriedade das chácaras, esse mapa apresenta as estradas de conexão históricas internas e entre outros núcleos urbanos, os rios e córregos. Apesar de esse mapa não ter uma data, pela forma do rio Tamanduaté, já canalizado próximo a colina, e pelos anos grafados, é possível afirmar que representa a situação das chácaras e propriedades principalmente da segunda metade do século XIX e começo do XX.

O mapa das chácaras revela o que a Câmara e os mapas da cidade desse período foram incapazes de registrar, isto é, a acumulação a partir da expropriação das terras e águas de uso comum, uma vez que o antigo rocio já aparece totalmente repartido em propriedades. Essa fragmentação e homogenização do espaço, ao contrário dos espaços de uso comum, permaneceriam no espaço e estruturariam o arruamento da cidade a partir do loteamento das chácaras. Ainda que o núcleo urbanizado permanecesse contido no triângulo no final do século XIX, já eram claros

146. Tivemos acesso a uma cópia manuscrita, parte do acervo do Museu Paulista, que contém o seguinte registro no verso: "o presente mapa foi organizado pelo eng ${ }^{\circ}$ Gastão Cezar Brirrembach de Lima para a exposição do IV Centenário de S. Paulo, apoiado nos documentos do arquivo Aguirra". Profundo conhecedor de questões de propriedade imobiliária da capital e no Estado de São Paulo, João Batista de Campos Aguirra, nascido em 1871 em Limeira, São Paulo, era conhecido pela atividade comercial e arquivística. Foi proprietário do chamado de Arquivo Aguirra. Também proprietário de terras ao sul da capital, Aguirra publicou estudos sobre a questão das terras e seus proprietários, sobretudo em São Paulo. Levantou diversas falsificações relativas à propriedade fundiária em São Paulo no início do século XX. Atualmente, o Arquivo Aguirra faz parte do acervo do Museu Paulista da Universidade de São Paulo. PIRES, Walter. Arquivo Aguirra. Fonte documental sobre a formação territorial de São Paulo. in Anais do Museu Paulista. São Paulo. 10/11 p.61-78, 2002. 
os fundamentos da urbanização, da produção do espaço e da incorporação da natureza da cidade contemporânea.

O mapa das páginas $154-155^{147}$ torna evidente a relação dessas propriedades com as estradas e, principalmente, com os rios e córregos. A sobreposição do perímetro de 3.300 metros do rocio revela que as ancestrais terras de uso comum simplesmente não implicaram qualquer permanência ou evidência de estruturas espaciais que permanecessem após a distribuição de datas. Esses espaços são ignorados pelas divisas das chácaras. Também é possível observar que os limites das propriedades geralmente são definidos pelas estradas e caminhos e também pelos rios e córregos. Sobre a relação dos limites de propriedades e os rios, percebe-se que apenas o leito menor ${ }^{148}$ é considerado. Portanto, as várzeas e planícies aluviais, do ponto de vista da propriedade territorial, já eram consideradas terra ocupável. Assim, essa parte dos rios, o leito maior, já se constituíam como mercadoria.

147. O Mapa das Chácaras foi redesenhado durante essa pesquisa. As informações textuais foram transformadas em códigos numéricos, evidenciando a relação dos rios e estradas e caminhos com as propriedades de terra.

148. O arquiteto Alexandre Delijaicov, em palestra proferida no Arquivo Público do Estado no dia 20 de março de 2014, defendeu que o rio e suas várzeas, em São Paulo, passassem a ser chamados de leito menor e leito maior. 

Anno de

1842

CARTA

DA CAPITAL DE

SÃO PAULO

O Exmo. Srn. Barão de Caxias mandou executar pelo Engenheiro da Columna José Jacques da Costa Ourique Fortificador da

Capital

1842

Ourique, José Jacques da Costa

Escala Gráfica em braças (1:6.000)

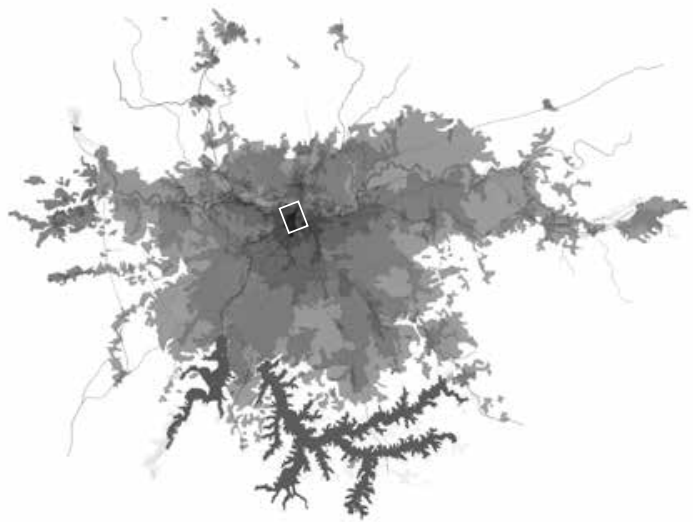

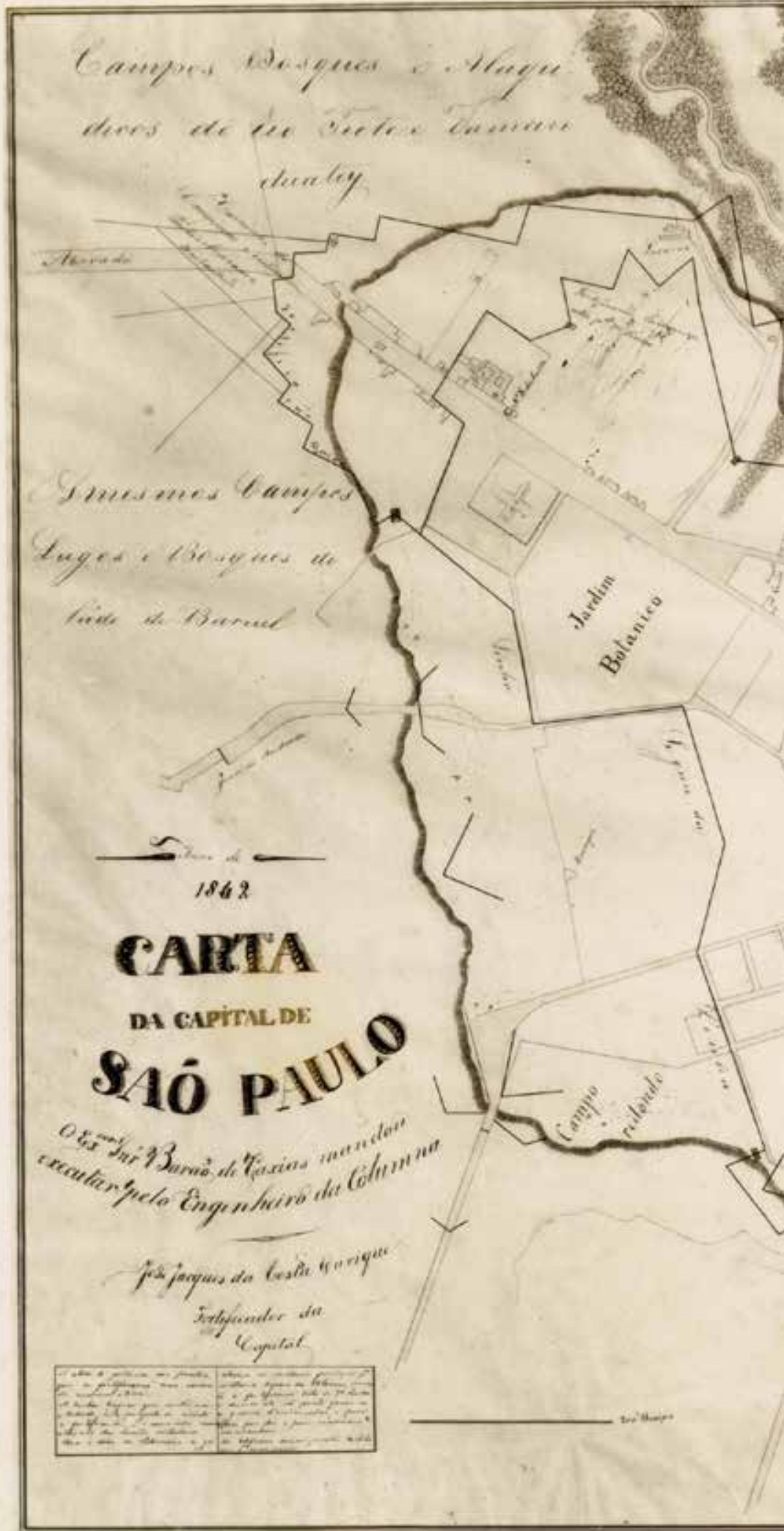


MAPPA

DA

CIDADE de SÃO PAULO

offerecido

A SUA MAGESTADE O IMPERADOR

pelo Prezidente da provincia

Manoel da Fonseca Lima e Silva

Feito pelo Engo Civil

C.A. Bresser

$1844 / 1847$

Bresser, Karl Abrahan

Escala Gráfica em palmos (1:6.000)

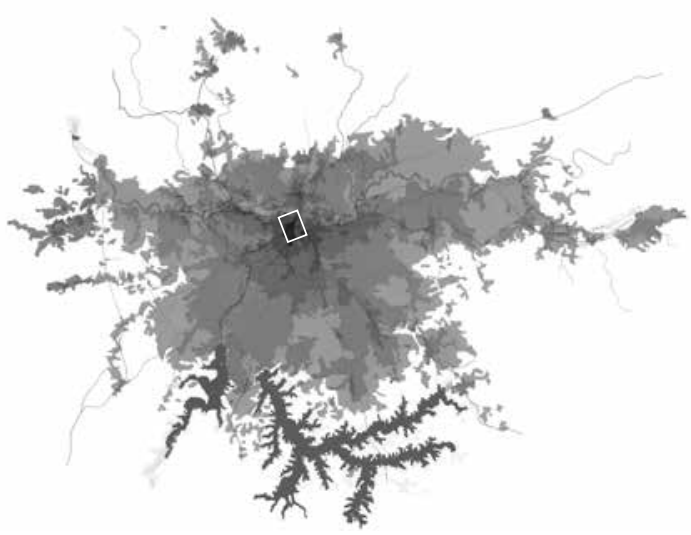

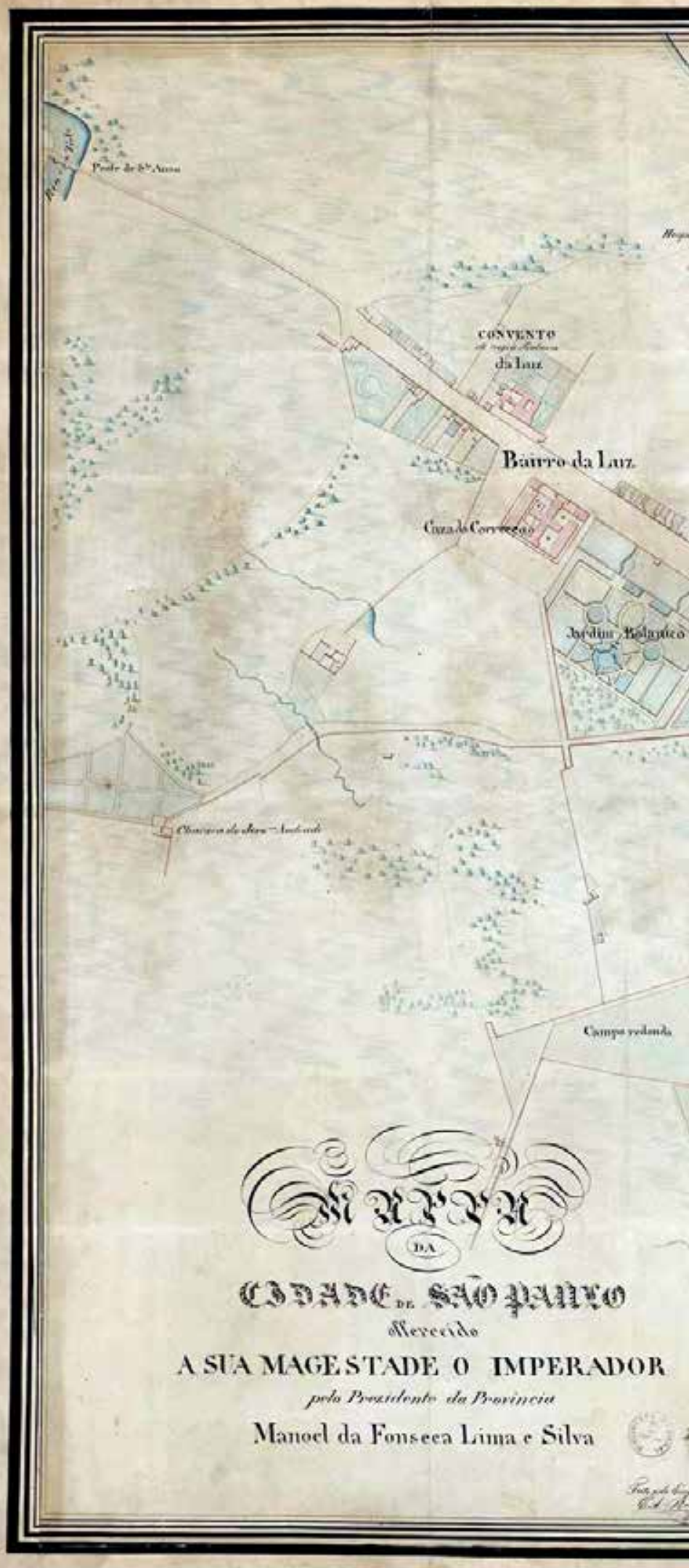




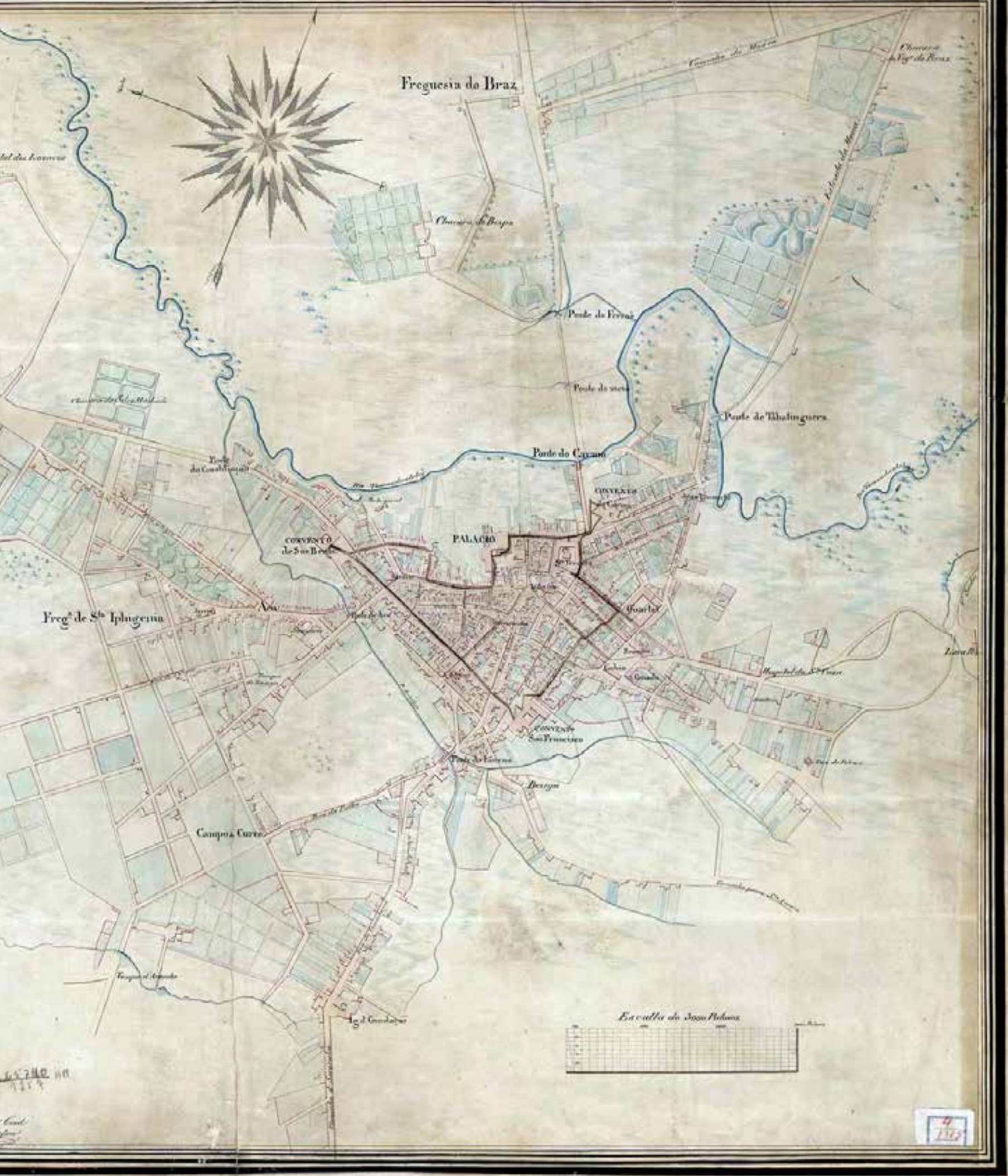


PLANTA DA CIDADE DE SÃO PAULO

Levantada pela

COMPANHIA CANTAREIRA E ESGOTOS

HENRY B. JOYNER M.I.C.E.

ENGENHEIRO EM CHEFE

1881

1881

Companhia Cantareira e Esgotos

gráfica (1:5.000)

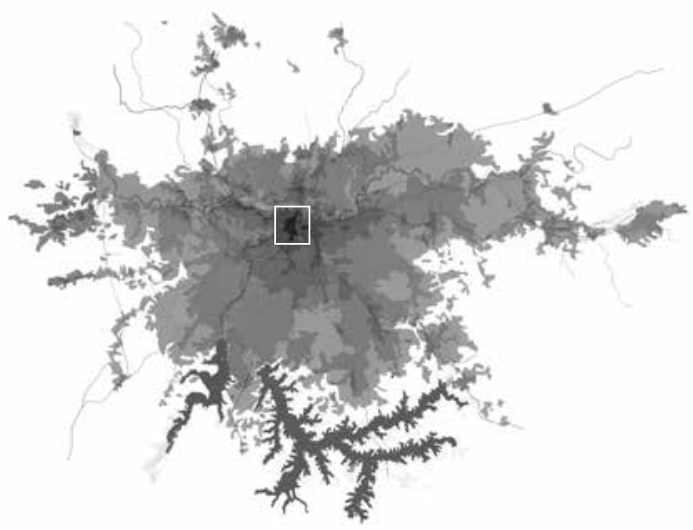




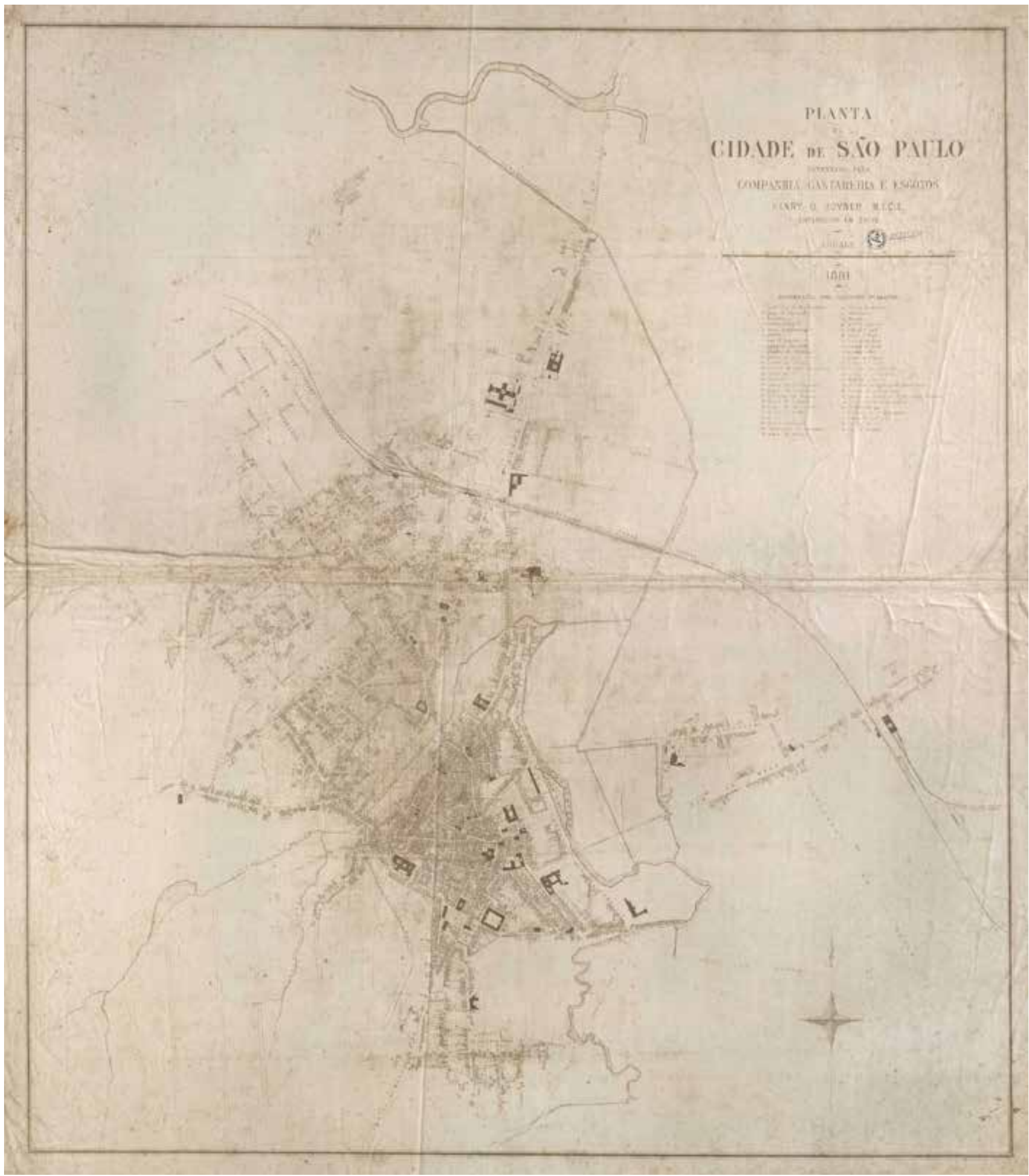


PLANTA

DA CIDADE

DE

SÃO PAULO

organisada

para o

ALMANAK DE S. PAULO DE 1883(4)

publicado por

Jorge Seckler \& $C^{\text {ia }}$

ESCALA 1:10.000

1883(4)

Seckler, Jorge

1:10.000

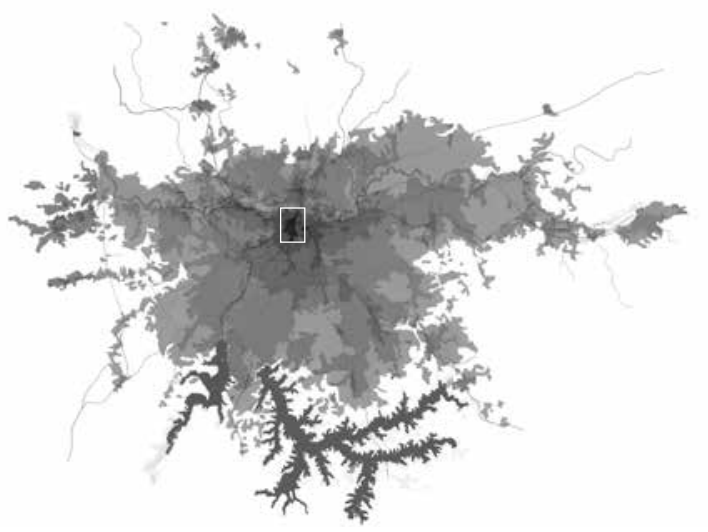

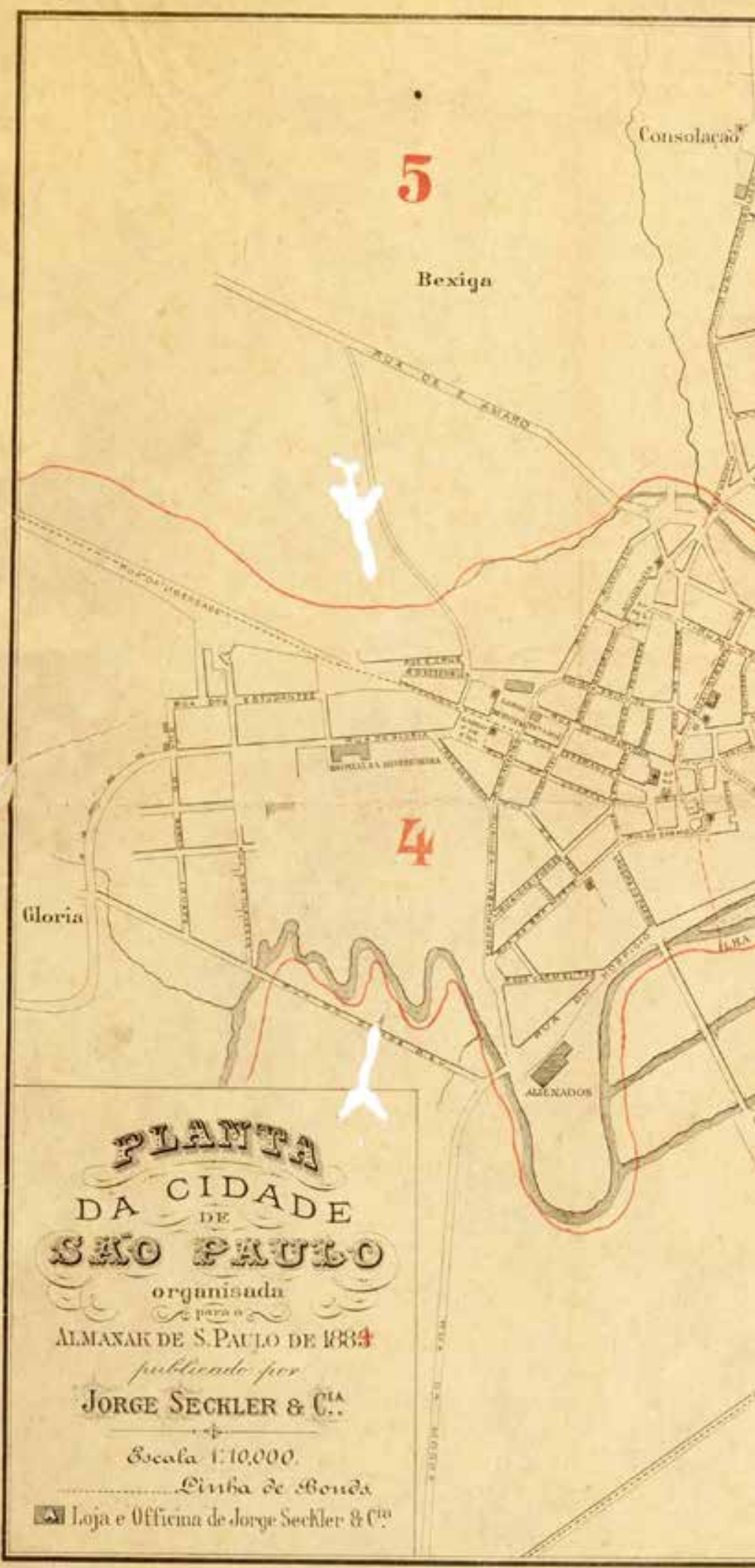




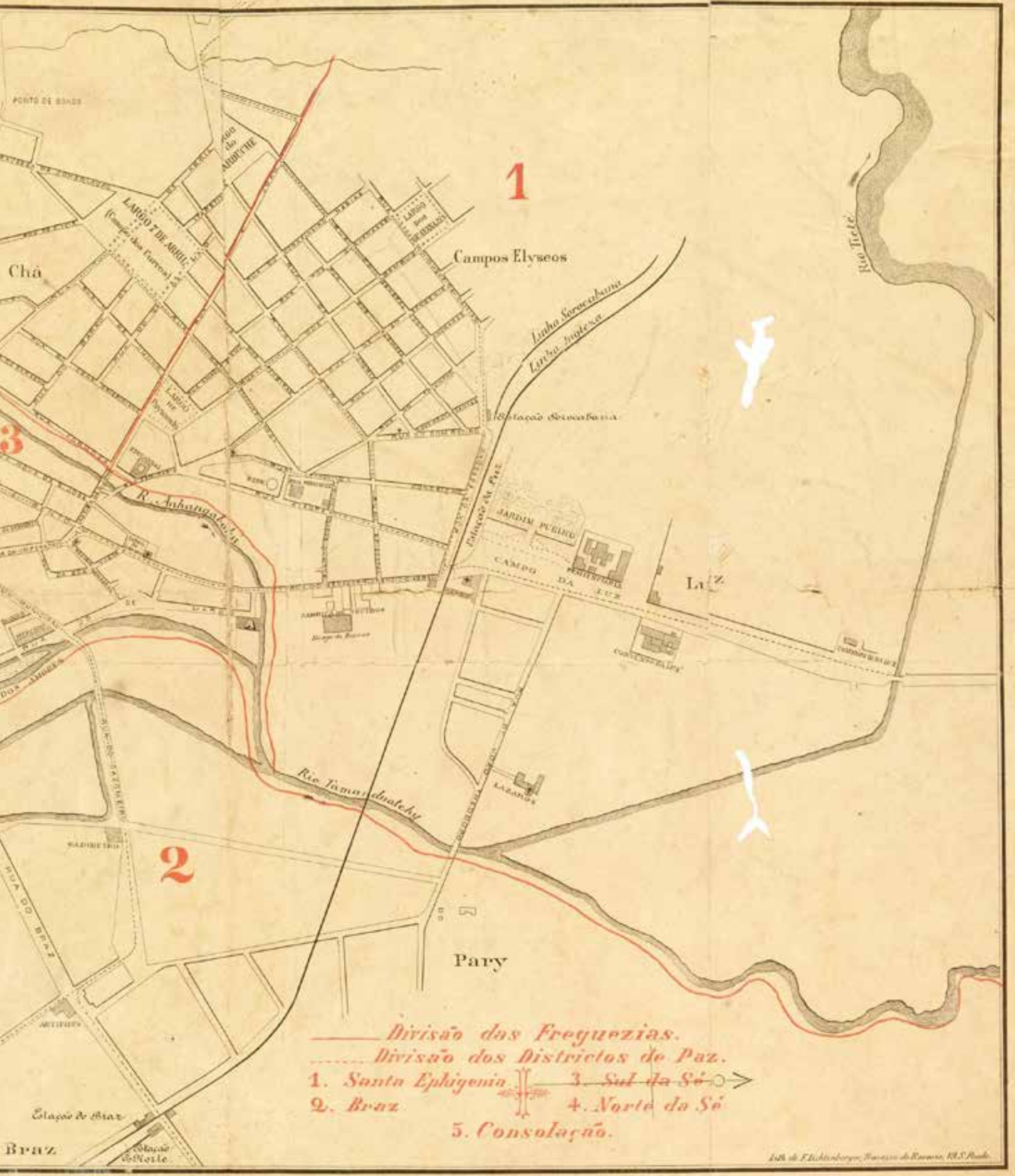


REPARTIÇÃO DE ÁGUAS E ESGOTOS DE S. PAULO

PLANTA DA

CIDADE

$\mathrm{DE}$

SÃO PAULO

COM AS REDES DOS ESGOTOS

Organizada pela

SECÇÃO DE ESGOTOS

ESC. 1:20000

1901

São Paulo - Estado - Repartição de Águas e Esgotos

1:20.000

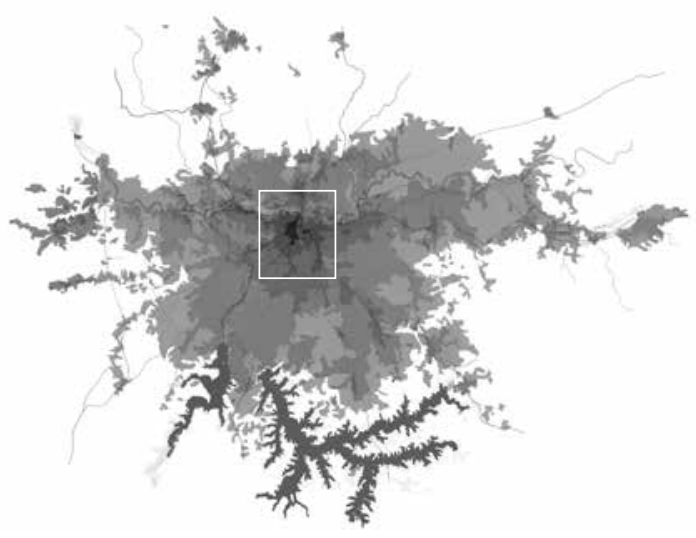




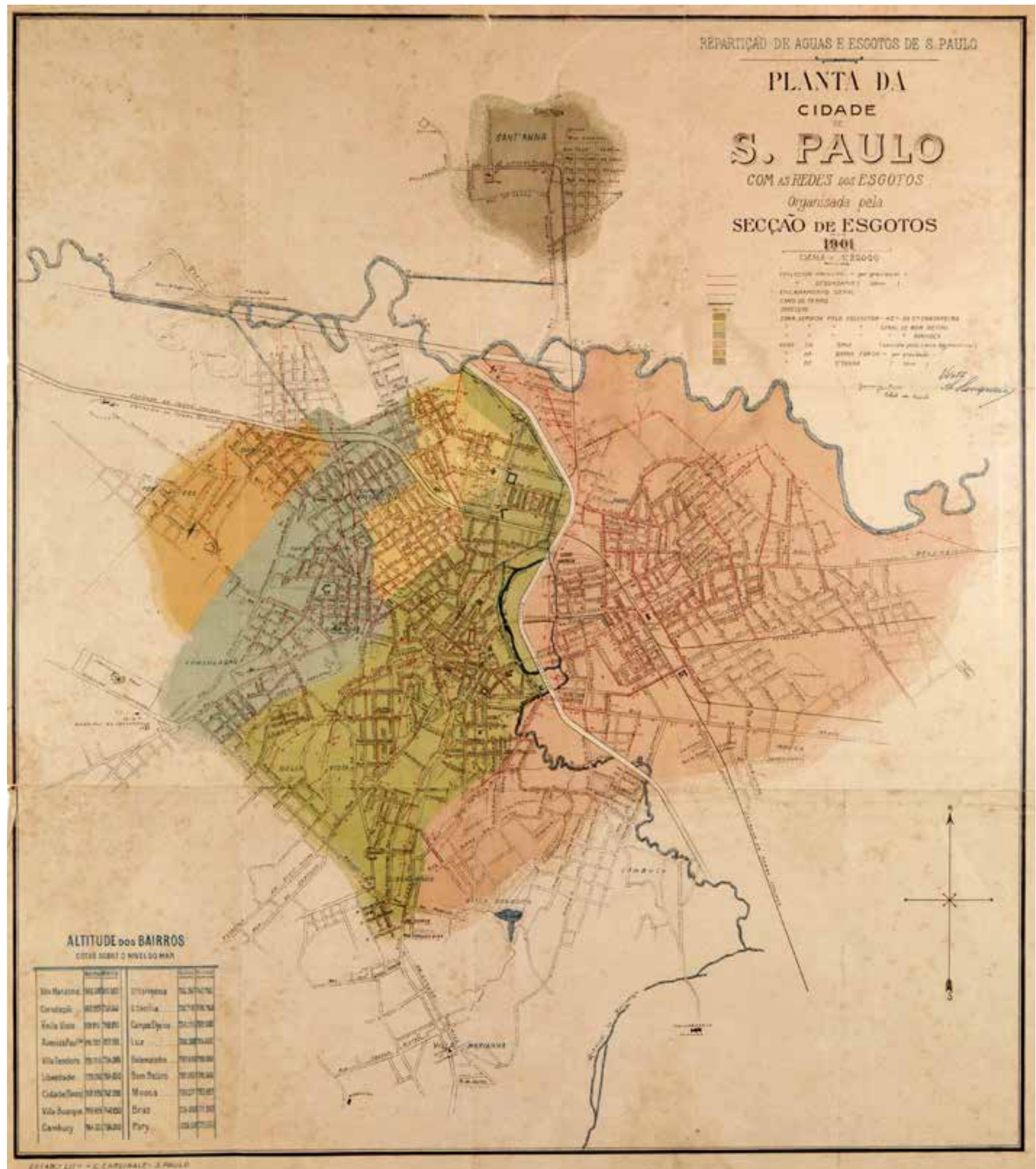


SÃO PAULO

CHÁCARAS, SÍTIOS E FAZENDAS, AO REDOR DO CENTRO

(desaparecidos com o crescer da Cidade) Escala 1:20.000

séculos XIX e XX

Aguirra, João Baptista de Campos $1: 20.000$

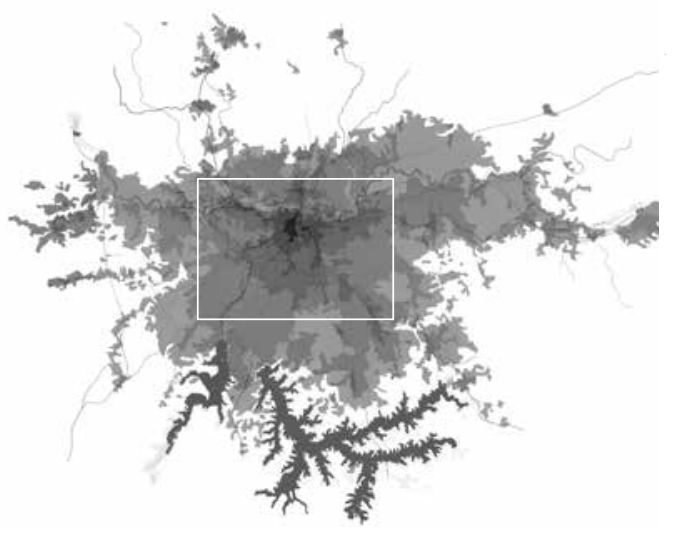

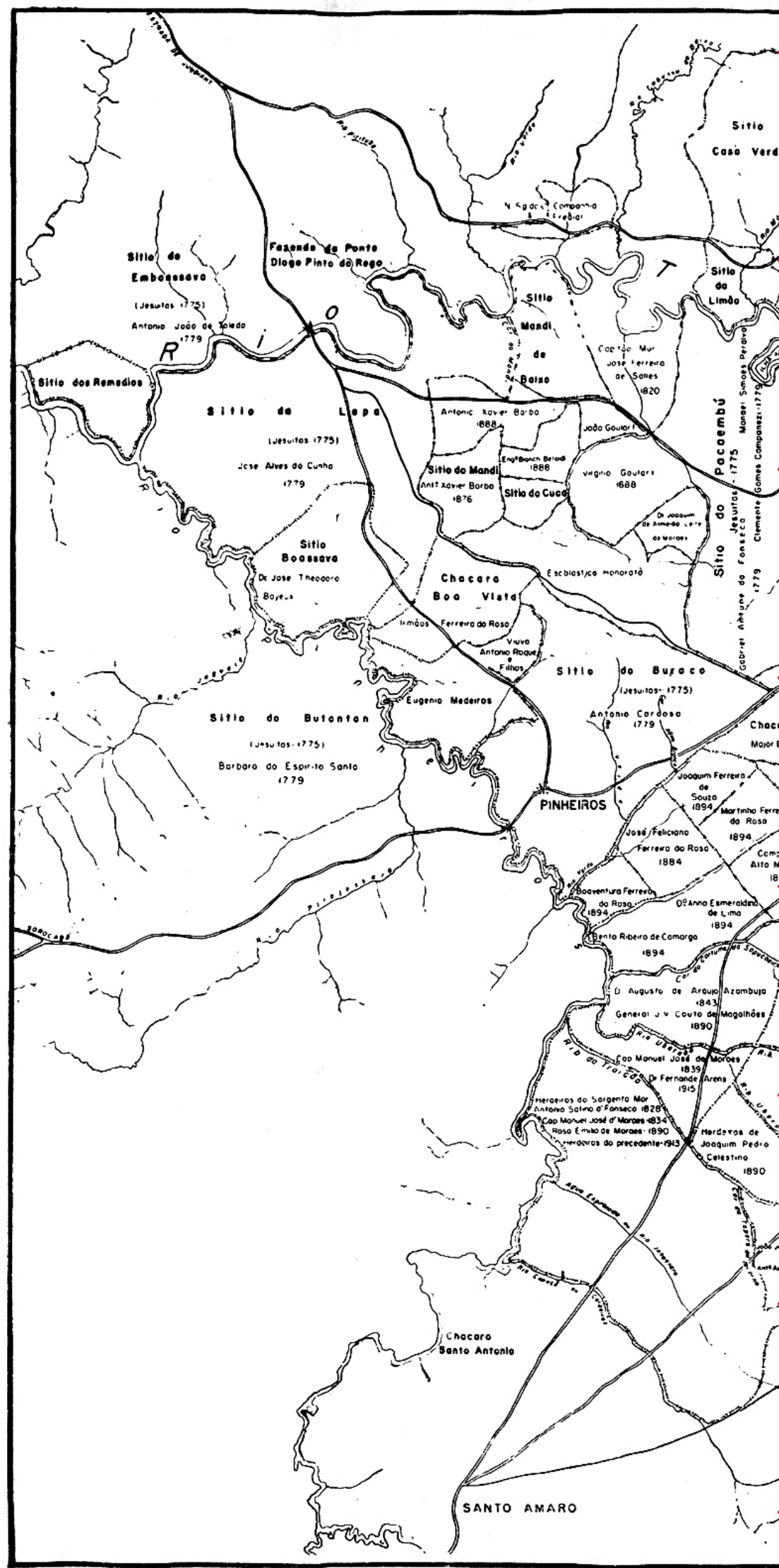




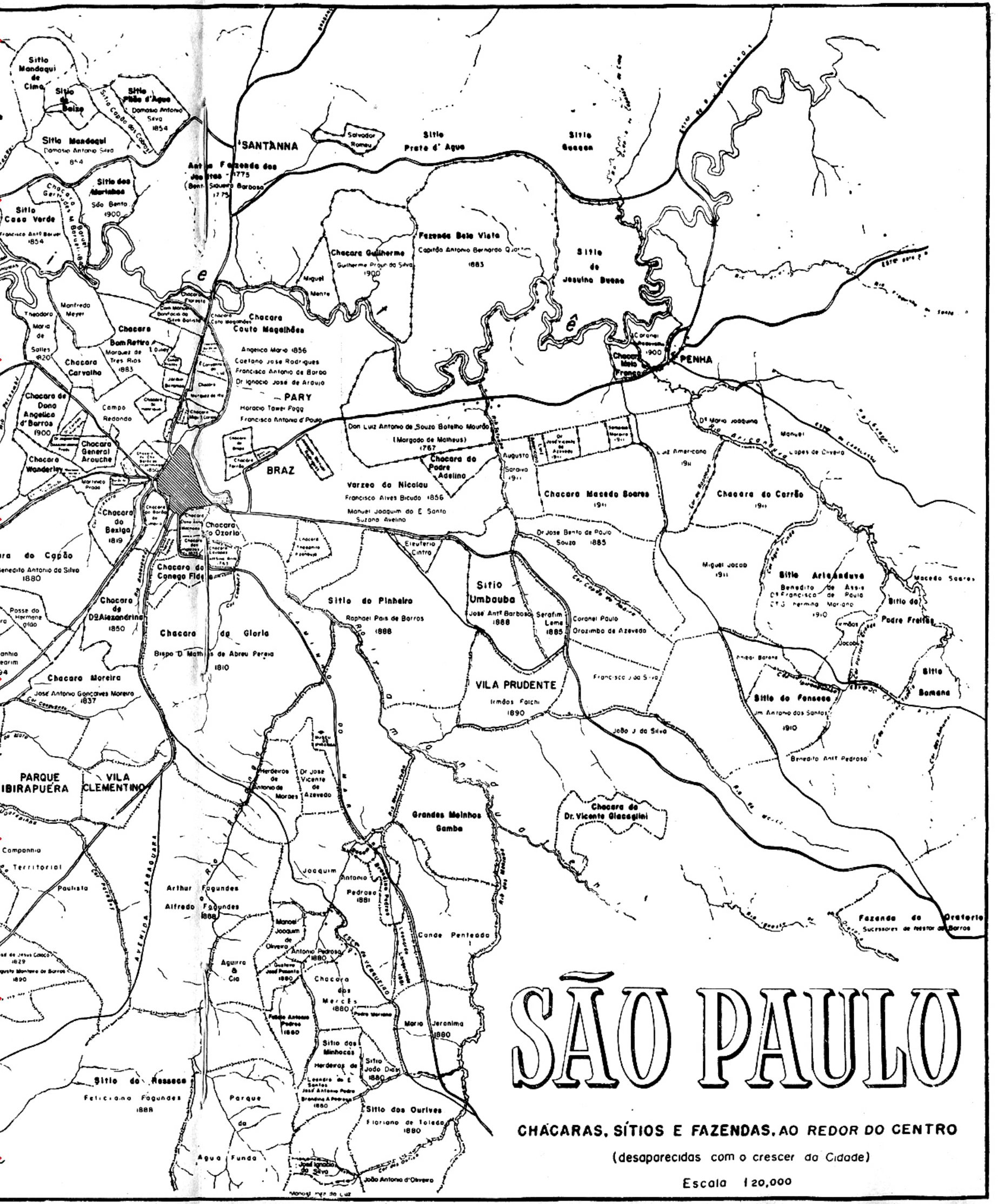


MAPA DAS CHÁCARAS DE SÃO PAULO

séculos XIX e XX

Aguirra, João B. C. (redesenhado por Gouvêa, José Paulo) Escala Gráfica

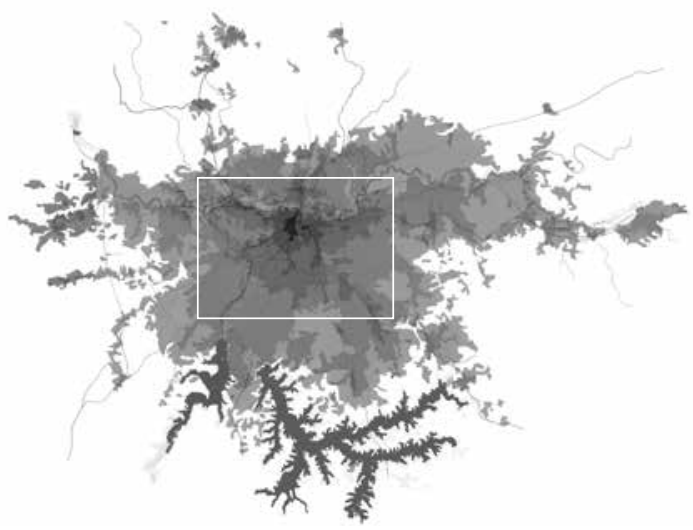

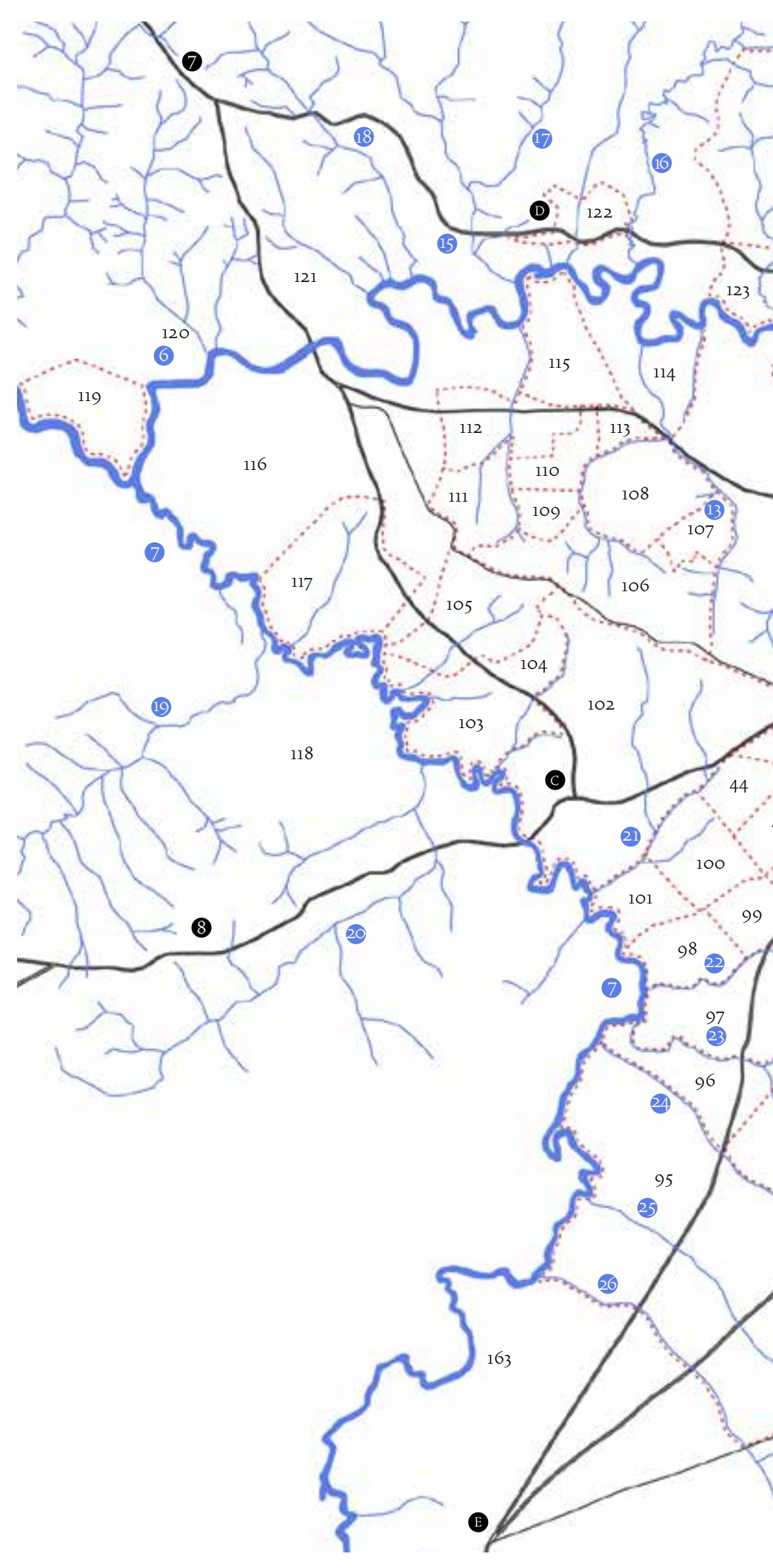




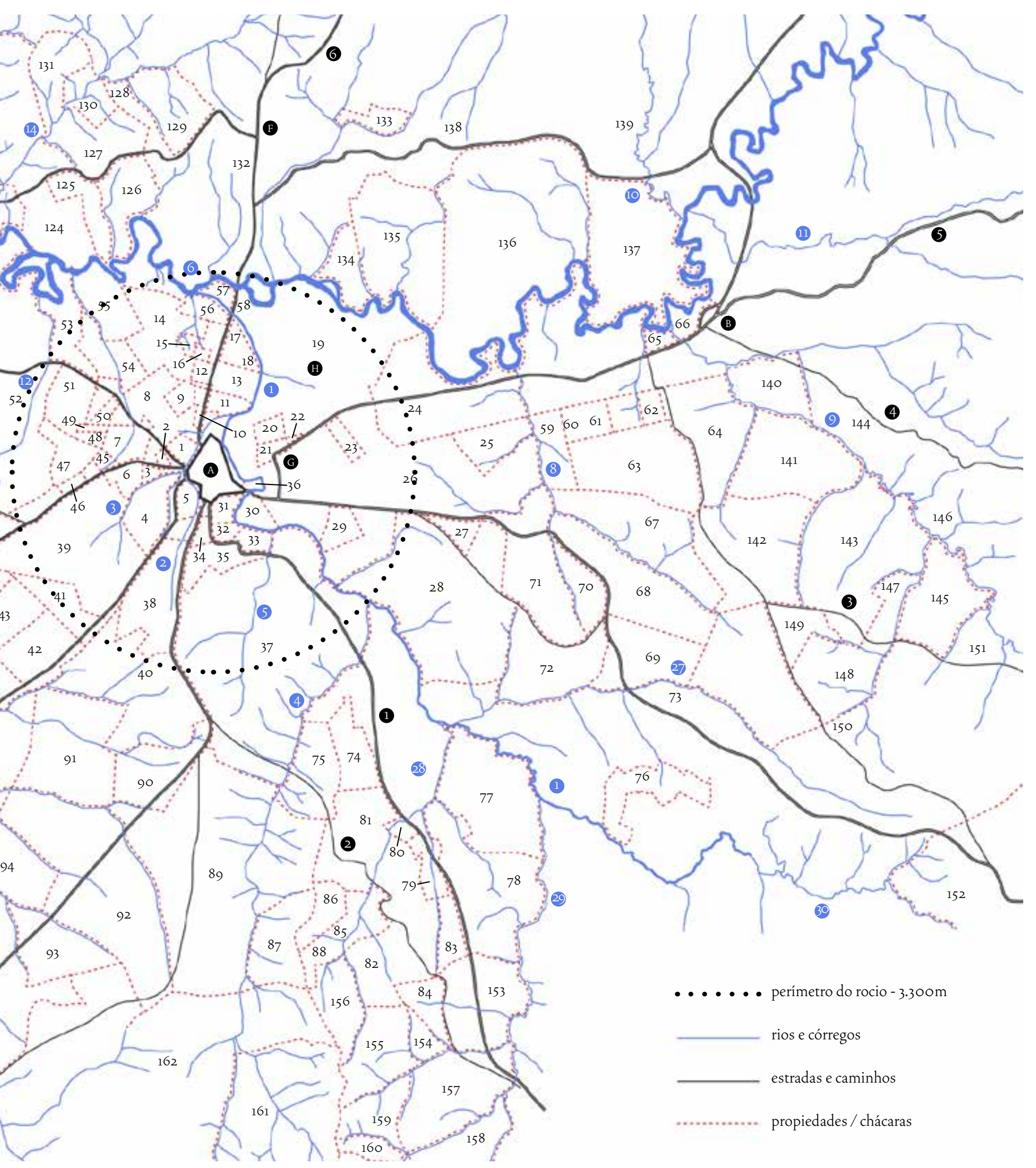


LEGENDA:

NÚCCLEOS:
A. São Paulo
B. Penha
C. Pinheiros
D. Nossa Senhora do Ó
E. Santo Amaro
F. Sant'Anna
G. Braz
H. Pary

CAMINHOS E ESTRADAS:

1. Caminho do Mar

2. Estrada do Vergueiro

3. Estrada do Caaguassú

4. Estrada do Caaguassú

5. Estrada para o Rio

6. Bragança

7. Estrada para Jundiahy

8. Sorocaba

9. Estrada de Guarulhos

RIOS E CÓRREGOS:

1. Tamanduateí

2. Anhangabaú

3. Saracura

4. Ipiranga

5. Cambuci

6. Tietê

7. Pinheiros

8. Tatuapé

9. Aricanduva

10. Cabussú de Cima

11. Tiquatira

12. Pacaembu

13. Água Branca

14. Mandaqui

15. Piqueri

16. Cabussú de Baixo

17. Verde

18. Pirituba

19. Jaguaré

20. Pirajussara

21. Verde

22. Sapateiro

23. Uberaba

24. Traição

25. Jabaquara

26. Cupecê
27. da Moóca

28. Moinho Velho

29. dos Meninos

30. do Oratório

PROPRIETÁRIOS DE CHÁCARAS E SÍTIOS:

1. Chácara do Chá - Barão de Itapetininga - 1850

2. Souza Queiroz

3. Barão de Ramalho

4. Chácara do Bexiga - 1819

5. Chácara do Barão de Limeira

6. Martinho Prado

7. Chácara General Arouche

8. Campo Redondo

9. Chácara do Henrique

10. Brigadeiro Tobias

11. Senador Queiroz + Chácara Miguel Carlos

12. Jardim Botânico

13. Chácara Marquez de Itu

14. Chácara Bom Retiro

Marquez de Trêz Rios - 1883

15. Dulley

16. Conde Prates

17. Chácara Barão de Antonina

18. Convento da Luz

19. Angélica Maria - 1856

Caetano José Rodrigues

Francisco Antonio de Borba

Dr. Ignacio José de Araújo

Horacio Tower Fogg

Francisco Antonio de Paula

20. Chácara do Bispo

21. Chácara Ferrão

22. Mons. Andrade

23. Joaquim Manuel Rodrigues

24. Don Luiz Antonio de Souza Bote-

lho Mourão

(Morgado de Matheus) - 1767

25. Chácara do Padre Adelino

26. Várzea do Nicolau

Francisco Alves Bicudo - 1856

Manuel Joaquim do E. Santo

Suzana Avelino

27. Eleuterio Cintra

28. Sítio do Pinheiro

Raphael Paes de Barros - 1888

29. Chácara Theophilo Azambuja

30. Chácara do Ozório
31. Chácara Dona Anna Machado

32. Chácara dos Inglezes - 1825

33. Chácara Lavapés - Antonio Silva Brito - 1743

34. Chácara Fagundes

35. Chácara do Conego Fidelis

36. Chácara das Freiras

37. Chácara da Glória

Bispo D. Matheus de Abreu Pereira $-1810$

38. Chácara de Dona Alexandrina 1850

39. Chácara do Capão

Major Benedito Antonio da Silva 1880

40. Chácara Moreira

José Antonio Gonçalves Moreira 1837

41. Posse do Hermenegildo

42. Companhia Alto Mearim - 1894

43. Martinho Ferreira da Rosa - 1894

44. Joaquim Ferreira de Souza - 1894

45. Mackenzie - Dr. Horácio Lane

46. Cemitério da Consolação

47. Chácara Wanderley

48. Dona Veridiana Prado

49. Dr. Jaguaribe

50. Dr. Candido Rodrigues

51. Chácara de Dona Angélica de Barros - 1900

52. Sítio do Pacaembu Jesuítas - 1775

Gabriel Antunes da Fonseca - 1779 Clemente Gomes Camponezes -

1779

Manuel Simões Peralva - 1779

53. Theodora Maria de Salles - 1820

54. Chácara Carvalho

55. Manfredo Meyer

56. Com. Bonifácio da Silva Baptista

57. Chácara Floresta

58. Chácara Couto Magalhães

59. Augusto Saraiva - 1911

6o. Luiz Americano

61. Dr. José Vicente de Azevedo - 1911

62. Sampaio Moreira - 1911

63. Chácara Macedo Soares - 1911

64. Luiz Americano - 1911

65. Chácara Melo Franco

66. Coronel Rodovalho - 1900 
67. Dr. José Bento de Paula Souza 1885

68. Coronel Paulo Orozimbo de Azevedo

69. Francisco J. da Silva

70. Serafim Leme - 1885

71. Sítio Umbauba

José Antonio Borba - 1888

72. Vila Prudente

Irmãos Falchi - 1890

73. João J. da Silva

74. Dr. José Vicente de Azevedo

75. Herdeiros de Antonio de Moraes

76. Chácara do Dr. Vicente Giacaglini

77. Grandes Moinhos Gamba

78. Conde Penteado

79. Brandina A. Pedroso

8o. Sacoman

81. Joaquim Antonio Pedroso - 1881

82. Chácaras das Mercês - 1880

83. Leonardo Langechard - 1881

84. Pedro Mariano

85. Antonio Pedroso - 1880

86. Manuel Joaquim de Oliveira

87. Aguirra \& Cia.

88. Gustavo José Pimenta - 1880

89. Arthur Fagundes e Alfredo Fagundes -1888

90. Vila Clementino

91. Parque Ibirapuéra - Próprio Municipal

92. Companhia Territorial Paulista

93. João José de Jesus Colaço - 1829

Antonio Augusto Monteiro de

Barros - 1890

94. Herdeiros de Joaquim Pedro Celestino -1890

95. Herdeiros do Sargento Mor Antonio Safino da Fonseca - 1828

Cap. Manuel José de Moraes - 1834

Rosa Emília de Moraes - 1890

Herdeiros da precedente - 1913

96. Cap. Manuel José de Moraes - 1839

Dr. Fernando Arens - 1915

97. Dr. Augusto de Araújo Azambuja -

1843

General J.V. Couto de Magalhães

$-1890$

98. Bento Ribeiro de Camargo - 1894

99. Dona Anna Esmeraldina de Lima
$-1894$

100. José Feliciano Ferreira da Rosa

$-1894$

101. Boaventura Ferreira da Rosa -

1894

102. Sítio do Buraco (Jesuítas - 1775)

Antonia Cardoso - 1779

103. Eugenio Medeiros

104. Viúva Antonio Roque e Filhos

105. Chácara Boa Vista

Irmãos Ferreira da Rosa

106. Escolástica Honorata

107. Dr. Joaquim de Almeida Leite de

Moraes

108. Virgilio Goulart - 1888

109. Sítio do Cuca

110. Eng. Bianchi Betolo - 1888

111. Sítio do Mandi

Antonio Xavier Borba - 1876

112. Antonio Xavier Borba - 1888

113. João Goulart

114. Capitão Mor José Ferreira de

Salles - 1820

115. Sítio Mandi de Baixo

116. Sítio da Lapa (Jesuítas - 1775)

José Alves da Cunha - 1779

117. Sítio Boassava - Dr. José Theodoro Bayeux

118. Sítio Butantan (Jesuítas - 1775)

Barbara do Espírito Santo - 1779

119. Sítio dos Remédios

120. Sítio do Emboassava (Jesuítas -

1775)

Antonio João de Toledo - 1779

121. Fazenda da Ponte - Diogo Pinto

do Rego

122. Companhia Predial

123. Sítio do Limão

124. Sítio Casa Verde

Francisco Antonio Baruel - 1854

125. Chácara Baruel

Gertrudes M. Baruel - 1845

126. Sítio dos Morrinhos - São Bento

$-1900$

127. Sítio Mandaqui - Damasio Antonio Silva - 1854

128. Sítio Capão das Cabras

129. Sítio Pilão D'água - Damasio

Antonio Silva - 1854

130. Sítio de Baixo
131. Sítio Mandaqui de Cima

132. Antiga Fazenda dos Jesuítas -

1775

Bento Siqueira Barbosa - 1779

133. Salvador Romeu

134. Miguel Mente

135. Chácara Guilherme

Guilherme Prado da Silva - 1900

136. Fazenda Bela Vista

Capitão Antonio Bernardo Quar-

tim -1883

137. Sítio de Jesuíno Bueno

138. Sítio Prato d'Água

139. Sítio Guacon

140. Dona Maria Joaquina

141. Chácara do Carrão - 1911

142. Miguel Jacob - 1911

143. Sítio Aricanduva

Benedito de Assis

Dona Francisca de Paula

Dona Guilhermina Mariano -

1910

144. Manuel Lopes de Oliveira

145. Sítio do Padre Freitas

146. Macedo Soares

147. Irmãos Jacob

148. Sítio do Fonseca

Jm. Antonio dos Santos - 1910

149. Aníbal Barone

150. Benedito Antonio Pedrosa

151. Sítio Bomand

152. Fazenda do Oratório

Sucessores de Nestor de Barros

153. Maria Jeronima - 1880

154. Sítio João Dias - 1880

155. Sítio das Minhocas

Herdeiros de Leandro do E. Santo

José Antonio Pedroso

Brandino A. Pedroso - 1880

156. Felicio Antonio Pedroso - 1880

157. Sítio dos Ourives

Floriano de Toledo - 1880

158. João Antonio de Oliveira

159. José Ignacio da Silva

160. Manuel J. da Luz

161. Parque da Água Funda

162. Sítio da Ressaca

Feliciano Fagundes - 1888

163. Chácara Santo Antonio 

CAPÍTULO 5 - APROPRIAÇÃO DA ÁGUA

Durante o último quarto do século XIX, a cidade de São Paulo passava por um processo de urbanização que a levaria para além da colina e dos rios que a limitavam - ver mapas das páginas 146-147 e 148-149. A expansão física e econômica da cidade foi um reflexo direto da cultura do café, que estimulou o crescimento do comércio, da indústria e do mercado financeiro e hipotecário na capital. Os desdobramentos do cultivo do café fizeram com que fazendeiros, empresários e funcionários do governo se instalassem na cidade. $O$ crescimento populacional foi acompanhado pelo incremento da urbanização. A imigração, que acontecia para fomentar a produção rural, também teve forte reflexo na cidade com imigrantes que tentavam nela encontrar trabalho e moradia como uma alternativa ao trabalho rural. ${ }^{149}$

Assim como foi analisado, a introdução da moderna propriedade da terra e sua institucionalização, com a promulgação da Lei de Terras em 1850, foi essencial para o estabelecimento das relações de produção capitalistas na província e na cidade de São Paulo. Na cidade, fator importante para a constituição dessas relações foi o assalariamento, que no decorrer da segunda metade do século XIX passou a ser mais utilizado como forma de remuneração do trabalho. (PEREIRA, 2004)

149. PEREIRA, Paulo Cesar Xavier. São Paulo - a construção da cidade - 1872-1914. São Carlos, Rima, 2004. 
Assim como observa Paulo Cesar Xavier Pereira ao estudar a atividade da construção na cidade, o assalariamento pôde coexistir com o trabalho escravo. No caso específico da construção, em São Paulo, essa atividade foi, primordialmente, realizada por trabalho livre. A utilização do trabalho escravo pelo colonizador, como auxiliar de construção, implicou diretamente na "formação profissional do cativo", que alcançou qualificação profissional e aperfeiçoamento. (PEREIRA, 2004, p.23)

Até a metade do século XIX, o trabalho escravo era pouco relevante em São Paulo, tendo sido mais empregado a partir do desenvolvimento da cultura do café na província ${ }^{150}$. Os escravos realizavam atividades muito diversificadas, como "escravos de eito, negros de ganho e escravos domésticos". Entretanto, o "escravo assalariado"151 era a modalidade de trabalho escravo que anunciava a complexidade das transformações em curso.

Assim como exposto anteriormente, o capital era aplicado na pessoa do cativo na forma de renda capitalizada. Como o dinheiro pago ao traficante era despendido com base na capacidade do escravo de gerar riqueza, o proprietário se esforçava para tornar permanente a utilização do escravo, como forma de retorno do capital investido, e, no caso da construção, "por meio de seu deslocamento contínuo entre os canteiros de obras [...]". O aluguel de escravos, solução que foi muito utilizada em São Paulo ${ }^{152}$, foi responsável por aumentar a possibilidade de retorno do capital investido, mas também por introduzir uma ambiguidade na produção que colaborou com a constituição do trabalho livre.

150. Florestan Fernandes, ao questionar o mito da "democracia racial" no Brasil, informa que, a partir da abolição da escravatura em maio de 1888, e mesmo antes disso, as classes dominantes não contribuíram para a inserção dos ex-escravos no trabalho livre assalariado, havendo preferência pelo trabalhador imigrante europeu. FERNANDES, Florestan. A Integração do Negro na Sociedade de Classes. São Paulo: Ática, 1978.

151. Como lembra Pereira, "A denominação "escravo assalariado" é uma classificação adotada pelo Recenseamento de 1872 " e trata-se do "aluguel do escravo por seu proprietário. Evidentemente, o escravo não se assalaria por si mesmo, pois não é proprietário de seu trabalho. Contudo, ele é denominado assalariado porque por meio de seu desempenho no trabalho é que seu proprietário recebe um ganho periódico quando o aluga. Trata-se, de fato, de um aluguel que propicia uma renda ao proprietário. [...]" (PEREIRA, 2004, p. 26, nota 6)

152. "Na província de São Paulo, em 1872, considerando as pessoas do sexo masculino assalariadas, a proporção de escravos correspondia a 23,5\% (5.403), a de estrangeiros a apenas $8 \%$ (2.058), sendo a grande maioria dos assalariados - 68,8\% - formada por trabalhadores nacionais." (PEREIRA, 2004, p. 26) 
"Durante o século XIX, à medida que ocorria a desagregação do escravismo e a dinâmica econômica interna se expandia, tornou-se comum o pagamento de salário como retribuição do trabalho, tanto do homem livre como do escravizado. Nesse sentido, a locação de cativos, assemelhada a um assalariamento, significava mais do que manter continuidade e imprimir mobilidade no uso do escravo; implicava quebrar a relação fixa do escravo e de seu senhor, caminhava em direção à negação da própria razão de ser da escravidão. O escravo de aluguel acentuava no seio do próprio escravismo as características mercantis da força de trabalho, expressando contradições dessa organização social." (PEREIRA, 2004, p.28-29)

Assim, o uso do escravo de aluguel denunciava a proletarização do trabalhador e, embora não representasse o "assalariamento pleno e nem massivo", tratava-se "apenas de um processo de proletarização embrionário, que tem sua importância por ser interior à economia e concomitante às primeiras levas imigrantes". O importante a ser considerado é que, apesar de o regime de trabalho escravo ser muito distinto do regime de trabalho livre, do ponto de vista de quem comprava trabalho, seja alugando escravos ou pagando um trabalhador, não existia diferença. (PEREIRA, 2004, p.29)

Essa possibilidade de emprego do trabalho escravo, combinado com o trabalho livre, estabeleceu uma forma de controle da produção mantendo a sujeição dos escravos e reforçando a dependência dos libertos.

A prosperidade econômica, a partir de meados do século XIX, aliada ao alto preço do cativo, à crise da escravidão e ao crescimento das cidades, favoreceu o estabelecimento de atividades urbanas e o desenvolvimento da relação entre mão de obra escrava, forra e livre. É importante notar que, a partir de 1870, à alforria foi associada a hostilidade pela escravidão, exercendo forte pressão para o seu fim e se constituindo em um elemento importante na transição do emprego do trabalho escravo para o emprego do trabalho livre. (PEREIRA, 2004)

Entendendo que a renda capitalizada é a forma dominante do capital, tanto no regime de trabalho escravo quanto no regime de trabalho livre, no meio urbano, houve também uma transição do predomínio da obtenção de renda a partir do escravo para o predomínio da renda obtida a partir da propriedade privada da terra. 
O significado da propriedade do escravo se renovava, passava de uma forma tradicional de riqueza, de instrumento para realizar trabalho, para propriedade de capital, garantindo hipotecas ou rendimentos através do aluguel $^{153}$.

"A locação se modernizava e se diversificava, a propriedade do escravo formalizava-a como força de trabalho, porque, do ponto de vista de quem o alugava, não se comprava o escravo, mas apenas seu trabalho. Nessa modernização e diversificação da propriedade do escravo, toda a sociedade se renovava". (PEREIRA, 2004, p.34)

A propriedade da terra passava a ser considerada, cada vez mais, um patrimônio, independentemente de qualquer exploração produtiva.

"Ambas as propriedades, a do escravo e a da terra, como formas de riqueza, constituíram elementos econômicos que não se originavam no processo produtivo, mas se redefiniam ao assumirem formas novas, modificando a própria relação de produção." (PEREIRA, 2004, p.34)

Assim, como a propriedade do escravo passou a funcionar como capital, a propriedade da terra também passou a assumir essa função passando a proporcionar renda em dinheiro ${ }^{154}$. Ou seja, como afirma Xavier Pereira, à medida que se alterou o significado econômico da propriedade da terra, modificou-se a importância do trabalho escravo como elemento de geração de riqueza. (PEREIRA, 2004, p.37)

Nesse processo, que fundamentava a industrialização em São Paulo, com a metamorfose da propriedade e da renda, emergiu a forma de produção de moradia por encomenda, fazendo com que o interesse pela propriedade se situasse sobretudo na construção de casas para serem alugadas, diminuindo o interesse pela propriedade de escravos. Progressivamente, com o novo significado econômico da propriedade do escra-

153. "Nesse contexto a proletarização embrionária, representada pelo escravo de aluguel transitou de uma renda proporcionada pela concessão do direito de uso do trabalho escravo para uma renda proporcionada pela concessão do direito de uso do trabalho escravo (seu aluguel)." (PEREIRA, 2004, p. 37)

154. "Essa passagem resultou da alteração do significado econômico das relações sociais que haviam modificado o interesse em adquirir ou manter uma ou outra propriedade: a do escravo ou a do imóvel." (PEREIRA, 2004, p. 37) 
vo e da terra, tornou-se mais interessante obter rendas provenientes da propriedade imobiliária.

No contexto das contradições entre o escravismo e a mercantilização da economia urbana, era necessário, para a reprodução do capital, o avanço do trabalho livre como forma de superação do trabalho escravo. A construção da cidade como forma de desenvolvimento capitalista, que inicialmente se manifestou na atividade de construção de moradias, passaria também a se manifestar na necessidade de provisão de serviços urbanos. Nas transformações da propriedade e da renda, terra e trabalho "metamorfosearam-se". (PEREIRA, 2004, p.37)

Continuava em vigor a necessidade de manter afastados da propriedade privada da terra os negros alforriados e a massa de trabalhadores imigrantes, como um fator necessário à consolidação da sujeição do trabalho livre ao capital. No caso da cidade de São Paulo, o impedimento ao livre acesso à propriedade das terras municipais e devolutas do Império constituiu-se ao longo do século XIX, quando as terras do antigo patrimônio do Conselho passaram para as mãos de particulares. A ocupação dessas terras de uso comum, bem como a inviabilidade de utilização das águas e terras dos rios próximos, acabava com as possibilidades de subsistência a partir dos rios, da terra e da água. Sem isso, não seria possível evitar que um homem livre pudesse viver a partir do consumo direto ou de rendas obtidas nos domínios comuns, como a caça, a pesca, a coleta, a extração, entre outras atividades muito comuns em São Paulo ainda durante todo o século XIX e que tenderam a se extinguir a partir do início do século XX.

A abolição e a imigração foram marcos importantes no processo de constituição do mercado de trabalho no Brasil no final do século XIX, com a difusão do trabalho livre no meio rural e do trabalho assalariado no urbano, condições necessárias ao início da proletarização do trabalhador e ao desenvolvimento industrial capitalista. (PEREIRA, 2004, p.39)

A grande quantidade de imigrantes que chegavam à São Paulo evidenciou a crescente importância da cidade no contexto nacional, provocando a sua consolidação como centro urbano e polo distribuidor de mercadorias e absorvedor de mão de obra. Fazendeiros de café começavam a passar mais tempo na cidade para tratar de negócios financeiros e comerciais, ficando claro que o modo de vida tradicional passava a ser incompatível com as demandas exigidas na gestão da moderna empresa 
capitalista. Dessa forma, pode-se afirmar que o rápido crescimento industrial e urbano de São Paulo se deveu principalmente à concentração de capital e trabalho. Assim, a massa de mão de obra, sobretudo estrangeira, serviu ao capital tanto na acumulação agrária quanto na acumulação industrial. (PEREIRA, 2004)

O rápido crescimento da cidade significou a ampliação do mercado de trabalho com a instalação de fábricas e o uso de maquinário em diversas atividades industriais, refletindo a emergência de novas relações sociais de produção.(PEREIRA, 2004)

Com os desdobramentos e as implicações da cultura do café a cidade floresceu ${ }^{155}$. O adensamento do centro da cidade, passou a ser acompanhado pela produção imobiliária extensiva através do loteamento das chácaras e grandes terrenos e em locais mais valorizados, iniciando a ocupação das ancestrais terras de domínio comum, o rocio, e também das várzeas do rio Tamanduateí. A massa de imigrantes era empregada na cidade e o capital ${ }^{156}$ oriundo da produção do café era aplicado na construção de casas de aluguel e conjuntos residenciais para operários e para a classe média. A intenção era a europeização da cidade ${ }^{157}$ que passava

155. A gestão de João Teodoro Xavier, entre os anos de 1872 e 1875, favoreceu a modernização das construções da capital de um modo tão forte que o período ficou conhecido como a "segunda fundação de São Paulo". Segundo Xavier Pereira, "edifícios de taipa foram demolidos. No lugar da cidade antiga começou-se a construir uma nova cidade, agora toda de alvenaria. Quanto à atividade urbana, pode-se considerar que a cidade cresceu sobre si mesma, pois, inicialmente o aumento da área urbanizada não foi significativo. Na verdade, nessa mera substituição de edifícios é que se situava o segredo do incipiente crescimento urbano, por meio da renovação da Capital a partir da reconstrução da cidade sobre si mesma." (PEREIRA, 2004, p.46)

156. "[...] poucos poderiam ter sido mais claros que Henrique Raffard, nascido no Rio de Janeiro e filho do cônsul-geral da Suiça, de formação acadêmica européia e importante homem de negócios. Para ele, os "capitais paulistas conservaram-se tímidos por muitos anos e só apareciam quando garantidos por boas hipotecas a juros elevadíssimos [...]. Mas prevendo a extinção da escravidão e, consequentemente, a depreciação das propriedades agrícolas, e temendo a baixa de todo título particular ou público [...], os capitais paulistas atiraram-se então sobre os prédios e os terrenos da Paulicéia [...] a fim de dar emprego a seus dinheiros desocupados". RAFFARD, H. Alguns dias na Paulicéia. São Paulo: Academia Paulista de Letras, 1977.

157. A cidade se "modernizava". Os fazendeiros que vinham se estabelecer na capital miravam a cultura européia, resultando, dessa prosperidade econômica, o projeto de europeização de São Paulo. Esse projeto favoreceu o trabalhador livre estrangeiro que era preferido em relação ao trabalhador nacional. A Câmara Municipal começaria a estabelecer restrições às construções na região central, 
por sua reconstrução. Assim, os investimentos passavam a se concentrar mais na produção imobiliária e a propriedade da terra passou a ser mais interessante que a propriedade do trabalhador cativo, agora considerada arriscada devido à iminência da abolição da escravatura. A formação de preços de monopólio da terra e a consequente expectativa de elevação dos preços dos imóveis fazia do negócio imobiliário uma atividade muito rentável. A valorização do capital aplicado na construção retorna tanto através da renda como também através da exploração do trabalho na construção.

O aumento do valor da propriedade imobiliária, expressa na elevação dos preços de mercado, começava a combinar capitalização e valorização; "a primeira, mediante o simples aumento dos preços de mercado dos imóveis, muitas vezes especulativamente, a partir da intermediação de corretores e loteadores, e a segunda, pela construção destinada ao mercado de imóveis em formação". Essa "construção social do setor econômico da propriedade", como denominou Xavier Pereira, teve seu impulso inicial com as construções de luxo para locação em bairros exclusivos destinados à nova burguesia. Agora, os fazendeiros

“[... eram obrigados a residir mais tempo na cidade, junto das repartições públicas e particulares, em contato com os organismos políticos; as demoras nos domínios rurais começavam a encurtar: a casa rural perdia em austeridade o que ganhavam em elegância para estadas confortáveis, mas, ao mesmo tempo, a casa da cidade passava a ser residência principal, objeto de todos os cuidados, manifestação exterior da riqueza de seu proprietário." 158

modelando o aspecto da cidade e restringindo o uso de sistemas construtivos tradicionais, "a velha taipa começou a ser substituída pelo tijolo". (PEREIRA, 2004, p.46) As construções residenciais agora abrigavam famílias mais abastadas, enriquecidas com a produção do café. Os porões altos separam o interior dos olhares da rua, as vidraças substituem as janelas de tábua e permitem que a luz entre nas casas. Aparecem os recuos que, primeiramente laterais, alcançam pouco tempo depois a total independência e isolamento da edificação em relação ao lote. A sala de visitas surge para selecionar o público numa crescente oposição ao espaço da rua que se tornaria um espaço de circulação por excelência. (ROLNIK, 2003)

158. MONBEIG, p. La croissence de la ville de São Paulo. Grenoble: Institut et Revue de Geographie Alpine, 1953 apud PEREIRA, 2004, p. 48. 
Antigos edifícios coloniais desapareciam da cidade, que crescia rapidamente, alterando a estrutura urbana, aumentando a mobilidade territorial e social da população.

"À medida que o século XIX terminava, a alusão ao congestionamento nas estreitas ruas da capital e, tanto nas Atas da Câmara Municipal como na imprensa do período, há várias menções à necessidade de disciplinar o trânsito, ordenar as ruas, regularizá-las e introduzir alguma racionalidade em um desenho considerado caótico"159 (ROLNIK, 2003, p.31).

Vale reforçar que esses são apenas os primeiros passos de um mercado imobiliário que se instituía e que, cada vez mais, vinculava mercado de trabalho aos espaços arquitetural e urbano. Apenas quando a economia de mercado estivesse desenvolvida é que a atividade de construção apresentaria o trabalhador em sua dupla face: como produtor e como consumidor de casas." Nesse primeiro momento, o trabalhador pouco adquiriu. O mercado imobiliário se concentrou na produção de construções de luxo, passando em seguida à produção de casas de aluguel a preços altos, ficando o trabalhador "limitado ao segmento inferior do mercado, adquirindo lotes distantes ou morando em cubículos de aluguel". (PEREIRA, 2004, p. 49)

\section{A COMPANHIA CANTAREIRA DE ÁGUAS E ESGOTOS}

Além do investimento na construção de edifícios, passou-se a investir também na provisão de infraestrutura urbana, como a instalação das ferrovias e das redes de água e esgoto, ampliando assim as formas de valorização da propriedade da terra. Esses empreendimentos buscavam a valorização do capital através da exploração do trabalho realizado na construção das infraestruturas e também através da venda e distribuição de serviços como gás, água e esgoto. Além dessas duas forma de valorização do capital, a provisão desses serviços promovia a valorização dos imóveis próximos, propiciando o incremento do valor de mercado dos edifícios e lotes servidos, aumentando a possibilidade de obtenção de renda. No

159. ROLNIK, Raquel. A Cidade e a Lei: legislação, política urbana e territórios na cidade de São Paulo, São Paulo: Studio Nobel: Fapesp, 2003. 
momento em que era necessário equipar São Paulo com condições gerais de produção, como forma de reforçar a cidade como um centro produtivo, o capital proveniente da cultura do café e também estrangeiro passariam a ser aplicados nessa tripla possibilidade de valorização propiciada pela provisão de serviços urbanos.

Ainda que a cidade tenha "florescido", como foi dito, a partir da capitalização do trabalho, o fornecimento de água da cidade permanecia extremamente precário. Simplesmente não existia rede de esgotamento: os despejos continuavam a ser feitos diretamente nos rios Anhangabaú e Tamanduateí além de outros córregos. $\mathrm{O}$ aumento da população aliado à fragilidade estrutural do fornecimento de água e a frequentes períodos de seca agravava muito a situação. Água e esgoto eram estruturas mínimas, sem as quais o estabelecimento de condições gerais de produção não se viabilizava. As pretensões de valorização do capital através da propriedade da terra e do trabalho encontravam na precariedade das redes que envolviam os rios e a água um grande obstáculo. Se a função da cidade passava a ser a reprodução de capital, seria necessário enfrentar o problema.

Em meados do século XIX, as propriedades estavam pulverizadas pelos arredores do núcleo urbanizado nas mãos de diversos proprietários e construtores. A riqueza estava diluída nas mãos de diversos pequenos proprietários, refletindo-se na própria estruturação do espaço. A partir do novo significado da propriedade da terra e do trabalho, a tendência seria a acumulação do espaço, incluindo a necessidade de concentração de terra e água.

A presença do café na província representou uma inflexão nos padrões de desenvolvimento da cidade de São Paulo. De 1872 a 1890, São Paulo passou por um enorme crescimento populacional, dobrando o número de habitantes da cidade, de 31.385 a 64.934. Na década seguinte, a população quadruplicaria. Os limites da cidade, que até então se limitava ao triângulo central, se expandem para chácaras próximas em loteamentos "empíricos" e de forma desordenada ${ }^{160}$. Segundo Jorge Oseki, "qualitativamente a cidade explode (e implode)". ${ }^{161}$

16o. TOLEDO, Benedito Lima de. São Paulo: três cidades em um século. São Paulo: Cosac Naify, 2004.

161. Ao norte foi loteada a chácara Mauá (ou Campo Redondo), a do Miguel Carlos e a do Bom Retiro; ao leste as chácaras do Figueira e do Fernão, ao sul as chácaras do Barão de Limeira, de Anna Machado, do Ozório (ou do Menezes), do Fagundes, do Cônego Fidélis, da Glória e do Luiz do Lavapés e a oeste as chácaras 
Nessa época tiveram início obras de infraestrutura visando resolver problemas urbanos e também realizar embelezamentos na cidade. As margens do Tamanduateí - a várzea do Carmo - começou a ser saneada a partir da instalação de um passeio público e da construção da Ilha dos Amores. As obras aconteceram às margens do rio mas também sobre o rio com a obra do aterro do Gasômetro e a rua Conde d'Eu (rua do Glicério). Ainda nesse período foram executadas ruas de conexão importantes e a regularização do largo do Curro (atual Praça da República) e do parque da Luz, em frente à nova estação de trens, que foi replanejada. No núcleo histórico fez-se o calçamento de paralelepípedos em importantes ruas centrais. (TOLEDO, 2004)

O problema de abastecimento se coloca, diante desse aumento populacional, com a insuficiência de água em fontes e vertentes próximas ao núcleo. Não se tratava mais do número de chafarizes ou da quantidade ou qualidade da tubulação, mas sim a falta de água, sobretudo em períodos de seca. (OSEKI, 1992) Para esse fim foram realizadas algumas obras por engenheiros contratados pelo Governo Provincial que, entretanto, não surtiram efeito no abastecimento, sendo necessárias obras de maior porte.

A partir da segunda metade do século XIX, diante dessas deficiências na distribuição de água, o debate sobre a solução do problema ganhou força entre especialistas. As disputas, basicamente, giravam em torno da possibilidade de captar as águas do Tietê, a montante da cidade, ou da serra da Cantareira ${ }^{162}$.

O ribeirão da Pedra Branca, na serra da Cantareira ${ }^{163}$, ao norte do Tietê, teve suas águas analisadas pelo farmacêutico Gustavo Schaumann, sendo constatado que eram de boa qualidade. (OSEKI, 1992)

Em 1860, o engenheiro britânico James Brunlees e uma equipe de engenheiros ingleses foram contratados pelo Governo Provincial para a realização de um plano geral de abastecimento da cidade, utilizando, sobretudo, os recursos da serra da Cantareira. Como parte dos estudos, Brunlees e equipe realizaram um levantamento topográfico, demarcan-

do Senador Queiroz, de Martinho da Silva Prado e do Marechal Arouche. OSEKI, Jorge H.. Pensar e Viver a Construção da Cidade: Canteiros de Desenhos de Pavimentação, Drenagem de Águas Pluviais e Redes de Esgoto em São Paulo. Tese de doutoramento, FAUUSP, São Paulo 1992, p.11.

162. Havia ainda quem defendesse a captação das águas do Tamanduateí.

163. "Essas águas para serem bebidas eram distribuídas em cântaros, o que deu o nome à serra." (OSEKI, 1992, p.14)

\begin{tabular}{lll} 
ano & população & crescimento \\
\hline 1872 & 31.385 & - \\
1886 & 47.697 & $52 \%$ \\
1890 & 64.934 & $36 \%$ \\
1900 & 239.820 & $269 \%$ \\
1910 & 375.000 & $56 \%$ \\
1920 & 579.033 & $54 \%$ \\
1934 & 1.060 .120 & $83 \%$ \\
1940 & 1.337 .644 & $26 \%$ \\
1950 & 2.198 .096 & $65 \%$ \\
1960 & 3.825 .351 & $74 \%$
\end{tabular}


tabela 1: crescimento populacional da cidade de São Paulo 1872-1960 (fontes: SINGER, Paul. Desenvolvimento Econômico e Exclusão Urbana e PETRONE, Pasquale. A cidade de São Paulo no século XX apud OSEKI, 1992.) do todos os recursos hídricos da região. Influenciados pelo interesse de proprietários de terra na região e de empresários na possibilidade de exploração de serviços públicos e na realização dessa obra, os técnicos declararam que essa captação resolveria "plenamente" problema da falta d’água na cidade.

Em meio a desconfianças e longe de ser uma unanimidade, em 1864, Brunlees entrega o seu relatório ao governo. Nesse relatório, constavam os valores necessários para a realização da obra, considerados totalmente fora dos padrões de gastos da província. $O$ empreendimento permaneceria sem qualquer progresso até a década seguinte.

Segundo atestou o relatório do presidente da Província, dr. Francisco Ignacio Marcondes Homem de $\mathrm{Mello}^{164}$, a realidade financeira da província não permitia a realização das obras de canalização das águas da Cantareira, considerada uma obra dispendiosa, continuando, portanto, o "quase secular" problema de abastecimento de água potável da capital. ${ }^{165}$ (FREITAS, 1985 , p.32)

Segundo Affonso de Freitas, "uma das maiores secas de que há memória na Pauliceia teve lugar em 1866-1867: reinava então em todo o Brasil um tempo quente em consequência da guerra contra o Paraguai." Assim como foi mencionado anteriormente, o presidente da província estava absorvido com a campanha paulista na guerra de forma que "pouco tempo e poucos recursos materiais dispunha para atender aos interesses privados da Província" (FREITAS, 1985, p.33). Nessa seca, todos os chafarizes da cidade secaram, ficando os aguadeiros responsáveis pelo abastecimento de água de São Paulo. Dessa forma, a cidade continuou a ser abastecida por chafarizes e sua precária rede de $\operatorname{condutos}^{166}$.

164. Relatório à Assembléia Legislativa Provincial pelo presidente (Francisco Ignacio Marcondes Homem de Mello), Typografia Imparcial de J. R de Azevedo Marques, 1864 .

165. FREITAS, Affonso A. de Freitas. Tradições e Reminiscências Paulistanas. São Paulo: Itatiaia/Edusp, 1985 , p.32.

166. "A freguesia da Sé era abastecida pelas nascentes do Anhangabaú, captadas no tanque de Santa Teresa (situado na parte mais baixa da atual rua Santa Madalena) e aduzidas para a Caixa d'Água da rua Cruz Preta (depois rua do Príncipe e atual Quintino Bocaiuva), construída em 1860; para o chafariz do largo da Misericórdia, construído e inaugurado em 1792 por ordem do capitão general Bernardo José de Lorena e para os largos do Pelourinho (depois largo 7 de Setembro), de S. Gonçalo (presentemente praça dr. João Mendes), de S. Francisco e de S. Bento, mandados construir em 1864 pelo presidente dr. Homem de Mello. O chafariz do Campo da Luz (Hoje transformado em Avenida Tiradentes) e o do Piques derivavam-se do encanamento geral das águas do 
A precariedade da rede de distribuição continuava a comprometer o acesso dos moradores à água. A distribuição de água de São Paulo, na década de 1860 , era uma rede mista onde $80 \%$ da água consumida pelos moradores não era proveniente dos chafarizes da vila mas sim, de cisternas, da coleta direta em rios e da venda de água pelos aguadeiros ${ }^{167}$.

O problema de abastecimento se agravava e em 1866, a falta de água nos chafarizes da cidade provocou revoltas violentas. Quanto ao esgotamento e a higiene pública, segundo Affonso de Freitas, "se já era nascida, estaria ainda na primeira infância” (FREITAS, 1985).

No relatório apresentado à Assembleia Legislativa Provincial em 1872, o presidente da província José Fernandes da Costa Pereira, esclarece a situação do abastecimento em São Paulo e aponta para a adoção do sistema de captação das águas da Cantareira:

"Não há regularidade na edificação das casas [paulistas]; menos há um sistema de esgotos que obste constantes exalações miasmáticas. Falta-lhes até o abastecimento de água potável,

tanque do Bexiga para o Jardim Público, serviço esse inaugurado em 1868 e que não teve a duração de um decênio, porquanto, já em 1876, os dois chafarizes achavam-se desmantelados e o leito do lago central do jardim, completamente enxuto, servia de hangar ao aeronauta Ceballos. E nem se deveria esperar maior durabilidade de semelhante abastecimento, considerando que os tubos nele empregados eram manufaturados em papelão revestido de asfalto e, embora tivessem tido "tão bem assentados que não havia uma junta por onde a água saísse" contudo o líquido, segundo assevera o inspetor geral das obras públicas em seu relatório entregue a 30 de janeiro de 1869 ao Barão de Itaúna, então presidente da Província, "rompia o chamado betume no espaço médio entre o tubo e os cabeços de ferro, devido à imperfeição e pouca vigilância empregada na oficina, estabelecida na antiga casa dos loucos (situada na rua de S. João)." (FREITAS, 1985, p.32)

167. "Todos esses chafarizes e mais a bica de Baixo, localizada entre as ruas de Baixo (hoje Carlos Gomes), e a do Meio (atual Rodrigo Silva) aduzida do extremo do largo da Forca (presentemente Largo da Liberdade), através de uma galeria subterrânea e as do Gaio, dos Ingleses e do Moringuinho, forneciam à população da Capital cerca de 336.000 litros ou, empregando a tecnologia da época, 20.000 medidas de água; as restantes 80.000 que faltavam para completar o abastecimento em 24 horas, pelos entendidos calculado em 100.000 medidas, eram retiradas de cisternas abertas ao longo das margens do rio Tamanduateí e do córrego Lavapés e vendidas em pipas ambulantes ao preço de 40 réis o barril. Sem embargo desse sistema misto ou, talvez, por isso mesmo, o abastecimento de água à Paulicéia, por sua natureza deficiente, tornava-se precário sempre que a Providência Divina descuidava-se de fornecer o óxido vital em forma de copiosas chuvas." (FREITAS, 1985, p.33) 
uma das condições essenciais de salubridade. [...] Como sabeis a lei provincial $n^{\circ} 102$ de 1870 , autorizou [...] o encanamento das águas da cantareira [...] podendo para esse fim contrair empréstimo ou emitir títulos até a quantia de 650 contos, com o juro de $7 \%$ ao ano [...]. Nesse sentido [foram chamados] concorrentes que se encarregassem da obra, segundo um plano organizado pelo eng. Brunlees." ${ }^{68}$

Diante da situação da distribuição de água e salubridade, o presidente, portanto, assume a incapacidade do Estado de realizar as obras necessárias para a instalação das redes. Conclui-se, portanto, que o Estado não estava aparelhado tanto economicamente como tecnicamente.

No relatório de 1873 à Assembleia, o presidente João Theodoro discute as propostas para os empreendimentos:

“Tenho recebido algumas [propostas] [...], entendo porém, que nas concessões de privilégios deve o legislador evitar, entre outros, três perigos capitais: (a) garantia de juros - a situação atual da província não permite, e os transcendentes interesses das companhias de linhas férreas a tornam presentemente inexequível; (b) transmissibilidade de privilégio - é uma cláusula que revela um pensamento e uma empresa puramente de mercenários e não de utilidade pública; (c) retribuição obrigatória pelos particulares - será uma opressão mais e uma tirania, muitas vezes, contra a pobreza, a mais numerosa classe da capital." ${ }^{169}$

Posteriormente, em 1875, a Assembleia Legislativa Provincial aprova a lei $n^{\circ} 45$, que determina a instalação obrigatória de um sistema completo de "despejos e esgotos" nos prédios da capital. No entanto a obrigatoriedade de instalação de água não foi aprovada. Mesmo assim, o projeto de captação de água na Cantareira começou a se viabilizar com a associação de três importantes personagens da época: o engenheiro inglês Daniel Mackinson Fox, o major Benedito Antonio da Silva e coronel Antonio Proost Rodovalho, quando estabeleceram, com o Governo Pro-

168. Relatório à Assembléia Legislativa Provincial pelo presidente (José Fernandes da Costa Pereira Jr.), Tipografia Americana, São Paulo, 1872.

169. Relatório à Assembléia Legislativa Provincial pelo presidente (João Theodoro Xavier), Tipografia Americana, São Paulo, 1873. 
vincial, um contrato de concessão do monopólio da exploração da rede de esgotos de São Paulo, com validade de setenta anos, a partir da instalação de um "sistema completo de esgoto e despejos" (OSEKI, 1992). Inicialmente, esse contrato, além da rede de despejos e esgotos, determinava a construção de seis chafarizes ${ }^{170}$ e de diversas válvulas de combate a incêndio na cidade.

Finalmente, em 1877, os três empreendedores fundaram a Companhia Cantareira de Águas e Esgotos ${ }^{171}$. Para a assinatura do contrato de concessão, foi alterada uma cláusula, propondo que a Companhia, além da instalação da rede de esgotos, como determinava inicialmente a concessão, também supriria de água todo o perímetro urbano da cidade. Nesse momento, a área central da cidade tinha aproximadamente 191 $\mathrm{km}^{2}$. (SANT'ANNA, 2007)

Os proprietários da Companhia estavam envolvidos com o capital cafeeiro, o que determinou que o negócio respeitaria os interesses desse setor da economia. Para a realização da obra seriam contratados engenheiros ingleses. Tratava-se de uma companhia privada brasileira, ligada ao capital cafeeiro mas também com a participação de profissionais ingleses (SANT'ANNA, 2007 e OSEKI, 1992). Tanto o major Benedito Antonio da Silva ${ }^{172}$ quanto o coronel Antonio Proost Rodovalho ${ }^{173}$

170. Segundo Denise Bernuzzi de Sant'Anna, "os chafarizes deveriam ser colocados em largos, nos seguintes locais: Brás, Luz, Guaianases, Curros, Sete de Setembro e São Bento." SANT'ANNA, Denise Bernuzzi. Cidade das Águas: usos de rios, córregos, bicas e chafarizes em São Paulo (1822-1901). São Paulo: Editora Senac, 2007, p.168, nota 3 .

171. Inicialmente a Companhia foi dirigida por Clemente Falcão de Sousa Filho, o Barão de Três Rios e por Rafael Aguiar Pais de Barros. (SANT’ANNA, 2007)

172. O major Benedito Antônio da Silva foi comandante da guarda nacional de Santo Amaro, acumulou durante a sua vida uma das maiores fortunas da segunda metade do século XIX. Foi fundador, além de alguns bancos paulistas, da Companhia Docas de Santos, da Companhia de Águas São Lourenço e da Ferrovia Rio Claro-São Carlos. Residia em uma casa no Páteo do Colégio, localizada ao lado do Solar da Marquesa de Santos. Foi membro da Irmandade da Santa Casa de Misericórdia de São Paulo, instituição conhecida por ser uma das grandes proprietárias de terras em São Paulo atualmente. CINTRA, Jorge P. Primeiras Plantas Topográficas da Cidade de São Paulo. in IDOETA, Irineu; IDOETA, Ivan V.; CINTRA, Jorge P. São Paulo vista do alto, 75 anos de aerofotogrametria. São Paulo: Érica, 2004.

173. O coronel Antônio Proost Rodovalho, foi membro da Guarda Nacional, promovido a coronel após a campanha da Guerra do Paraguai. Ao longo do século XIX atuou como empresário nos setores do açúcar, sal e café sendo fundador do Banco Comercial de São Paulo, da Caixa Econômica e Monte de Socorro, da 
tinham envolvimento com o capital bancário, industrial e comercial. Foram responsáveis por financiar e empreender diversos negócios em São Paulo e na província, sempre ligados à provisão de infraestrutura, como a exploração de gás, água, cimento e a instalação de ferrovias. Exerciam forte influência política nas decisões da Câmara e da província, tendo sido o coronel, membro da Câmara e presidente dessa instituição entre 1866 e 1870 . Ou seja, além do poder econômico, governavam e legislavam. Ambos eram proprietários de terras na cidade, muitas das quais situavam-se dentro da área do antigo rocio e nas várzeas dos rios. Esse é o caso da chácara do Capão, de propriedade do major Benedito Antonio da Silva e que receberia, nesse mesmo período, os loteamentos que deram origem à avenida Paulista e bairros próximos. A chácara do Capão foi uma das maiores que existiu dentro do limite do antigo rocio, como pode ser observado no mapa das chácaras, páginas 154-155, número 39 na indicação do mapa e da legenda. Evidentemente, Silva e Rodovalho apoiaram a abolição da escravatura e a imigração europeia.

Dessa forma, o capital cafeeiro, que nesse período era controlado por apenas algumas famílias, começava também a ser aplicado em empreendimentos de serviços públicos urbanos, concentrando essas atividades.

O engenheiro Daniel M. Fox, dentre diversas atividades que envolviam a instalação de infraestruturas, havia coordenado, contratado pela São Paulo Railway, os complexos trabalhos para a instalação da ferrovia Santos-Jundiaí, construída de 1860 a 1867, projeto que também contou com a participação de James Brunlees.

Em 1878, a Companhia contratou, em Londres, o engenheiro Henry Batson Joyner para coordenar as obras e realizar uma planta cadas-

Companhia de Estradas de Ferro Ituana, da Companhia de Estradas de Ferro São Paulo-Rio de Janeiro e da Companhia Ítalo Paulista. Também financiou e participou dos empreendimentos como a Fábrica de Tecidos Anhaia \& Cia, a Serraria Sydow e a Companhia de Gás de São Paulo. Em Caieiras, no interior da província, o coronel empreendeu um negócio de exploração de cimento e papel, a Companhia Melhoramentos de São Paulo. Foi fundador da Associação Comercial de São Paulo. Membro do Partido Conservador, era abolicionista e é considerado um dos primeiros apoiadores da República. Assim como o major Silva, foi membro da Irmandade da Santa Casa de Misericórdia de São Paulo. CINTRA, Jorge P. Primeiras Plantas Topográficas da Cidade de São Paulo. in IDOETA, Irineu; IDOETA, Ivan V.; CINTRA, Jorge P. São Paulo vista do alto, 75 anos de aerofotogrametria. São Paulo: Érica, 2004. 
tral ${ }^{174}$ da cidade de São Paulo - ver mapa das páginas 146-147. Após alguma dificuldade com a chamada de capitais, os trabalhos se iniciaram nesse mesmo ano com as obras do reservatório da Consolação, situado em uma parte das terras do major Benedito Antônio da Silva, na chácara do Capão. Tanto o reservatório como a planta foram concluídas em 1881 .

Sobre essa planta, apesar de se tratar de uma planta cadastral, minuciosamente levantada e desenhada, não foi útil para resolver as questões que envolviam a determinação dos domínios de terras municipais e privadas do rocio, visto que representava exclusivamente a área urbanizada da cidade. Curiosamente, como explica Eudes Campos ${ }^{175}$, ela foi utilizada na Câmara de São Paulo para complementação de dados:

"Em 7 de março de 1881, um vereador indicou à Câmara que solicitasse da empresa cópia desse documento gráfico para que fosse realizado a partir dela um trabalho de complementação de dados que interessava à Municipalidade. Como a Câmara não conseguia mandar realizar a tão sonhada planta cadastral da cidade, que orientasse a distribuição das terras do patrimônio municipal (rossio) sob a forma de datas e todos os futuros

174. Inicialmente a Companhia foi dirigida por Joaquim Egídio de Souza Aranha, o então Barão de Três Rios, Clemente Falcão de Sousa Filho e por Rafael Aguiar Pais de Barros. (SANT'ANNA, 2007) O cafeicultor Joaquim de Souza Aranha barão, visconde, conde e marquês de Três Rios - era proprietário da chácara do Bom Retiro que fazia parte do antigo rocio de São Paulo na várzea do Tietê próximo á foz do Tamanduateí. Diversas vezes deputado provincial, ocupou a presidência da Província em três ocasiões, dezembro de 1878 a fevereiro de 1879 , de março a abril de 1881 , e de novembro de 1881 a janeiro de 1882 . Produziu café em fazendas de Campinas e Rio Claro. Sousa Filho tinha sido presidente da Companhia Paulista de Estradas de Ferro na década de 6o. Pais de Barros (não confundir com seu primo Rafael Tobias de Aguiar Pais de Barros, o segundo barão de Piracicaba) estudou na Faculdade de Direito do Largo São Francisco e era cafeicultor, proprietário da Fazenda São Rafael na cidade de Leme, São Paulo. Foi vereador em São Paulo durante o Império e signatário da Convenção de Itu em 1873 e, assim, apoiador da República, da abolição da escravatura e da imigração. Também foi provedor da Santa Casa de Misericórdia de São Paulo. Tornou-se proprietário de uma enorme chácara que incorporava terras do antigo rocio, às margens do Tamanduateí, o sítio do Pinheiro, que pode ser vista no mapa das chácaras (ver páginas 154-155, número 28 da indicação do mapa e da legenda). Mesmo sendo proprietário do sítio do Pinheiro, Pais de Barros morava em uma casa na rua Alegre, atual rua Brigadeiro Tobias, nome dado em homenagem ao seu primo.

175. CAMPOS, Eudes. São Paulo Antigo: Plantas da Cidade. Informativo Arquivo Histórico Municipal, 4 (20): set/out. 2008. 
trabalhos de alinhamento de ruas e de construções, o edil cogitava usar essa planta recentemente executada pela iniciativa privada e adaptá-la ao serviço público. Ainda em 1887 a planta da Cantareira era vista na Câmara como um documento muito útil, por trazer uma parte do cadastro da cidade e parte dos arrabaldes. Embora já desatualizado no que se refere ao traçado viário e às construções, em decorrência da rápida expansão urbana experimentada naqueles dias, mantinha-se esse trabalho "digno de toda a confiança"." (CAMPOS, 2008)

Vale ressaltar que, como se viu, os personagens envolvidos na organização municipal e provincial, nas empresas de serviços urbanos e nas privatizações de terras e águas eram exatamente os mesmos, fato que explica o trânsito dessa planta e explicita a relação contraditória entre a privatização do rocio, o capital industrial e comercial, a provisão de infraestruturas urbanas e o próprio Estado ${ }^{176}$.

Ainda sobre a planta de 1881, é notável sua objetividade ${ }^{177}$ quando comparada com plantas anteriores, registrando inclusive mudanças de nomes ${ }^{178}$ de diversas localidades como decorrência direta de um movi-

176. Segundo Jorge Oseki, “o grande capital cafeeiro, aliás constituído na época por oito grandes famílias paulistas, tem grandes fazendas, ações de empresas ferroviárias, fomenta a imigração, empreende serviços públicos urbanos, possui bancos, dedica-se à atividade industrial. E também governa." (OSEKI, 1992, p.17)

177. "Ainda sobre os registros notáveis na planta da Companhia Cantareira, vê-se que se trata de uma representação extremamente objetiva e redutora, sendo seus edifícios representados de forma muito clara e direta. No mapa da Companhia são representadas igrejas, lojas maçônicas, teatros, a assembléia, quartéis, academias, armazéns e estações, não havendo preferência, ao menos graficamente, por edifícios civis, militares ou religiosos. O caráter laico desse mapa não é somente uma característica de uma planta realizada por uma empresa capitalista de provimentos urbanos, a quem esse comportamento beneficiaria, mas também uma evidência da laicização crescente na transição do Império para a República, quando diversos aspectos da vida social acompanharam essa tendência, influindo notavelmente, inclusive, na nomeação de logradouros" (GOUVÊA, 2010).

178. "Até mesmo nomes novos de ruas haviam sido adotados oficialmente em 1865 , ficando as tradicionais denominações populares, às vezes tão cruas, substituídas por nomes mais "convenientes", relativos a pessoas ilustres ou então alusivos a fatos e datas comemorativas da história pátria. Os principais edifícios da Capital continuavam sendo igrejas e conventos, mas agora vemos também assinalados sedes de jornais, tipografias, boticas e colégios, o que demonstra que a cidadezinha começava a ter uma vida urbana mais intensa" (CAMPOS, 
mento de laicização ${ }^{179}$ decorrente da República. Nela, além da ferrovia, a localização de diversos pontos comerciais evidencia uma maior diversificação de atividades urbanas e a forte tendência de crescimento da atividade comercial e industrial na cidade. Apesar de serem o foco principal da representação, a água e os rios não aparecem como tal, já que a intenção aqui é o fornecimento do serviço de água e esgoto.

O engenheiro Adolfo Augusto Pinto, que exercia o cargo de fiscal na Companhia, já nesses primeiros anos da empresa, defendia a obrigatoriedade da canalização de água e esgoto para todas as residências da cidade assim como o pagamento regular pelo consumo desses serviços. Pinto tinha excelentes relações com o Governo Provincial ${ }^{180}$.

No relatório à Assembleia de 1880 , o presidente da Província Laurindo Abelardo de Brito, relata:

"S.S.M.M. Imperiais em setembro de 1878 [inauguraram] solenemente os trabalhos do reservatório de distribuição de águas na Consolação, onde se colocou a pedra fundamental. [...] Os trabalhos estão sendo feitos com bastante morosidade [...]. O volume água obtida na Cantareira [será] de 2.970.007 1. que distribuídos por uma população de 30.870 hab. [...] dará a quantidade de 96 1./hab. por dia; quantidade esta [...] muito abaixo dos misteres domésticos [cujo] limíte mínimo é 100 l./ hab./dia [...]. A Cia. já encomendou todo o seu material da Inglaterra [...], chegaram 45 t. de chumbo para as juntas de tubos, $1 / 2$ de estopa para o mesmo fim, 750 barris de cimento, 3180 tubos para o encanamento com $0.305 \mathrm{~m}$ de diâmetro. $\mathrm{O}$ peso total de ferro recebido é de 1,137 t., 6 quintais, 2 arrobas e 3

2008).

179. Sobre a laicização e renomeação das localidades na Europa do século XII, Henri Lefebvre, na análise que fez sobre a consolidação do espaço abstrato lembra que "O espaço que emerge no século XII na Europa ocidental, que gradualmente ganha (a França, a Inglaterra, a Holanda e a Itália), é o espaço da acumulação, seu berço, seu lugar de nascimento. Por que e como? Porque o espaço laicizado resulta da ressurreição do Logos e do Cosmos, que subordinam a si o "mundo" e às forças subterrâneas. Com o Logos e a lógica, o direito se reconstitui; as relações contratuais (estipuladas) substituem os costumes e exigências costumeiras" (LEFEBVRE, 2006, p. 177).

180. Na ocasião, o engenheiro havia sido "muito bem recomendado" pela esposa de Alexandre Vieira de Carvalho, a Condessa de Lajes", sendo que após o trabalho na Cantareira exerceu o cargo de fiscal na São Paulo Railway. (SANT'ANNA, 2007, p.169) 
libras [1.154.492 kg]. As plantas e perfis que da construção para o abastecimento de água, quer para os esgotos, estão prontas e rubricadas pela Cia.e pelos empresários." ${ }^{181}$

Em meio a questionamentos sobre a lisura do empreendimento, as obras continuaram e, até 1881, os chafarizes constantes do contrato foram instalados e nesse mesmo ano as águas da Cantareira passaram a ser levadas ao reservatório da Consolação e distribuídas para apenas parte da cidade (SANT'ANNA, 2007). Isso não aconteceu sem protestos:

"Há coisas que a natureza dá de graça e de que ninguém tem o direito de se apoderar para vender ou alienar. São água, luz e ar. A Companhia Cantareira obteve o privilégio de encanar a água da Cantareira: mas ninguém podia dar a água, porque ela é de todos. Não entendeu porém assim a privilegiada: entendeu que o privilégio lhe dava a posse da água também, e fazendo desta posse base de suas operações nos vai vendendo aos litros a água que é nossa. A Companhia adquiriu com o privilégio o aluguel do encanamento pelo preço que ela quiser: mas não a propriedade da água." ${ }^{82}$

Ao longo da década de 80 , diversas chácaras foram loteadas na região do reservatório provocando uma rápida ocupação da região da Consolação e rua Augusta. Nessa época, a chácara do Capão, propriedade do major Benedito Antonio da Silva, também foi loteada e a avenida Paulista foi aberta. A instalação da rede de água significava o aumento do interesse por morar nessas localidades, favorecendo a atividade imobiliária.

Em 1882 a Companhia iniciou a cobrança de taxas de consumo de parte das casas servidas pela rede que, até 1888, teria cerca de 5.000 domicílios conectados. (SANT'ANNA, 2007).

Segundo o relatório apresentado à Assembleia em 1882 pelo presidente Joaquim Egídio de Souza Aranha, barão de Três Rios, também dirigente da Companhia,

$$
\text { “[...] a Cia. [...] tem encontrado dificuldades sérias na chamada }
$$

181. Relatório à Assembléia Legislativa Provincial pelo presidente (Laurindo Abelardo de Brito), Tipografia do Diário de Santos, Santos, 1880 apud OSEKI, 1992.

182. Correio Paulistano, 26 de abril de 1882, p.3 apud SANT'ANNA, 2007, p.171. 
de capitais [...]. O capital tem sido realizado sobre um número de ações que está muito longe de atingir ao número primitivamente subscrito. A Cia. teve de recorrer a outra fonte de recursos para não interromper os seus trabalhos. Levantou um empréstimo na praça de Londres, na importância de 1.200 contos [...]. As obras conquanto sem dificuldades técnicas a vencer, [...] abonam o zelo da Cia. [...] Estarão concluídas dentro de pouco tempo. [...] [As obras de esgoto] infelizmente não tem tido o mesmo impulso." ${ }^{183}$

A rede de esgotos fica pronta em 1883, tornando São Paulo a terceira cidade do Brasil com um sistema completo de esgoto sanitário. No Rio de Janeiro, obra similar foi concluída em 1864, antes de Berlim em 1874, Buenos Aires em 1877 e Roma em 1879. Recife teve tais instalações a partir de 1878. Paris teve seu sistema instalado em 1855. Cidades americanas foram as primeiras a ter uma rede de esgotamento, Brooklyn em 1855, Chicago em 1856 e Jersey city em 1859. Na Alemanha, Frankfurt em 1867, Stuttgart e Nuremberg em 1874 e Colônia e Munique em 1881. (OSEKI, 1992) Esses dados revelam a sincronia em que essas atividades aconteciam no mundo, provando que a economia atrelava-se, cada vez mais, a condições mundiais de reprodução de capital, ainda que São Paulo fosse muito menor e menos estruturada que essas outras cidades.

A rede de esgotos de São Paulo era um sistema americano de circulação contínua. Uma estrutura muito simples, baseada em um coletor geral feito de ferro fundido de 48 polegadas posicionado na várzea da Luz até o Tietê. As ramificações da rede eram compostas por tubos de menor diâmetro paralelos aos rios principais, como era o caso do Anhangabaú e do Tamanduateí. Coletores secundários derivavam desses principais, pelos quais se espalhavam por todas as ruas da cidade, feitos de manilhas de barro vidrado de 18, 15 e 12 polegadas. O despejo do material coletado era realizado in natura no rio Tietê sem desinfecção prévia. Nesse momento, esse despejo não significava um problema para o Tietê, já que a proporção dos resíduos em relação à água era considerada abaixo dos padrões, levando-se em conta que a indústria de São Paulo ainda era muito pouco desenvolvida. (OSEKI, 1992)

183. Relatório à Assembléia Legislativa Provincial pelo presidente (Conde de Três Rios). Apresentado pelo quarto-vice (Manuel Marcondes Moura e Costa), Tipografia do Diário de Santos, Santos, 1882 apud OSEKI, 1992. 
Apesar de ter diversos problemas e melhorias a fazer, a rede de esgotos de São Paulo construída pela Cantareira era considerada "a melhor do Brasil". Entretanto, segundo Jorge Oseki, essa afirmação é relativa já que a reivindicação popular e maior necessidade era a água e não o esgoto. Evidentemente, um não substitui o outro. Entretanto, é importante notar que nesse mesmo período havia mais casas servidas por esgoto que por água, sendo privilegiada a região mais rica da cidade. Esse fato mostra que a Cantareira estava mais interessada na realização do negócio que propriamente na questão do saneamento. (OSEKI, 1992)

Outro fator importante é que, apesar de a Companhia ser uma empresa nacional, importava da Inglaterra todos os materiais e equipamentos empregados na construção da rede. Somente em 1900 é que manilhas nacionais começam a ser utilizadas no Brasil. Esse fato também reforça uma tendência de internacionalização dos meios de produção, o que, além de prejudicar a nascente indústria nacional, contribuía com a alienação de nossos operários já que "estas mercadorias transpondo o oceano, transformavam-se de fetiches em mistérios [...]. Objetos que nossos trabalhadores vão colocando no chão sem saber muito bem para que serviriam." (OSEKI, 1992)

Segundo Valério Victorino ${ }^{184}$, no momento em que as obras foram concluídas, essa rede era capaz de servir o dobro da população da cidade que era de 30.000 habitantes. Entretanto, o aumento populacional observado nos dez anos seguintes - 120.000 habitantes e 8.642 edifícios em 1892 - tornou obsoleto o sistema muito rapidamente. Os então 3.500.000 litros diários fornecidos pela rede eram considerados irrisórios. (VICTORINO, 2002b)

O fato é que, como o abastecimento de água continuava insuficiente, uma significativa parcela da população continuava a se servir das águas sujas das bicas e chafarizes abastecidas pelos rios próximos. A situação piorava muito nos períodos mais secos do ano e, dessa forma, as revoltas populares continuavam a acontecer. Além disso, esse novo conceito de se relacionar com a água também não agradava a todos. A cobrança sistemática pelos serviços de água e esgoto tornava esses recursos inacessíveis a muitos moradores. Além disso, o antigo serviço prestado pelos aguadeiros permitia alguma negociação no pagamento

184. VICTORINO, Valério Igor. Uma visão Histórica dos Recursos Hídricos na Cidade de São Paulo in Revista Brasileira de Recursos Hídricos, vol. 7. São Paulo: $2002 \mathrm{~b}$. 
que agora não era mais possível.

O serviço de esgoto também se tornou deficitário quando a rede, inaugurada em 1883, era capaz de servir apenas $66 \%$ dos edifícios em 1889 e apenas $48 \%$ já em 1894 .

Longe das condições ideais, os chafarizes e bicas continuavam a ser importantes fontes de água para os moradores de São Paulo. O comportamento da Companhia em relação a esses equipamentos era muito claro. Cumprido o contrato com a instalação de seis chafarizes, a Cantareira iniciou o desmonte da ancestral rede, desmantelando antigos chafarizes e desfazendo as redes de condutos. A intenção era forçar a população a comprar os serviços da Companhia de forma que diversos chafarizes da cidade foram relocados e depois demolidos ${ }^{185}$.

O planejamento da Companhia, quando da implementação da rede, não previu o crescimento da cidade. $\mathrm{O}$ suposto desenvolvimento da rede, previsto no momento de sua instalação, não se mostrou eficiente. À insuficiência da rede uniu-se a má qualidade das águas oferecidas pela Companhia e os jornais passaram a acusar a empresa de ser a responsável pela propagação de surtos e contaminações.

A incapacidade da Companhia de suprir satisfatoriamente a popu-

185. Os tanques Municipal e de Santa Teresa, formados a partir das nascentes do Anhangabaú foram desativados por volta de 1881 pela Cantareira. O chafariz do largo São Francisco desapareceu em 1876. Existente desde fins do século XVIII, a bica do Gaio foi removida em 1887. O chafariz do Piques, construído em 1815, já não existia no final da década de 1870. A fonte que alimentava a bica dos Ingleses, utilizada desde muito cedo em São Paulo, desapareceu na década de 1890 assim como a bica de Baixo. O chafariz do largo da Pólvora, existente desde a década de 1820 foi removido por volta de 1880 . O tanque do Zúniga foi secado e terraplanado em 1855 e o chafariz desapareceu em 1881. O chafariz do largo do Brás foi desmontado em 1893, pela Repartição de Águas e Esgotos. O chafariz do Miguel Carlos, existente desde o final do século XVIII foi desativado em 1881. Os chafarizes do Campo da Luz, existentes desde 1863, desapareceram por volta de 1893, a partir da encampação da Cantareira, assim como os chafarizes dos largos de São Bento e do Pelourinho. O chafariz do largo do Palácio foi demolido na década de 1890 . O chafariz do largo do Rosário foi demolido em 1893 pela Repartição, assim como o chafariz do largo do Carmo, inaugurado em 1875. O chafariz do largo dos Guaianases, construído pela Companhia em 1881, foi demolido pela Repartição em 1893, assim como o chafariz da Praça da República. O chafariz da praça do Mercado, foi construído em 1882 e demolido em 1893, também pela Repartição. As poucas bicas e chafarizes que resistiram à Companhia e à Repartição já estavam com as águas sujas a partir do final do século XIX, sendo demolidas até a década de 1920, após exames de laboratório que atestaram sua contaminação. (GASPAR, 1970) 
lação da cidade fez com que a empresa se endividasse e muito rapidamente se reconheceu a sua impotência diante dos problemas de abastecimento.

Em 1893, o Estado promoveu a encampação da Companhia ${ }^{186}$, absorvendo as atividades da empresa mediante pagamento de uma indenização ${ }^{187}$ aos proprietários da Cantareira. $O$ ato de encampação criou a Repartição de Águas e Esgotos - RAE, sob a direção do engenheiro José Pereira Rebouças. Nesse mesmo ano, a Repartição promoveu a ampliação da rede de distribuição de água com a captação nos córregos do Bispo, Iraguaçu e Meninos, que passaram a alimentar a adutora do Guaraú. A rede de esgotos também foi melhorada, expandida a toda a área povoada, com uma extensa e profunda galeria de drenagem construída em diversos pontos, até os extremos da cidade.

A Repartição, assim como a Companhia, continuou com o desmonte e demolição de chafarizes. A atuação da Companhia e da Repartição representou o fim da oferta de água gratuita à população da cidade de São Paulo. Os desmontes aconteciam mesmo com a efetiva diminuição dos domicílios servidos e, dessa forma, devido à importância desses equipamentos, após as demolições aconteciam rebeliões, como foi o caso da remoção do chafariz do largo do Rosário em 1893.

Enquanto isso, a RAE promoveu a captação da água dos córregos

186. "Flávio Saes descreve no começo do século a transferência da estrada de ferro Sorocabana, uma companhia privada, à União, sua principal credora, já que esta companhia estava insolvente. Posteriormente essa mesma companhia é arrematada (em 1907) a um grupo franco-norte-americano (a "Sorocabana Railway Co. Ltd.") pela necessidade de se obterem recursos para sustentar compras de café. Arrendou-se então um ativo do Estado por 60 anos, o que representou quase a sua alienação. Em 1921 a Sorocabana volta a ser administrada pelo Governo do Estado de São Paulo (mediante um pagamento de uma multa por rescisão de contrato de cerca de 50.000 contos), não "[para se constituir] como empresa estatal, portanto com certa autonomia, mas sim como uma "repartição" já que todas as suas receitas ao Tesouro do Estado e todas as suas despesas ficavam a cargo do tesouro". Imaginamos que a encampação da Cia. Cantareira e sua transformação em Repartição de Águas e Esgotos tenha sido análoga, isto é, com perda total de sua autonomia financeira." (OSEKI, 1892. p.28)

187. Segundo Denise Bernuzzi de Sant'Anna, os engenheiros Adolfo Pinto e Francisco de Sales Oliveira foram os responsáveis por arbitrar o preço da encampação. "Os dois engenheiros estimaram em 6.814:549\$663 (seis mil oitocentos e catorze contos, quinhentos e quarenta e nove mil seiscentos de sessenta e três réis) o quantum da indenização à ser paga pelo Estado à referida Companhia pela encampação de seus serviços e direitos. PINTO, Adolfo Augusto. Minha Vida apud SANT'ANNA, $200 \%$ 
Simão e Borba, na cabeceira do Ipiranga, assim como nos córregos Cassununga, Capão Redondo e Engordador, do leste da Cantareira. O reservatório da Consolação foi ampliado e outro foi construído no Paraíso. Como apoio a essas obras foi construída a linha do Tramway da Cantareira, que ligava a serra ao Pari, onde ficava o pátio da São Paulo Railway e por onde chegavam os materiais que continuaram a ser importados da Inglaterra.

As obras de retificação do Tamanduateí, do Ipiranga até o Tietê, prosseguiram, assim como as do Tietê na região do Anastácio. Nesse período, o Anhangabaú também foi canalizado e coberto.

Com relação à rede de esgoto, em dois anos (1893 e 1894) o Estado estendeu a rede a 3.410 edifícios, enquanto que a Companhia, em dez anos (1883 a 1892), construíra uma rede para servir apenas 6.244 edifícios. Mesmo com observável aumento na eficiência dos serviços prestados pelo Estado, com o crescimento da população, que quadruplicou entre 1890 e 1900, o fornecimento de água mantenha-se deficitário.

Sobre a mão de obra utilizada na construção das redes de água e esgoto da Companhia Cantareira e da Repartição, pouco foi registrado. Os estudos de Paulo Cesar Xavier Pereira sobre os fundamentos da industrialização da construção revelam que seu estabelecimento se deu na virada do século com o assalariamento do trabalho, portanto, a partir do estabelecimento de um mercado de trabalho constituído pela propriedade da terra e a consolidação do mercado fundiário e imobiliário. Assim como vimos, isso aconteceu a partir da inserção e sujeição do trabalhador nacional alforriado (escravo de aluguel e escravo assalariado) e do trabalhador livre imigrante. (PEREIRA, 1988)

$\mathrm{Na}$ cidade de São Paulo, a presença de escravos não era expressiva e, a partir da década de 1870 , aumentou o número de trabalhadores livres no mercado de trabalho da construção. No início, no mercado de trabalho da construção, deu-se preferência ao trabalhador italiano, pela qualidade do seu trabalho, cuja participação na proporção de trabalhadores livres aumentou até o início do século XX. O início do século foi marcado por reivindicações e paralisações empreendidas pelo movimento operário, conseguindo feitos importantes como a redução da jornada de trabalho na construção civil. Essas paralisações geraram conflitos que acabaram transformando a imagem que se tinha do trabalhador italiano que, resistindo à exploração, passou a ser um trabalhador indesejável. As paralisações passaram a ser duramente reprimidas e as condições de 
trabalho pioraram diante da aceitação de outros trabalhadores do rebaixamento de salários, abrindo espaço para a ampliação da espoliação do trabalhador da construção. (PEREIRA, 1988) Esse era o contexto da atividade de construção.

Jorge Oseki, ao estudar o "trabalhador de obras públicas" em São Paulo nesse mesmo período, se deparou com a quase inexistência de fontes documentais que registrassem o trabalho de construção de redes de infraestrutura, sobretudo nas obras das redes de água e esgoto da Companhia Cantareira e da Repartição de Águas e Esgotos. Os poucos dados encontrados permitiram fazer algumas observações. A partir de dados do recenseamento de 1872 , percebe-se que os trabalhadores de obras públicas eram muito poucos se comparados aos trabalhadores de "edificações". No grupo de obras públicas, registrou-se a presença de trabalhadores nacionais brancos, negros e estrangeiros, com o predomínio de nacionais brancos e muito pouca participação de trabalhadores escravos negros. Apesar de os dados serem pouco esclarecedores, Oseki conclui que "ou as tarefas não estavam definidas enquanto habilitação profissional ou o trabalho utilizado era basicamente bruto, não qualificado nem registrado. Um trabalho totalmente indiscriminado." (OSEKI, 1992, p.127)

CHICAGO, BUENOS AIRES, RIO DE JANEIRO, PARIS, LONDRES, BERLIN E MADRID

Em São Paulo, o Código de Posturas de 1875, que foi revisto e ampliado em 1886, passando a controlar mais a rua, lugar de intensa sociabilidade, do cotidiano nos largos, em torno dos chafarizes, lugar da escravaria, da libertinagem e da devassidão. $O$ espaço público foi redimensionado para receber o capital cafeeiro, intervindo, basicamente, nos bairros pobres e da classe trabalhadora.

A "higiene" apareceu na cidade no momento em que esse tema dominava completamente o debate urbanístico internacional, a partir da atuação da engenharia. Em São Paulo, a população passava de 64.934 em 1890 para 120.775 de habitantes em 1893. Isso também motivou tais intervenções, que acabaram por produzir os subúrbios da cidade, agora marcadamente populares e operários.

Evidentemente, a preocupação com a salubridade das ocupações populares não eram puramente humanistas, como fica claro na declara- 
ção de Cerqueira César, então vice-presidente da Província:

"Epidemias intensas devastaram durante os últimos meses várias localidades do Estado. [...] As epidemias que assolam o principal dos nossos portos não só perturbam o mecanismo econômico do Estado e ameaçam de sérias dificuldades a sua comunicação comercial com o exterior, mas expõe também todo o território paulista à invasão da febre amarela, dizimando a classe operária e roubando-nos braços úteis que importamos com sacrificios." 188

Coube ao Governo Provincial, que encabeçava os esforços de implantar a mão de obra assalariada com a promoção da imigração europeia, criar em 1890 o Serviço Sanitário e em 1894 o primeiro Código Sanitário do Estado de São Paulo. A fala do vice-presidente da província evidencia a relação entre a constituição das redes de infraestrutura de água e esgotos com os interesses do capital cafeeiro e industrial, no momento em que se instituía o mercado de trabalho assalariado na cidade. $O$ surgimento da ideologia sanitária não é exclusivo da cidade de São Paulo, ainda que, como vimos, essas redes tenham sido constituídas quase que simultaneamente em diversas cidades do mundo.

Sobre o surgimento das preocupações que deram origem ao sanitarismo, as décadas de 1830 e 1840 destacam-se como as mais importantes na história da engenharia sanitária. As epidemias de cólera que assolaram as cidades inglesas na década de 30 despertaram a preocupação com o saneamento das cidades, evidenciando que as doenças eram mais intensas em áreas urbanas carentes de saneamento efetivo, principalmente por não se limitarem às classes mais baixas da sociedade.

Um dos documentos que mais influenciaram as decisões nesse período foi o relatório sobre doenças da classe trabalhadora inglesa, publicado em 1842 por Edwin Chadwick ${ }^{189}$. Nesse relatório, o sanita-

188. CESAR, Cerqueira. Mensagem dirigida ao Congresso Legislativo do estado pelo vice-presidente do estado em exercício, 7 de abril de 1892 apud ROLNIK, 2003, p. 38 .

189. Edwin Chadwick (1800 - 1890), sanitarista britânico, pioneiro da saúde pública e incansável defensor da higiene, foi um dos primeiros cientistas a compreender a importância do fornecimento de água pura. A Inglaterra estava em pleno desenvolvimento industrial e as condições de higiene precárias, principalmente com o lançamento indiscriminado dos efluentes industriais em córregos e rios. O relatório de 1842 demonstrou a relação entre pobreza e insalu- 
rista inglês constatou a necessidade de se tomar medidas preventivas como drenagem e limpeza das casas, através de um suprimento de água e de esgoto, junto à limpeza de dejetos nocivos das cidades. Além disso, ele determinou que essas operações deveriam ser resolvidas com os recursos do campo da engenharia civil e não no serviço médico. Nesse momento, a Inglaterra passava por um assombroso desenvolvimento industrial, e a perda de operários para epidemias se tornava, sobretudo, um problema econômico.

A evolução dos conhecimentos científicos, principalmente na área de saúde pública, e a difusão em todo o mundo de uma ideologia científico-tecnológica, tornou imprescindível a necessidade de canalizar esgotos em todos os centros urbanos. Isso aconteceu no momento em que esses centros cresciam e suas economias passavam a se basear na produção industrial.

Em todo o mundo a questão sanitária passava a ser um problema para o avanço da industrialização. As ideias e postulações de Chadwick e da engenharia sanitária se disseminaram pelo mundo, como pode ser observado nos exemplos a seguir.

Após uma grave epidemia de cólera e devido ao alto risco de incêndios, a cidade de Chicago criou, em 1851, o seu Conselho Público da Água (Water Board). A rede foi inaugurada em 1856 e, inicialmente, se estendeu aos locais mais suscetíveis a incêndios e proliferação de doenças, localizados no centro da cidade. Chicago passava por um forte crescimento da atividade industrial, o que motivou uma grande imigração, passando de 30.000 habitantes, em 1850, para 112.000, em 1860. No início do século XIX, índios nativos da região foram forçados a vender suas terras a preços muito baixos. Após a instalação da rede de distribuição de água na década de 50, os lotes urbanos por ela servidos experimentaram uma forte valorização, fazendo com que a rede passasse a seguir os eixos de valorização imobiliária. Nessa ocasião o esgoto era despejado diretamente no lago Michigan. ${ }^{190}$

bridade e tornou-se modelo para sanitaristas de várias outras nações. Integrou diversas comissões importantes na saúde pública inglesa estabelecendo, em 1848, com o estabelecimento do Conselho Geral de Saúde.

190. SMITH, Carl. City Water, City Life: Water and the Infrastructure of Ideas in Urbanizing Philadelphia, Boston, and Chicago. University of Chicago Press, 2013. 
Durante a primeira metade do século XIX, a população de Buenos Aires apresentou um sensível crescimento, acompanhando o aumento da atividade comercial em seu porto devido, principalmente, à concentração dos poderes político e militar argentinos na cidade. A população foi de cerca de $40.000 \mathrm{em} 1801$ a cerca de $90.000 \mathrm{em} \mathrm{1855.} \mathrm{No} \mathrm{contexto} \mathrm{do}$ enriquecimento da cidade, as elites portenhas passavam a visar a modernização da cidade e o estabelecimento de alguma racionalidade na organização do espaço urbano. Esse momento do desenvolvimento urbano de Buenos Aires foi marcado pela presença de investimentos de capital inglês, principalmente através de financiamentos para a produção de infraestruturas, como a estrutura portuária e o fornecimento de água.

Os primeiros projetos de abastecimento de água e esgoto foram propostos no final da década de 1820 pelo engenheiro italiano Carlos Enrique Pellegrini, que propunha a utilização das águas do rio da Prata através de um sistema de elevação e armazenamento. O projeto de Pellegrini foi rejeitado, assim como diversos outros planos apresentados ao poder público até o fim da década de 1850 . Basicamente, o debate se dividia entre os que defendiam que as redes deveriam ser um empreendimento privado, e os que defendiam que as redes eram uma responsabilidade do governo. A preocupação do governo era submeter o controle da água, um bem público, à especulação privada. ${ }^{191}$

Apesar do avanço nos debates, a população sentia os efeitos da precariedade do fornecimento de água e esgoto, dependendo da distribuição realizada pelos aguateros e da coleta em poços. Com o crescimento da população e a falta de saneamento, era inevitável que surtos de febre tifoide acontecessem. Apesar disso, divergências políticas entre as elites argentinas e disputas entre as administrações municipal e provincial, retardaram muito o estabelecimento das redes na cidade. Finalmente, em 1867 foi aprovada a lei que autorizava o Banco da Província a financiar a municipalidade para a execução do projeto de fornecimento de água e esgoto para Buenos Aires. A Comisión de Aguas Corrientes, Cloacas y Adoquinados deu parecer favorável ao projeto do engenheiro John Coghlan e as obras se iniciaram em 1868. Entretanto, esse projeto foi implantado apenas parcialmente, privilegiando as zonas mais ricas da cidade além de edifícios governamentais e algumas empresas. Em 1869 a cidade che-

191. RÜCKERT, Fabiano Quadros. Experiências de Saneamento na Cidade de Buenos Aires: dos projetos de Pellegrini a conclusão do Projeto Bateman (18291905). Florianópolis: Revista Esboços, 2013. 
gava a 177.000 habitantes, isto é, praticamente dobrou em 15 anos. Os problemas de saneamento continuavam e em 1871 a cidade passou por uma epidemia de febre amarela sem precedentes na história argentina. (RÜCKERT, 2013)

A cidade passava por um surto de desenvolvimento urbano e populacional devido ao incremento da atividade agroexportadora argentina que, necessariamente, passava pelo seu porto, refletindo em uma forte onda de imigração europeia. No início da década de 1870 o Governo Provincial concedeu ao engenheiro inglês John Fredrick Bateman o direito de coordenar as obras de implantação das redes através de financiamentos estrangeiros. A rede passou a ser utilizada a partir de 1877 , mesmo que não totalmente concluída e mesmo diante de frequentes denúncias sobre a lisura da concessão e conflitos entre as partes envolvidas. Dessa forma, os trabalhos foram paralisados até 1880. (RÜCKERT, 2013) Nos próximos 12 anos, a população passaria de $230.000 \mathrm{em} 1875$ a $430.000 \mathrm{em} 1887$.

Após o fim da guerra civil entre portenhos e o Exército Nacional, Buenos Aires passou a ser a capital do país, sendo que Bateman tornouse Director de las Obras de Salubridad de Buenos Aires. Após vários adiamentos e denúncias de irregularidades sobre a autonomia de Bateman na importação de maquinários, a obra chegou a 1887 sem estar totalmente concluída. Diante desses impasses decidiu-se pelo arrendamento da obra por uma empresa privada, sendo o direito concedido à The Buenos Aires Water Supply and Drainage Company, de propriedade de um grupo de banqueiros ingleses. Após um boicote realizado por proprietários de lotes que futuramente usufruiriam das redes, o governo nacional decidiu, em 1890, pela anulação do contrato de arrendamento. A essa altura, a cidade já havia crescido muito e possuía uma grande periferia, sendo as obras sempre insuficientes para cobrir a área urbanizada. (RÜCKERT, 2013) Ainda que insuficiente diante da demanda, o projeto de Bateman foi concluído apenas em 1905, quando a população de Buenos Aires chegava a 950.000 habitantes.

A geografia das planícies onde a ocupação da cidade do Rio de Janeiro se iniciou no século XVI era marcada pela presença de lagoas e o pelo movimento das marés. Essas lagoas, e também valas e talvegues naturais, recebiam os dejetos dos moradores, concentrando uma grande quantidade de sujeira. Coube à Câmara Municipal assumir o serviço de 
limpeza desses locais. Os esgotos domésticos passaram a ser acondicionados em barricas e despejados por escravos em praias próximas. Diante das péssimas condições sanitárias, já no século XIX, em 1857, o Imperador D. Pedro II autorizou a assinatura do contrato de projeto da rede de esgotamento que deu origem a The Rio de Janeiro City Improvements Company Limited, empresa de capital inglês, responsável pela construção da infraestrutura de esgotamento concluída em 1864. Após a conclusão do projeto original, a empresa atuou na ampliação da rede, operando através de diversos outros contratos até 1947, quando seu contrato foi encerrado. (SILVA, 1988)

O abastecimento de água do Rio de Janeiro, desde sua fundação, enfrentou o fato de as águas próximas ao núcleo serem salobras devido à proximidade do mar. Para isso, desde muito cedo as águas do distante rio Carioca foram usadas para o consumo. $\mathrm{O}$ transporte de água era realizado por índios e escravos e também vendida nos domićlios por aguadeiros. Os conflitos em torno da água apareceram devido à dificuldade de acesso e ao alto custo para sua obtenção no núcleo. Já no século XVII, existia um projeto de captação das águas do rio Carioca feito pelo governo, obra que seria realizada quase um século mais tarde devido a dificuldades financeiras. Dessa forma, em 1723, foi inaugurado o chafariz de Santo Antônio no largo da Carioca. A água que sobrava do chafariz escorria por uma vala até o mar. Devido à precariedade do sistema, que exigia reparos constantes, de 1744 a 1750 foi construído o Aqueduto da Carioca, utilizando mão de obra escrava e uma estrutura de pedra e argamassa. Com o crescimento da cidade, a distribuição de água por chafarizes foi ampliada, aumentando também o número de rios e fontes dos morros próximos envolvidos no abastecimento. Os locais onde se distribuía água eram o centro da sociabilidade da cidade, concentrando diversas atividades de consumo e obtenção de renda e gerando diversos conflitos. No início do século XIX, a valorização da propriedade fundiária promoveu a ocupação de diversos morros por chácaras onde, frenquentemente, estavam fontes de água que abasteciam a cidade, gerando diversos conflitos entre o Estado, proprietários de terra e a população, que sofria com a falta de água, chegando a buscar água em navios aportados na baía. O estado de calamidade por falta de água permaneceu até 1888, quando o Imperador, diante de forte pressão popular, promoveu um concurso público para a realização de obras de abastecimento. $\mathrm{O}$ projeto dos engenheiros Paulo de Frontin e Belfort Roxo foi escolhido e, 
uma semana após o início das obras, foi estabelecido o sistema de distribuição que duraria por muito tempo. (SANTA RITTA, 2009)

As primeiras estruturas de fornecimento de água de Paris, então chamada de Lutèce, foram aquedutos construídos sob o domínio do Império Romano. Com a queda do Império, essas estruturas forma demolidas. Dessa forma, o rio Sena, além de algumas fontes, passaram a ser os principais fornecedores de água para a cidade. Os despejos de esgoto aconteciam diretamente nas ruas, ainda sem pavimentação, até alcançarem os rios da região. No século XIII, grande parte das ruas foi pavimentada, sendo instaladas canaletas no meio das vias por onde o esgoto era coletado. Esse sistema, que é considerado o primeiro sistema de esgotos de Paris, não se mostrou eficiente já que favorecia a proliferação de doenças.

Por volta da metade do século XVI, a população de Paris chegava a 260.000 habitantes e o fornecimento de água e esgoto se tornaram muito deficitários. Sob o reinado de Luis XIV, na segunda metade do século XVII, foi construído na margem direita do rio Sena, um canal lateral de esgotos. Nesse sistema, o rio Bièvre foi usado como canal de esgoto da parte da cidade à esquerda do Sena. Além desse sistema não resolver o problema de esgotamento, o abastecimento de água foi muito negligenciado. A população ainda tinha que recorrer ao Sena, carregando água em baldes para suas residências.

No final do século XVIII, os irmão Périer criaram a Companhia das Águas de Paris. A intenção era viabilizar a construção da rede mediante a cobrança de taxas de usuários privados que desejassem ter suas residências abastecidas. Dessa forma, foi estabelecido o serviço público de fornecimento de água. Já sob o reinado de Napoleão Bonaparte, foi construído o canal de Ourcq, viabilizando a construção de chafarizes em quase todos os bairros da cidade. Além disso, em grande parte das ruas de Paris foram construídas galerias de esgoto centrais visitáveis, melhorando sensivelmente as condições de esgotamento da cidade. Entretanto, a grande quantidade de água fornecida à população por essa rede também foi a responsável pela proliferação de epidemias de cólera e febre tifoide. ${ }^{192}$

No início do século XIX, Paris passou por um forte crescimento da atividade industrial e, consequentemente, a população da cidade foi de

192. BARLES, S. Urban metabolism and river systems: an historical perspective Paris and the Seine, 1790-1970. Hydrology and Earth System Sciences, 2007. 
cerca de 550.000 em 1801 a 1.000 .000 em 1851. A cidade sofria com péssimas condições de salubridade pela plena insuficiência dos sistemas de água e esgoto. As condições de habitação dos trabalhadores também eram péssimas. A maior parte das pessoas vivia em cortiços mal iluminados e ventilados. A esse fato se associava a dificuldade de circulação de pessoas e transporte de mercadorias na cidade devido à inadequação dos arruamentos medievais. A questão central passava a ser a melhoria nos sistemas de esgoto e circulação. (BARLES, 2007)

Em 1855, o prefeito de Paris, barão de Haussmann, e o engenheiro Eugène Belgrand, ordenados pelo imperador Napoleão III, projetam o sistema de suprimento de água e esgotos de Paris, que continua em funcionamento atualmente. Esse sistema separou as redes, tornando independentes o serviços de água e esgoto além de criar uma rede de água potável e outra de água não-potável. Além desses sistemas, foram abertos novos bulevares e avenidas na cidade, melhorando as condições de circulação e foram construídos novos aquedutos, trazendo água de bacias distantes de Paris. (BARLES, 2007)

Até o final do século XVI, a maior parte dos habitantes de Londres utilizavam o rio Tâmisa e seus afluentes, além de algumas fontes, para o abastecimento de água. Conhecida como Great Conduit, a primeira rede de condutos foi construída no início do século XIII utilizando canos de chumbo. Devido à cota de captação de água, a rede, que só funcionava por gravidade, apenas servia algumas partes da cidade. Aos londrinos mais ricos eram concedidas permissões para a captação da água diretamente de derivações do Great Conduit restando aos mais pobres a coleta de água diretamente no Tâmisa. No início do século XVII, por uma iniciativa de uma empresa privada, foi construída uma rede de captação de água em Hertford, conhecida como New River, a cerca de 60 kilometros de Londres. ${ }^{193}$

No momento em que Londres já contava com cerca de 500.000 habitantes, um grande incêndio, em 1666, destruiu a cidade e seu antigo sistema de distribuição de água, marcando o início de uma nova fase na distribuição na cidade. A partir do incêndio, diversas companhias privadas de água se estabeleceram, cada qual cuidando do fornecimento

193. RICHARDS, Henry Charles. London Water Supply: Being A Compendium Of The History, Law, \& Transactions Relating To The Metropolitan Water Companies From Earliest Times To The Present Day. London: P.S. King \& Son, 1989.

na página ao lado: Chicago 1857 (fonte: David Rumsey Map Collection) na página seguinte: Buenos Aires 1888 (fonte: David Rumsey Map Collection) 


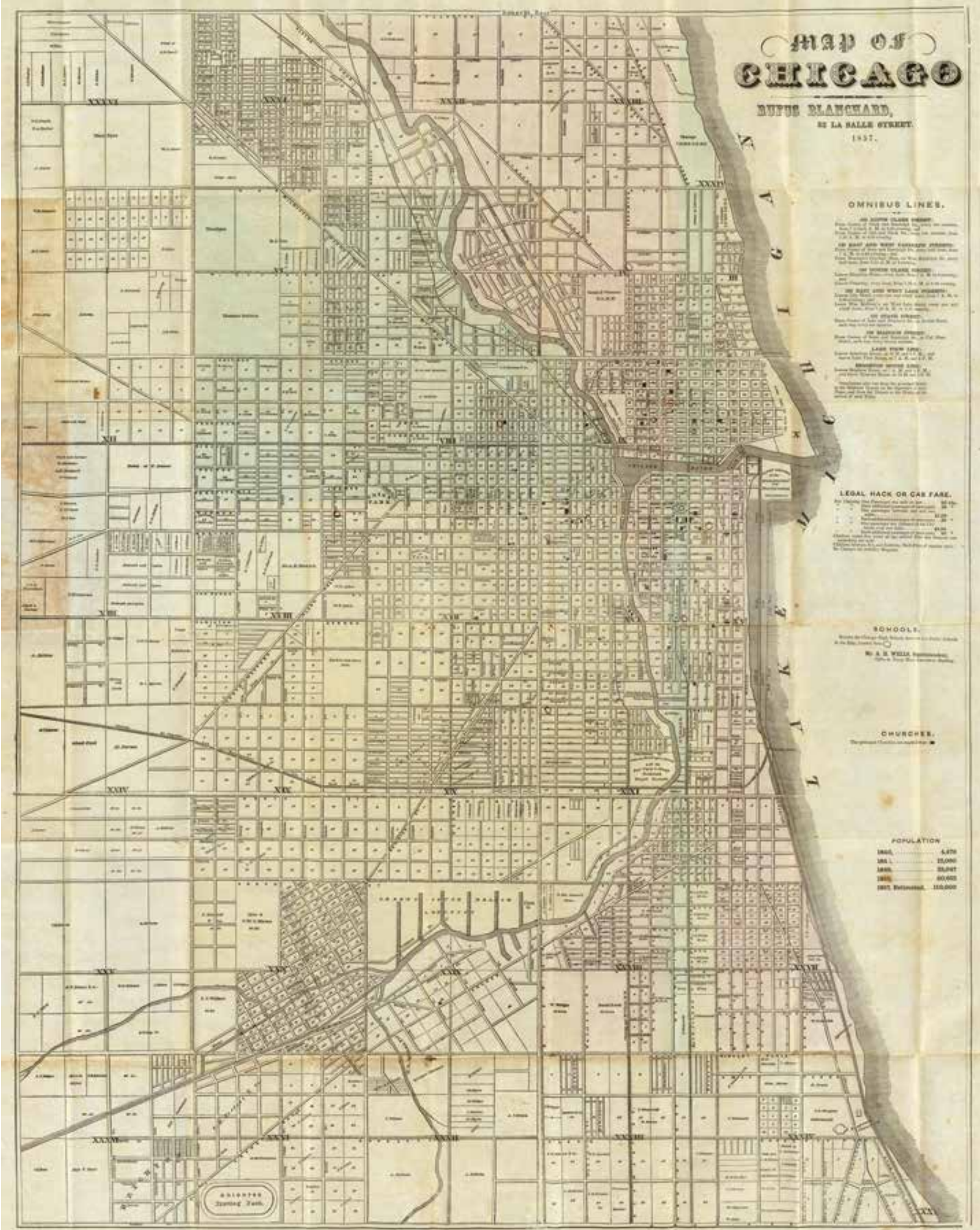




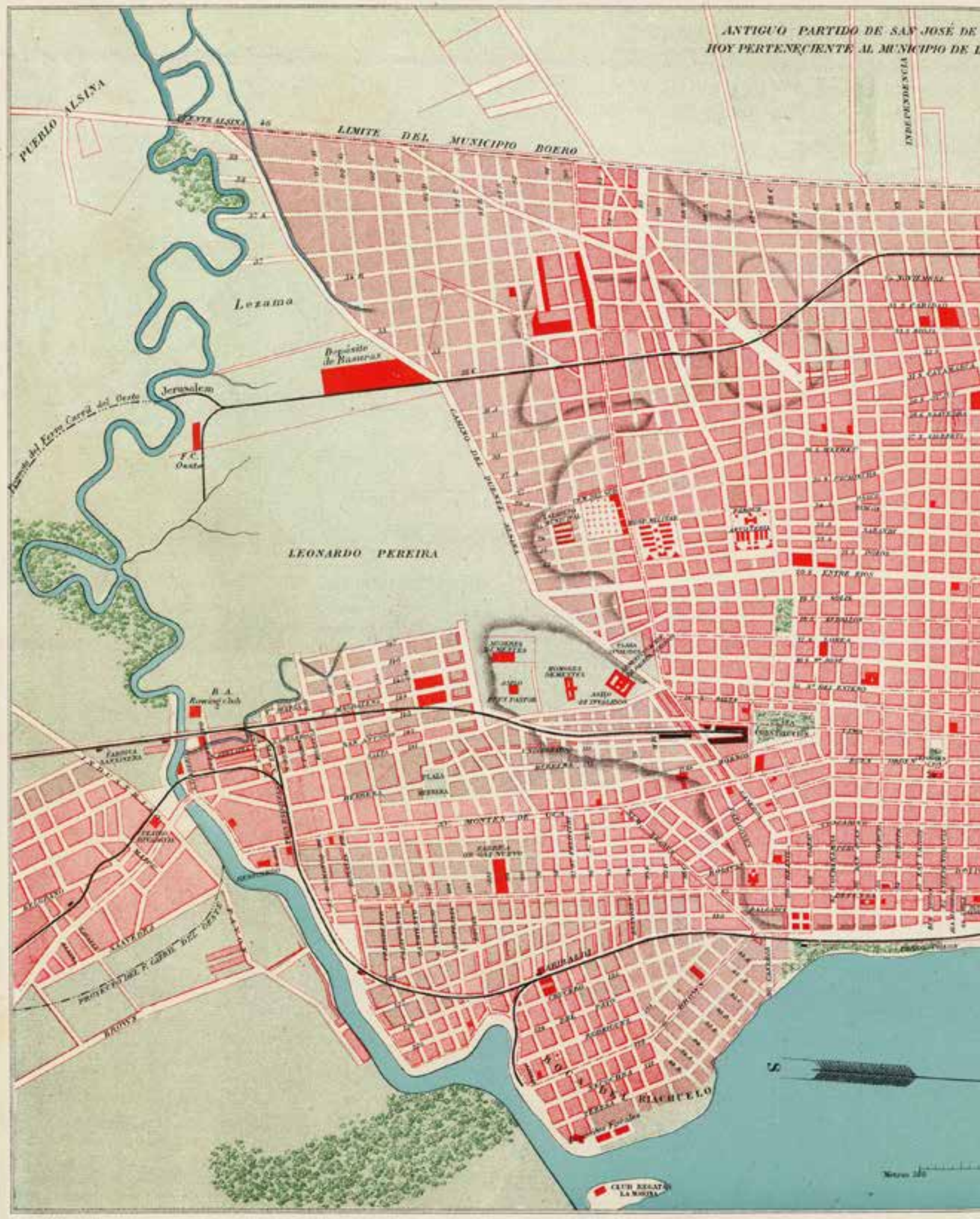




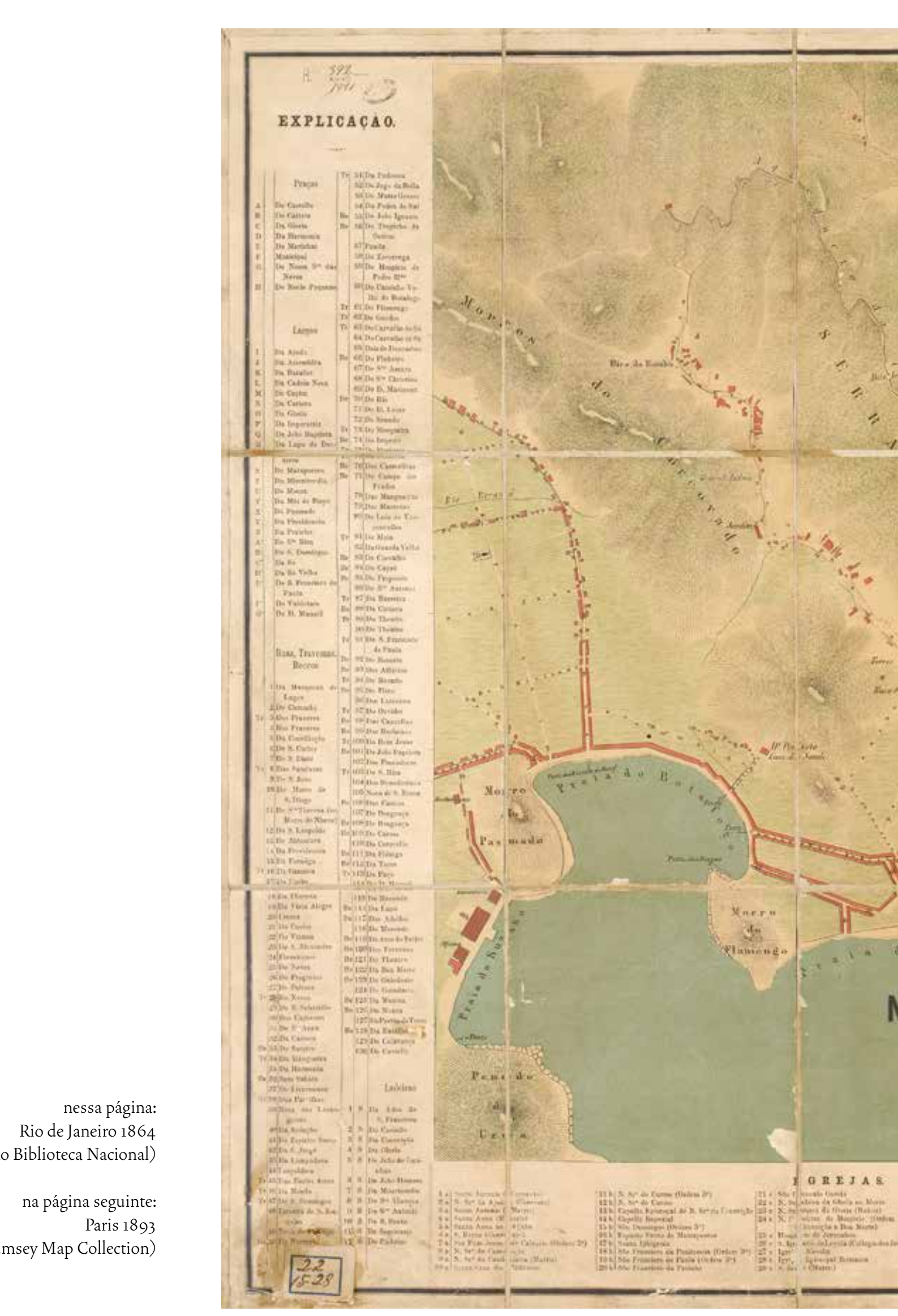




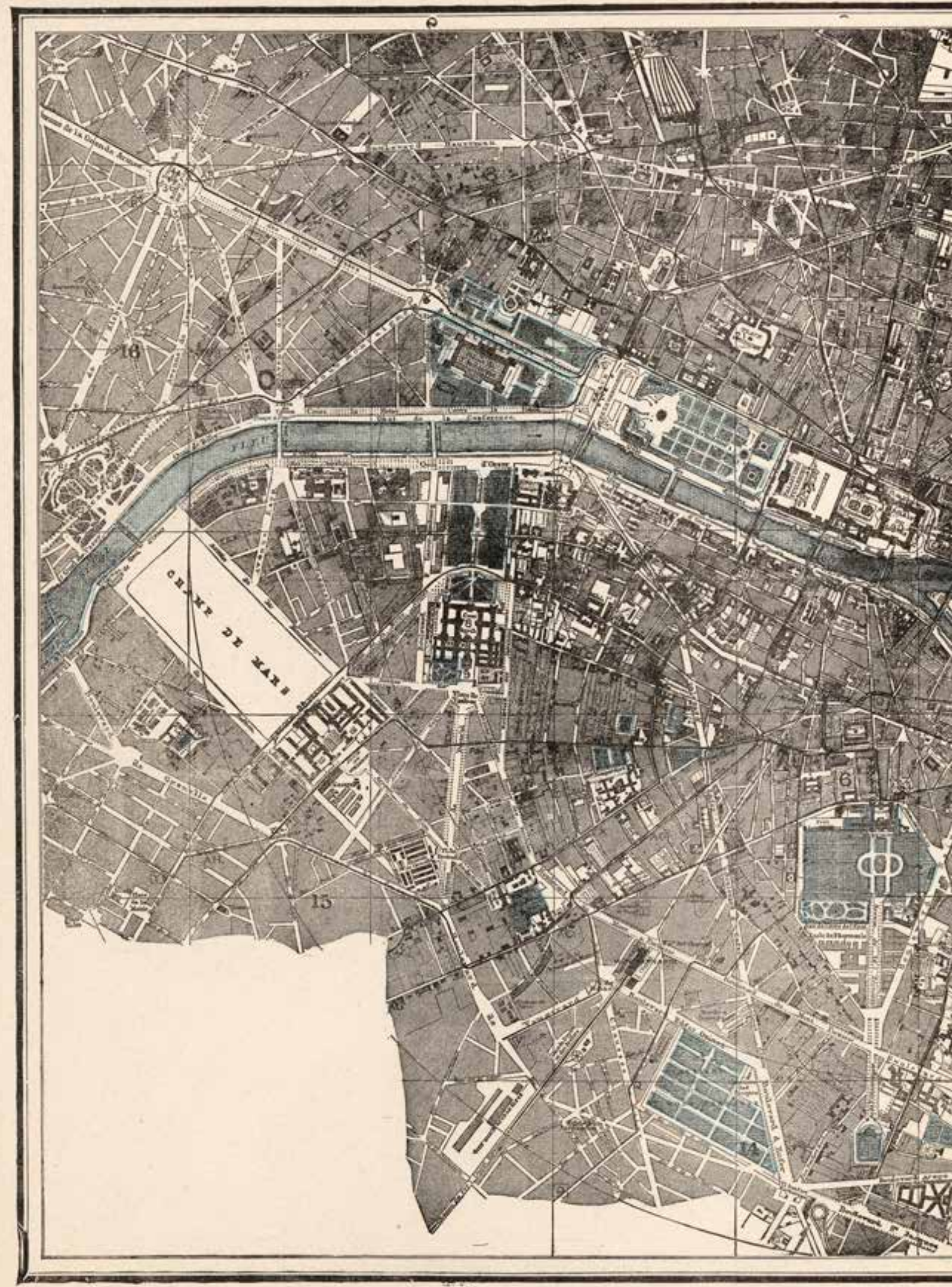




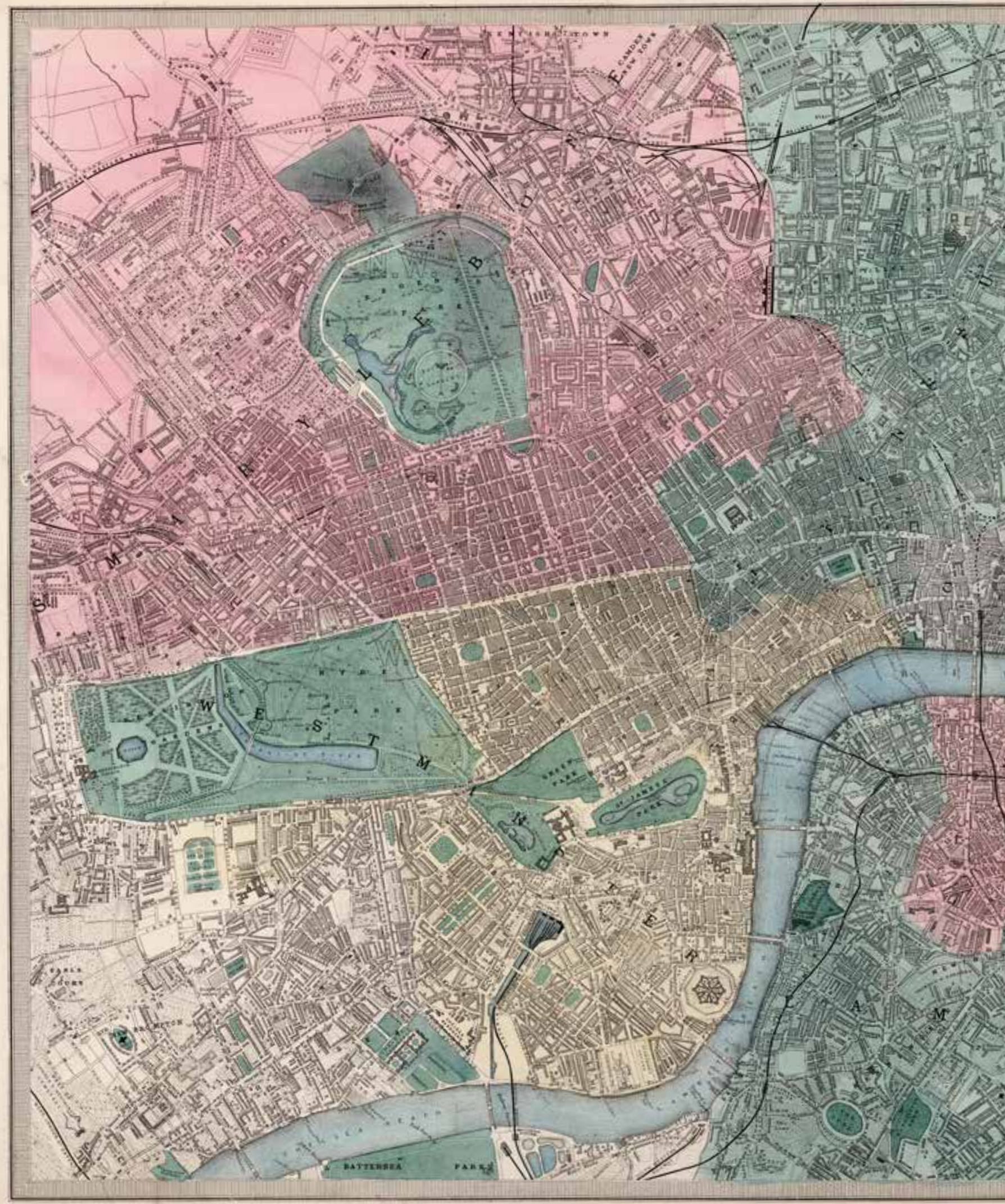




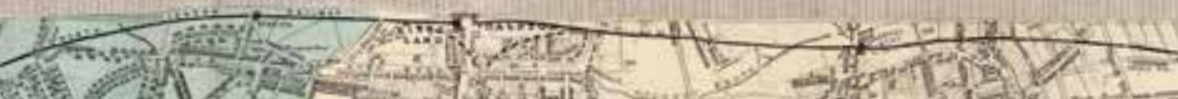

18 Fin

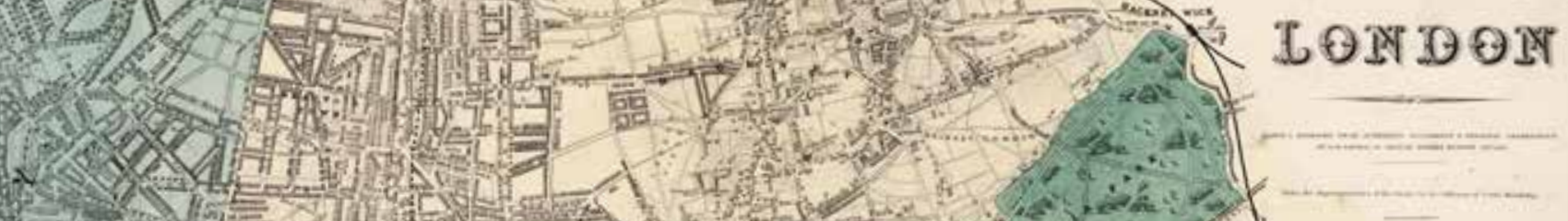

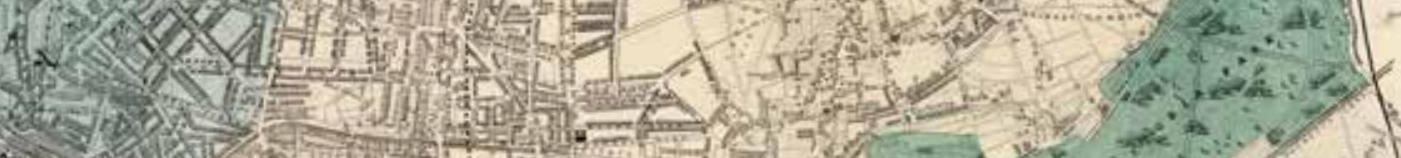

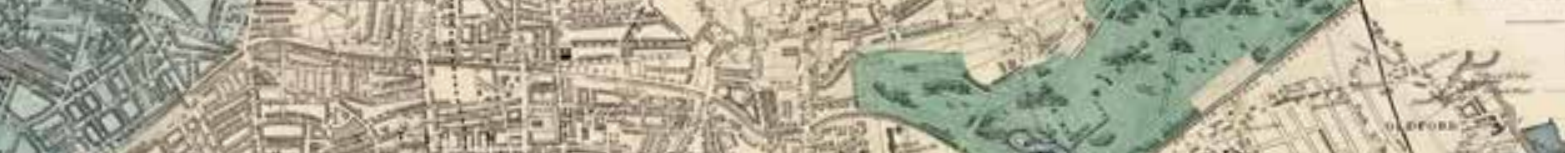
S. B r w 14. (a)

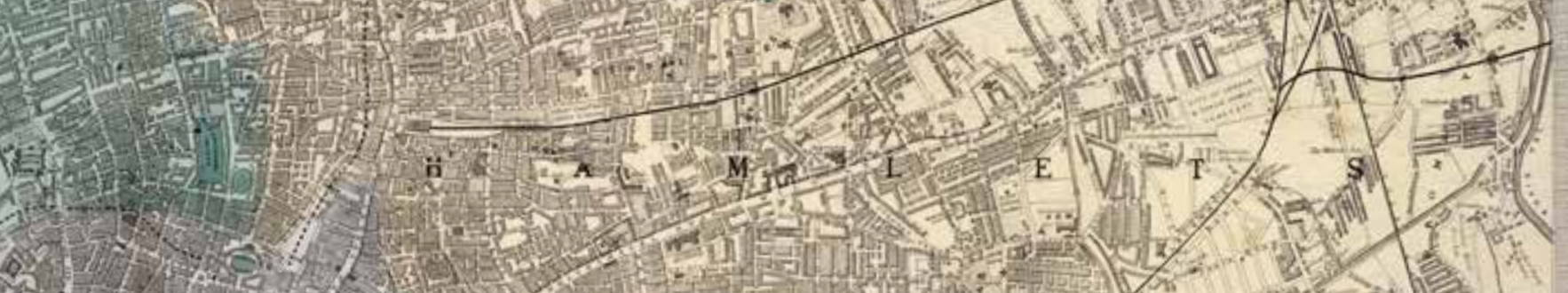
(2) 


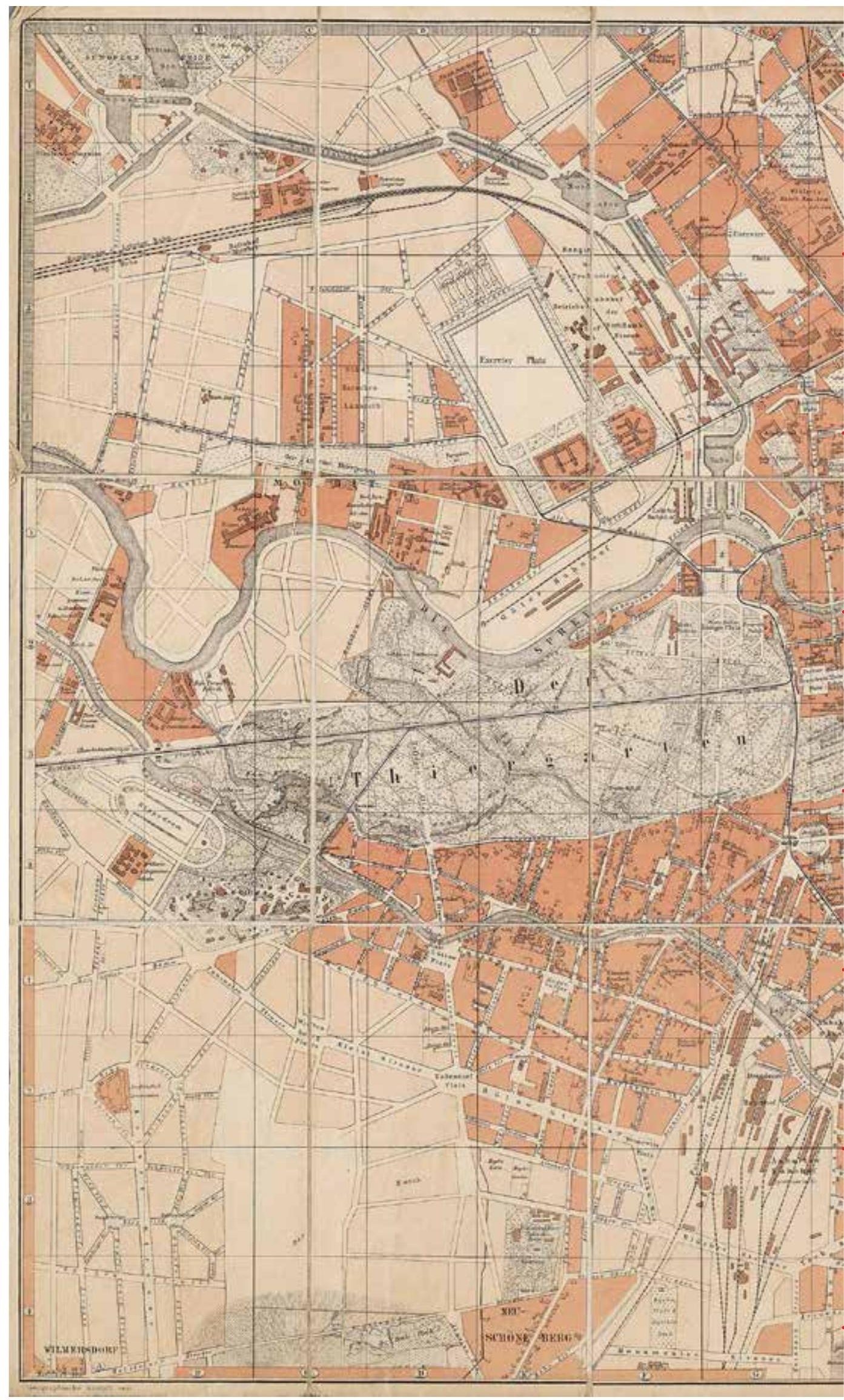


LETTS'S

POPULAR ATLAS.

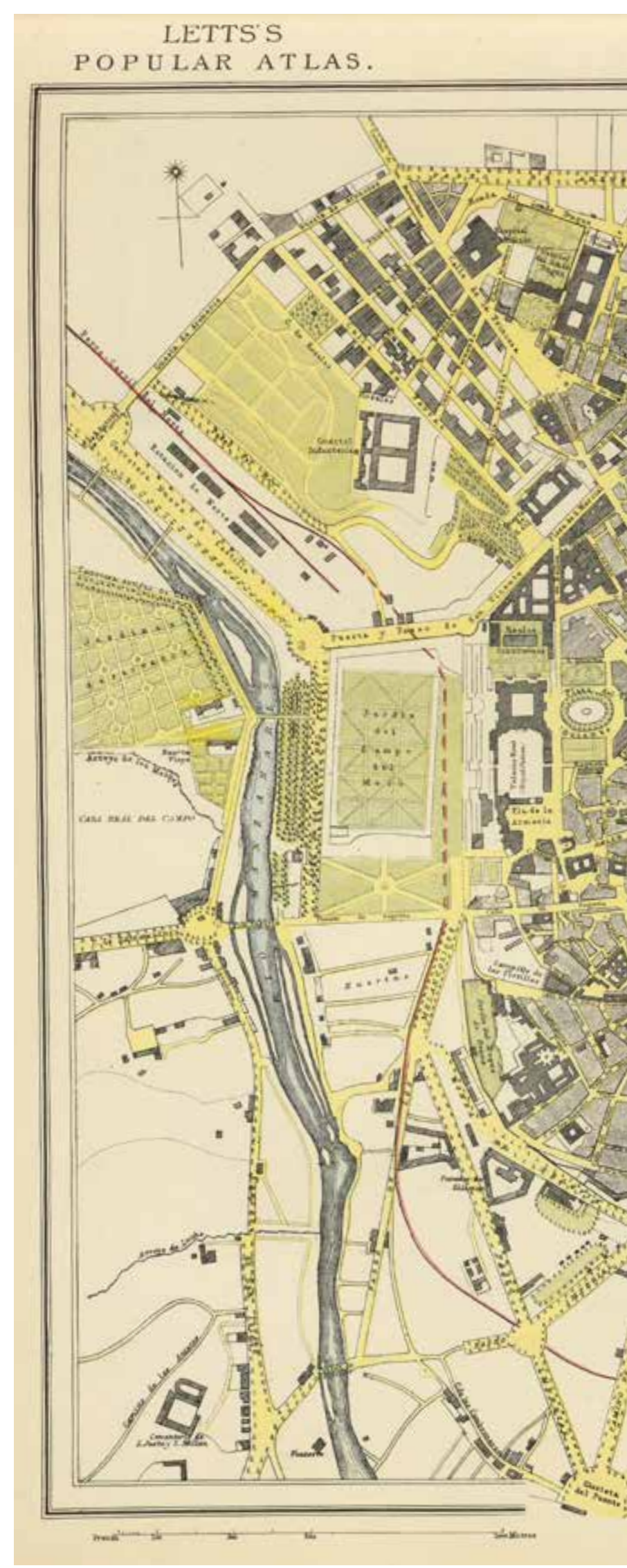

Madrid 1883

(fonte: David Rumsey Map Collection) 


\section{CITY OF MADRID.}
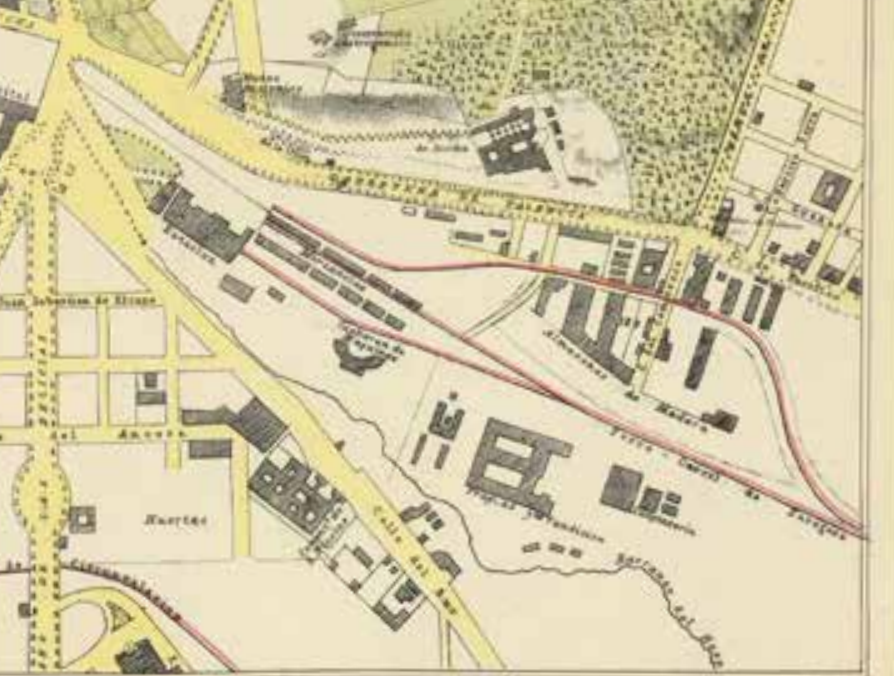
de uma porção da cidade. As empresas eram formadas assim que bairros novos e loteamentos se constituíam, acompanhando o crescimento da cidade. Essas empresas utilizavam água do rio Tâmisa e outros rios próximos que, já no início do século XIX, eram insuficientes e muito poluídos. O sistema de esgoto era inexistente, e o Tâmisa era considerado um esgoto a céu aberto. A legislação específica previa a competição entre as empresas, mas o que acontecia de fato eram acordos comerciais com respeito às divisões geográficas de atuação da companhias, estimulando a fusão entre essas empresas. Durante o século XIX, os efeitos da Revolução Industrial promoveram o crescimento da produção agrícola e $\mathrm{da}$ atividade industrial, momento em que Londres registra um espantoso crescimento do tecido urbano, passando, a população, de cerca de 880.000 habitantes em 1801, para cerca de 2.000 .000 em 1851. Nesse período foram registrados diversos surtos de cólera e epidemias, fazendo com que fosse declarada a Metropolis Water Act em 1852. A filtragem das águas dos rios próximos de Londres, que já era praticada por algumas empresas desde 1829, tornou-se obrigatória e a Comissão Metropolitana de Esgotos foi constituída. (RICHARDS, 1989)

O problema do esgoto permanecia negligenciado devido à falta de recursos. Foi somente em 1858, após um grave surto de mau cheiro em Londres, conhecido como The Great Stink, que o parlamento decidiu criar um sistema de esgotamento. O engenheiro Joseph Bazalguette projetou uma extensa rede subterrânea de coleta de esgotos que conduzia os dejetos até o estuário do Tâmisa, à jusante das áreas de maior densidade populacional. Até o final do século, diversos reservatórios de água foram construídos na cidade, abrangendo, o fornecimento, mais de $95 \%$ dos domicílios londrinos em 1900. No início do século XX, todas as empresas de fornecimento de água foram nacionalizadas a partir do $\mathrm{Me}$ tropolis Water Act de 1902, criando o Conselho Metropolitano de Água. (RICHARDS, 1989)

No início do século XIX, Berlin passou por um forte crescimento da atividade industrial, chegando a 1850 com uma população de 420.000 habitantes. Em 1870, já com uma população de 800.000 habitantes, no entanto, as condições de saneamento da cidade eram consideradas as piores de toda Europa, quando o esgoto corria em valas descobertas pelas ruas. O fim de barreiras comerciais e indenizações pagas pela França após o fim da guerra franco prussiana em 1871 favoreceram a atividade 
comercial, industrial e da construção na cidade. Foi apenas nesse período, em 1874, após a guerra, quando Berlin foi declarada capital do Império Alemão, que a rede esgotos e distribuição de água foi instalada. ${ }^{194}$

Madrid foi fundada no século IX a partir de uma fortaleza muçulmana que protegia as rotas fluviais do rio Manzanares. $O$ início da ocupação foi marcado pela abundância de águas de córregos afluentes do Manzanares, fontes naturais e também de águas subterrâneas. O rio Manzanares foi pouco explorado no início da ocupação devido ao seu exíguo volume de água e pequeno desnível. Durante o período medieval, Madrid teve um grande crescimento populacional fazendo com que, já no século XIV, se estudasse a possibilidade de captação de água em mananciais mais distantes. Nos séculos XV e XVI, engenheiros muçulmanos construíram um elaborado sistema de captação de águas subterrâneas chamado Qanat. Essa rede abastecia poços e canais, conhecidos como viajes de agua, onde se podia acessar água potável. As fontes públicas de água eram abastecidas por essa rede, mas somente membros da aristocracia e ordens religiosas possuíam encanamentos diretamente em suas propriedades. Estima-se que, no início do século XVIII, 55\% da água eram destinados a 471 derivações particulares, enquanto que para o restante da população havia apenas 43 fontes públicas, forçando os moradores a armazenar água em depósitos e barris. Além disso, cerca de metade das fontes públicas eram de uso exclusivo de vendedores de água conhecidos como aguadores, o que gerava diversos conflitos. ${ }^{195}$

Com o crescimento da população no século XVIII, essa rede se mostrou insuficiente frente à demanda de água, além de ineficaz, causando diversas epidemias de cólera. Assim, surgiram os primeiros projetos de fornecimento de água e saneamento a partir da captação de água em diversos rios da região. No século XIX, a cidade passou por um forte desenvolvimento da atividade industrial. A partir da instalação de estradas de ferro, Madrid passou a ser o centro de uma rede produtiva, provocando intenso incremento da área urbanizada e forte crescimento da população. Para resolver o problema do abastecimento de água, o projeto do

194. JUUTI, Petri S. e KATKO, Tapio S. Water, Time and European Cities: History Matters for the Futures. Tampere University Press, 2005.

195. LAFFOND, José Carlos Rueda. El Agua en Madrid: Datos para la Historia de Canal de Isabel II - 1851-1930. Madrid: Universidad Complutense de Madrid, 1994. 
Canal de Isabel II foi colocado em prática. Trata-se de um canal de captação de água de cinco rios próximos da cidade, constituindo uma rede de canais, túneis e aquedutos, responsável por fornecer um enorme volume de água para Madrid. Esse mesmo projeto contemplava uma rede de esgotos constituída por canais subterrâneos, responsáveis por conduzir os dejetos a partir de águas pluviais. Nesse mesmo período, para a realização do projeto, o Conselho Municipal de Madrid se encarregou do serviço de fornecimento de água mediante um decreto real. As obras foram realizadas com muitas dificuldades, utilizando, inclusive, a mão de obra de presidiários. A obra, iniciada em 1851, foi realizada em etapas, sendo concluída apenas em 1907 e acompanhou o crescimento da população, que foi de cerca de 160.000 habitantes em 1842 para cerca de 600.000 em 1910. (LAFFOND, 1994)

Ainda que se saiba que existe uma infinidade de mediações históricas, geográficas, sociais e econômicas que esses brevíssimos relatos não dão conta de resolver e explicar, é possível chegar a algumas questões relativas à constituição das redes de água e esgoto nessas cidades.

A industrialização aconteceu nessas cidades em tempos diferentes e de formas distintas, mas a provisão dos sistemas de distribuição de água e esgotamento aconteceu simultaneamente, na segunda metade do século XIX. A simultaneidade da instalação das redes parece estar relacionada ao momento em que a produção de infraestruturas urbanas e a busca pela reprodução de capital a partir da provisão de serviços urbanos e condições gerais se mundializava. A acumulação de riqueza através da provisão das redes e serviços urbanos passava a ser buscada com mais efetividade, não importando para isso qual o estágio do desenvolvimento econômico da industrialização ou da história desses centros. Esse fenômeno é a acumulação através da produção do espaço. Dessa forma, é possível afirmar que a água se tornou mercadoria, quase que simultaneamente em todos esses centros, inclusive em São Paulo que, como vimos, ainda não tinha a importância econômica que teria nas décadas seguintes.

Entretanto, o espaço engendrado pela atividade industrial nessas cidades difere muito - ver mapas das páginas 191 a 202. Os mapas dessas cidades nesse período revelam que a relação com as águas dos rios é diferente em cada uma dessas cidades. Chicago, Buenos Aires e Rio de Janeiro são semelhantes quanto à relação com a água pois estão à beira 
de um lago, rio e mar, respectivamente. A presença de sua água não é passível de interferência pela urbanização, sendo transformados apenas pequenos rios e córregos.

Paris, Londres e Berlin são muito parecidas sobe esse aspecto, já que o núcleo urbano se desenvolve ao redor do rio, que divide a cidade em duas. O rio é englobado pelo núcleo urbano. No caso dessas três cidades, o rio permaneceu meândrico mesmo com a intensa urbanização de suas margens, muito provavelmente pelo ritmo em que se deu a sua ocupação.

Madrid é a cidade que mais se assemelha a São Paulo. O núcleo foi estabelecido em uma cota mais elevada em relação ao rio, ocupando a sua margem esquerda. Assim como São Paulo, o rio Manzanares parece ter constituído alguma barreira para o crescimento do tecido urbano. Ainda assim, é possível observar que, nas margens do rio Manzanares, existem, além de loteamentos, diversos espaços públicos, parques e praças, o que não acontece nas margens dos rios Tamanduateí, Tietê e Pinheiros, onde predomina amplamente a ocupação privada da terra através de loteamentos.

Os mapas dessas cidades devem ser comparados ao mapa de São Paulo de 1881 - páginas 146-147. O que diferencia o processo de incorporação dos rios de São Paulo e dessas outras cidades é o contexto em que o maior crescimento urbano aconteceu. A relação entre a explosão demográfica e a disponibilidade de terras livres para urbanização em São Paulo não encontra qualquer semelhança com qualquer uma das cidades citadas, apesar de haver alguns pontos em comum com todas elas. Certamente é São Paulo que apresenta a relação mais distante entre a cidade e os rios. A transformação de seus rios, terras e águas, de recursos naturais em recursos econômicos, aconteceu antes do período intenso de urbanização, certamente colaborando para que esses espaços fossem produzidos de acordo com os marcos do modo de produção capitalista, determinando como a natureza seria incorporada ao processo de reprodução de capital baseado, sobretudo, na produção do espaço. 


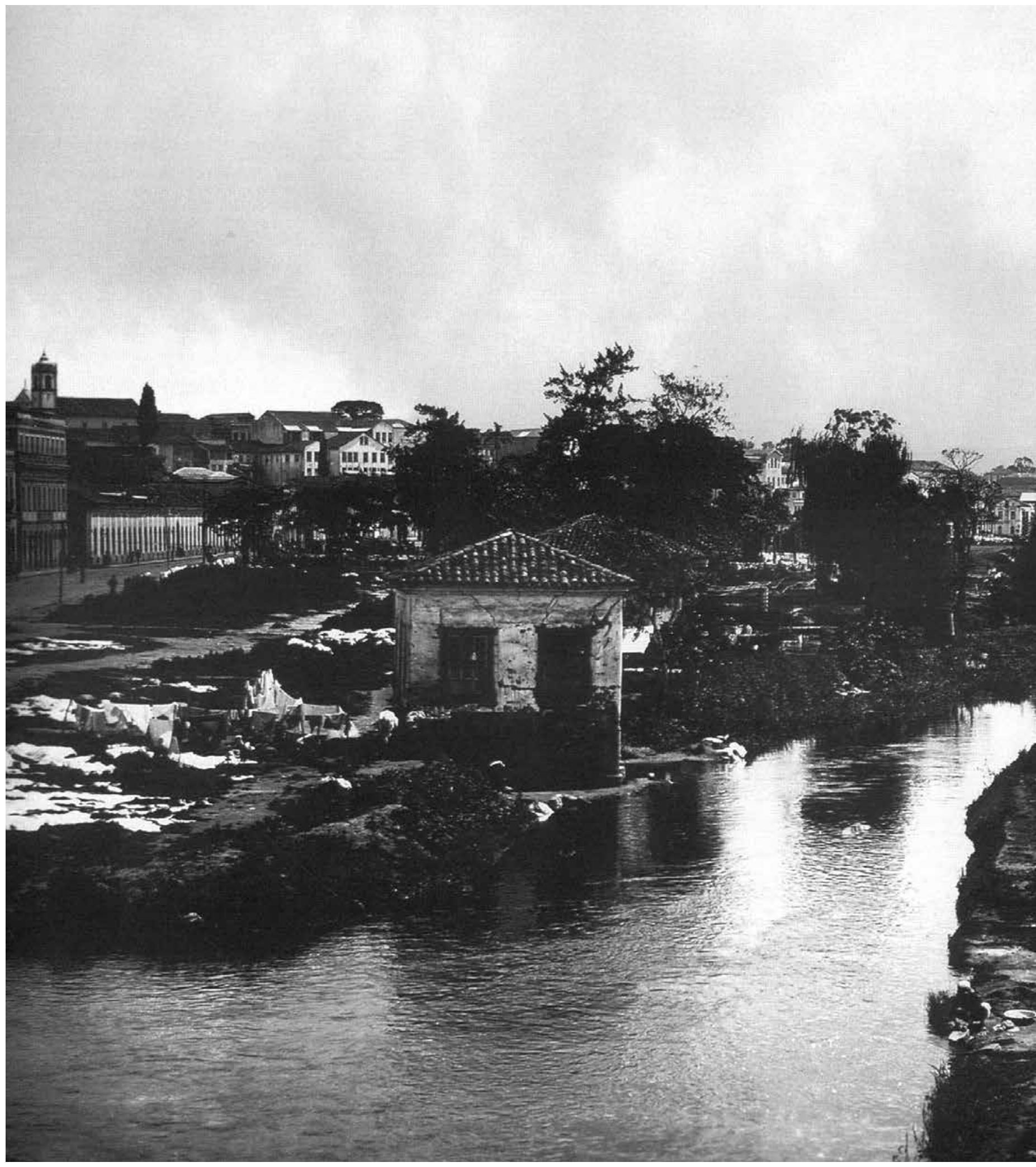




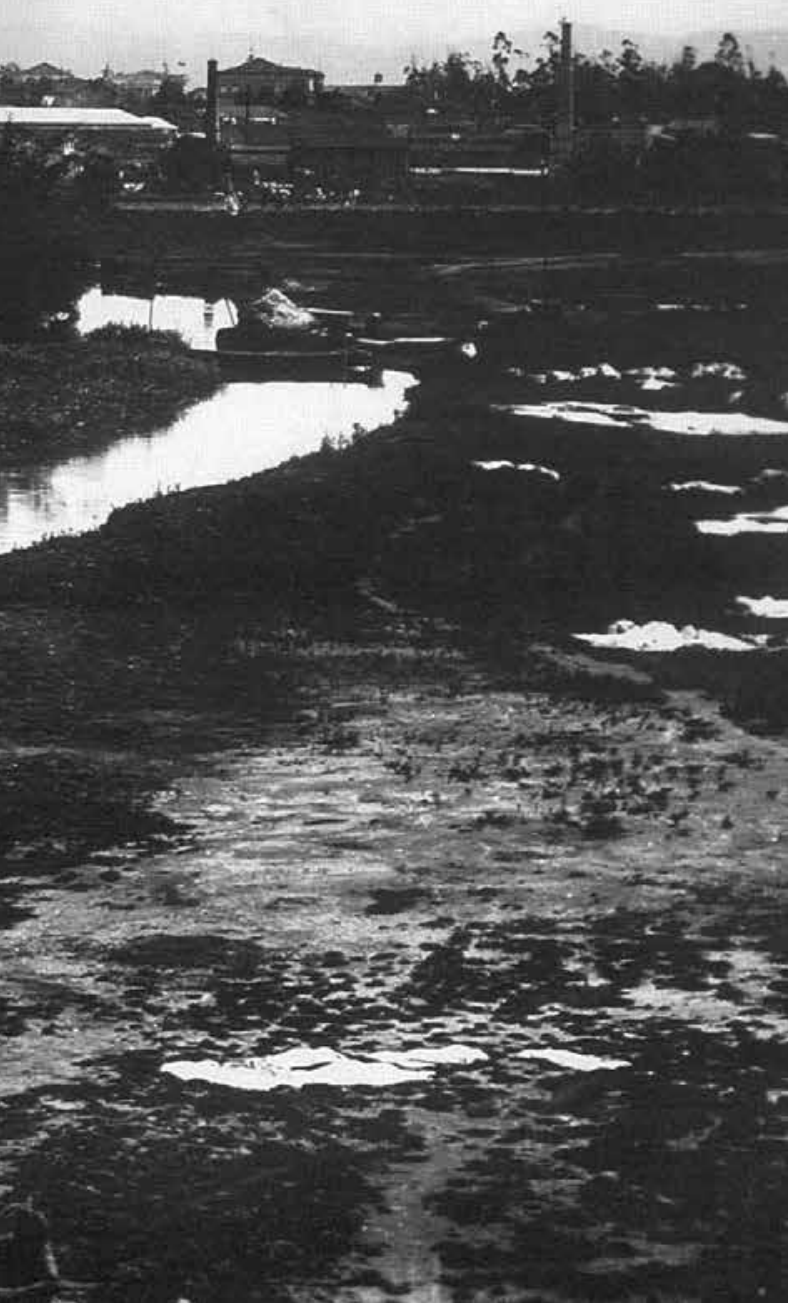

rio Tamanduateí 1890 foto: Guilherme Gaensly (fonte: Instituto Moreira Sales) 

CONCLUSÃO - O RIO TORNADO ÁGUA

Rios são terra e água.

O processo que transformou os rios de São Paulo é, sobretudo, um processo de abstração. Rios têm um lugar, um nome, uma fisionomia, características físicas e materiais. Por essa razão, são fortemente ligados ao chão e à terra, ou seja, à natureza primeira, à paisagem natural. Terra e água para beber, limpar, limpar-se, nadar, pescar e lavar roupas. Terra e água de onde se extrai materiais, lama, barro para fazer tijolos, areia e cascalho para construir e pavimentar. Terra e água das margens para plantar, engordar o boi, caçar, navegar e aportar. Terra e água que metabolizam os dejetos do homem. Todas atividades concretas. Terra e água que estruturam a vida do homem a partir do ritmo das suas cheias e vazantes. Rios concretos, usáveis, nomeáveis, determinados por suas especificidades qualitativas, das quais se faz uso, implicando terra e água.

Drenar as terras marginais e retificar seu canal é separar terra e água e submeter homem e natureza. É tornar os rios uma abstração-concreta na medida em que engendra e reproduz práticas sociais. É uma forma de deslocar o rio de suas possibilidades enquanto natureza primeira e enquanto unidade. É abstrair essas possibilidades enquanto potências relativas ao uso, reduzindo-as a mercadorias e matérias-primas, a elementos isolados: terra e água quando separados tornam-se divisíveis e quantificáveis. Terra e água caracterizados por designações técnico-cien- 
tífico-burocráticas, descritos por abstrações numéricas e representações: metros, metros cúbicos, litros, kilowatt/hora. A fragmentação dos rios e do próprio espaço, entre terra e água está relacionada à determinação econômica da propriedade, resultando na fragmentação da natureza, separada em partes, vendida aos pedaços, consumida em lotes e litros.

"Não existe nenhum "paraíso perdido", atenuar os efeitos dos fenômenos naturais sobre a vida, usar a natureza como força produtiva é uma conquista fundamental e que pertence a toda História pregressa da humanidade". ${ }^{196}$ (SEABRA, 1994, p.261)

O homem, na atividade social de buscar meios para sua subsistência, realiza trabalho, reproduz e produz sua existência agindo sobre a natureza, determinando usos para ela. A interação do homem com a natureza, interna e externa, produz a evolução social. $O$ ato de retirar algo da natureza, determinar um uso para uma parte dela, inclusive para o próprio corpo, é um ato de apropriação. ${ }^{197}$ A relação entre o homem e suas condições naturais está contida no conceito de propriedade, isto é, no ato de se apropriar, de tomar posse, da natureza. Dessa forma, a propriedade seria a relação do indivíduo com as condições "naturais" de trabalho e reprodução ${ }^{198}$.

Ao se apropriar da natureza, os homens constroem relações sociais e concepções que dão sentido à sua atividade, transformando, assim, a sociedade, que é a base de sua atuação na natureza. A especialização de funções é possibilitada pela produção de excedentes que, com a divisão social do trabalho, torna possível a troca. Inicialmente, a produção e a troca têm como finalidade apenas o uso, o consumo imediato, ou seja, a manutenção do produtor direto e de sua comunidade. A evolução social está justamente no processo de emancipação do homem com relação à natureza e seu crescente domínio sobre a mesma (MARX, 2006).

Esse movimento inclui um progressivo distanciamento entre trabalho e propriedade, na medida em que o homem se afasta das suas rela-

196. SEABRA, Odette C. De L., Os Meandros dos Rios nos Meandros do Poder: Tietê e Pinheiros - valorização das várzeas de São Paulo. Tese de doutoramento, FFLCH-DG/USP, São Paulo, 1994, p.261.

197. HOBSBAWM, Eric. Introdução, in MARX, Formações Econômicas Pré-Capitalistas, São Paulo: Paz e Terra, 2006, cit., p. 16.

198. MARX, Formações Econômicas Pré-Capitalistas, São Paulo: Paz e Terra, 2006, cit., p. 66. 
ções primitivas e espontâneas com a natureza. Essa evolução é marcada pelo processo de separação entre o trabalho livre e as condições objetivas para a sua realização, ou seja, a separação entre os meios de trabalho e o objeto de trabalho ${ }^{199}$.

A produção capitalista pressupõe a separação entre o trabalhador e a propriedade das condições de realização do trabalho. Essa separação, até certo ponto, natural, não somente é conservada, mas reproduzida em escala sempre crescente. Esse processo transforma, por um lado, os meios sociais de subsistência e produção em capital e, por outro, os produtores diretos em trabalhadores assalariados (MARX, 1985a).

Desta forma, no modo de produção capitalista, existe a necessidade de separar o produtor direto da terra e da água como a forma de sujeição do trabalhador. Essa ruptura da relação de propriedade entre produtor e meios de produção e subsistência, no modo capitalista, forma uma massa de trabalhadores livres obrigada a trocar a sua força de trabalho por dinheiro. Essa expropriação é a base do processo, pois, sem terras livres e sem a possibilidade de subsistência pela natureza, ela garante que o trabalhador não terá outra opção a não ser vender a sua força de traba-

199. "O ponto chave sobre a questão é: em todas estas formas nas quais a propriedade da terra e a agricultura constituem a base da ordem econômica, consequentemente, o objetivo econômico é a produção de valores de uso, isto é, a reprodução dos indivíduos em determinadas relações com sua comunidade, da qual constituem a base, encontramos os seguintes elementos: 1. Apropriação das condições naturais de trabalho: da terra como o instrumento original de trabalho, ao mesmo tempo laboratório e reservatório de matérias primas; entretanto, apropriação que se efetua não por meio do trabalho, mas como condição preliminar do trabalho. O indivíduo simplesmente, considera as condições objetivas de trabalho como próprias, como a natureza inorgânica de sua subjetividade, que se realiza através delas. A principal condição objetiva de trabalho, em si, não se mostra como o produto do trabalho mas ocorre como natureza. De um lado, temos o indivíduo vivo, do outro a terra como condição objetiva de sua reprodução. 2. A atitude em relação à terra, à terra como propriedade do indivíduo que trabalha, significa que o homem mostra-se, desde o princípio, como algo mais do que a abstração do "indivíduo que trabalha", tendo um modo objetivo de existência na propriedade da terra, que antecede sua atividade e não surge como simples consequência dela, sendo tanto uma pré-condição de sua atividade, como é sua própria pele, como são seus órgãos sensoriais, pois toda a pele, e todos os órgãos dos sentidos são, também, desenvolvidos, reproduzidos, etc, no processo da vida, quanto pressupostos desse processo de reprodução". (MARX, 2006, p.77-78) 


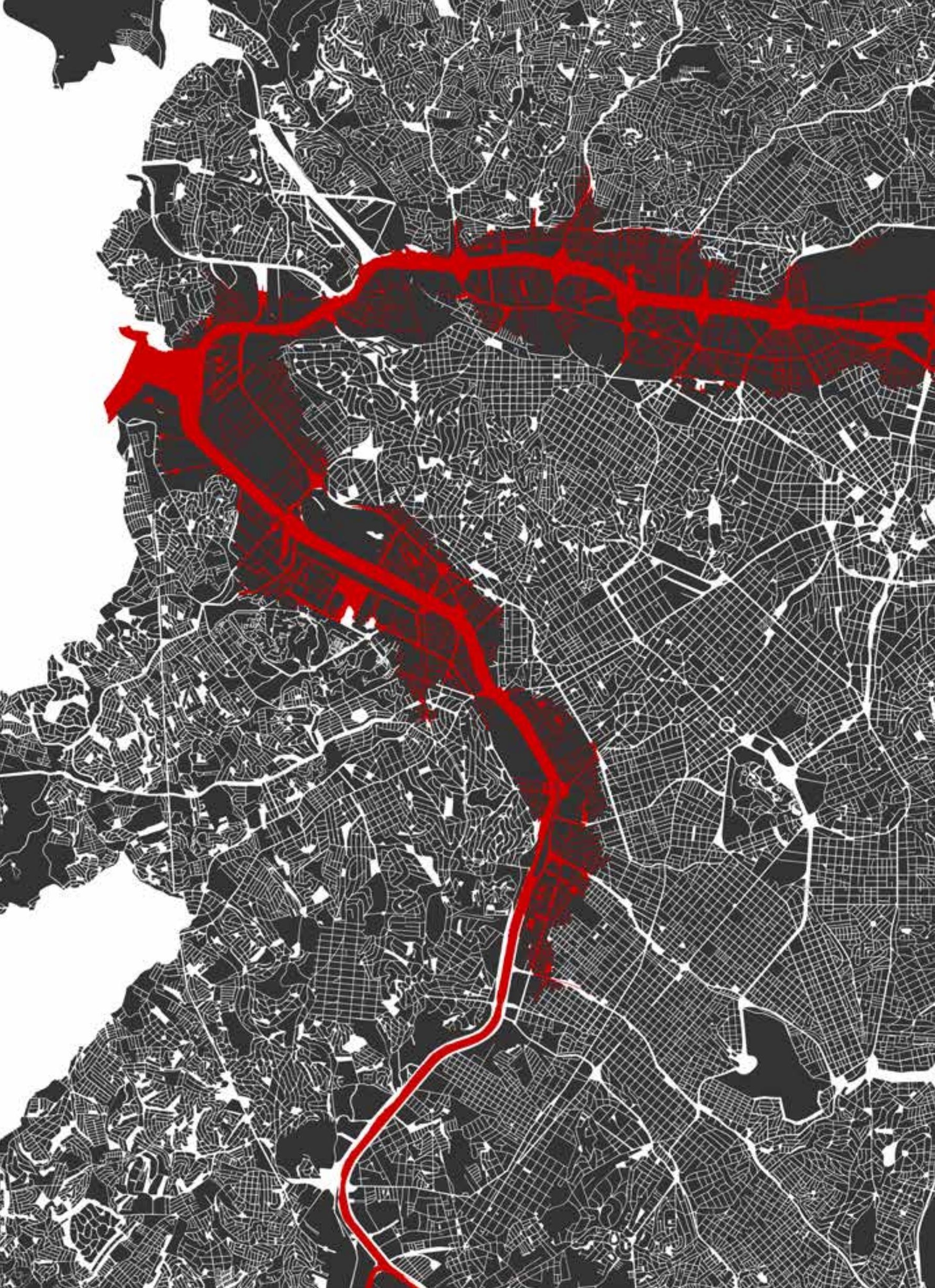





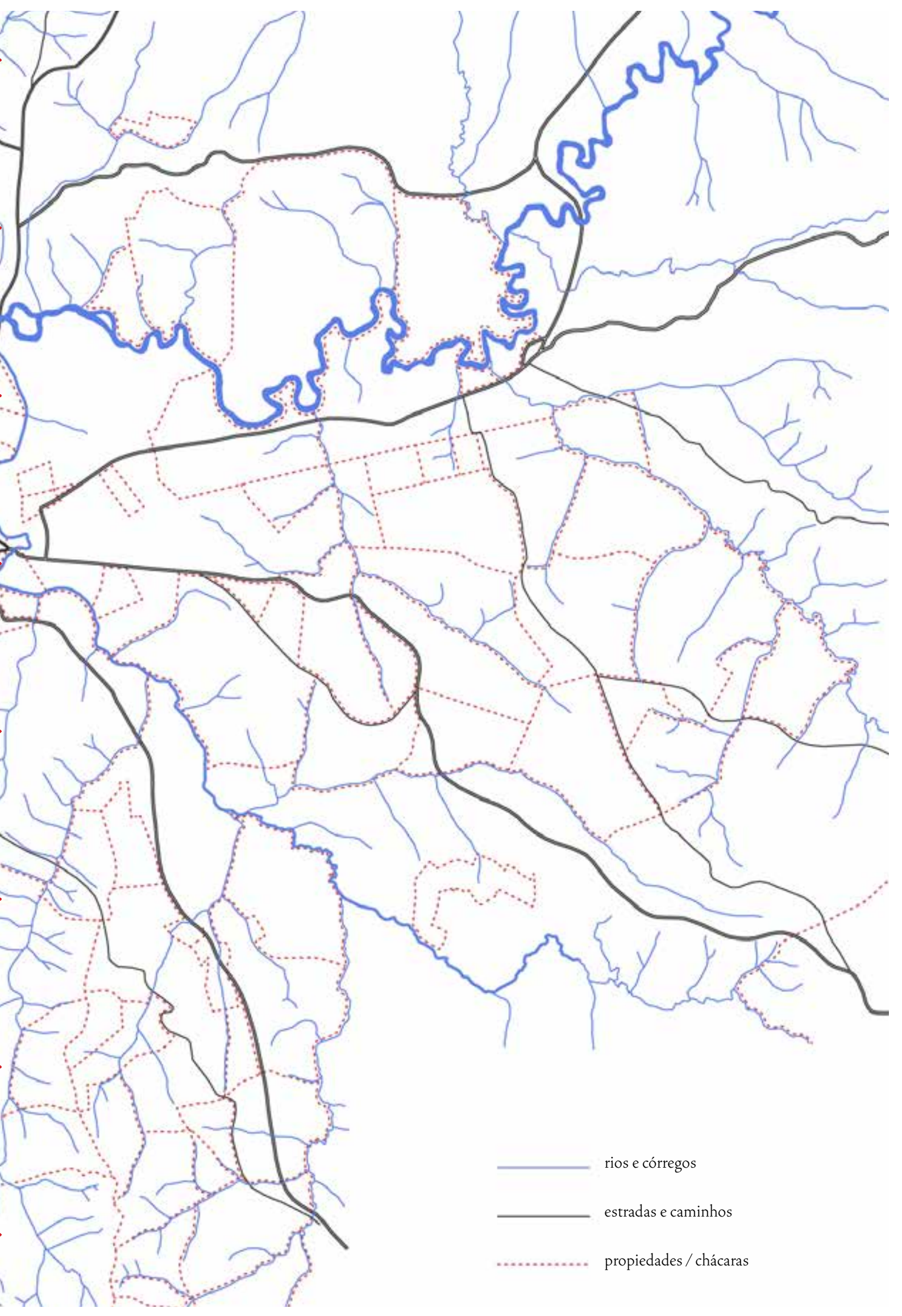





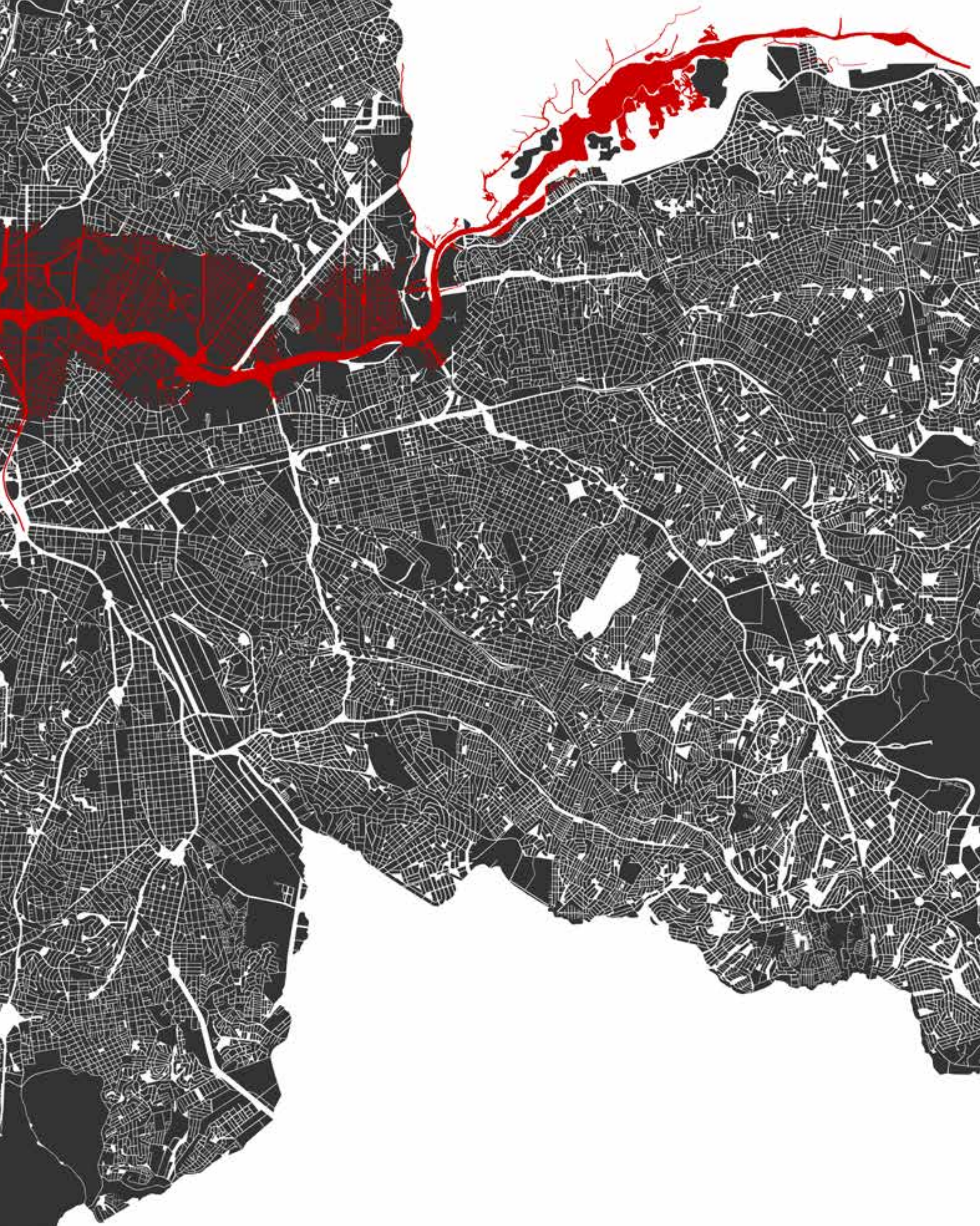


1ho. (MARX, 1985a) ${ }^{200}$. A natureza, portanto, participa do processo como força produtiva, como mercadoria, e também como forma de sujeição do trabalho ao capital.

"A crítica radical implicada no conceito de apropriação esclarece a propriedade, no limite, como não-apropriação, como paródia, como caricatura, como restrição à apropriação concreta. Isso se dá porque a apropriação está referenciada a qualidades, atributos, ao passo que a propriedade está referenciada a quantidades, a comparações quantitativas, igualações formais, ao dinheiro (que delimitando o uso tende a restringi-lo) ${ }^{201}$

No caso dos rios de São Paulo, desde a fundação da vila, dentro da lógica de exploração colonial, ainda que fossem considerados um bem comum, já apareciam submetidos às formas de apropriação privada da natureza. A atividade direta e imediata de subsistência através dos rios conviveu com a intermediação de trabalho cativo, onde o produtor direto é alienado dos meios de produção, determinando, assim, que as terras e as águas dos rios já se manifestassem como um produto do trabalho.

Durante o período colonial, os rios próximos da cidade estavam submetidos à condição de apropriação das terras de uso comum, o rocio, por nelas estarem contidos, definindo assim a forma com que terra $e$ água seriam apropriadas.

Através da intermediação do trabalho e do desenvolvimento de re-

200. "Esse modo de produção pressupõe o parcelamento do solo e dos demais meios de produção. Assim como a concentração destes últimos, exclui também a cooperação, divisão do trabalho dentro dos próprios processos de produção, dominação social e regulação da Natureza, livre desenvolvimento das forças sociais produtivas. Ele só é compatível com estreitas barreiras naturalmente desenvolvidas da produção e da sociedade. [...] Sua destruição, a transformação dos meios de produção individuais e parcelados em socialmente concentrados, portanto da propriedade minúscula de muitos em propriedade gigantesca de poucos, portanto a expropiação da grande massa da população de sua base fundiária, de seus meios de subsistência e instrumentos de trabalho, essa terrível e difícil expropriação da massa do povo constitui a pré-história do capital. [...] A propriedade privada obtida com trabalho próprio, baseada, por assim dizer, na fusão do trabalhador individual isolado e independente com suas condições de trabalho, é deslocada pela propriedade privada capitalista, a qual se baseia na exploração do trabalho alheio, mas formalmente livre." (MARX, 1985a, p.379380)

201. SEABRA, Odette C. De L. A Insurreição do uso, in MARTINS, José de Sousa. Henri Lefebvre e o Retorno à Dialética. Hucitec, 1996. 
lações de produção, o uso dos rios passou a conviver com o "valor" dos rios, que se desdobra em valor de uso e o valor de troca. A relação contraditória que envolvia a vila e os rios aparece na provisão dos primeiros sistemas de distribuição de água e na relação entre a mão de obra utilizada nessas construções e a finalidade dos trabalhos.

As contradições presentes no ato de apropriação privada e utilização econômica de recursos essenciais à vida aparecem em São Paulo quase que simultaneamente ao momento de fundação da vila, e se evidenciam nos séculos seguintes diante da precariedade dos sistemas de distribuição e despejos, da escassez e da qualidade da água de que se serviam os moradores.

A poluição dos rios, isto é, o ato de, conscientemente, depredar as águas que se consome, como foi visto, era um costume indígena anterior à fundação da vila, não sendo, portanto, uma característica somente do colonizador. Entretanto, ela ganha escala e volume com o crescimento da população, evidenciando as contradições e a incapacidade de lidar com os dejetos produzidos pelos próprios moradores.

A falta de água, como foi dito, está longe de ser uma condição natural de São Paulo. Pelo contrário, a escassez é um fato social, constituída paralelamente ao processo de valorização econômica da terra e da água.

A obtenção de renda, através de atividades realizadas nos rios por trabalho livre, foi uma oportunidade criada pela falta de água e pelo fato de os rios próximos ao núcleo já estarem poluídos. Apesar de não ter introduzido grandes transformações nas relações sociais e econômicas da vila, essas rendas de subsistência passaram a refletir algum avanço na divisão do trabalho e consequente afastamento entre o produtor direto e os meios de produção. No caso dessas atividades, os meios de produção, isto é, terra e água, permaneciam sob o domínio do produtor direto. Desse modo, a relação entre o trabalho e a propriedade dos meios de realização desse trabalho era relativamente íntegra.

"Liberado, o princípio da propriedade privada não permanece estéril; ele engendra um espaço. [...] Dominando o espaço (mais exatamente submetendo-o ao dominium), o princípio da propriedade punha fim à contemplação da natureza, cosmos ou mundo, para exibir a via da ação dominadora, que transforma ao invés de interpretar." 202

202. LEFEBVRE, Henri. La Presencia y La Ausencia: Contribuición a La Teoria de las 
Durante o século XIX, a cultura do café e a política de importação de mão de obra contribuíram para que o capital antes investido na propriedade do escravo passasse a ser empregado na propriedade fundiária, ou seja, no espaço, implicando transformações no modo de apropriação da terra e da água. Na cidade, a acumulação de capital baseada na produção de condições gerais através da provisão de infraestruturas urbanas passa a integrar uma esfera mundial de reprodução do capital, representado pela presença de capital estrangeiro nas companhias de serviços públicos, sendo financiadas por bancos sediados em outros países. A produção do espaço como um processo mundial de acumulação se manifesta na simultaneidade com que as redes de infraestrutura de água e esgoto são estabelecidas em diversas cidades do mundo. No caso de São Paulo, o capital investido, em geral, era estrangeiro e as operações eram controladas e assessoradas pelas elites nacionais, evidenciando que essa acumulação acontecia pela associação e pelo alinhamento de interesses entre essas partes.

A expropriação dos espaços de uso comum, que é o meio para a acumulação de capital, incorporou os rios a partir da valorização econômica da terra e da água. Essas áreas foram utilizadas como a base material da produção do espaço de São Paulo. A transformação de terra e água em recursos econômicos e sua mercantilização aconteceu simultaneamente em diversas cidades, resultando em processos de urbanização distintos e em diferentes formas de permanência dos espaços comuns, atualmente considerados simplesmente públicos. O momento em que aconteceu essa acumulação, através da produção do espaço e da provisão de infraestruturas e serviços urbanos, distingue o processo ocorrido em São Paulo daquele nos demais centros. Do ponto de vista da estruturação espacial da cidade, esse processo se deu no momento em que o núcleo urbanizado era muito restrito, praticamente confinado ao triângulo histórico original, estando a maior parte das áreas que abrigariam a atual metrópole, desocupadas, ainda que tivessem proprietários. Os rios, já bastante poluídos, estavam nessas áreas, estando, portanto, submetidos à lógica de produção do espaço e à racionalidade da reprodução do capital, determinando a forma como esses espaços e, sobretudo, terra e água, seriam apropriados e urbanizados. A sobreposição de mapas das páginas 214 a 219 mostra como o processo de alienação do patrimônio 
comum foi a base material do processo de produção do espaço. Essa sobreposição mostra que o espaço-capital concentrado em chácaras permaneceu na forma dos loteamentos que constituiu o tecido urbano. Os rios, separados em terra e água, desapareceram como natureza e passam a integrar as redes de drenagem, esgotamento e produção de eletricidade.

A partir destas reflexões, esta pesquisa colabora para a ampliação da compreensão do processo de urbanização de São Paulo, destacando o papel dos rios, e das transformações empreendidas, como importantes estruturadores da metrópole, constituindo-se como base material da produção do espaço e também determinadores das formas de apropriação da natureza e do homem. 

AB'SABER, Aziz Nacib. Geomorfologia do Sítio Urbano de São Paulo. São Paulo, tese de doutoramento, FFCL USP, 1957.

AMERICANO, Jorge. São Paulo naquele tempo. São Paulo: Saraiva, 1957. ARASAWA, Cláudio Hiro. Engenharia e poder: Construtores da nova ordem em São Paulo (1890-1940). São Paulo: Alameda, 2008.

AZEVEDO, Aroldo de (org.) Associação dos Geógrafos Brasileiros, Cidade de São Paulo: estudo de geografia urbana, São Paulo: Nacional, 1958.

BARAVELLI, José Eduardo. Trabalho e tecnologia no programa MCMV. São Paulo: Tese de Doutoramento, FAUUSP, 2014.

BARLES, S. Urban metabolism and river systems: an historical perspective - Paris and the Seine, 1790-1970. Hydrology and Earth System Sciences, 2007.

BARTALINI, Vladimir. Os córregos ocultos e a rede de espaços públicos urbanos, in Arquitextos: vitruvius, São Paulo, 2009.

BOURDIEU, Pierre. O Poder Simbólico. Rio de Janeiro: Bertrand Brasil, 2007.

BRANCO, Catullo. “Enchentes em São Paulo.” In: História \& Energia. São Paulo: Departamento de Patrimônio Histórico da Eletropaulo/ Eletropaulo, 1995.

BRITO, Monica Silveira. A Participação da Iniciativa Privada na Produção do Espaço Urbano: São Paulo 1890-1911. Dissertação de Mes- 
trado apresentada ao Departamento de Geografia da FFLCH-USP, 2000.

BRITO, Mônica Silveira. Modernização e tradição: urbanização, propriedade da terra e crédito hipotecário em São Paulo na segunda metade do século XIX. 2007. Tese de Doutorado apresentada ao Departamento de Geografia da FFLCH-USP, 2007.

BRUNO, Ernani Silva. História e Tradições da cidade de São Paulo: vol.1 Arraial de Sertanistas (1554-1828). São Paulo: Hucitec, 1991.

BRUNO, Ernani Silva. História e Tradições da cidade de São Paulo:vol.2 Burgo de Estudantes (1828-1872). São Paulo: Hucitec, 1991.

BRUNO, Ernani Silva. História e Tradições da cidade de São Paulo: vol.3 Metrópole do Café (1872-1918)/São Paulo de Agora (1919-1954). São Paulo: Hucitec/PMSP, 1984.

BUENO, Beatriz Piccolotto Siqueira. Aspectos do Mercado Imobiliário em Perspectiva Histórica: São Paulo 1809-1950. São Paulo: FAUUSP, 2008.

BUENO, Beatriz Piccolotto Siqueira. Aspectos do Mercado Imobiliário em Perspectiva Histórica: São Paulo 1809-1950. São Paulo: FAUUSP, 2008.

BUENO, Beatriz Piccolotto Siqueira. Desenhando o Brasil: o Saber Cartográfico dos Cosmógrafos e Engenheiros Militares da América Portuguesa e do Brasil Império. In: COSTA, Antônio Gilberto. (Org.). Roteiro Prático de Cartografia: da América Portuguesa ao Brasil Império. Belo Horizonte: FUNDEP/UFMG, 2007, v. , p. 29-49.

CAMPOS, Cristina de. A promoção e a produção das redes de água e esgotos na cidade de São Paulo, 1875-1892. São Paulo: Anais do Museu Paulista: História e Cultuta Material, 2005.

CAMPOS, Eudes. Arquitetura paulistana sob o Império. Aspectos da formação da cultura burguesa em São Paulo, Tese de Doutorado FAUUSP, 1997.

CAMPOS, Eudes. São Paulo Antigo: Plantas da Cidade. Imformativo Arquivo Histórico Municipal, 4 (20): set/out. 2008.

CASTELAN, Márcio José. Da Produção do Espaço Urbano aos Meios de Consumo Coletivo: Articulando-os para o Debate. Presidente Prudente: Mimeo, s/d.

CERQUEIRA, Carlos Gutierrez. Tebas - Vida e Atuação na São Paulo Colonial. IPHAN/SP, 2011.

COSTA, Emília Viotti da. Da senzala à Colônia. São Paulo. Difel, 1982.

DAMIANI, Amelia Luisa . A propósito do espaço e do urbano: algumas 
hipóteses. Cidades, Presidente Prudente, São Paulo, v. 1, n. 1, p. 79-95, 2004.

DAMIANI, Amelia Luisa . A Metrópole e a Industria: reflexões sobre uma urbanização crítica. Revista Terra Livre, São Paulo, v. 15, p. 21-37, 2000.

DEAK, Csaba e SCHIFFER, Sueli Ramos (orgs,). "O Processo de Urbanização no Brasil". Edusp, São Paulo, 1999.

DIAS, Maria Odila L. da S. Quotidiano e poder em São Paulo no século XIX. São Paulo: Brasiliense, 1995.

DICK, Maria Vicentina de Paula do Amaral, A Dinâmica dos Nomes na Cidade de São Paulo 1554 - 1897. São Paulo, Annablume, 1996.

FERNANDES, Florestan. A Revolução Burguesa no Brasil. Ensaio de interpretação sociológica. Rio de Janeiro: Zahar, 1975.

FERRARA, Luciana. Urbanização da natureza: da autoprovisão de infraestruturas aos projetos de recuperação ambiental nos mananciais do sul da metrópole paulistana. São Paulo: Tese de Doutoramento, FAUUSP, 2013.

FOLIN, Marino. La Ciudad del Capital y Otros Escritos, Barcelona: Gustavo Gili, 1976.

FERNANDES, Florestan. A Integração do Negro na Sociedade de Classes. São Paulo: Ática, 1978.

FRANCO, Fernando de Mello. A Construção do Caminho: A estruturação da metrópole pela conformação técnica das várzeas e planícies da Bacia de São Paulo. São Paulo: Tese de Doutoramento, FAUUSP, 2005.

FREHSE, Fraya. O tempo das ruas de São Paulo de fins do Império. São Paulo: Edusp, 2005.

FREITAS, Affonso A. de Freitas. Tradições e Reminiscências Paulistanas. São Paulo: Itatiaia/Edusp, 1985.

GASPAR, Byron. Fontes e Chafarizes de São Paulo. São Paulo: Conselho Estadual de Cultura, 1970.

GEORGE, Pierre. O Meio Ambiente. São Paulo: Difusão Européia do Livro, 1973.

GLEZER, Raquel. Chão de terra: um estudo sobre São Paulo colonial. São Paulo: Livre Docência, FFLCH-USP, 1992.

GOTTDIENER, Mark. A produção social do espaço. São Paulo, Edusp, 1993.

GOUVÊA, José Paulo Neves. A Urbanização de Santo Amaro e o Largo Treze de Maio. São Paulo: Trabalho Final de Graduação, FAUUSP, 
2004.

GOUVÊA, José Paulo Neves. Cidade do Mapa: A Produção do Espaço de São Paulo através de suas Representações Cartográficas. São Paulo: Dissertação de Mestrado, FAUUSP, 2010.

HARVEY, David. A Produção Capitalista do Espaço. São Paulo, Annablume, 2005 .

HARVEY, David. O enigma do capital e as crises do capitalismo. São Paulo: Boitempo, 2011.

HOBSBAWM, Eric. Introdução, in MARX, Formações Econômicas Pré-Capitalistas, São Paulo: Paz e Terra, 2006.

HOLANDA, Sérgio Buarque de, Raízes do Brasil. São Paulo: Companhia das Letras, 1995.

IDOETA, Ivan V.; CINTRA, Jorge P. São Paulo vista do alto, 75 anos de aerofotogrametria. São Paulo: Érica, 2004.

JARAMILLO, Samuel. Hacia una teoría de la renta del suelo urbano. Bogotá: Universidad de los Andes. Facultad de Economia, CEDE, Ed. Uniandes, 2010.

JORGE, Janes. Tietê: o rio que a cidade perdeu, São Paulo, 1890 - 1940. São Paulo: Alamenda, 2006.

JUUTI, Petri S. e KATKO, Tapio S. Water, Time and European Cities: History Matters for the Futures. Tampere University Press, 2005.

KAHTOUNI, Saide. Cidade das Águas. São Paulo: Rima, 2004.

KOWARICK, Lúcio. Escritos urbanos. São Paulo: Editora 34, 2000.

LAFFOND, José Carlos Rueda. El Agua en Madrid: Datos para la Historia de Canal de Isabel II - 1851-1930. Madrid: Universidad Complutense de Madrid, 1994.

LANGENBUCH, Jurgen Richard. A estruturação da Grande São Paulo: estudo de geografia urbana. São Paulo, Biblioteca Geográfica Brasileira, 1971.

LEFEBVRE, Henri. A Produção do Espaço. prefácio da edição francesa de 1974, tradução de Jorge Hajime Oseki, mimeo, 2007.

LEFEBVRE, Henri. O Direito à Cidade. São Paulo: Editora Documentos, 1969.

LEFEBVRE, Henri. A Revolução Urbana. Belo Horizonte: Editora UFMG, 1999.

LEFEBVRE, Henri. La Presencia y La Ausencia: Contribuición a La Teoria de las Representaciones. México D.F.: Fondo de Cultura Econonica, 2006.

LEONEL, Mauro. A Morte Social dos Rios. São Paulo: Perspectiva, 1998. 
MADRE DE DEUS, Frei Gaspar da. Memórias para a História da Capitania de São Vicente. São Paulo: EDUSP, 1975.

MARTINS, Antônio Egídio. São Paulo antigo. Secretaria de Cultura, Esporte e Turismo, São Paulo, s/d.

MARTINS, José de Souza (org.). Henri Lefebvre e o retorno à dialética. São Paulo: Hucitec, 1996.

MARTINS, José de Souza. O cativeiro da terra, São Paulo: Livraria Editora Ciências Humanas, 1981.

MARX, Karl. O Capital: Crítica da Economia Política, vol.ı Livro Primeiro: O Processo de Produção do Capital, Tomo 1. São Paulo: Abril Cultural, 1985 a.

MARX, Karl. O Capital: Crítica da Economia Política, vol.ı Livro Primeiro: O Processo de Produção do Capital, Tomo 2. São Paulo: Abril Cultural, $1985 \mathrm{~b}$.

MARX, Karl. O Capital: Crítica da Economia Política, vol.3 Livro Terceiro: O Processo Global da Produção Capitalista, Tomo 2. São Paulo: Abril Cultural, 1986.

MARX, Karl, Manuscritos econômicos-filosóficos, São Paulo: Boitempo, 2004.

MARX, Karl. Formações Econômicas Pré-Capitalistas, São Paulo: Paz e Terra, 2006.

MARX, Murillo. Cidade no Brasil terra de quem? São Paulo: Nobel/ Edusp, 1991.

MATTES, Delmar. O Espaço das Águas: as várzeas de inundação na cidade de São Paulo. São Paulo: dissertação de mestrado, FAUUSP, 2001.

MESGRAVIS, Laima. Afonso de Escragnolle de Taunay, o historiador de São Paulo in TAUNAY, Afonso de Escragnolle. São Paulo nos primeiros anos: 1554-1601. São Paulo no século XVI. São Paulo: Paz e Terra, 2007.

MÔNACO, Roberto. As terras devolutas e o crescimento da cidade de São Paulo. Dissertação de Mestrado FAUUSP, São Paulo, 1991.

MOREIRA, Renata Maria Pinto. Distribuição de água na região metropolitana de São Paulo: tecnologias da universalização e produção do espaço. São Paulo: Dissertação de Mestrado, FAUUSP, 2008.

MORSE, Richard. Formação histórica de São Paulo: De comunidade a metrópole. São Paulo: Difusão Européia do Livro, 1970.

OSEKI, Jorge H. e MAUTNER, Yvonne M. M., 'O espaço das redes de serviços em São Paulo" p.13-20, in Sinopses 20, FAUUSP, São Paulo 1993. 
OSEKI, Jorge H., "A fluvialidade no Rio Pinheiros: um projeto de estudo", in Revista Pós n. 8 - a Pós Graduação da FAUUSP nos 500 anos do Brasil - Szmrecsanyi, M. I. (coord.), p. 171-177, São Paulo 2000.

OSEKI, Jorge H.." Depoimento", in Revista Caramelo Extra - "Maharishi SP Tower" - p. 28-29, FAUUSP, São Paulo 1999.

OSEKI, Jorge e ESTEVAM, Adriano Ricardo. A fluvialidade em rios paulistas, in COSTA, Lucia Maria Sá Antunes (org.). Rios e Paisagens Urbanas: em Cidades Brasileiras. p. 77-94. Rio de Janeiro: Vianna \& Mosley: Editora Prourb, 2006.

OSEKI, Jorge H. O Único e o Homogêneo na Produção do Espaço in MARTINS, José de Souza (org.). Henri Lefebvre e o retorno á dialética, São Paulo: Hucitec, 1996.

OSEKI, Jorge H.. Pensar e Viver a Construcao da Cidade: Canteiros de Desenhos de Pavimentação, Drenagem de Águas Pluviais e Redes de Esgoto em São Paulo. Tese de doutoramento, FAUUSP, São Paulo 1992.

PASSOS, Maria Lúcia Perrone e EMÍDIO, Teresa. Desenhando São Paulo: Mapas e Literatura: 1877-1954. São Paulo, Ed. Senac São Paulo: Imprensa Oficial, 2009.

PEREIRA, Paulo Cesar Xavier. São Paulo - a construção da cidade - 18721914. São Carlos, Rima, 2004.

PEREIRA, Paulo Cesar Xavier. Espaço, técnica e construção. São Paulo: Nobel, 1988.

PEREIRA, Paulo Cesar Xavier. A Modernização de São Paulo no Final do Século XIX: da demolição da cidade de taipa à sua reconstrução com tijolos. in: Habitação e Cidade. São Paulo: FAUUSP/FAPESP, 1998.

PETRELLA, Guilherme Moreira. Das fronteiras do conjunto ao conjunto das fronteiras. São Paulo: Dissertação de Mestrado, FAUUSP, 2009.

PETRONE, Pasquale. "São Paulo no século XX". In: Aroldo de Azevedo (dir.). A cidade de São Paulo. Estudos de geografia urbana. São Paulo: Companhia Editora Nacional, Brasiliana, 1958.

PETRONE, Pasquale. Aldeamentos Paulistas. São Paulo: Edusp, 1995.

PIRES, Walter. Arquivo Aguirra. Fonte documental sobre a formação territorial de São Paulo. in Anais do Museu Paulista. São Paulo. 10/11 p.61-78, 2002.

PORTA, Paula. História da Cidade de São Paulo, vol.ı: A cidade Colonial. São Paulo: Paz e Terra, 2004.

PORTA, Paula. História da Cidade de São Paulo, vol.2: A cidade no Império. São Paulo: Paz e Terra, 2004. 
PORTA, Paula. História da Cidade de São Paulo, vol. 3: A cidade na primeira metade do século XX. São Paulo: Paz e Terra, 2004.

PRADO JÚNIOR, Caio, A cidade de São Paulo: geografia e história / Caio Prado Jr. Coleção: Tudo é História. São Paulo: Brasiliense, 1998.

RAFFARD, Henrique. Alguns dias na Paulicéia. São Paulo: Biblioteca Academia Paulista de Letras, 1977.

REIS FILHO, Nestor Goulart. São Paulo: Vila Cidade Metrópole. Prefeitura de São Paulo, 2004.

RICHARDS, Henry Charles. London Water Supply: Being A Compendium Of The History, Law, \& Transactions Relating To The Metropolitan Water Companies From Earliest Times To The Present Day. London: P.S. King \& Son, 1989.

ROCHA, Angela Maria. Espaço público e apropriação do espaço: notas sobre a evolução histórica de São Paulo. São Paulo,:Mimeo, 1995.

ROLNIK, Raquel. A Cidade e a Lei: legislação, política urbana e territórios na cidade de São Paulo, São Paulo: Studio Nobel: Fapesp, 2003.

RÜCKERT, Fabiano Quadros. Experiências de Saneamento na Cidade de Buenos Aires: dos projetos de Pellegrini a conclusão do Projeto Bateman (1829-1905). Florianópolis: Revista Esboços, 2013.

SAES, Fláivio A. M. de. A grande empresa de serviços públicos na economia cafeeira, 1850-1930. São Paulo: Hucitec, 1986.

SAINT-HILAIRE, Auguste de. Viagem à província de São Paulo. São Paulo: Martins/Edusp, 1972.

SANTA RITTA, José de. A Água do Rio: do Carioca ao Guandu.Rio de Janeiro: Synergia, 2009.

SANT'ANNA, Denise Bernuzzi. Cidade das Águas: usos de rios, córregos, bicas e chafarizes em São Paulo (1822-1901). São Paulo: Editora Senac, 2007.

SANT'ANNA, Denise Bernuzzi. "Vida e morte dos chafarizes na cidade de São Paulo:' In: Revista do Arquivo Municipal. São Paulo: Departamento do Patrimônio Histórico, vol. 203, 2004.

SANT'ANNA, Nuto. Metrópole. São Paulo: Coleção Departamento de Cultura, 1953.

SANTOS, Carlos José Ferreira dos. Várzea do Carmo: Lavadeiras, caipiras e "pretos véios". in Memória e Energia. São Paulo: Fundação Patrimônio Histórico da Energia de São Paulo, nro. 27, 2000.

SANTOS, Fábio Alexandre dos. "As epidemias no rastro das linhas férrreas". In: Arquivo. Rio Claro: Arquivo Histórico do Município de Rio Claro "Oscar de Arruda Penteado", 2002. 
SANTOS, Fábio Alexandre dos. Domando Águas, Salubridade e ocupação do espaço na cidade de São Paulo, 1875 - 1930. São Paulo: Alameda, 2011.

SEABRA, Odette C. De L. A Insurreição do uso, in MARTINS, José de Sousa. Henri Lefebvre e o Retorno à Dialética. Hucitec, 1996.

SEABRA, Odette C. De L., Os Meandros dos Rios nos Meandros do Poder: Tietê e Pinheiros - valorização das várzeas de São Paulo. Tese de doutoramento, FFLCH-DG/USP, São Paulo, 1994.

SEABRA, Odette C. de L.. Urbanização: bairro e vida de bairro, in Travessia São Paulo n. 38 p. 11-17, 2000.

SENNE, Catia Alves de. O papel do Serviço Sanitário na implantação de sistemas de abastecimento de água e de coleta de esgotos no Estado de São Paulo (1892-1902). São Paulo: Seminário Nacional de História da Ciência e da Tecnologia, 2012.

SESSO JR., Geraldo, Retalhos da Velha São Paulo. São Paulo: Gráfica Municipal de São Paulo, 1983.

SILVA, Elmo Rodrigues da. O curso da água na história: simbologia, moralidade e a gestão de recursos hídricos. Rio de Janeiro: Tese de Doutoramento, Escola Nacional de Saúde Pública, Fundação Oswaldo Cruz, 1998.

SILVA, José Ribeiro da. Os esgotos da cidade do Rio de Janeiro: 18571947. Rio de Janeiro: CEDAE, 1988.

SIMÕES JR, José Geraldo. Anhangabaú: história e urbanismo. São Paulo: Senac/Imprensa Oficial do Estado de São Paulo, 2004.

SIMONI, Lúcia Noemia. O arruamento de terras e o processo de formação do espaço urbano no Município de São Paulo: 1840-1930. São Paulo, Tese de Doutorado FAUUSP, 2002.

SLOTERDIJK, Peter. Esferas II (Globos). Biblioteca de Ensayo Siruela: Madrid, 2011.

SMITH, Carl. City Water, City Life: Water and the Infrastructure of Ideas in Urbanizing Philadelphia, Boston, and Chicago. University of Chicago Press, 2013.

TAUNAY, Affonso de E. História da cidade de São Paulo. Melhoramentos, 1953.

TAUNAY, Afonso de Escragnolle. São Paulo nos primeiros anos: 15541601. São Paulo no século XVI. São Paulo: Paz e Terra, 2007.

TOLEDO, Benedito Lima de. São Paulo: três cidades em um século. São Paulo: Cosac Naify, 2004.

TONE, Beatriz Bezerra. São Paulo, Século XXI: Valorização Imobiliária 
e Dissolução Urbana. São Paulo: Tese de Doutoramento, FAUUSP, 2015.

VICTORINO, Valério Igor. Luz e poder na dramática conquista do meio natural: A privatização dos rios paulistanos e a reflexividade sócio-ambiental. São Paulo: Tese de Doutoramento, FFLCH USP, 2002 a.

VICTORINO, Valério Igor. Uma visão Histórica dos Recursos Hídricos na Cidade de São Paulo in Revista Brasileira de Recursos Hídricos, vol. 7. São Paulo: 2002 b. 

ool. Rio Tamanduateí, 1910, Vicenzo Pastore, Instituto Moreira Sales. pg.32.

002. Rio Tamanduateí, 1910, Vicenzo Pastore, Instituto Moreira Sales. pg. 33 .

003. Secção do Tamanduatehy, 1893 , Commissão de Saneamento do Estado de São Paulo. pg.34-35.

004. Planta do Rio Tieté, 1926, Serviço Geográphico Militar. pg.36-37. 005. Mappa Topográphico do Município de São Paulo - folha 37, 1930, São Paulo, Município e Sara Brasil S/A. pg.38-39.

oo6. Planta da Cidade de São Paulo, 2016, José Paulo Gouvêa. pg.40-41 e pg.2014-219.

007. Planta da Cidade de São Paulo, 2016, José Paulo Gouvêa. pg.42-43. 008. Rede de Drenagem da Região de São Paulo, 1957, Aziz Nacib Ab'Saber. pg.56.

009. São Paulo de Piratininga em 1560, Affonso de Freitas. pg.58.

o10. Carta da Capital de São Paulo, 1842, João Jacques da Costa Ourique.pg.142-143.

o11. Mappa da Cidade de São Paulo, 1844/47, Karl Abrahan Bresser. pg.144-145.

012. Planta da Cidade de São Paulo, 1881, Companhia Cantareira e Esgotos. pg.146-147.

013. Planta da Cidade de São Paulo, 1883(4), Jorge Secker. pg.148-149.

014. Planta da Cidade de São Paulo, s/d, Repartição de Águas e Esgotos. pg.150-151.

015. São Paulo, s/d, Museu Paulista. pg.152-153.

o16. São Paulo, s/d, José Paulo Gouvêa. pg.154-155 e pg.216-217.

017. Chicago, 1857, David Rumsey Map Collection. pg.191.

o18. Buenos Aires, 1888, David Rumsey Map Collection. pg.192-193.

O19. Rio de Janeiro, 1864, David Rumsey Map Collection. pg.194-195.

020. Paris, 1893, David Rumsey Map Collection. pg.196-197.

021. Londres, 1865, David Rumsey Map Collection. pg.198-199.

022. Berlin, 1877, David Rumsey Map Collection. pg.200-201.

023. Madrid, 1883, David Rumsey Map Collection. pg.202-203.

024. Rio Tamanduateí, 1890, Guilherme Gaensly, Instituto Moreira Sales.pg.208-209. 




